1986

\title{
Neither heroine nor fool : Anna Ella Carroll of Maryland
}

Janet L. Coryell

College of William \& Mary - Arts \& Sciences

Follow this and additional works at: https://scholarworks.wm.edu/etd

Part of the United States History Commons, and the Women's Studies Commons

\section{Recommended Citation}

Coryell, Janet L., "Neither heroine nor fool : Anna Ella Carroll of Maryland" (1986). Dissertations, Theses, and Masters Projects. William \& Mary. Paper 1539623763.

https://dx.doi.org/doi:10.21220/s2-x87v-rf88

This Dissertation is brought to you for free and open access by the Theses, Dissertations, \& Master Projects at W\&M ScholarWorks. It has been accepted for inclusion in Dissertations, Theses, and Masters Projects by an authorized administrator of W\&M ScholarWorks. For more information, please contact scholarworks@wm.edu. 
Coryell, Janet L.

NEITHER HEROINE NOR FOOL: ANNA ELLA CARROLL OF MARYLAND

PH.D. 1986

\section{University}

Microfilms

International soon. Zeeb foad, Ann Artor, MI488100

Copyright 1986

by

Coryell, Janet L.

All Rights Reserved 
$\therefore$ 
Neither Heraine Nor Fool:

Anna Flla carroll of Maryland

\begin{abstract}
$a m-m-m-m-m \infty n-m$
A Dis:eretation

Presmeres to

The Faculty of the Department of History

The College of viliam and Mary in Virginia
\end{abstract}

In Paxtial FuIfimment

of the Reguirements

for the Degree or Doctor of Bhilosophy

BY

Taner I. Corgend

1986 


\section{Copyright 1986 \\ by \\ Janet L. Corye11 \\ All rights reserved}




\section{AEPROVAI SHETT}

This dissertation is submitted in partial fuleiliment of the requiremests for the degres of

Doctor of Philosophy

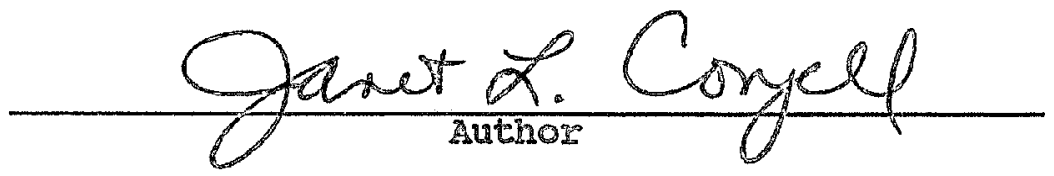

Apgroved, JuIy 1986

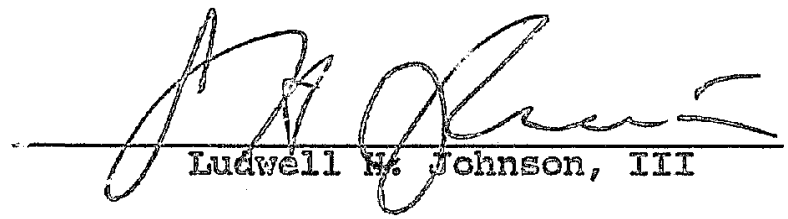

Me nanler

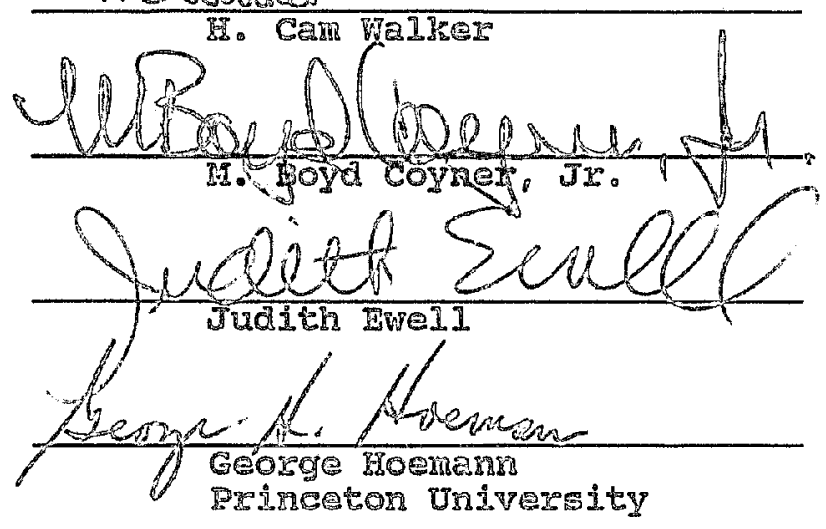


To my grandmothers

Bomie Coryel I Fateh

and

Florence Ray Lewi:

Who algo Love Education and Fistory 


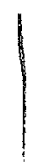

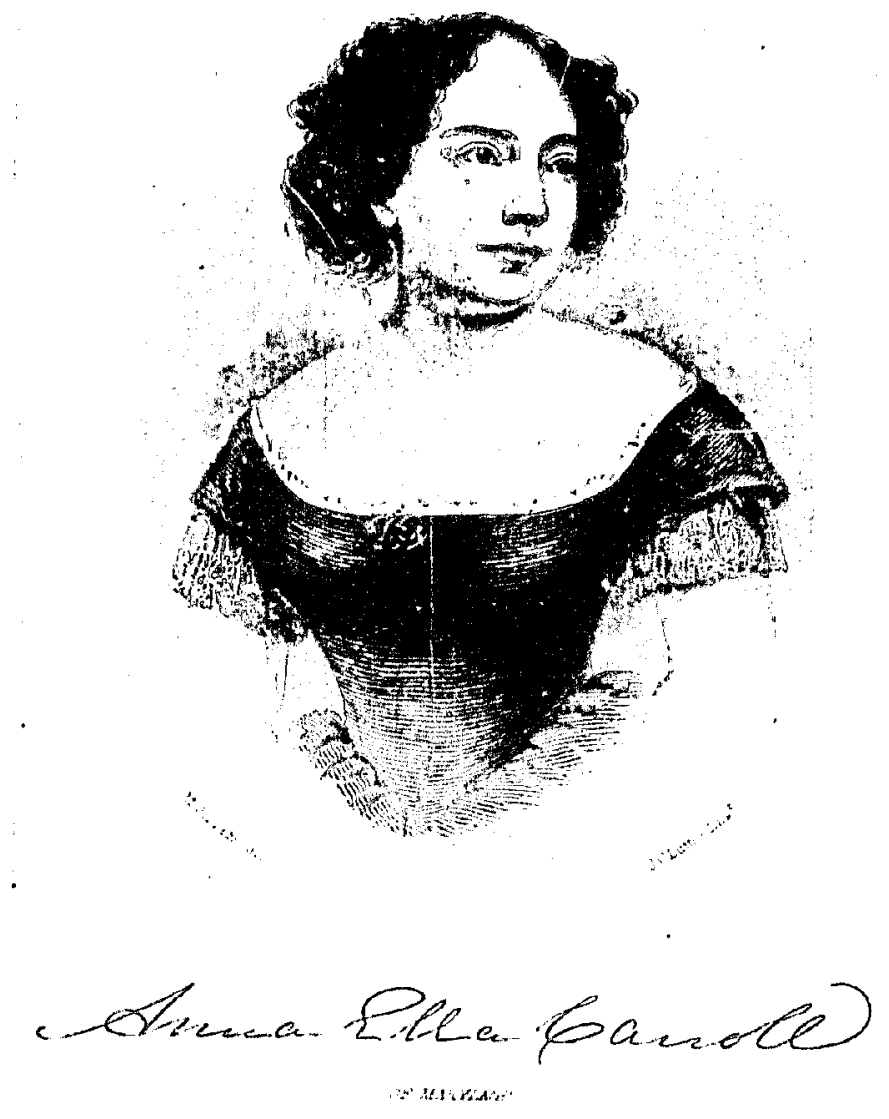




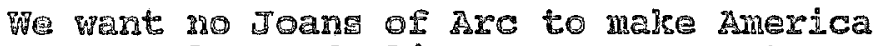
vascular and allve. . We want fajthful and true women, who neicher ghrof is nor protest, but pray; vomen who neither mount nor sink: who are neither heroines nor fools: but Americans women, who can gLand in their shoes 。. .

- anna Tla Carroll The ereat Bmerican Battle 


\section{Table of contents}

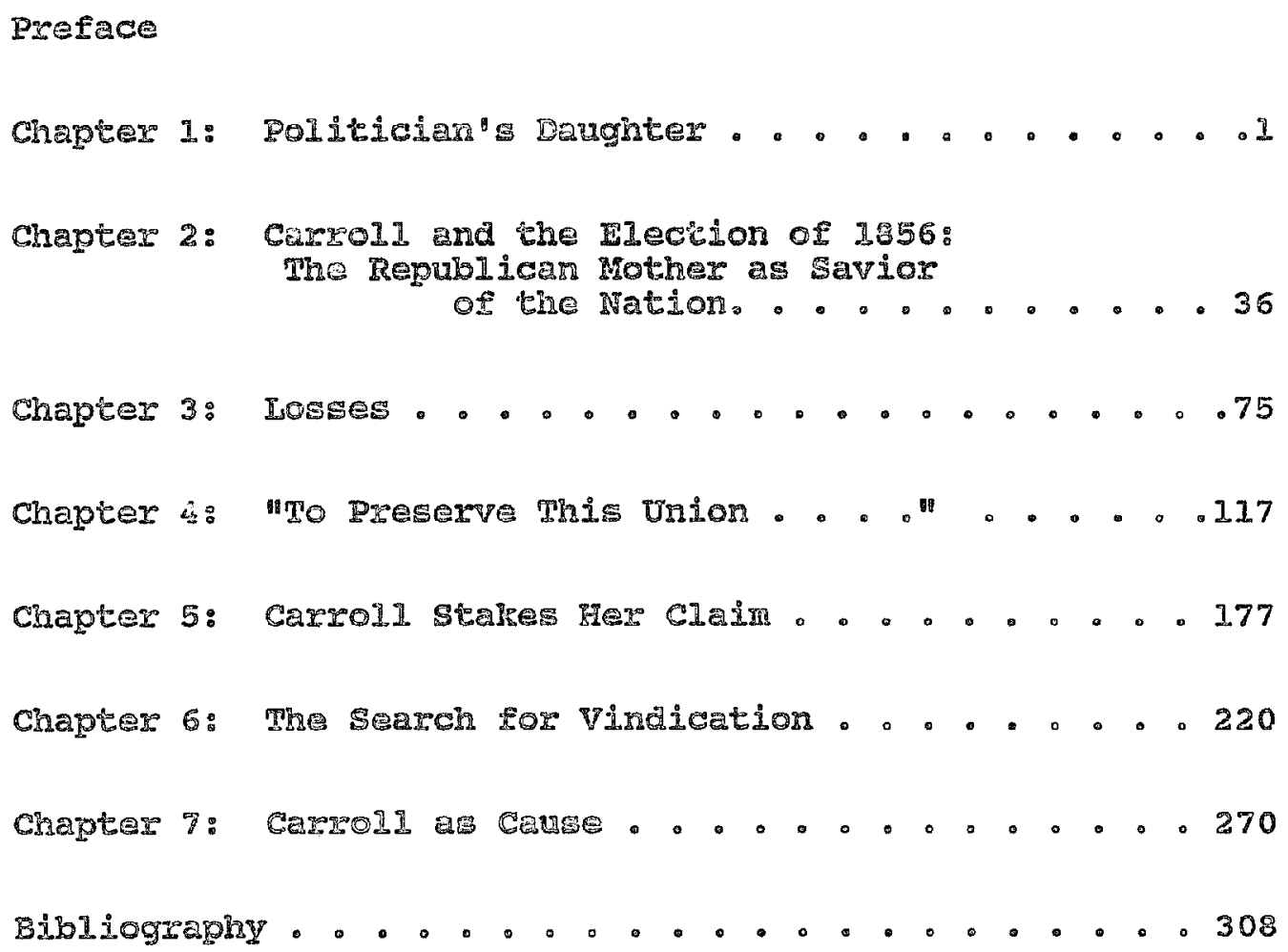




\section{Preface}

I began my research on Arna El1a carrold certain I had discovered a much-maligned, forgotten heroine of American history, mon I would redefine and properiy place in historiography. To try to find the truth about a woman surrounded by so mah legend has been an enlightening experiance. Sorting out ber story as best I could has made me aware of how comples the past is and how difficult biography as a crart is. The Iate Distinguished Teaching Profesgor Ralph Adam Brown, biographer of John Adam, Irad taught me that my sophonore year in college. He was right.

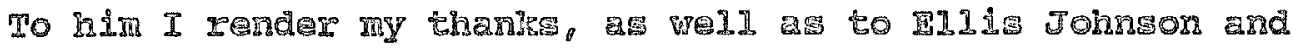
Donald sterat, mino introduced me to history and to Anna Flla Carro 11 as author of the Tennesses Campagr. Carroll was one of the zew women discussed in the Civil war course sterart and Johnson taught at cortland State. She was a legendary figure, and 1 ijse all good legends, there was at least some sanse and some truth to her

clain. Discovering the mhole story turned ont to be 
aifficult.

In part, the difficulties lay rith source materials. Some of Carro11's parers had been preserved, but many had been lost during her life. others accidentally buaned in a house fire in the 1940s. The coldection in the Maryland Historicel socidey is extensive, but consists mostly of Ietters redelved. Tracing letters witten that stiI

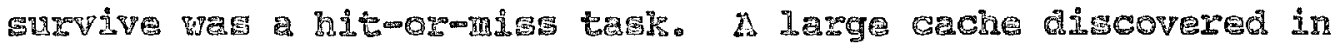

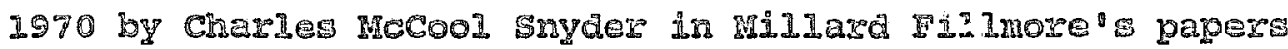
in Oswego, New Hork, helped the most to portray three-dimensional Plgure instead of a noble legend. so did letters from carroll to Wi11 iam Henry Seward and Thurlow Weed at the university of Rochester. But most ingringe: to collectons of carrol1 ${ }^{\circ}$ G correspondents resulted 2 a dimeppointing reply。

Important sigures In Carroli 19 Ife remain shadowy. Leme1 Tvans, Jonn Causin, and her Gather, Thomas In Ing

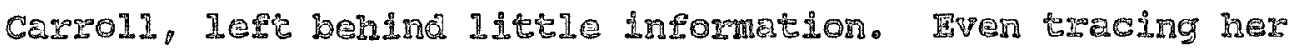

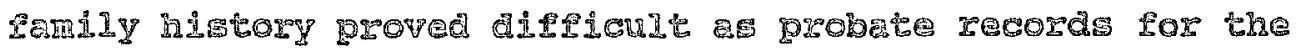
appropriate parjor hav not arrvived. mhere mere, to be sure, areidales anc boolse about Carroll's life, but virevally all were repotitions of the story of her military dain that she tried for vo long to have the morld accept ard believe.

T0 10015 beyond that story has been my tasls. I have had a Eascinating gimpse of a minetents-century anomaly: a well-educated southern woman, a Unionise who hated slavery 
but refused to support emancipation, a citizen of a state known for religious toleration, yet a virulent anti-Catholic. At the same time, I have been frustrated by research that at times raised more questions than it answered. Was she a swindler, a fraud, a cheat? Did the mIItery maldously degtroy records that would have proven she was a brilliant strategist? The answer to the first is still uncertain. The gecond I hope I have answered at last.

One of the final tesis and great pleawres in finishing work is thanking those geople who helped you. Professor Iudme1 Jomanen read my manuscript several times. Fe guestioned my generaljutions, sharpened my prose, and repositioned many of my verbs. I thang him fOr his timely

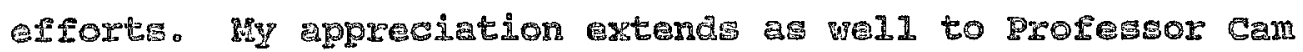
Wanger and to fditor George Foemann. They also read parts of this work and gave invaluable nelp, criticism, and suggestions. Committee members Boyd Coyner and Judy Ewel I posed occasional grestions that led me in new directions to the bangtit of the mhole. Part of this work will appear in a book on aremcan women and foreign policy edited by

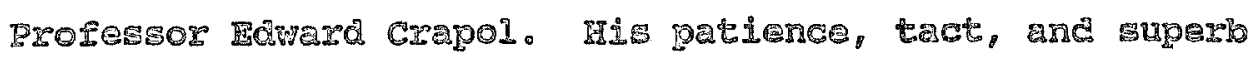
altorial Grticism are, I hope, replected to some degree in the eredre roms

Del Moora, Coordinator of Reference services, and carol tinton, Mead of Interibrary Loan at Swem Iibrary. 
were unstintingly generous with their time and labor. Carol in particular accomplished miracles ferreting out obscure source materials and convincing libraries to loan them to me for extended periods of time. Along with these two particular individuals, I must render ny appreciation to the College and the History Department. They provided two research grents, microfilming costs, computer space and time, and generally made the mechanics of my worls much easier.

Rayen Stuat of the Mayyland Histoxical Society was MeIprul from the beginning of this project, as vas Marcia

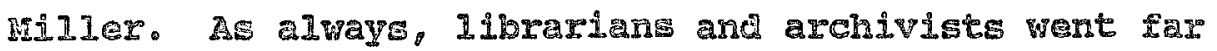
beyond the call of duty at the Iibrary of congress, the National Archives, the Hall of Records in Annapolis, the New York Public Iibrary, SUC Oswego, and the university of Rochester.

Carro11's chilahood house gti11 gtand in somarset councy. Diers and . B. Warbasse graciously invited me into their home and showed me the wooden shoe that was sald to have been woxn by a slave at $\mathrm{k}$ ingston Fall during the temure of the Carolls. They provided hospitality and interest, evan in a revisionist history of their house's most fanous occupart. My thanks to Paul Touart of the sorerset county Figtorical prust for helping me find that lovely home and its hospitible occupants.

The Iowe and support of ray family and friends during 
my work has made my life a joy. Ken and Nora Coryell provided not only sympathetic conversation but generously gave me a home away from home during research trips. They and their children supported my efforts on the East coast, as did my parents and the rest of my family in Ransas.

3y friends and colleagres became my family here in wi1liamsburg. In particular, I want to thank Folly Mayer, Geil Terry, and Camile Wells, who asted me questions designed to focus my work nore clearly: the w1IIIamsburg Prewbyter.an Chureh Choir, especialyy Jeanne Rent and Tom marshall, who gave me escape and austenance through music For four year: and Ben Rel 1 am, who drew rnaps served as a valuable resource to explain the wastern shore to me, and helped me lools at my work with an English major's eye. Most particulagy. I want to thans John and Ruth Am Coski, and Mary anol James Perry. They not only IIstena, but provided caring support far beyond any call of triendship for myself and for IVan.

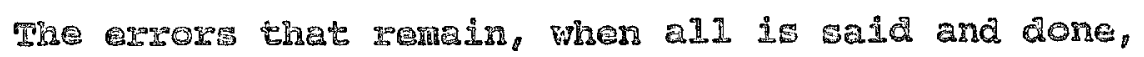
are mine. 


\section{ABSTRACT}

Born on the Eastern Shore of Maryland in 1815, Anna I113 Carrol1 was the eldest daughter of Maryland Governor Thonar IRing Carrol1. By the early 1850s, she had become a political parphIeteer for the merican, or Inow-Nothing. party, a nativist and ant-catholic organization. She wrote a number of books anc elestjon pamphlets suppogting the presidential candidacy of Hillard Fillmore in 1856. In the election of 1860 , she promoted the candidacy of John lninor Botts 0 V Vigginda, e strong Unionist.

once the Civil Waz began, Carrol1 worled to support Iincoln ${ }^{\circ}$ action, often criticized as exta-legal, and wrote several pamphlatis on his behad. She argued, as did Lincoln and his other supporters, thet the Bresident could wield war-malning powers to preserve the Union, even if wielaing those powers infringed on certain legal righte. 2 number of pol1tician achonledged the value of her argurents suporting the President position, and one panphlet mas printed by the administration and lasa on overy desh in congress.

Carrol1" nost Pamous worls ceme during the tall and "rinter of 286, when she visited the werters pheatre of the war and devised a plan to invade the confederacy by going up

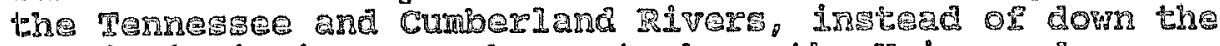

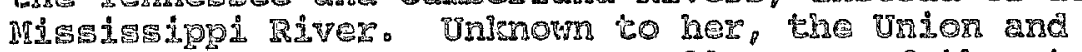
Confederate forese both were well aware of the stratogic value of the ripers, ard already had plans to proceed in the manner sue wuggested to the pro Depertinent. convinced ahe sad presented a plan thet sed saved the onion by providing a

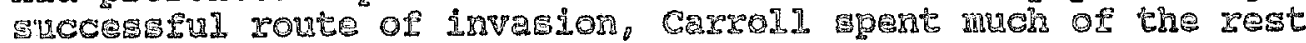

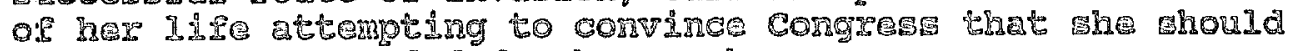
be generous?y artared for her worls.

carsol I' 1980. Until the turn or the century suffragists organizations and periodicals supported Cargoll and her

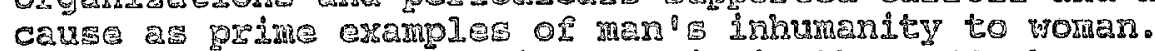

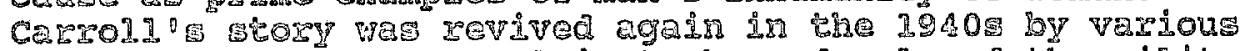
writherg. Although ber claim to have developed the military stretegy used by the undon army in Temnessee had been disprover, 1 t more substantial.

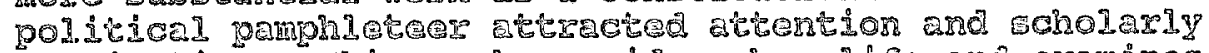

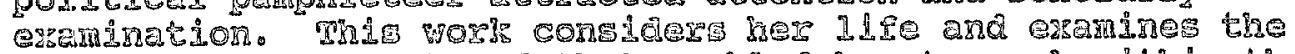
methodology she mimloyed that enabled hes to work whthin the polithea wohere while retajning her comecthos to the "remale gphere." 


\section{chaoter 1}

\section{Politician ${ }^{\circ}$ B Daughter}

The weather is hot on the Eastern shore of Maryland in August. Eumidity can lie like a blanket across the flat farms and small villages. Iate afternoon thunderstorms do not relieve the heat but make it closer, till moving itself becones an effort. A breeze from Tangiex sound or off the Big Annemesser River might breals the heat in Somerset county for a little while, but woon that breere would die and the oppressive air would return, along with the hordes of mosquitos and the minirring of cicadas.

Anna Flla carroll. was born August 29, 1815, in Somerget County, Maryland, the eldest child of Thomas King CarroIl and JuIianma stevenson Carroli. WeIl meducated, independent and articulate, carroll became a political rratey and lobbyist in the mid-ninetenth century. Actively involved in politicg throughout her life, she achieved notoriety when whe claimed to have developed military 
strategy that led to Union victories during the Civil war. Carroll used her intellectual gifts and her ability to manipulate politicians and the press to developed a methodology that enabled her to pursue a lifelong interest in politias within the cultural strictures of the "woman's spliere."

The carrolls of somerset county claimed a common ancestry with two of the most distinguished families of Maryland, the catholic carrolis and the Protestant Rings. The Carrolls came to America in 1689. Char'es Carroli, patriarch of the Iine, had been appointed recejver of tord Batimore's rents from the Maryland colonists by 1691 . one of his grandsons was charles carrol, "The signer" of the Declaration of Independence. Mnother was the Most Reverend Jonn Carroll, the first catholic archbishop in the United Stgits 1

Kingmer to Charles and John was colonel Henry James Carro11.2 II 1792, colonel carroll had married glizabeth

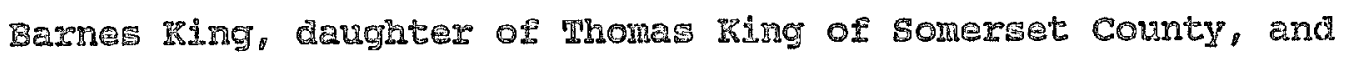
a descendan of Sir Robert IRing, a Presbyterian aissenter whose faming ha left Izeland for Maryland in $1682 .{ }^{3}$ one of the ridner wlanters on the Eastern Shore of Maryland, Fing was less ther pleased et his only chid's choice of husband, but he :ettied the yourg conple on an adjoining

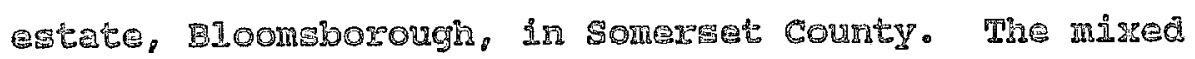
marrlage of cathollc and protestent produced three sons. In 
1798, at age five, the eldest boy, Thomas King carroll, went to live with his grandfather king on the family estate of Kingston Hal1, where he became "the object of sir Thomas Iing's devoted affection and brightest hopes. ${ }^{44}$ Thomas IRIng Carrol 1 was brought up in the best English gentry tradition, whth coaches driven by glaves in Iivery and all the accoutrements of an English country 1 ife transplanted to Maryland. Bbow 1802, Thomas $\mathrm{King}$ died, and

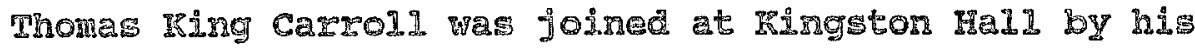

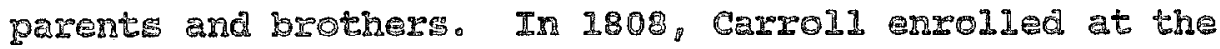
University or FempyIvania where he canned a bachelor's

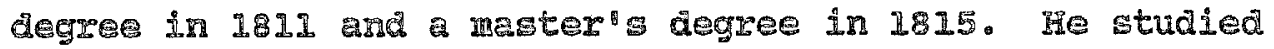
Ian and becane partner to Robert Goodloe Harper, the son-13-1aw of Chardes Carrold of Cerrollton. on June 23 , 1214, he margied Julanna stevenson of Baltimore, the deughter af a prominent physician, Dro Henry stevenson. Dr. Stevengon had converted his home in Baltimore, Paxnassus Fi11. into a charity smallpos hospital for the clty in 1754 in an efrort to promote mallpor imoculation. Another relative, Dr. John Stevenson, Mas sald to have laid out the plan for the city of Baztimore. 5

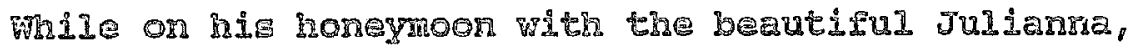

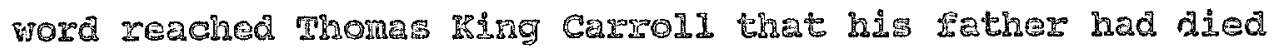

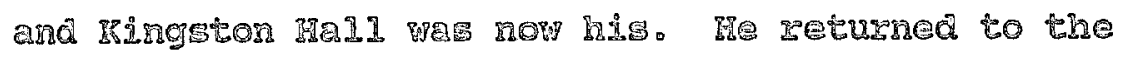

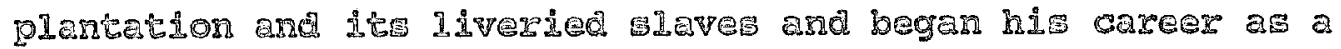
planter. But farming did not partioularly interest him, and 
politics did. After his return to Kingston Hall, and before his daughter Anna was born, Carroll stood for election and won a seat In the Maryland legislature, the youngest member ever elected. His twenty-first birthday came the day before he took his seat. EII political activities would eventually lead him to the governorship of Haryland. The state wich carroll served as legislator and governor has been called by one historian "an Mmerican microcosm." It: border position straddied the agricultural economy of the south and the growing Indugtzilaligation of the North. Maryland was never adeguately or comfortably defined as a "morthern" or "southers" state in mational matters. By the time of the American Revolution, grain had replaced tobacco as the primary staple Grop and Battinore vith Its active harbor wa the fastesengrowing aity In the new nation, but blak Blavery and the plartation system of agriculture still fouriahed in the state. In 1663 , wome thitry yaus aftex the colong hed been founded, there had been enongh slaves in Maryland to elicit statutory recognition of their extstence and legal status. Mide in 1783 Marylard had banned the slave trade, ard in 1794 had gtrengthened lavs against importation, the large plantations in southern Maryland and on the rastern shore needed Have Iabor so survive. Its abolition was unimely, givan the political power or those azeas. 8 


\section{Even through the fixst part of the nineteenth} century, as the Maryland economy divcrsifled and the cities began to grow state politics remained the province of the SLave-owing landed gentry. Two thirds of the Lawmakers from 1789 to 1330 were from the plantations of the Eastern Shore and southern saryland. In this groun were wen such as Bobert Good Ioe Harper, who re-organdad the Maryland

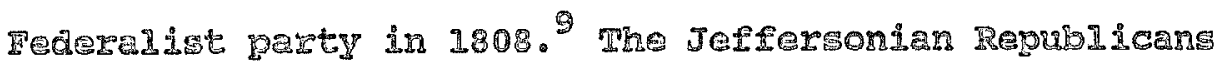
mere the ascendant party in tre state miti 1812. but the Federaligte predominated through most of the war of 1812 . A

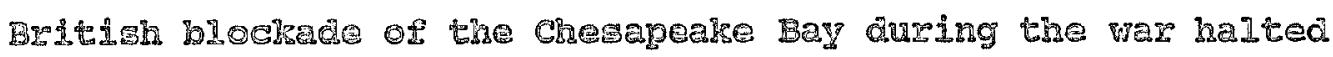

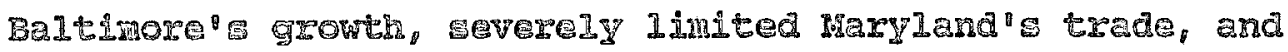

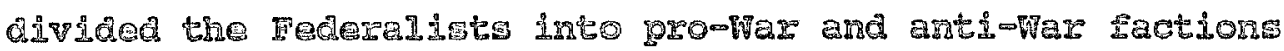

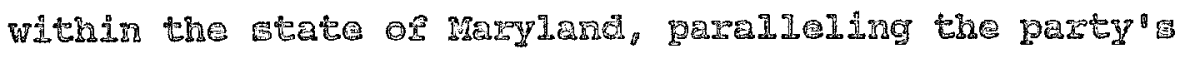
national split. ${ }^{10}$ In spite of the Federalists natonal decline arter the was. however, the party retained

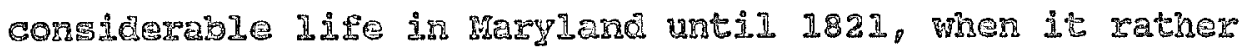
mudenh dy

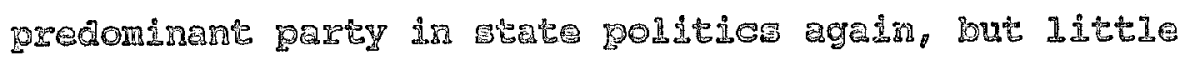

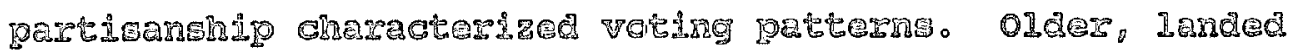

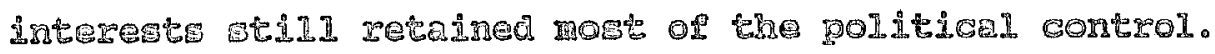

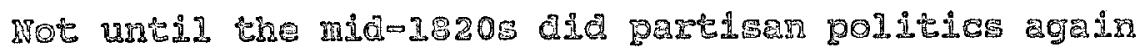

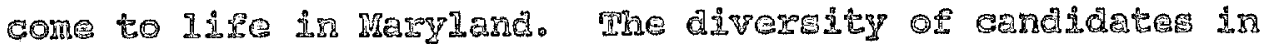
the 1824 presidented rese zearagrened polithad interest throughout the state. an official Republicar caucus, a metrod thet had been 
falling into disrepute, and failed to gain much support in the state. Candidate John $c$. Calhoun, on the other hand, enjoyed considerable notice from former Federalists such as Robert Goodioe Harper and former state senator Virgil Maxey. ${ }^{11}$ But it was Andrew Jackson who attracted a more mubstantial portion of former Federalists than did the other candidates. Popular support for Jackson was strong in Baltimore. Celhour supporter: including former party

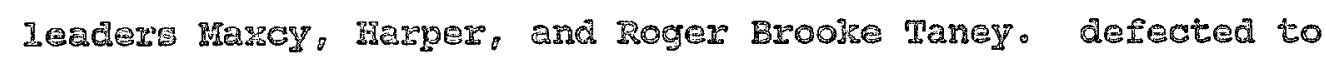

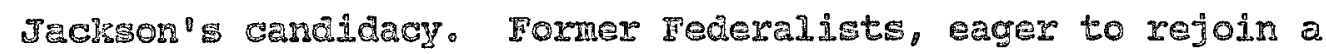
party with pover, perceived Jackson as the only candidate 日ndependent of party intrigue and contral." He was a man

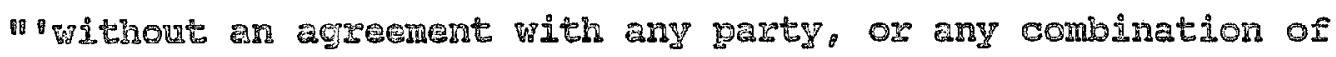

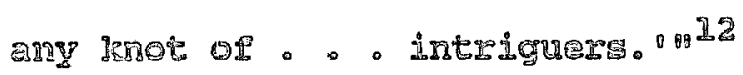

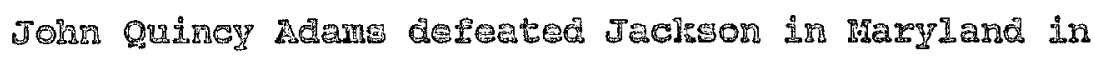
the 1824 election, and won the national ellecton, which was

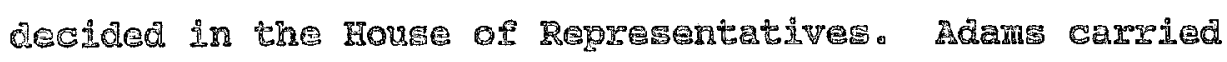
southern maryland and the Eastern sinore, but Jackson mon ฐtzongly in Baltimore and the wetw. By 1827, preparing for the nest election, parties had coalesced more firmly. The majority of the Federalistr went with Adams men: the old

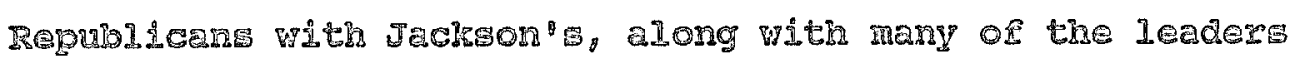
of the old

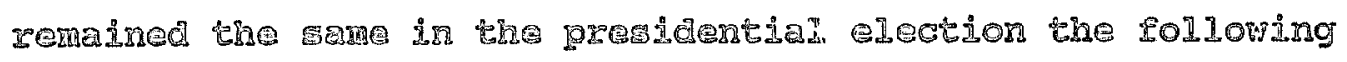

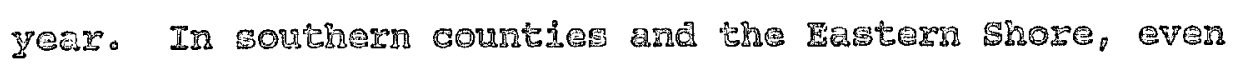

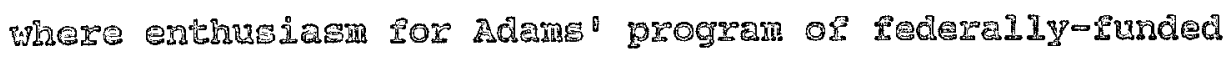


internal improvements was slight, Marylanders preferred Adams over the more "imprudent" and hot-headed Jackson. 14 But Baltimore and the western counties maintained their support for Jackson and his notto: "Jackson and Reform. ${ }^{15}$ so did at Ieast one Eastern shore politician: Thomas Iring Carroll.

Carrold had been a member of the state Fouss of Delegates in 1816 and 1817 and had worled as a judge in the Levy Court of Somerset county before being appointed Judge of the orphans court in February 1826. In December 1829, after considerable fighting between former rederalists and former Republicans, the Jachsonians elected former Federalist Carroll as governor of the state. 16 Fis term as governor lasted a little over one year, however, as the Jacksonians lost porer. The political sallout from Jackson ${ }^{\circ}$ Fetoes of internel Inprovements and, importanty. over his distribution of executive patronage, gave carroll only twelve montis in office. He conda accomplish Iittle. IJE dir mange to promote edrcation.

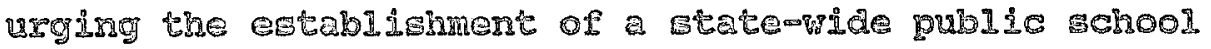

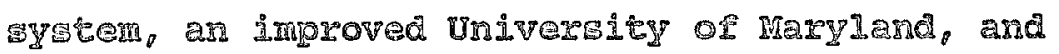
congressiona approprdations ror copying BrItish-omed Rovolutionary war records. 17

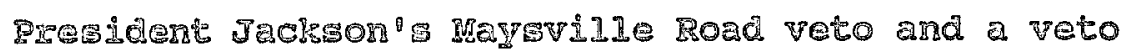
Oy a grogsed

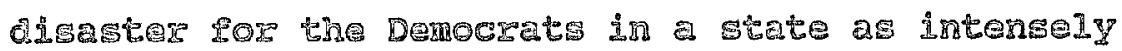


interested in internal improvements as was Maryland. ${ }^{18}$ The Jacksonians quickly lost control of the state legislature, and in November 1830, Carroll lost the gubernatorial election to the anti-Jaclssonian Daniel Martin. ${ }^{19}$ Upon Carrol's retirement frow the governorship in January of 1831, he was elected to the atate senate but refused that position, as well as the suggestion he run for united States" senator. He retumed to the pressing business of trying to mare a success of his plancacion ln Somerset county. 20

Carrol1 had his wort: cut out col him as he returned home to Kingston Hal1. The 1819-22 recession had badly dameged the econony of Baltimore and Naryland, ard the state was only just beginning to recover by the eaxy 1830s.21 The state's heavy and finmeialy imprudent irvestrents in

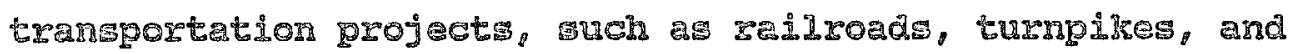
canals, led to subtantias and unpopular tax ircreases to pay off the remutant deficit. 22 The farming sector of the economy ma sufferea even more as those taxes strained a collapsing agricultural base. The tobacco crop had given may to wheat by 1815, but that crop was decimated by ar infestation of the EEssian fly. Inand use reverted to tobac6, whida exhausted the soli, or to scrub pins, whin

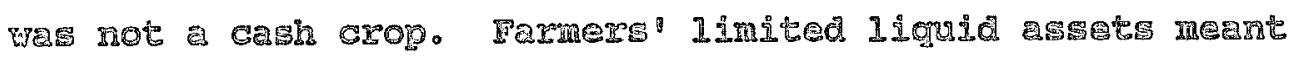
agricultural esperimentation to increase production was

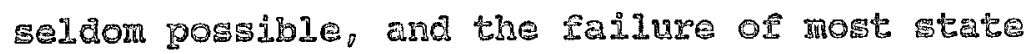


transportation projects to extend to more ruxal areas further reduced the vitality of the agricultural sector, particularly in the older and more renote counties along the Fastern Shore.23

Added to carroll 's problems of recession, high tases, soil exhauston, trangportation difficulties, and the alway Gyclical and variable nature of farming was the groming problem of slavery. In splte of marland

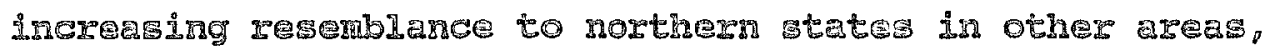
2ts hold to thls tie with the south contributed to its tendency tonara occasional pro-southern sectonglism and pro-slaverg political positions. That attitude was most prevalent on the Eastern whore and in southern Haryland. where mosc sIareholders resided.

Carrol1 felt difrexenty than meny of his nejghbors. Although conditions for sleves In razland rere relatively mider chan sor bondsmers further ronth, the institution did

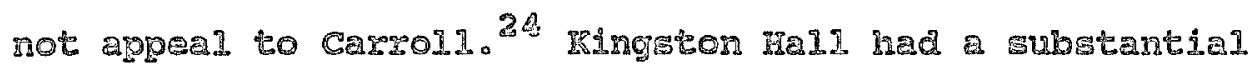

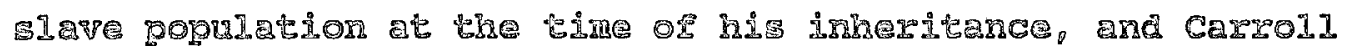

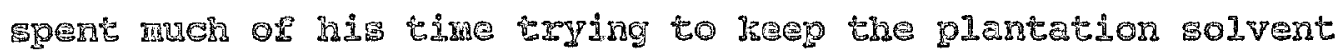
anough to prevent theire sele.25 He did not wree theno apparenty feeling, as d이 many maryland slaveowners, that rreed 5laves nad no proper or sare place in a slave-oming society, bur he was ar advocate of the Arrican colonizetion

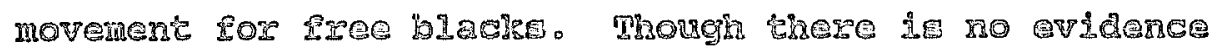
Carroll 


\section{Society, as were other leading Marylanders of his} accrsaintance such as Harper and Charles Carroll, undoubtedly he supported its efforts to remove freedmen and women from their unpopular position in the state to the fraryland colony in İberid. 36

In

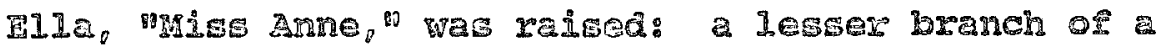

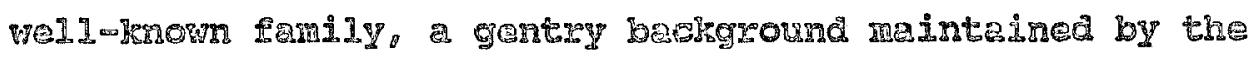
most precarious of finances, a border state that vacillated botween sectionalism and nationelism in its society.

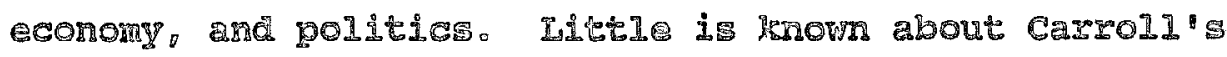
childrood. She had five younger sisters: Salije, Mda, and

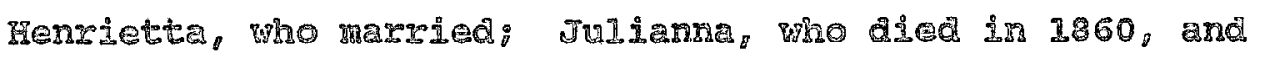
Mary, who semained single. She had two younger brothers:

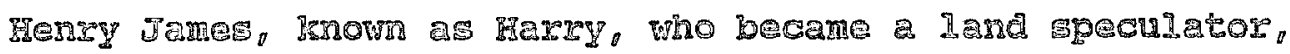
and momas ring, who became a poor couniry doctor. Anothar Younger brother dLed L insency. 27

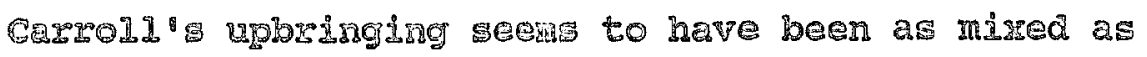
the rorlo is which ghe Iived. ser sether treated her education a: he would a mon ${ }^{\circ}$. She read colke and BIacrstone on 1อ , Shalsespearean drema, and gantian philosophy in her Eather"s library, as he had done in nis grandfather" ${ }^{\circ}$. Ber domestic education was aprarenty not seglected, but her Inceneste and enjoyment lay with bools wethex than with the accepted and comon accomolimments of not upter-cless

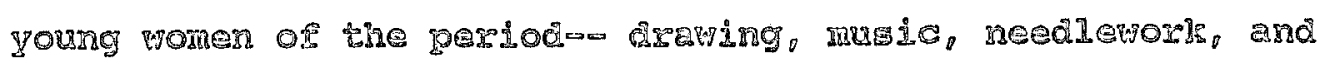


household tasks. 28 politios fascinated her. By 1830, when ger father took office in Annapolis, Carroll's political education was such that letters to her "wisest and dearest of tathers" were soringled with precocious political coments anongst the news of home. "It is my principle, as weII as thate of Iycurgus," she wrote age 14, "to avoid

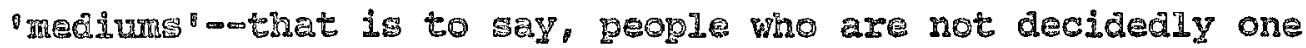
thing or the other. In poldtics they are the inveterate encmies or the state. 29

At fifteen. during her father's brief temure as governor, Carroll mas sent to miss rargaret Mercer's boarding school in Hest IRvor, Haryland, to finiwh her educetion. 30 Athough she seems to have spent less than a gear under Mercer's tutelage, her teacher ${ }^{\prime} \mathrm{v}$ views on education and glavery mate have nerved to reinforce her father ${ }^{\circ}$ opinions. Mercer too was the daughter of a governor of Iraryland and had been taught by her father. She preierrea the concrete to the metaphysal in ine teachings in wcience, phlosophy, ebnjos, and religion. Beyond ectucating ner iemale students for their

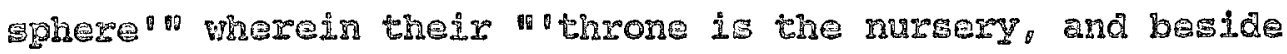
the cradle, mercer beljeved her girls neded an education "1 Fỉำ and the virise which are regrisite to the sarety and prosperity of the south 31 But mercer manimained, as Garroll wornd in lacer years, that edreated woner rust not 
despise "the refinements and delicacy which communicate an appropriate and attractive grace to the female character. These can never be laid aside, no matter how great the positive acquirements without a violation of the laws of nature. ${ }^{32}$

IdHe many women in the 1820 s and 1830 , Mercer wes interested in the abolition of slavery. Her position foreshadowed the one that Carroll would take twenty years 1ater. Bware of the economic and wocial upheaval for both master and slave tinat accompanied amancipation, Hercer preferred graqual mansipaton with compensation for omners and voluntary colonimation of Ereed slaves. She bought glaves herself and freed them, hiring some to work on her estate, and proviaing pasage to Iiberia for those who whised to go. She asked her students to contribute to the cause and corresponded with northm abolitionist leaders such as Gerrit Smith in search of support for her programs.

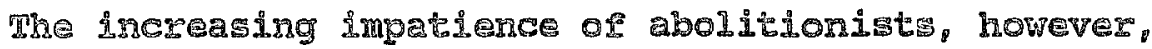
eventualy promgted breal with them. Mercer wanted abolition, but, she wrote, 4 I will temper my geal with as much discretion as ny nature possesses. m $^{33}$ While Mercer"s position on educacion and slavery no doubt met with Thomas Cerpol': approval, his finances apparenty and not allow Arme to continue her eôcation. Egr-Governor carroll returned to RInoten Ha1 His wife JuIiane was i11 and his plantetion approaching 


\section{financial ruin.}

As difficult as farming was, by all accounts Carroll was a poor manager of finances as well. His refusal to sell unneeded slaves, while no doubt viewed as a humanitarian gesture on his part, aid not prevent him from using those same isves as collateral fow mortgages reguired to pay off loans he pad co-signed for improvident friends. ${ }^{34}$ The Chancery court records of somerset county contain severaI lawsuits in wich carroll was reguired to pay off nortgages for others. carroll had a particularly difficult time in 1835 and 1836 , as he sold two slaves, a parr of horses and a carrlage, and "one black horse and one sorrell [sic] horse" to satisfy judgments against him. 35

By the mid-1830s, Mnse Carroli took the rirst steps of mhat would become her Iifelong task of trylng to help her fami1 ana particularly her father, steay arloat financially as she opened boarding ghool on the plaxtation. Hers attempt to postpone the inevitabie did not succeed. The school c10sed, and In 2837 , as a inarcial panic swept the country, Thomes Ring Carroli 105t Fingstor HaII. It ras sold by the sharifi, and the famiy moved to Catse Haven, a smaller estate 3 churech creer, Dorchester county. 36

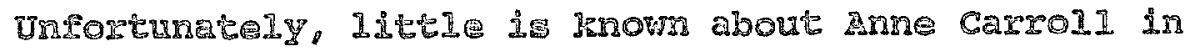

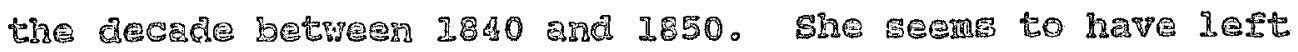

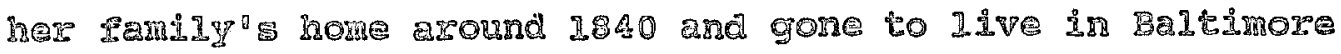

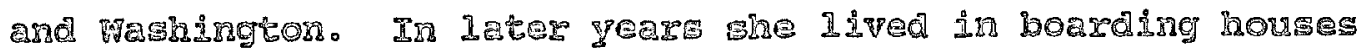


with servant or two; more than likely she established that pattern in this decade, since no evidence suggests that she established a separate household. ${ }^{37}$ she apparently worked as a pronotional writer for railroad lobbyists, and contributed letters and short articles on political ratters to local newpepers. ${ }^{38}$ shes the vast majority of her work was pennac anonymously or under a psendonym, axamples of her witing are alficinte to find and to socument. 39 she crmmted ofter between Baltimore and Wasington, elway searchting for way to make morey 20 werselt and her fanly. In one letter, written in Hovember 1848 from Washington, she complained that hez latest financial plans had salien through an that arranging a martgage on some Maryland real sstate world have to suffice to raise funds so whe could return to Maryand to cere for her alding parents. Ier Lather recovered: her motrer did not and died on JuIy 31. 28490

Carro:d's agarture from the capital city had loen ondy temporary. By fiprid 1849, she bad returned and petithoned che new Why Secretary of State, John M. Clayton,

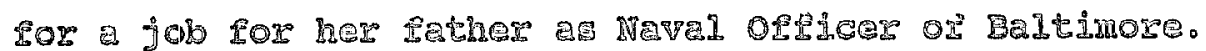
Fromas Carroli had hocowe a whig by the $1840 \mathrm{~s}$ and had saryed

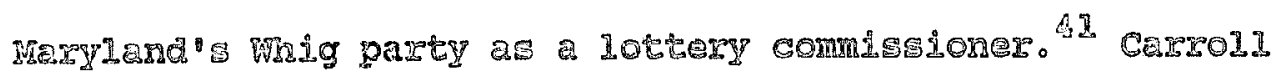

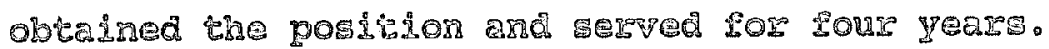




\begin{abstract}
With her father's immediate financial future more secure, Anne carroll began to involve herself and her pen more deeply in national politics. At the age of 35 , unencumbered by husband or child, whe took full advantage of her intelligence, her education, and her family connections to partioipate in the political Iife of the nation"s aepitละ
\end{abstract}

Because she was a wornan, Carro11': participation was necesgagily Iimited. She Aid not choose the paths of woman's rights, abolition, ox reform, as did many political women of the mid-nineteenth century. But she was determined to exercise influence over loading politicjans. Through her Ietters and metings, she hoped to have an eftect on political appodntments. She would suggest her father as a cardidate for office regulary. after his tenure as havaI Officer had nded: Ghe would also suggest and eventually demand, appointments for many of her friends and for gersons Ihe thought would serve the goverment well. Carrol.': unusual education and natural inclination toward politics had served to train her nind. By 1850, slse had honed her

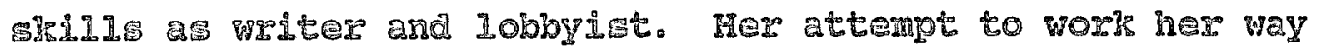
lnto the circles of national power could now begin.

From is fer letters of carroll's that murvive from

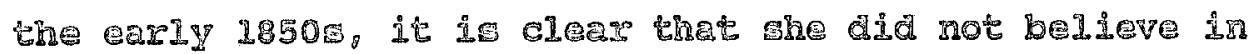
wagting thme or anergy commsicating with the lower cohelons of bureaveray. For her Lather" appoirtment as Napal 
Officer of Baltimore she had written directly to the secretary of state, even though his appointment was from the Department of the Treasury. But, she wrote the secretary, "go high is my appreciation of yourself, so perfect is my conflaence in the efficiendy of your power to serve me, that I must trust to your ow Inaking the effort to IInd a "loved Fathez" a job. Campol' 3 flowery phrases were typical of nineteentid century writing and served well as part and parcel of her method to attract the attention of political Ieaders as she serrched for patronage positions. She apoealea fint to the Irteligenge and aiscerment of those to whom she wrote, then to their sentimental side. Near the

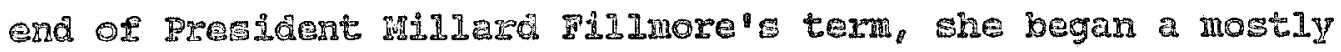

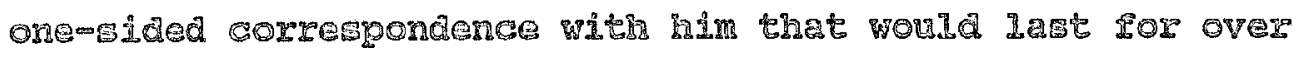
trenty years. She sert him a manuscipt to read, which he retumed "with thands for the prvilege of perusing it." Disproportonately encouraged by his polite reply " she mrote

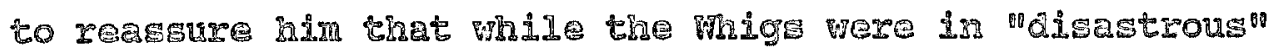

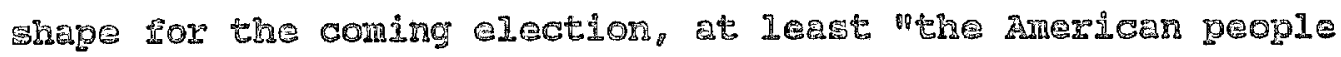

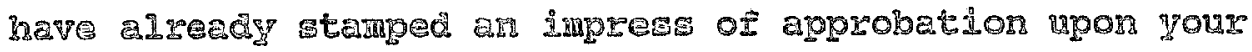
administrat come."13 By May 1952, Carro11, who had been only

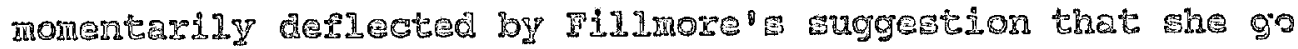

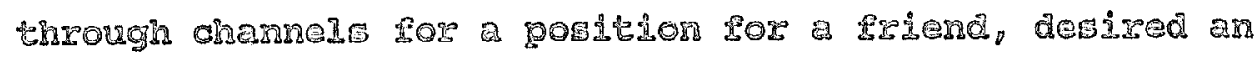

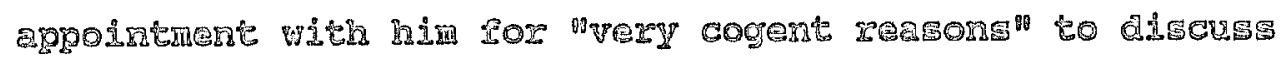


the job. She reassured Fillmore that it would be "the only case with which I shall ever presume to invite especial Interposition." signing her letter, "your little friend, A. E. Carroll," Garroll played upon Filimore's vanity and her ow supposed frail femininity to convince Filimore to do a favor for her. After all, she wote, "no selfish aspiration, no sordid isterest, 20 political distinction has actuated me." It wes just the good of the country and their Eriendship at stake.

I Iew ays later carroll wrote Fillmore again, this tine to pass on good news she had heard regarding his renomination prospects, but warning him that "traitors within your own camp" were eroding his support. Within this letter, Garoli made clear her awareness of the limitations plach upon her by her sex, as well ar preatengh her ratzonate Ror exceeding those Iimits by lobioyng for positions and discussing politics.

Fonored sis, it may look unique for as "Mnerican lady" to be 50 hearting mbarged is the interest of the politsical condition of the country. but I am sure it wil be consdered a pardonable offence, when I tell you thet by blood and name and spirt: I am identified with those who largely contributed to achieve and perpetuate our free institutions. and that by education and social position I have been ever led to an intelligent apprenension of the structure and อmtire orgendation of our political system-And a conseguert aporeciation of the wisdon and virtue of those, who have signally apheld then-o

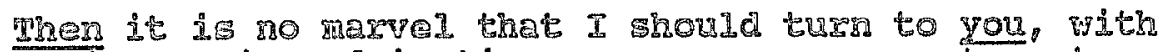
an increasing admigeion 。. . ygur very truest and

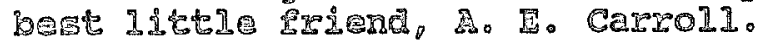


Carroll attended the Whig national convention in Baltimore in June 1852. She was crushed by Fillmore's defeat, telling him when she discovered "that the friends of Mr. Webster would never come over to you and that hope had fled. I almost sunk under it in the galdery." 46 sorrow over Filmore aefeat did not blind her to the need for apeed for obtaining any political largesse, however. Carrol1 myote five days later renewing pressure on IPIImore to appoint a friend of hexs to a position and to do It for her and for the sake of their friendship: "I do entreat you by all that is true by ali that is fajtheul. by all that wi11 contribute to my happiness . . " Sine woula see him that evening and no donnt expected the good word them. 4 When "unfrimely arrea" later told her no appointment would be made, she refused to believe Fillmore would betray her thus, and made the rather peculiar reguest that he mafe the appointment anyway, just "to show that the wisdom of a certain person is not altogether impregnable.

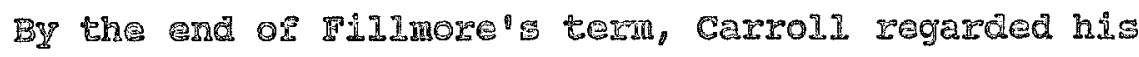
failure to meet her cienands as a personal affront. "If the President had ary disporition to professes " she mrote to Treanury secretary momas corrin, whom Carroll had apparenty mom dor mome time, she was

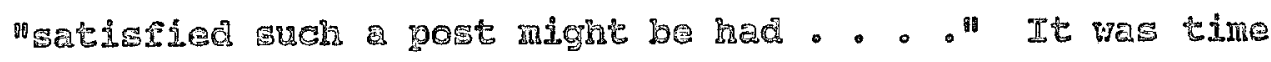
for cormin to are on her request instead, in the mpief 
period" of official power he had left at his disposal. Once again, Carroll emphasized her friendship with the official as the justification for fulfilling her request. "I know you will not forget your most faithful, your most devoted and eternal fxiend. 49 Friendship was a recurring theme in

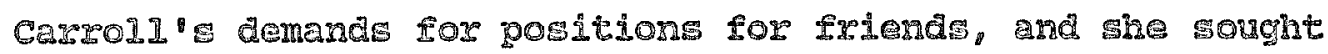
to maintain contact with political Leaders even after they Ieft office, in case their political power did not wane. Ever after FIImore and cormir were out of office and could do no more sor her, she conthued to wrlte to then as if to reasmuse herself both of their continued frienchip and the legitimacy of her continued derands for jobs. "I could not

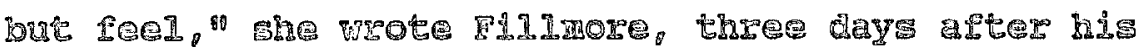

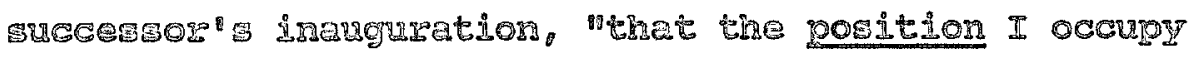

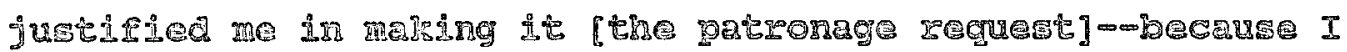

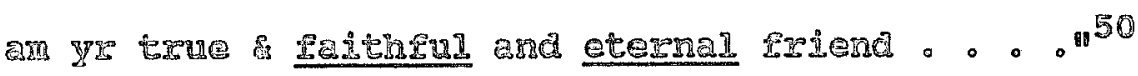

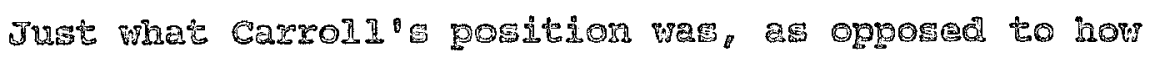

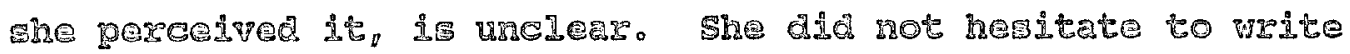
to :

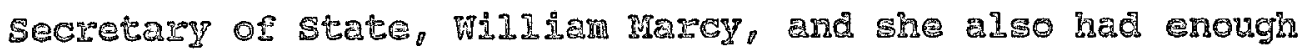

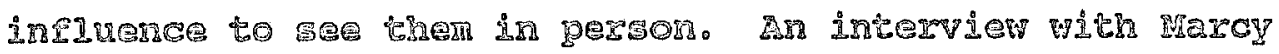
had or

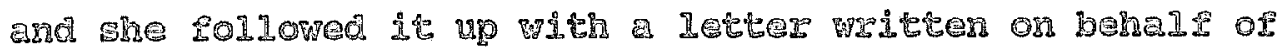

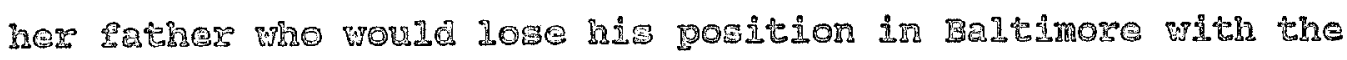

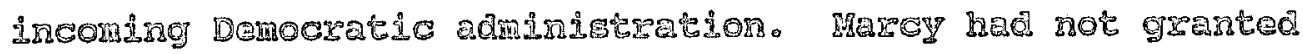
ner reguest to save har Eather"s jolo. "as a Parent, as a 
gentleman, I appeal to you," she pleaded, "to sustain the efforts of a daughter, on behalf of a pure and exemplary Father." 51 Regardless of the degree of access carroll may have had, either due to her family's name, her sex, or her womanly charms, she did not possess enough influence to obtain what she recreated. Rer father mas removed from office, and many of the requewt; she made on behalf of Qbhers for position were denied.

Carroll's politisal training served to Ireep hex argre of and gegpongive to the shifting sande of politics. At the same time she mote to the departing gillnore and Corwin with protestations of faithfuness, she began

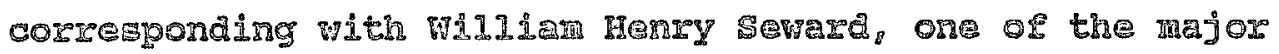
powers in the Whig party, and leader of the anti-Finmore Eaction in New York. She prajsed Mis political acumen and hi: 20 le in the nominetion of minfield scott for the

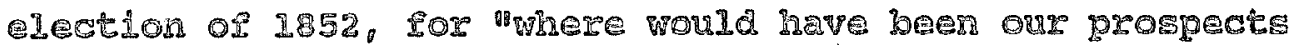
ror 3uccesg rith any other name than

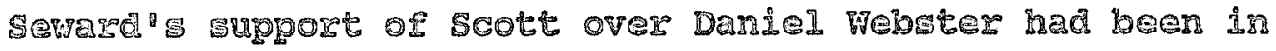

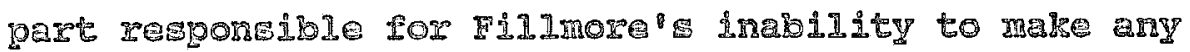
political deal thet night result in nis renomination, but no metter. Carrol1 was a podjtidLan and a pagmatist. Arter comenting mpon the "inoecility" of the Southern whigs who

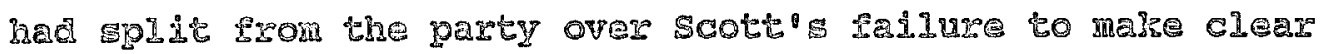

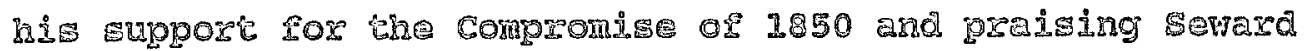

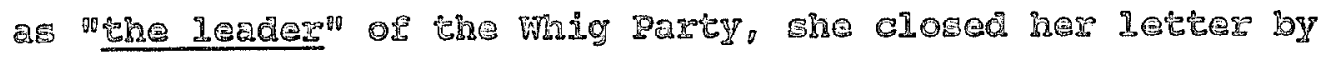


requesting seward to send his opinion of the party's chances in New York to her at the Whig Committee Rooms in washington. 52

As she had done when corresponding with Fillmore, Carrol was careful to express her awareness of the 1imitations placed upon her by her sem as she rrote. "I am a lady, but by blood \& name and splrit identified, with those, who contributed greatiy to stablinh and perpetuat. Ou Iree ingtitution." Carall was very conscious of the sisgramity of har procijvity toward politics, but she told Sฌwar, "loy educetion \& assoctation my interest is nore than

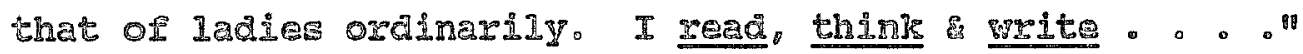
She continued to flatter serard abilities prior to the election and continned to agologige ror her temerity. excussing it as coming

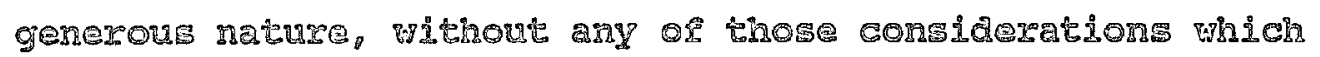
Ehe meze politician would cautiousiy inguire into.

In mpite of those reasmurances, and in spite of the Whig Hoss i̊ Hovenber 1852 , Carrol remeined convinced of Sewardis i̊mportance in the party and was determined to continue contact. As she censed writzing to the loser Fillmore prscept for notes of condolence mpor the deaths of his whe and deughter), 5A she began to pressure Sarazd to

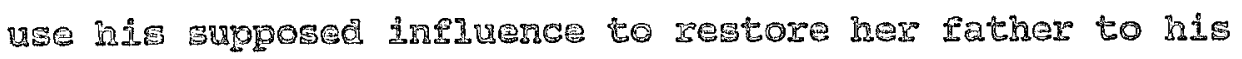

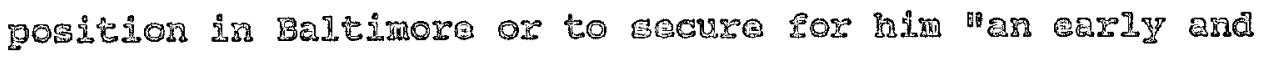
Iucretre gost." 
a daughter for a dear and honored Parent," she wrote, "especially when that effort is impelled by sacred and imperious considerations, which may involve life itself." ${ }^{55}$ once again, carroll combined the presumed political sagacity of the apointment with an emotional appeal that placed her Iobbying fox a political position withis the prowince of the "romanly sphere."

Carroll's attempt to save her father's position or get nim a new one failed. The resulthy scramble to jeep

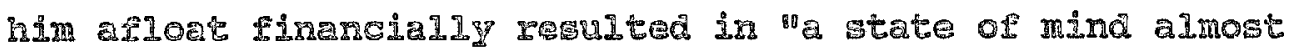
partaking of dementation," under the intuence ol which she addressed a long letter to sevard that prosented a detailad portrait of the degres to which her father"s inancial inaptinde affected Cersal1.56

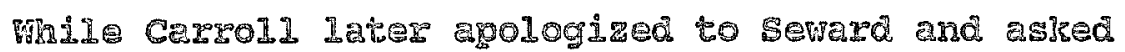
him to forget he had ever received it, her letter was remarkably frank in its obiction of carrol's concers and the sacrifices reguired by Father - . In Preaing himself, from an entanglement, brought about by the roble generosity of his heart, which grompted hin Lor others, to sacrifice his om."

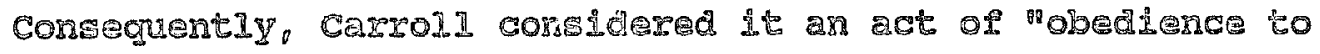

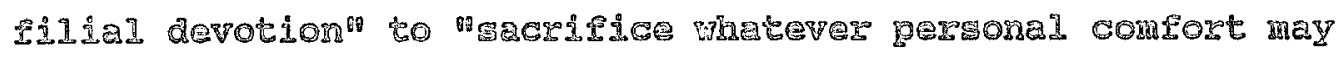

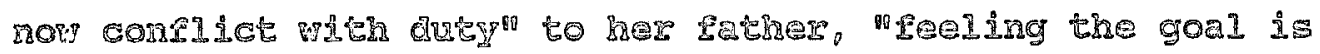

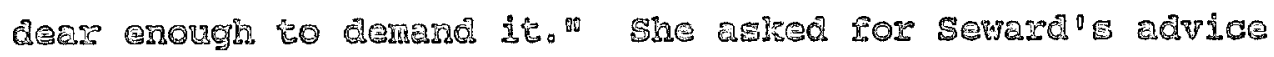

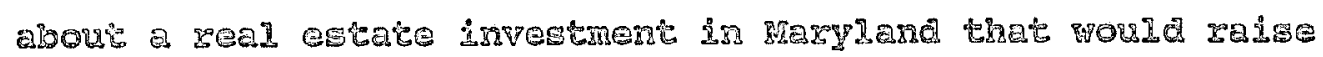


money for her father's benefit. By this time, Carroll was well aware of the necessity of protecting her father from his own "generosity." The purchase price and mortgage would be In her name. She could then maintain control of the farm, "engage mysele in whatever sphere or usefuzness propriety wiI properly permit," whin "afiording to my

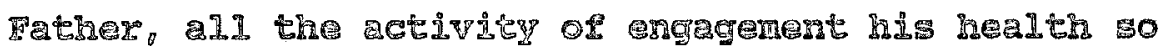

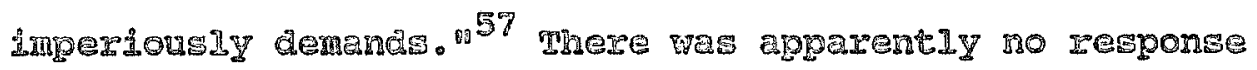
Erom Serara and there id no evidence cerroll evar bought: the sazm.

Carrol" ${ }^{\circ}$ Gonstare devothon to her improvident get beloved father soon faced another challenge. Whomar ging

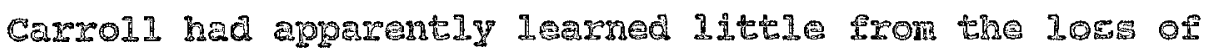

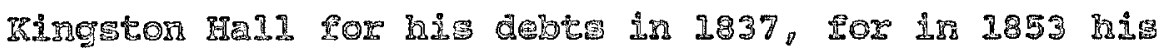
daughter begar to search for money to pay ors more or his debtw. 5re decholed mpor a mique conrse of action. St fargt

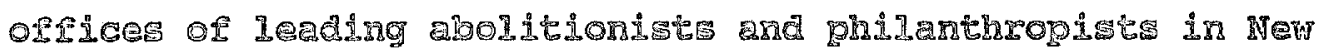

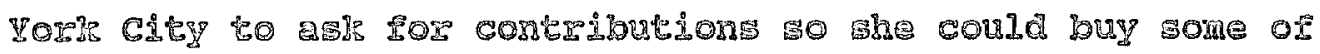

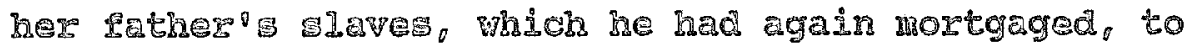
prevent their gale. While she continued to mrite lecters to men she thought wond bo mymethetic to haz plight, whe

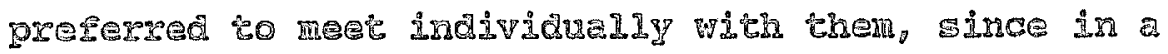
personal intervien there were many little suggestons \& explanation, orten Importent, to a corpect undesmtancing of

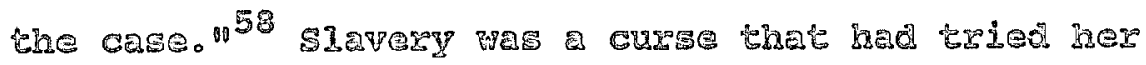


fortitude, she wrote Gerrit Smith as she applied for an interview. "I regard all my own misfortune-or that, in Which I am involved, on acct. of my family, to that Inheritance of slavery, to which for so many generations my family have been subjected. 59 smith made a contribution, as did IEV York journalist and editor Gerard HaIeGs. It wan HaIIeck who suggested she flumt convention by removing her veil when interviewing with people for contributions. ". . I thing it may rather operate against you " he mrote

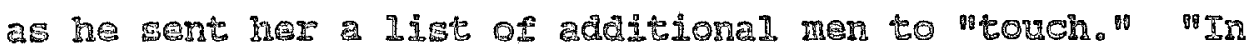

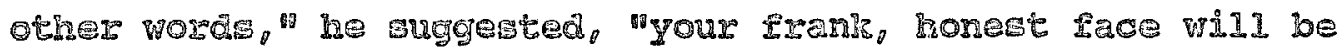
a passport to you where no mare name or family distinction 70uId be avaiding." 60

In combetion må hor

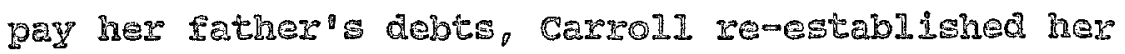

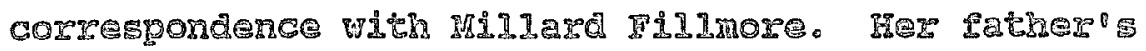
"generosity and nobleness or rature" had misguided his

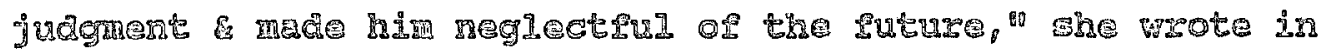

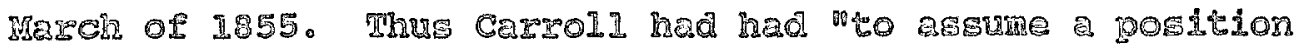

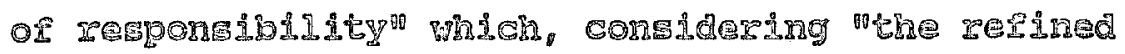

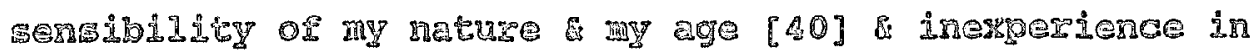

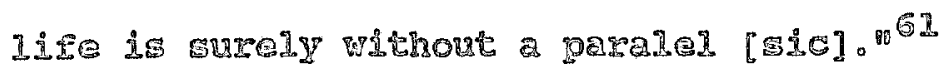

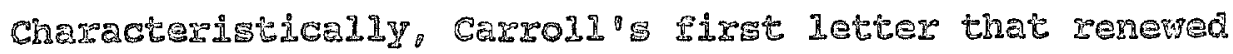

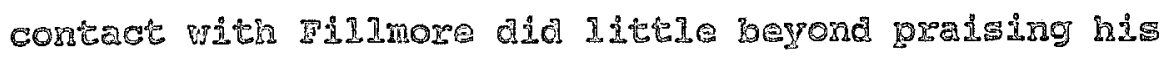

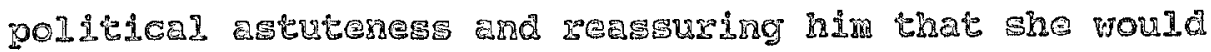

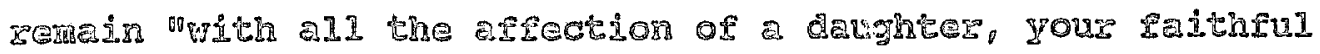


little friend. . . "62 But slowly and surely the demands began creeping into the text: first a complimentary one in the form of a request that he review the table of contents for a book she was to write, then a demand for an immediate response to that request. 63 A plea for a personal loan to avold eviction proceeding on her family followed, then a request that 38 call to wee her for "a purpose which you camot neglect \& will not regret! A1. these demands were made at a most inconvenient time, mhen Fillmore was absorbed

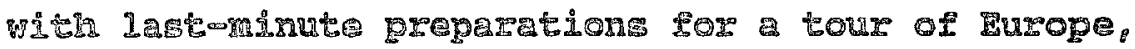
begining mey 16. Fe apparenty did not reply.64

Carrol $1^{\circ}$ : concern that Filmore reach her was not entirely belfish. Her anterest in politics had led her to an musul degree of involvement with the newly-Lormed Mmexian Bart. She wished to give Fow nomine for the 1856 campaign. "you may mile, she wrote Fin1more at 11:00 RH the ndght berore ne set sail, "but I believe, I can have very mush to do mith yr nomination by that garty, which will as wusely control the next election

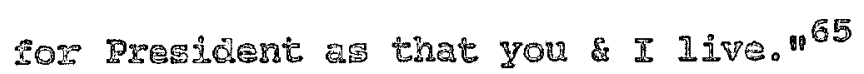

Cerroll told Fillmore that she had met with party 1emderg in Boston shorty after he malled and hed drafted a letter ror them that requerted he mare hit mesings \&

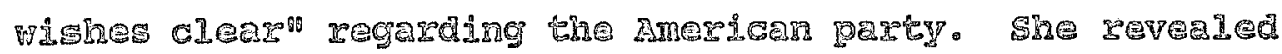
hercelr to $\mathrm{F}$ IImore as the author of the Ietter not for 
vanity's sake, but rather "that you may know the movement is sincere in good faith." 66 Filimore refused her request, taking a candidate's traditional position of reluctance that she accepted, but she enclosed the opening of a book on the Mmerican Party platform that she had written and asked his review of it. once he had zeceived it, she demanded, "write me a letter expressive of yx regard, for my efforti- I an so me11 assured, this will give you pleasure-m annot feel I impose a burden. ${ }^{867}$

Caryoll spent the mumer promoting the Amstican Party and Finmore as its candidate over his nearegt rival, George Law. Although she knew she was "a woman-and have no roght to interfere In politics," once again she found a way to excuse ner actions and meintain the legitimacy or her Worts as sine arguad that "thic Amerodean movement is above party and if the efforts of woman are ever to be exerted for

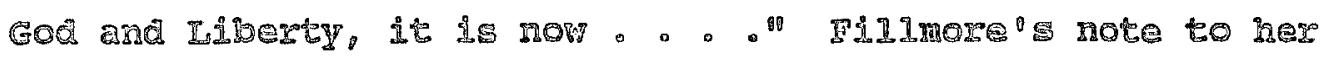

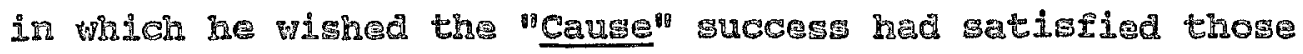
MnSure of hI: loyedty. Carroll was convinced of Filmore" Sultability as "My convictions as well as my nopes induce me to beliave you widl be the candidate of the American convention. Perhaps no one, valn tho it may seen, realyy Imow more of the true wishes of the leading men of ine order.. than Iny

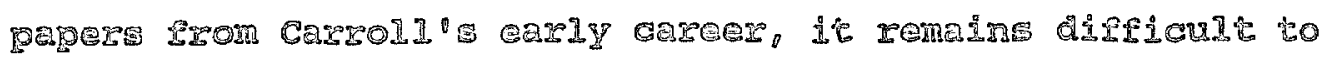

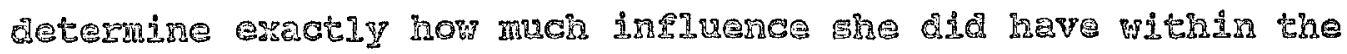


American Party as it pondered its selection for the presidential campaign. BY championing Fillmore, however, for one of the few times in her Iife, Anna Elle Carroll had chosen the right man upon whom to expend her inexhaustible ฐupply of Iiterary energy. 


\section{Notes}

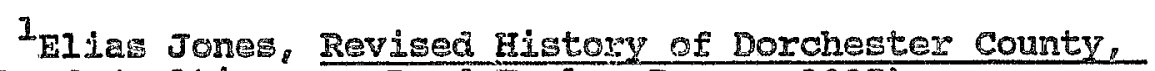
Iharyland (Baltimore: Readraylor Press, 2225), pp. 296-297; Appletor's Cyclopadia of American Biography, Qd. Jamus Grant Wilson and John Fisfe, 6 vols. (New Yors: D. Appleton and Co. 1886m-1891), 1(1891):536-538: Ama T11a Carro11, The Great American Battie, or the contest Betreen christianity and political Romenism (hereaferr referred to

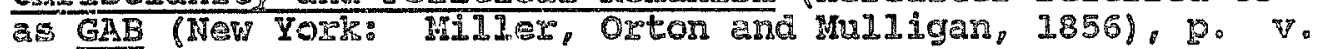

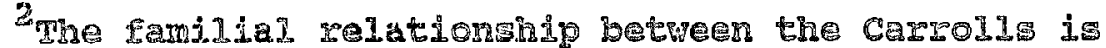
Aifricult to determine. Jones book on Dorchester county. to which the cerrolls moved about 1840 , is 185 then accurate concerning other data and therefore must be used

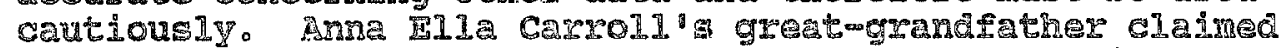
cousinmip to charles Carrold of Carroliton, a claim thus far undocumented. Carroll herself claimed a comon ancestry and mentioned the connection rich considerable pride and frequency, particularly when justofying her hovolvenent in activities outside the moman ${ }^{\circ}$ sphere. See Chapter 2 below. Letter, SelIy D. Prason, associate cditor, Chares Carroll of Carro Iton Depers, to author, 6 Decenber 1985.

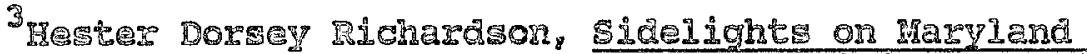

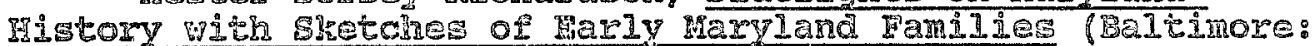

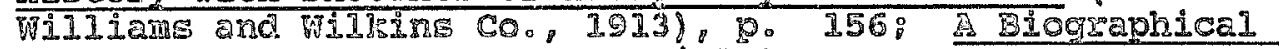
Dictionary of the Mexyland Legis lature, $1635-1789$.

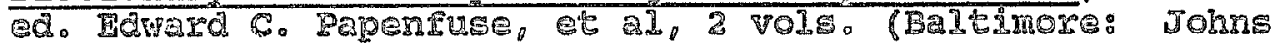

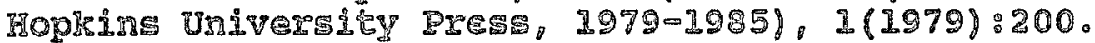

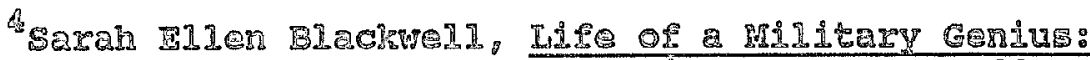

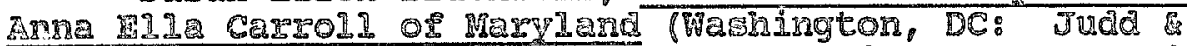

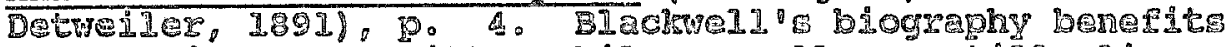

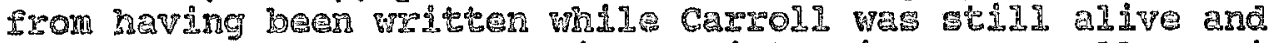
con'd provide the athor wish an incerviow. Carroll was in poor bealin, however, ano evidence intigates most of the interviening wa conduesed by note-writing and through Carro11' 1 : ister mary, who took care of Carroll during the Last yeare of hez Iife. Most of the biographldal

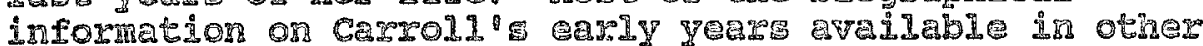
gourres appears to bave beers talen from details provided in

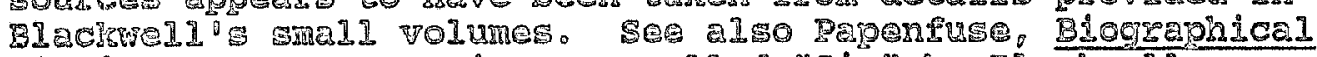

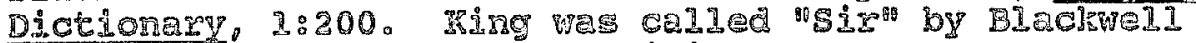
probaly due to a canily traoition. 


\begin{abstract}
${ }^{5}$ Blackwell, Iife, pp. 5-7; Jones, Revised History, pp. 297-298; Biographical Directory of the Governors of the United states 1798-1978, ed. Robert sobel and John Raimo 4 vols. (Westport, CT: Meckler Books, 1978), 2:659; Newspaper cijpping enclosed with Jetter, Anna Ella carroll to James Abram Garfiela, 11 september 1880, James Abram Garfield Papers, Library of Congress, Washington, DC:

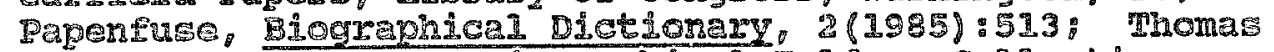

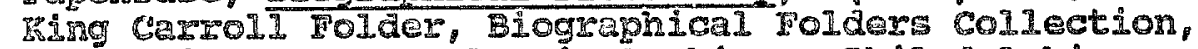
univeresty of Bennylvania archives, Phlladelphia, Berang?
\end{abstract}

BIackweI, Infe, 10.9. Although several sources

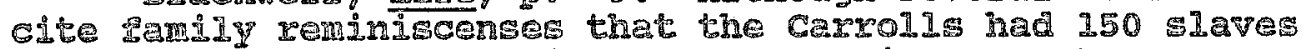
at Inings:

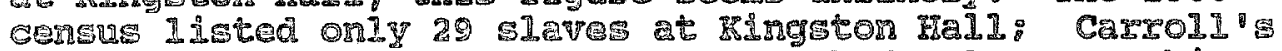
faster, Colonel Henry Janes Carroll, had ond 14 on his estate. colonel carrol1 was mot 1 lsted In the 1810 census

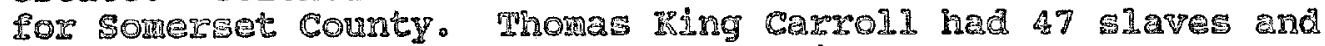
4 Iree black mases at Kingston HaI in 1820. Whe 1830 census I0r sonerset comty hes apparenty not survived. Given the small number of young slave chìdren in the census of 1820, there were probabiy about 45 mines miner carrol1 received his inheritance five years eariter. 1800 census

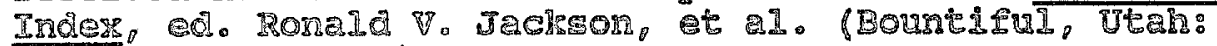

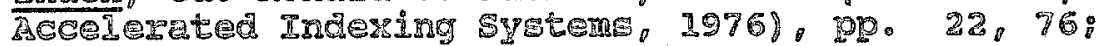
pooulation schecule of the maine cenave of the united

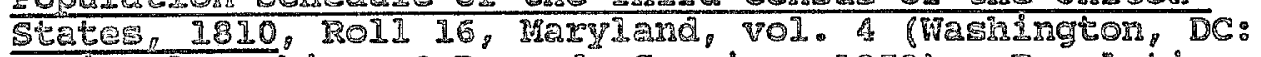
National Aresives \& Recorde SExvice, 1959: Population

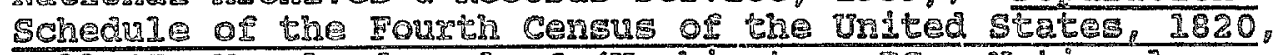

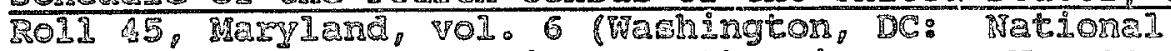

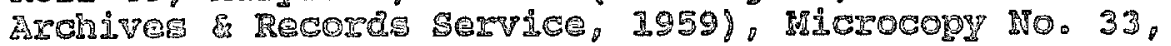

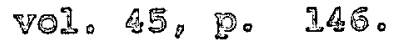

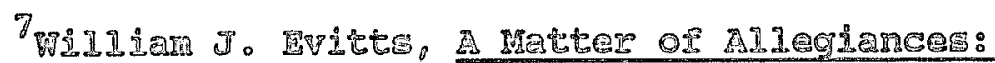

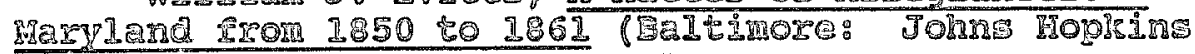

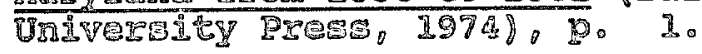

8 Jom Hope Franim, From SLavery to Frecdom: A

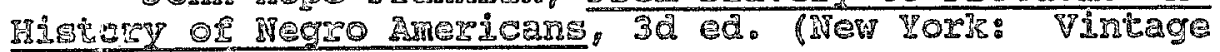
10018, 1969): 290.75, 340, 151.

9.

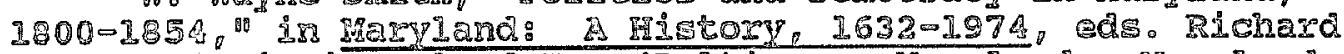
Wa1sh and . Historical Society, 1974). 90.282, 243.

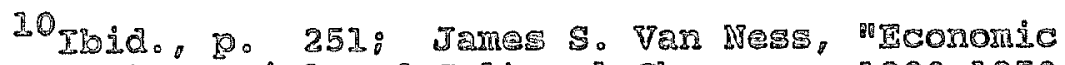
Development, social and Cultural changes: $2800-1850,1$ in

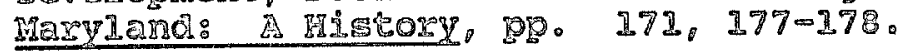




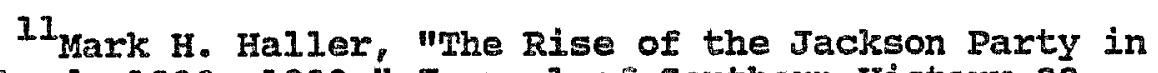
Maryland, $1820,-1329, "$ Joumal of Southern History 28 (August 1962):309-310.

${ }^{12}$ Ibid., pp. $311-312$; Harper to Haxcy, 1 March 1824, cited in Haller, "Rise of the Jaclsson Party," n. 21 .

13 Congressional guarterly, Gudde to U. S. Elections (Wasnington, DC: Congressional OuanterIy, InC. 2975), 10. 225, 265: HaIIer, "RIse of the Jacison Darty" DP. $318=329$.

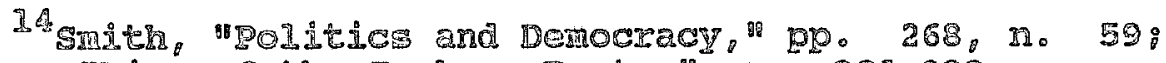
Hellez, "ris

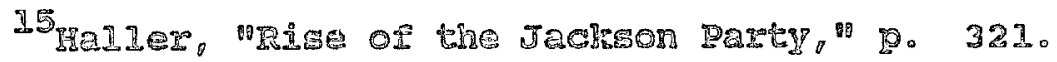

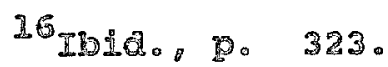

17 Tereentenery history of Maryland, compiled by Hensy Flecher Potell, 2 vols. (BaItimore: S. J. Clarlse Bub. Co., 1925) 3:768-769: 4:47-48: James E. Fitrgerald Brewer, orhe Democratigation of Maryland, 1800-1837, in whe 0la Ine State: A Ristory of Maryland ed. Morrds

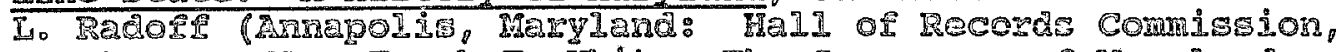

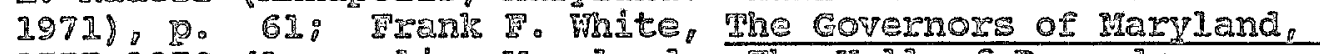

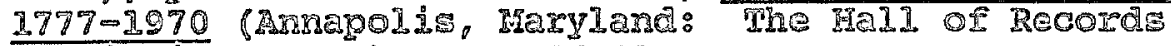

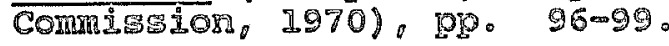

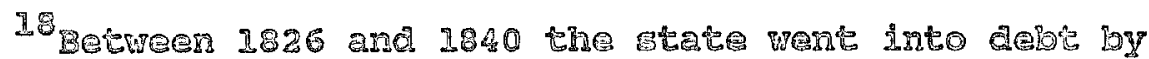

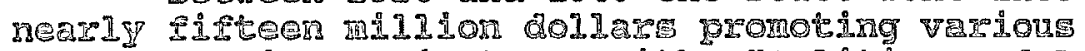

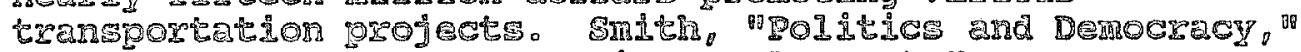

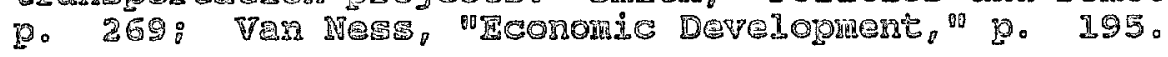

I9pits, The Governors, PP. $20-99$.

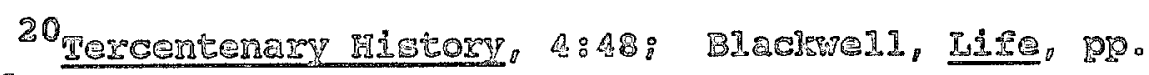
$25-26$.

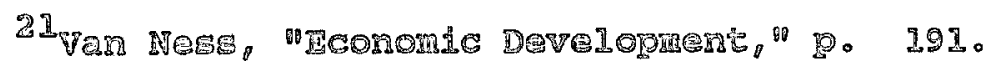

$22_{\text {IBId。 }}$. 297 .

23) I0Ld. 9p. 189-190.

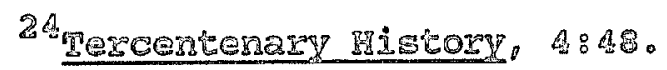

25 Richardson, Sidelights, Pr. $35605 \%$ 


\begin{abstract}
${ }^{26} \mathrm{p}$. J. Staudenraus, The African Colonization Novement, 1816-1865 (New york: Columbia University Dress, 1961), p. 70. For yearly reports on the Maryland state Colonization Society, see African Repository and colonial Journal, 68 vols. (n.p.: Kraus Reprint Corporation, 1967). Denelope Campoe11, Maryland in Africa: The Maryland State Colonization Eociety, $1831-1857$ (Urbana, I1Iinois:

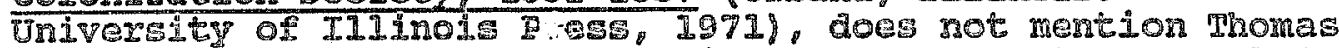

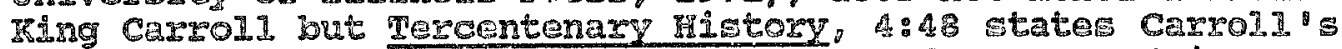
promcoloniation position. See also staudenraus, African Colongation, Pp. $70,111$.
\end{abstract}

27 AnY farndy information about these carrolls is dispicult to obtain and difficul to verify. Ses mana EIIa

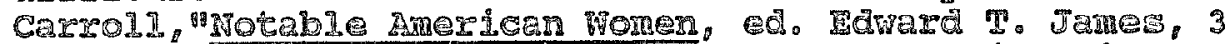

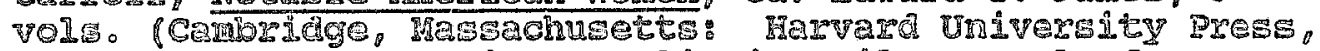

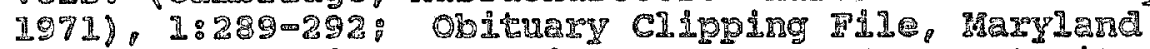

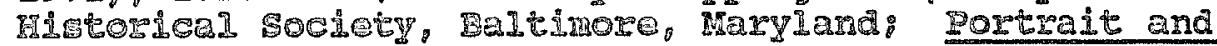
Biographical Record of the Eastern Shore of Maryland TNerg

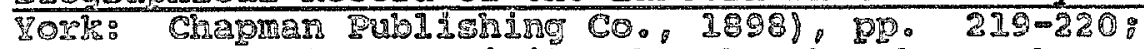
gravestones at old printy church, Churan crear, Maryland.

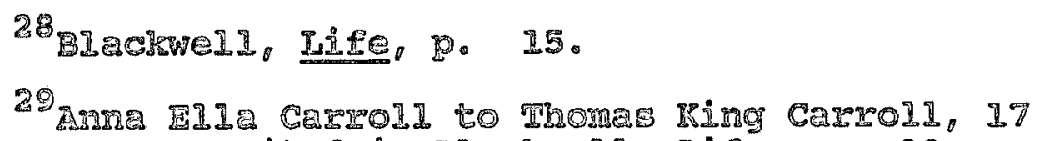

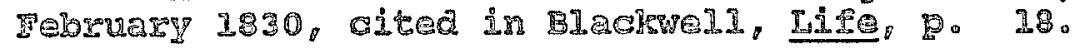

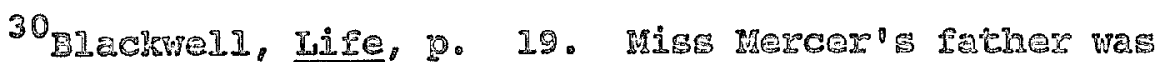
Maryland governor John Francin mercer. See Janes Irezcer Garnett, "John Francis Mercer, Governor of maryland,

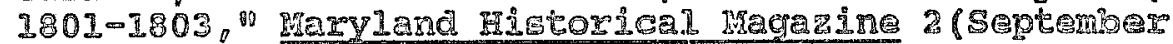

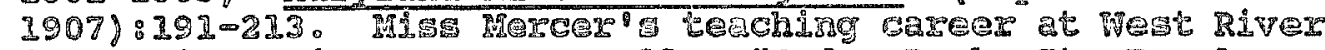
i. mentoned In J. Reaney relly, "Cedar Park, Its People and

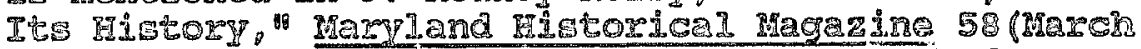

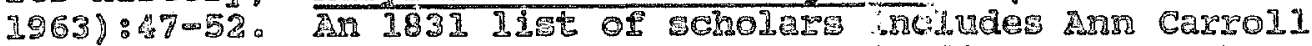
and Ju1 Carroll among those from majyland Presmaby thi.s

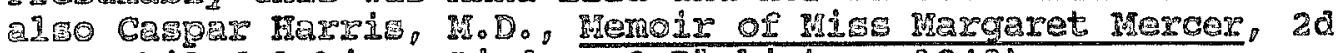

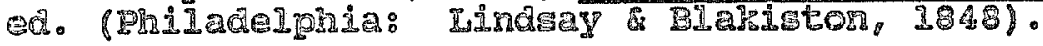

$31_{\text {grem }}$ Loris alergyman the Reverend Dr. B. Spregua promented this raling porterit of a wonan's function in Iife in typech at the Packer collegiate

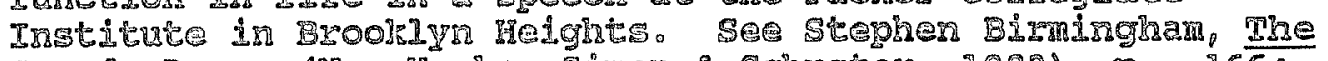
Grande Dames (New Yor?: Simon \& Schuster, 1982), P. 166:

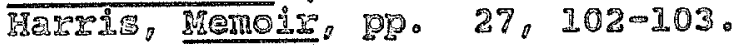

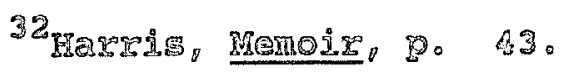

$$
\begin{aligned}
& 33 \text { Ib10, PQ。 } 123-114,130-133 \text {. }
\end{aligned}
$$


${ }^{34}$ Blackwell, Life, pp. 25-26: Anna Ella Carroll to Gerrit Smith, 26 June 1854, Gerrit Smith Collection, George Arents Research Library, Syracuse University, syracuse, New York: Tercentenary History, 4:48.

${ }^{35}$ Somerset County Chancery Court Records, 21 January 1836, Somerset County Deed Book, 19 october and 29 December 1835. Maryland state Arehives, Hell of Records, Annegolis, mary Tand.

${ }^{36}$ Jones, revised History, p. 298: Blackw11, Ihfe,

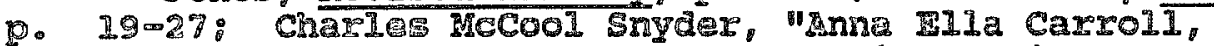
Politices strategist and Gadily to Iresident Fillmore" rerviand Historical Magarine 68 (spring 1973):37: white, The Governors: Do 99: Baur Touart (Architectura

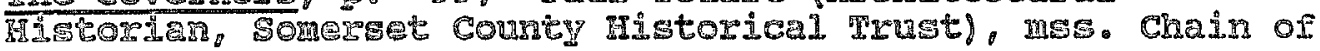
Titele to author, 25 June 1986.

${ }^{37}$ Manerican Directories Throwgh 2860 (New Haven, Connecicut: Research Pablications, 1969 [?]), a microriche

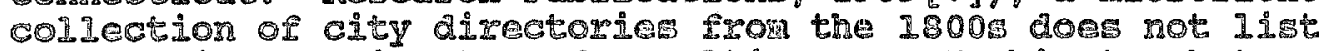
Carroll in any directory for Baltimore or washington between 1837 and 1850. Carso11 was member of the second Presbyterian Church of Baltimore in 1845. Dorothy F。 Miliger, church segretary, to author, 20 November 1985. SEe also chapter 2 note 8 balow.

38 Backwel1, Iife, $13-24:$ sed also the ramily

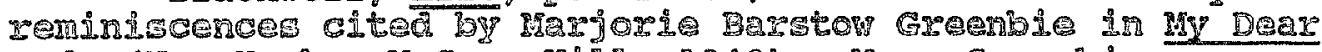

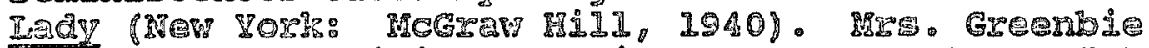

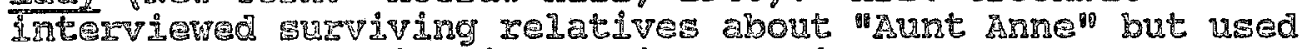
considerable poesic Iicense in her biography of carroll. Irer bools ranst be used with grat caution and considerable

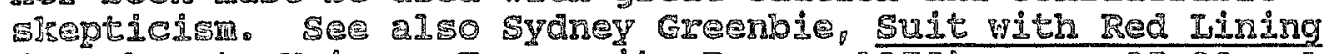

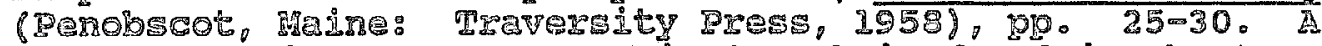

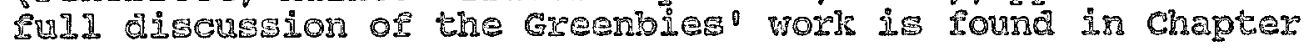
7 .

39 Dlackuel called the Gas a compitation of carroli's

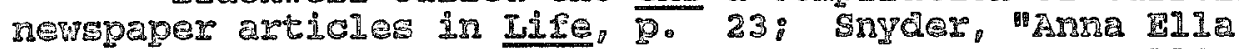
Carro11, 9.51 . 5aYs the same of mother or carzold's Dools, The Star or the West: Or, National hen and National 1 easuges. 3d. edition (BOSton: James French \& CO. If5\%).

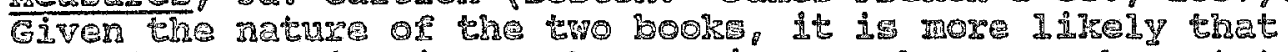

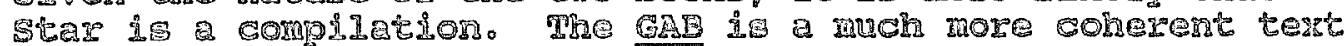

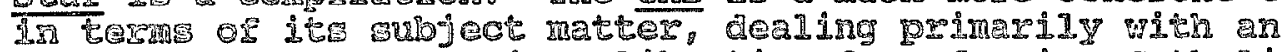

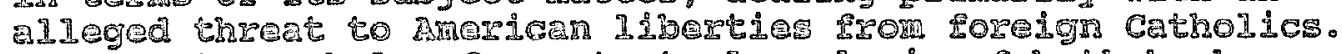
See Chapter 2 balow 201 a trastral analygis of both books.

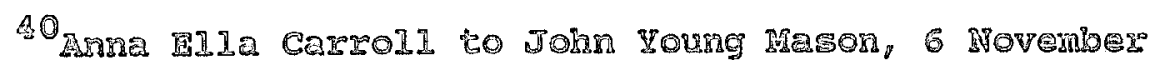


1848, Mason Family Papers, Virginia Historical Society, Richmond, Virginia; Blackwell, Iife, p. 23. Date of death from Julianna Carroll's gravestone, old Trinity Church, church Creek, Maryland.

41 Write, The covernors, pp. 99, 129-133: percentenary History, 4:48: Anne Tlia Carroli to John

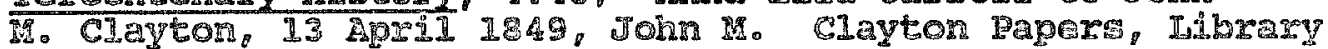

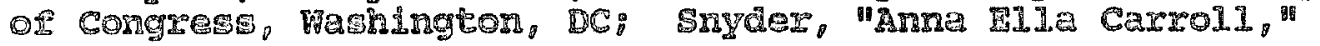
38. 38.

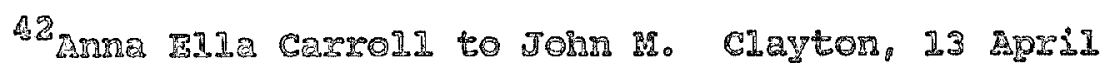
1849, Claytor Rapers.

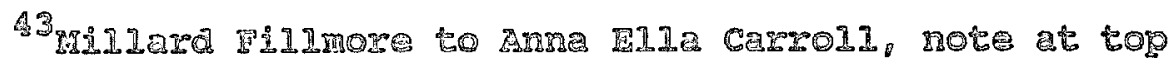

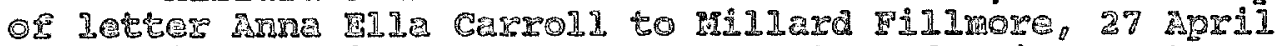

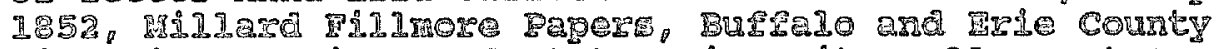

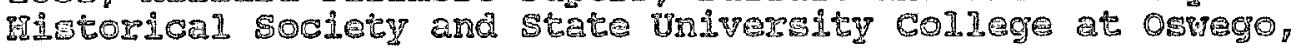
Ostrego,

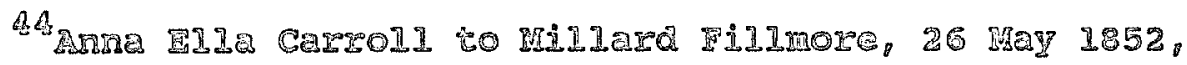
Fillinore Papers.

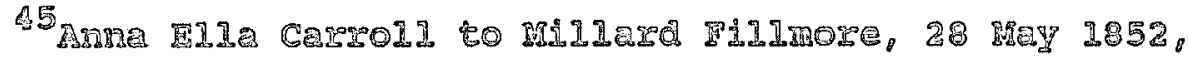

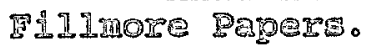

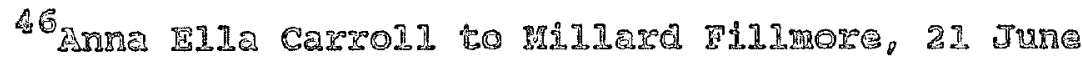

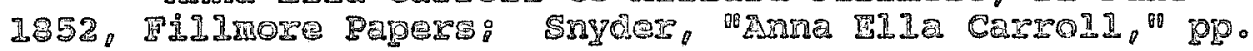
$38-39$.

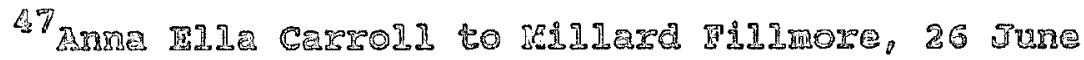
1852, TII Irore gapers.

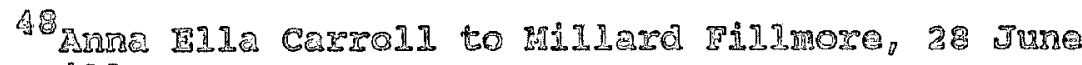
1858,

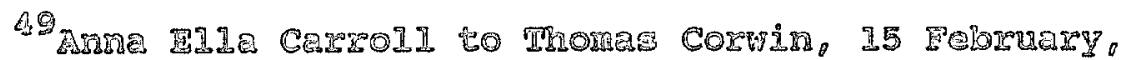

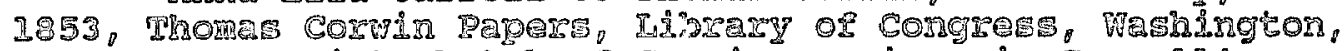

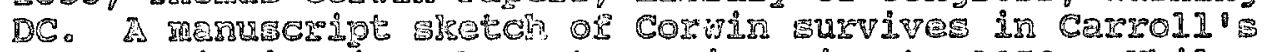

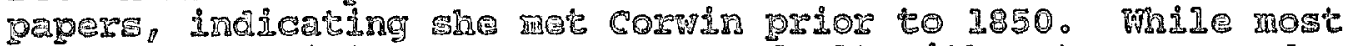
OI their wurwiving cozrespondence dealt with patronage and political matters: one lecter Bron Corwin in particular gtand: ort as a cestament to the intrimay of their friendship. He sadiy reconged to her that he was a failure

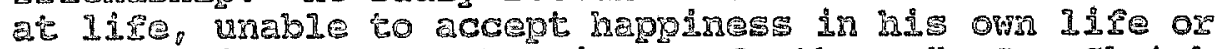
manifest joy "at the heppines: or others:" see s7setch:

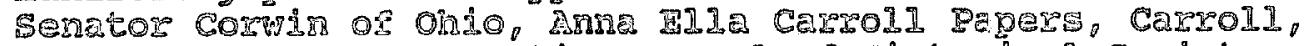

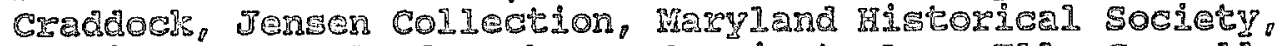

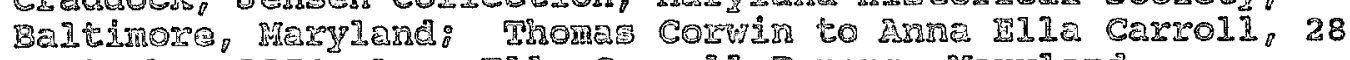
Seprember 185, Ansa TIIA Carroll Pagers, Marmiand 


\section{Historical Society, Baltimore, Maryland.}

\section{${ }^{50}$ Anna Ella Carroll to Millard Fillmore, 7 March} $1853_{\text {, Fillimore Papers. }}$

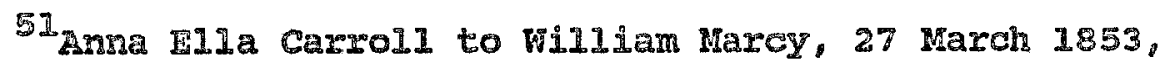
W11Lam Ioarned Harcy Papers, Iibrary of Congress, weshington, DC.

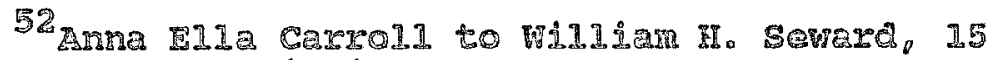

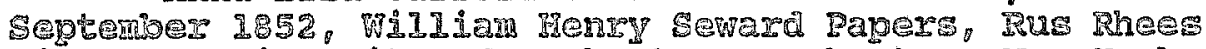

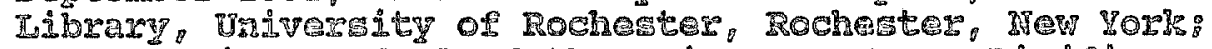

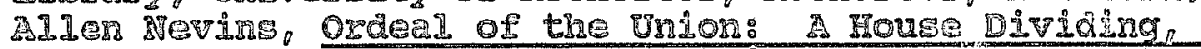

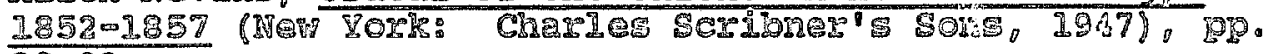
$23-32$.

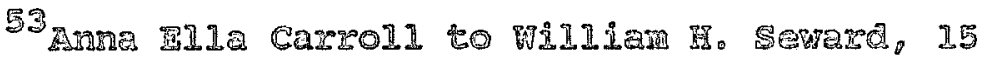

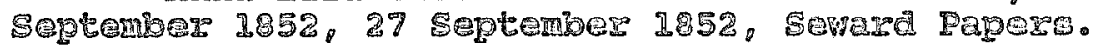

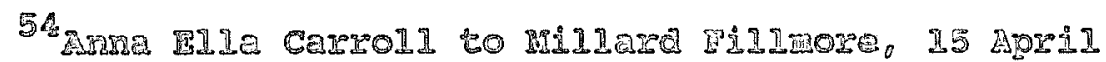

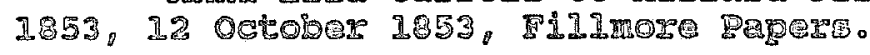

55 2Arma 1953, Seward Paperis.

56 2 ma III CarroI1 to 2853, Seward Pegera.

57 Ansze 1853 , 56.

58 5xitr COLIecion.

59 IDI‥

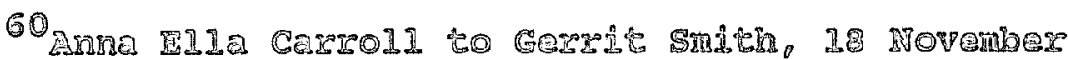

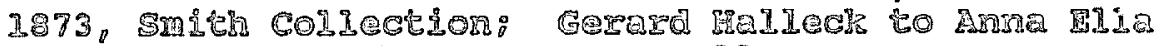
Carrol1, 19 Degember 1853. Carroll Papers.

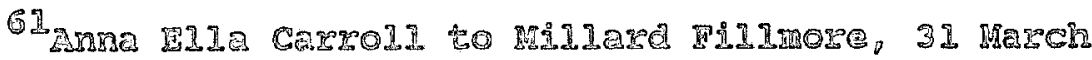

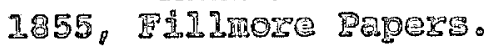

62 Iอำ.

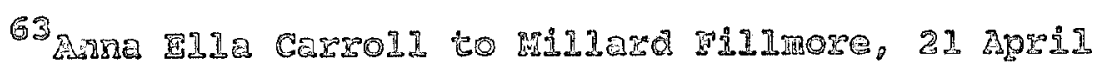
1855, 23 Aprill 1855, Fil1more Pegers.

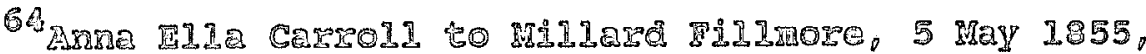

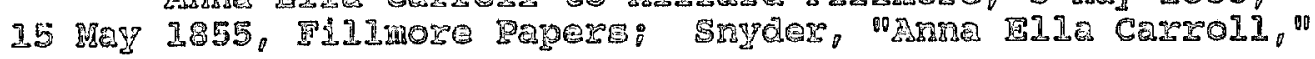


pp. $42-43$.

65 Anna Ella Carroll to Millard Fillmore, 15 May 1855, Filimoxe Papers.

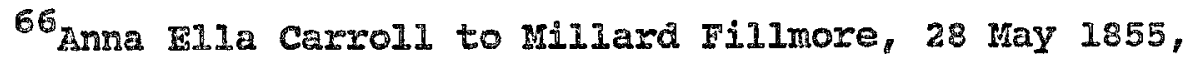
FIImore Papers.

67 Mna Fla carrol1 to PIIIare Fillnore, 7 July 1855, F11.more Pagers: Snydex, "anne Flla Carroll," $p .44$.

69. 1956. Fil1more Peper. 


\section{Chapter 2}

\section{Carroll and the Election of 1856:}

\section{The Revulican Mother is Savior of the Nation}

Miำard Finlmore was nominated in February 1856 as the Anerican Party ${ }^{\circ}$ gresidential candidate. Carzoll was convinced that it was thanks to her: after ald, she had แeer a suporter of FIInore 25 far bacls as 1852 . How at last, her cholce was legitimized by the men of the paxiy. and Garald had been given a nationa: platform from which to write. While she continued her private political activities of seeming induance over peronage position through her letters to politicians, she mon began to publish under her Om name and bo participate in wore pubic political behavior. The next elght months monld be the most productive of Carrol. ${ }^{\circ}$ career as she wrote and published bools, pamphIets, articles, and editerials in support of the Arergen Party and its candidate. The zise or the Mangicar Party to national power 
after 1854 came about as the Whig Pasty declifred and paralleled the rise of the Republican Party. Both new organizations appealea to voters, primarily whigs and anti-glavery men, who mere disenchanted whin the compromises inherert dn a retionel two-party gysten. Both orgmadations

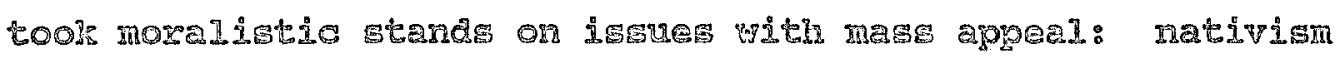
and ant-Catholicign, and the control of slavery. nany mativicts mere also anij-sLavay men anc vice verse, and voters supported one or the other party. or both. put by

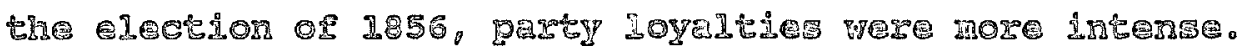
ronownotsings were determined to win the election with a

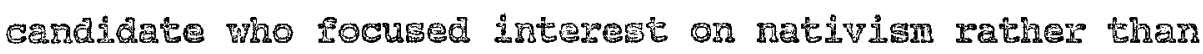
silavery. 1

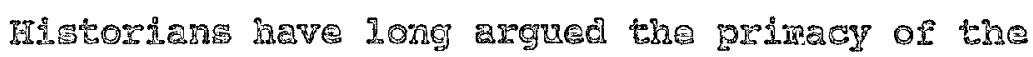

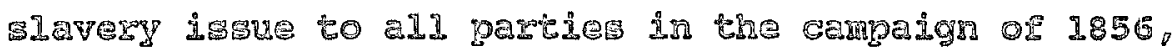

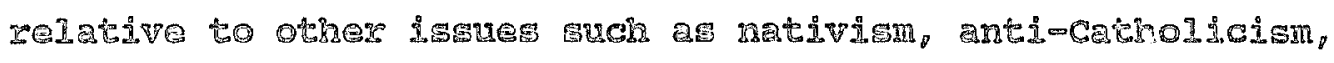
cemperance, and economids. Frmaninatons or poting records

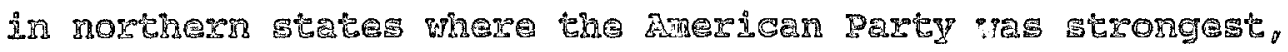
however, have emonasized that the majority of Rnowmothings

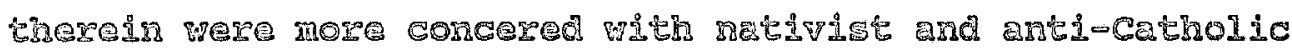
iswer then with the antosivery movement and its radical

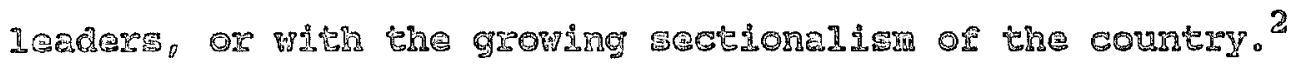
Far from being a party or displaced whige former Locofocos.

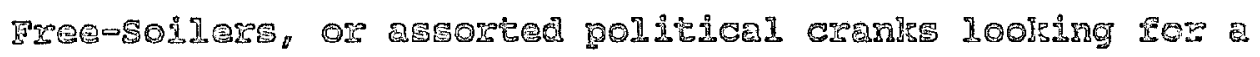

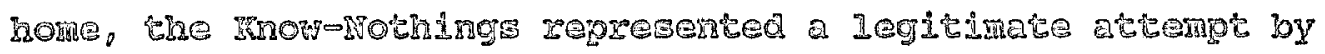

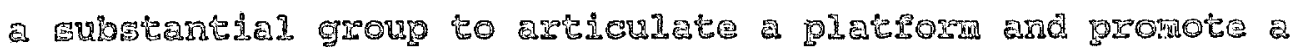


party that would respond to their fears. ${ }^{3}$ know-Nothings perceived a growing threat to the American nation by the influx of foreigners who were primarily lower-class, guickly naturaliged, largely controlled by the Democratic party machine, and neld responsible for the growing corruption and dissoluteness ajsemible in the merican body politic." For the Amercan Party, that threat was far more importent thas the issue of slavery expansion or control.

In the border state of Maryland, as in the more northern states, corruption, nativism, and anti-catholicism were the major concern of the Rnow-nothings, is apite of May Iand" status as a slave state. These were the issues that attracted the majority of supporter: few exprassed great concern over abolition and the alavery guestion. 5 Carrol, POr Instance, had mbraced the Amerdoan Darti for a number of dfierent reasons. Her father had been a whig supporter, as had she, and both sad been aisheartened when

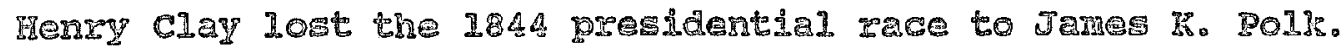

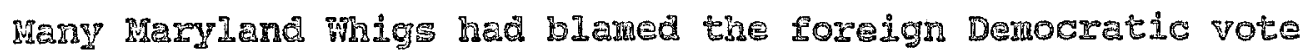
in Baltimore ror helping to give Poll the victory, even thongh maryland had gone mig in the election and the margin In Faltimore rad givers POIJ a plurality of only 473

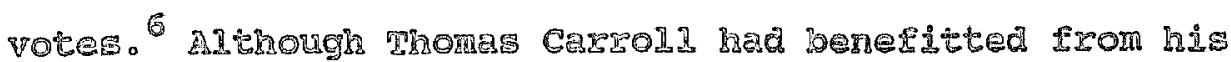
Whig patronage position in 1849 , by 2.85 the whigs were out a a decline by the mid-18505 made the Inow-mothings an 
attractive, non-Denocratic alternative. 7

An additional influence on Anne carroll's political choice was the Reverend $\mathrm{Dr}$. Robert J. Breckinridge. Brechinridge, minister of the second Presbyterian church of Battinore, which carroll had joined in 1845, was a powerful orator and an ardent ant-Catholia. His tirades against roreigners and catholics made a deep and long-lasting 2.mprassion on Carrol1: twenty yearg later she would recall Ris sermons as she mrote to hin of her Iifo"g work on behalt of the ant-Catholic movement. Breckinxidge, Iike a mumber of other Protestant ministers and leaders, was more bnan wiling to use the government to accomplish the anti-CathoIje goals of the know-bothings. Rivalry between Catholics and Protestants ln Inaryland was nothing new. By the $1850 \mathrm{~F}$, It wa caused by Imigration, by political cormption, by the

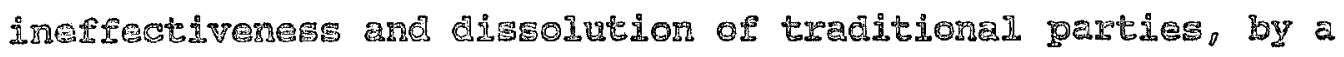

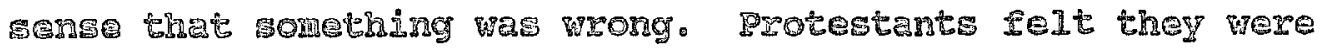

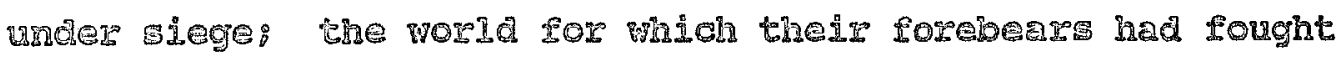
and mormed and aำ not Dlame themselves, they looked outwide themselves and 也heir Protestant cultural matrix to the forelgness, to Iำoming congug, cheir difrerent values, beliefs, anc cultural gystem. Foreigners became an easiy identifiable enemy." If foreigners coula be menies, foreign Cathollcs 
could be doubly treacherous. Not only did they represent a threat to "Americanism" by retaining their old country ways, they represented an additional threat by their allegiance to a foreign potentate, the Pope, who, "sitting and trembling upon the great shield of the Vatican at Rome, Supposedy " and cemporal interests of this yourng world. 10 whus had the Ifrownothings, In a classic ezamplo of paranoid political behavior, leapt from tre undeniable that politics were compre and society in disarrag to the unbelievable

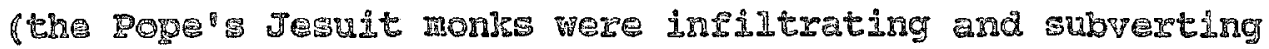
tre American political system) - Know-Motinings ielt thet their acces: to the political process was being threatened or linited by foreigners. considering their politically

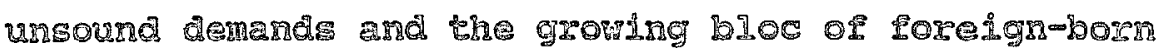
regintsaed voters controlled by pary bosses, thedr sense or porerlessness was not entirely unjustified. Eut their lack of political control พras parceived by them as a masmre of an anery ${ }^{\prime}$ power that had been achieved by conspiratorial

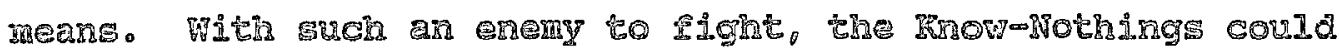
unite as a true political party. But grounded on amotional rether than rational approaches to the ismues, the American

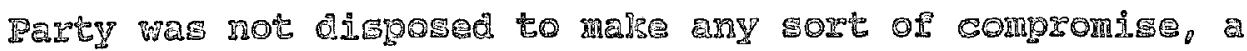
stand that in the troublewone $1850 \mathrm{~s}$ meant death to ordinary

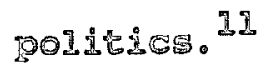

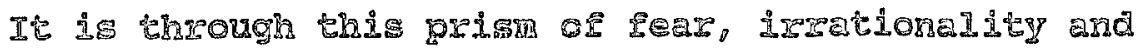


emotion that characterized the know-Nothing Party that its Iiterature must be evaluated. Know-irothing writers, Carroll Includea, were not only convinced of a Jesultical consplrecy, thay were, lifse most missionaties of a cause, convinced of the righteousness of thejr om position.

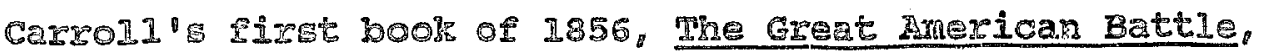
could be vigned as an American Party Bible, so accurately dia it portray the Party and its ditates. Iilse most

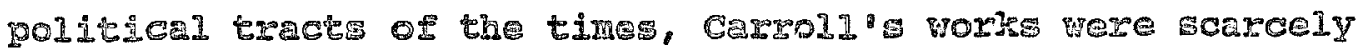
Iiterary masterpieces. She tended coward overdy dramatc prose, hyperbole, dtalles, and exclamation points. Sti11,

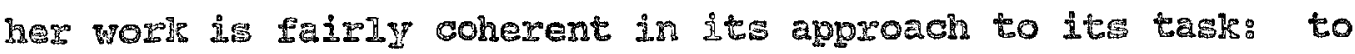
state che danger and propose approprdate action to

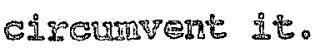

The Great Mmerican Battle Gan be divided Into three major secton. The flrget Womm, men, and children, along with the Pross, to the

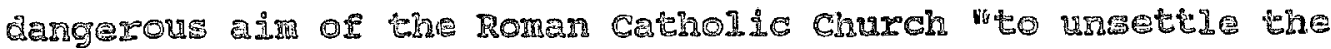
principles of our Mhberter and Mence to destroy them... " ${ }^{12}$ moman "s tasp was to perceive the danger and act upon it, "but only as a moral agent" even though her

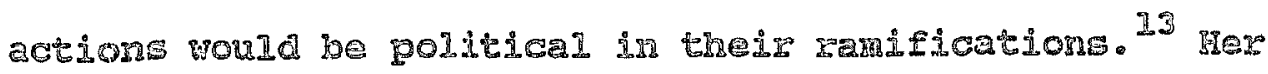
grovince was the education of childrer and of men. By this

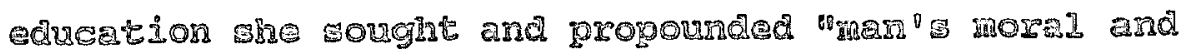

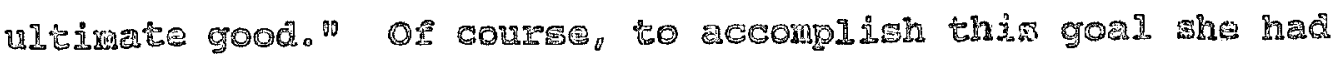

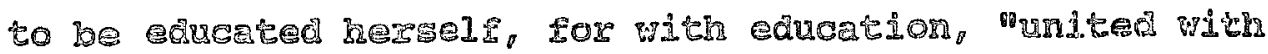


mozal power, she becomes an arm of strength to free America."14 In hex call to woren, Carroll combined all the characteristics of victorian culture: the high status of the mother as the transmieter of cultural identity and values, faith in the redemptiva power of education over ignorance and sin, and the imposition of the protestant christian framework upon extant Institutions, thus reforming those ingthtudons to reflect more closely God's will until that version of rif $^{\prime}$ vil1 would "govern the mind of America. 1.5

The tasks of the Press and the men of America secred Ins noble by comparigon. While the "Women of America now may be said to concrol the destinies of ages yet mborn! bocause of bheir iniluence over children, the Iress was primarily urged to tahe the subject seriousig. ${ }^{16}$ An the "yugement-seat of public opinion" its alsmiswal of American Qarty fears as "fxpolous" could result in its ow destruetion, warned Carro11.1\% Men of Anerica, on the obner hand, mere by the Jeruit threat afforded a perfect Qpportunity to emulate patriots of old. To ma, as to women, educeton mas the kay to mesting the cuisi: "the Ingtrument of liberty, property and security to Mmerica.

The eductional process cerroll called for had to be one that did not involve the uge of Catholde gchools, populats in the United States For their ragorous currdculum. 
Such schools posed a significant danger since education nourished "the very soul of America."19 The Catholic church offered education as a way to influence and eventually control those souls through convents, schools, and colleges, she argued. 20 The school issue was a particularly touchy one for rarylander carroll. In 1852 , Delegate Thomas IRemey of BeItimoxe had Introduced to the strate legislature a school reorganization bill designed to simplisy the admindstration of state-funded, 10G11y operated Bchools. The bill made provisions to give state aำ to private (inciuding parochial) sahools is their Curziculum was statemapproved. In practice, the bill would have meant public Bunding for catholic schools.

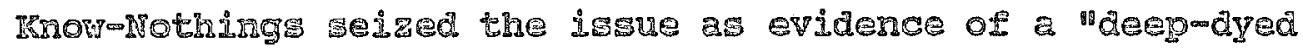
Popish plot" designed to negate kraditional separation of

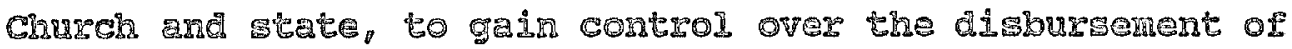
educatonal funds ftheir nezt step, no doubt, vas to seels

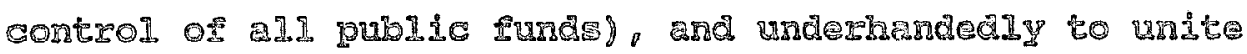
church and atate into a theocratia government answerable only to the POp. ${ }^{21}$ Comming betwern her Lather's residence in Baltimore and her om work in wasington,

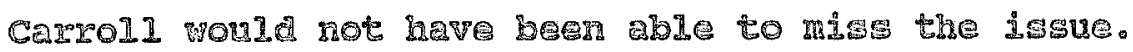
The Dh1 wes evertually buried In leginlative

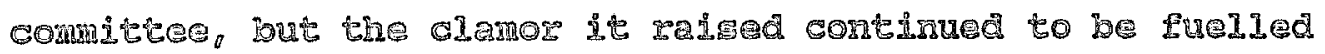

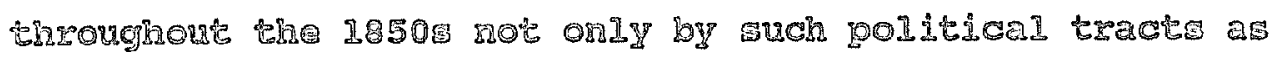

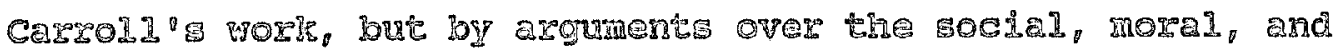


political implications of using the Protestant Bible in public schools, or banning the Bible entirely at the request of Catholic bishops so Catholic students would not be exposed to it. Censorsing by the catholic church over reading mettex in school sontinued the controversy with moxe protests by IRownothings IIIs carroln who thought that history would thus be "murdered and Iiterature "maimed and rateigatec 22

The most imous of Catholic eductors, or course. were the Tesult: and this special branch of the catholic priesthood came In for the nost virulent attack by carrol. Through education "the humble or our Iand save bes made 101ty, the poor save been entiched and blessed ${ }^{\circ 3}$ and she

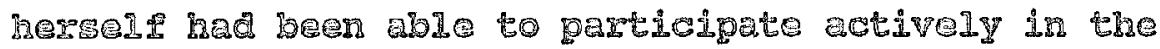
polthiตal word

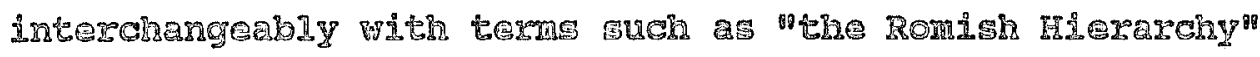
and "Popery " by comupting chidren in their schools, was "1

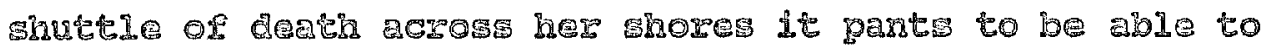
rater its rteed in her great metwhor: aside, the Rmerican Party had been formed. declared Garrol, to Forestall this Jesuitical takeovar.

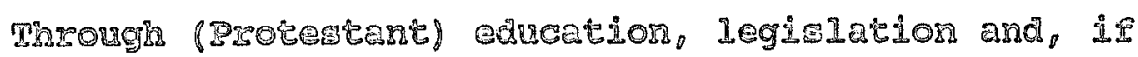

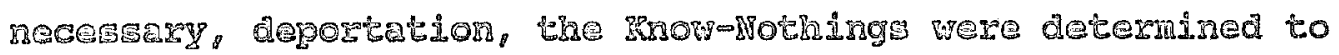
Qereat the ros.

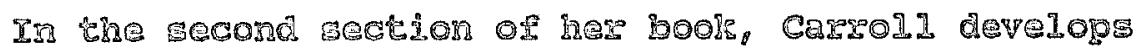


the literary device of a garden tea-party at which America and his mother (never named) visit with each other and friends and discuss the history of America's birth and rise to manhood, as well as the enemies that will assail him once he leavas the [Americany party. Day by day, chapter by chapter, Amerdice and his mother discuss the nature and Graracteristice of the American party: comparable to the "Iiberty Party" ô the Revoluthorary period, 25 secretive only because it needed tine and trustworthy pary mempers to guarantee solidity and strength of oxganization, 26 opposed to the (5210 of public Iands to inmigrants Instead of to Mative American citizens for pubic improvenents anc the education " $^{27}$ me Union ${ }^{\circ}$ netond interests and its preservation ver: more important than any jectional gein. The 5poin

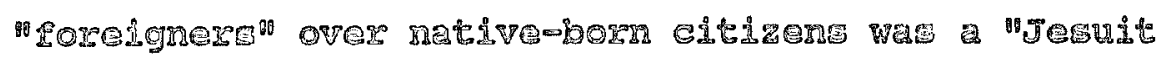
2nchendim to tare over the country. 28 mo met those

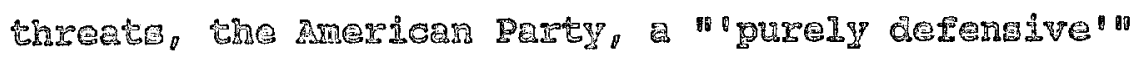

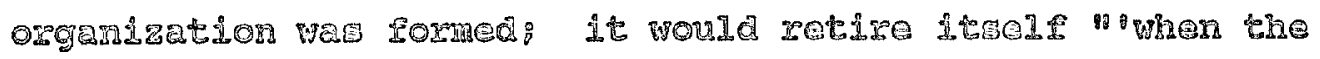
aggression of roreigners ceases.

In Iise manners, Carrolt continued for many pages, presenting the Amerdean Party stance on a.1. the major political iswes of the day and barmbing the reader with her accusetlons ageinst the mtmid, servile serpents or the

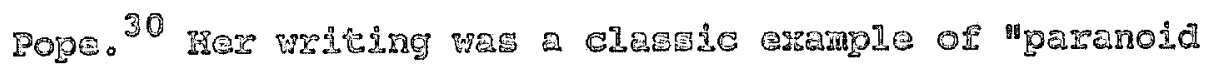

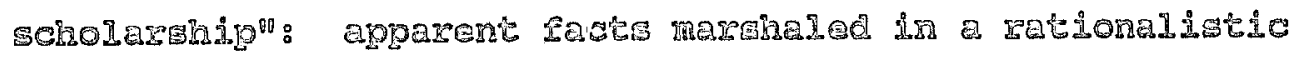


and scholastic manner that led to a conclusion neither rational nor scholarly. ${ }^{31}$ Carroll brought in the history of European monarchs condemned by the Pope to prove the papal interest in controling temporal matters. She discussed the Incles of Pxohibited Books and the Inquisition to prove the catholice" attempt to restrict freedom by controling minds.

In the last section of ner book, carroll brought the troubles caused by thi: supposed Papal conspiracy to the present day. She accused the Naval Board of Fifteen, which had reorganized the savy officex Iine in 1855, of being controlded by the Jesuits. The zeorganization nad been controversial and several officers had mritten carroll complatring of their reserve status. She took up the canse and found the "proof" of conspirady in the catholic backgrousis of Senator stephen A. Mallory, who had introduced the original bill of reorganization, and of board ramberm Comander Samul F. Dupont and commodore w1111am Shubrich: 32 mhy wond the Pope went to use these men to destroy the American navy ( the reorganitaton)? For the same reason se wanted his subjects in patronage positton: it was "to sap the foundation of on democratic Iiberty and our glorious Constitution, ${ }^{\prime}$ as meIn ag to destroy the only arm of the United states" government that conda conceivably interfere in the crimean war. Chronology aside the war ended just 
before the book went to press), Carroll was convinced of the Pope's desire to crush Russia and the United states somehow so there would be no rival to the Pope's European base of power. 33

In the end, carroll called for the expulsion of all Jesults and the canceldation of all treaties with countries which would not allow the fres practice of protestantism. And, of course, all true patriots shoula join the Mmerican

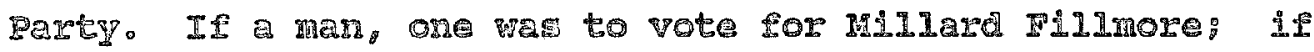

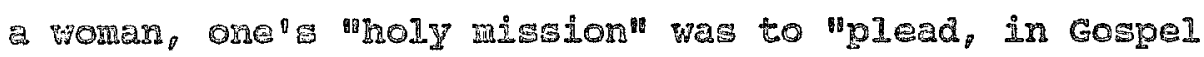
Birmedrty and patriotic Lervor with the men or Mmerica to vote for FiImore, thus preserving "our Sabbath, our Schools, oxr BIDI0 and Liberey. $0^{34}$

Beyona a wtatement of Amexican Party principles of the moxe moderate wing of the Knowmothings 1 Carrong did ajfererentate between foreign and native-born Catholim:

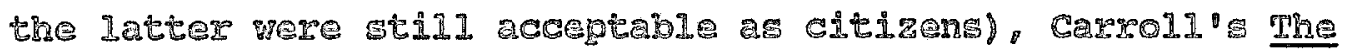
Grat ame provider regarding her wiews of women's place, women's worle, and of her consGLonsness of the bocietel strictures pImed upon her. Caroll began her woxk by apologiging for her intrusion inco the mascrine world of politice, protesting

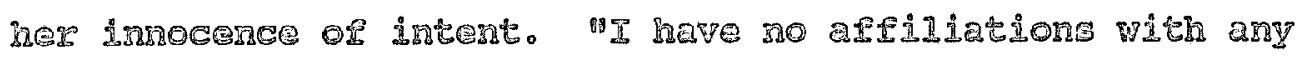
principle: which place [Woman] in a sphere ar vaziance rish

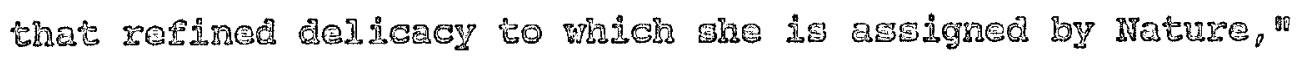

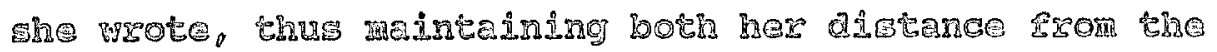


burgeoning woman's rights movement and the individual nature of her work. 35 she had "no aspirations to extend her influence or position. "36 Yet the present dasgers to the survival of America meant wowen could not shrink from their duty. "God has given to woman to enlighten America, and to Amexica to light the worda. . ." Merdea" fate depended on "the work of America's deughters."37 mile this was a "high politicel mission," carrold again reassured nes" readers that it was only as a moral agent that women should

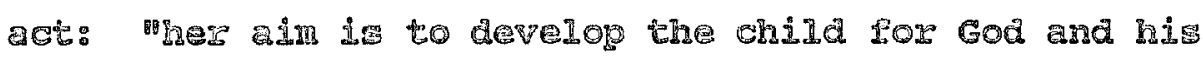
country $: 38$

This ideology of the regublican mother, common in the midminetenth century, and the portrat of the morel

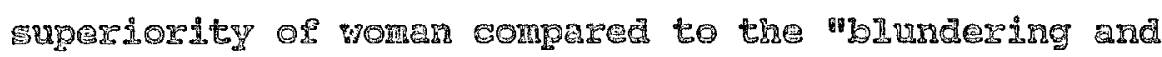
guarre1139 of men"39 recurred throwghout The Great

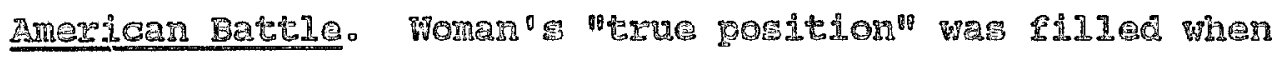

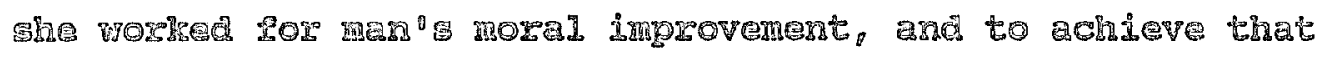
goal. Carzol a argued, "the intellect or woman mut then be cut 1 Wted

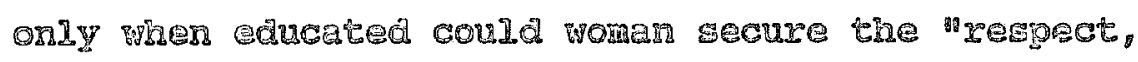

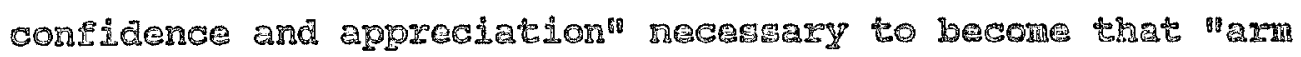
of ficrength to Bree Aneradea. 40

Ever when using analogies to compare the women of her day to the woren or Sperte, Athens, Rome, and the

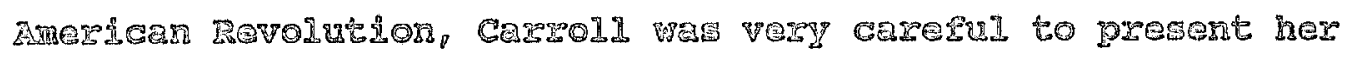

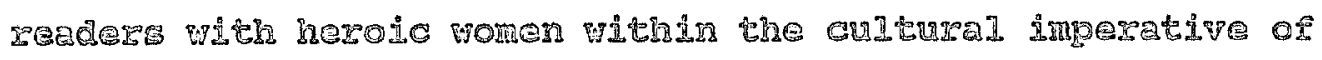


the republican mother and the cult of domesticity.

We want no Joans of Arc to make America vascular and alive [as religious as Jeanne d'Are may have been, she was Catholic, dressed in men's clothing, and led men to battle, none of which appealed to Carroll's view of what women should do, even in times of sational per. 11 . - we want falthiul and true women, who neither shrieg nor protest, but pray: women who neither mount nor sink: who are neither heroines nor fools: but Amejican wonen, who can stand in their own shoes...11

Of course, the most obvious presentation by carroll of the republican nother ideology was her use of the garden tea party device to present the history and platform of the American Party。 By usisy mother and son figures as her party spokespersons, she was able to convey the respect due women as mothers and participants in the nation"s life in terms os daymto-day existence, noble acts in emexgencies, and a멍 grantors of new life by their procreative abilities. The son provided a mey to express grattude as a mearise of woman ${ }^{3}$ worth within the cultural framerork as it existed and without the need LOr enfranchisement. "My mother, " [America] ma:d, "You made me a man! Tou targht me to love

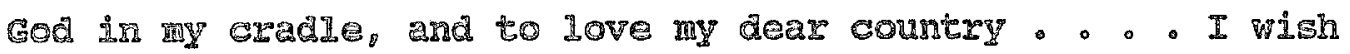
w1 the children had such a mother, then our dear country wonla have patriot sons." a11 belong to the Amexpoan party. 1042

ge the same time that cargold molehertedy enbracer the une of the imagery of the republican mother, she ocGas iorely used adjectives of political weight and 
force to describe her: "She was indeed the most original and commanding of women, an elemental force of great power, and Iikse a solvent of such range of affinity, as to combine and reconcile heterogeneous spirits into one society. ${ }^{43}$ But these stronger terms were seldom used, and carroll always returned to the Iess politicelly threatening mother image, reestablishing her subservience to the more political animal, man: ". - our Divine creator saw fit to aignify womax by the name of "Hother" when he gave ner to the companionship and comfort of man. It was in this sense [as (2) potential motiner] that whe became the Eve to the Amorican Eamig - . - ${ }^{44}$ Even wher dealing with the history of women's past patriotic deeds, for instance, noting that Washington had expressed his belief that, "with [woner"s] active natdonal symathy, we had nothing to fear" "Carroll Was caretul to attribute women"s success not to masculine incentives such ar dreans of achievenent and glory, but to oduty: and [ther] would have fallen short, had they done Iesc: 0 " womm ' place in politics, Cazpoll stated in no uncertain terms, "Let no cry of "woman's zights deter you. That charge has no significance hers.

The Great Mrerican Battle seems to nave been a fair

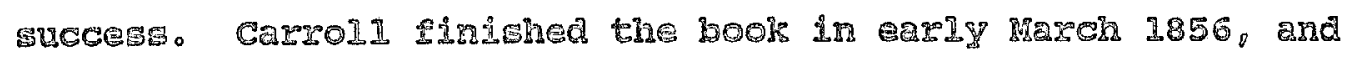
by hay mote to her father of the papers announcenent of the sele of "20,000 copies of the Battle and the whole 
country is alive in its praise--I wish you could see half that is said."46 she was startled, she wrote, to find that her publisher had "a women agent," but she appeared to be a good choice since she was "getting a large number of subscriber: . . " Har biggest concern vas the number of newspaper ajtor mo had not yet calnowledged receipt of the copies sent them. "This İ Elerce acting through the

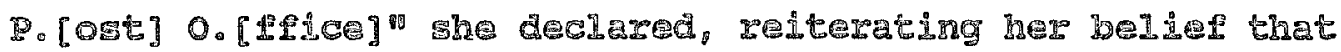
Pierce' Catholic Postmaster-General was taling advantage of his position to purge the mails of all ant

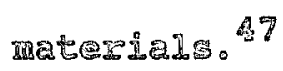

But compliments for carrol' ${ }^{\circ}$; work did make their

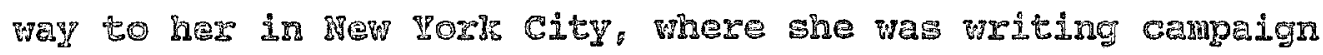

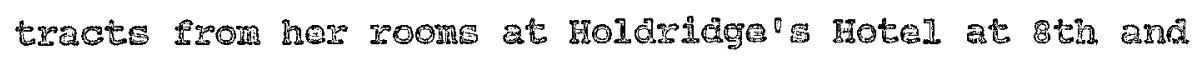

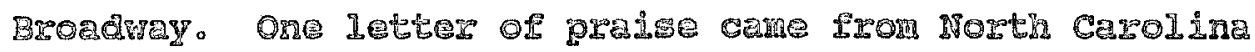
Anereㅁan Party leadar Remeth Rayner. He looked at the bools es an opporturity for the party to erplain the meep

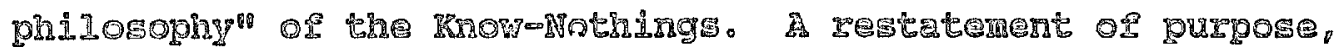
he noped, might turn the party way rrom its current state, in which It: principles had been "adulterated by the 5eIf [orogres. Rayser feared the widening split in the party over the shavery iฐgue moude overshadow the more important

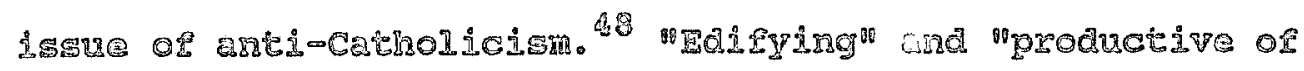

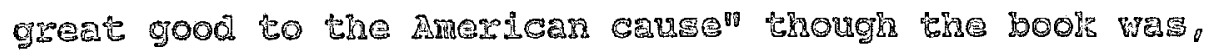

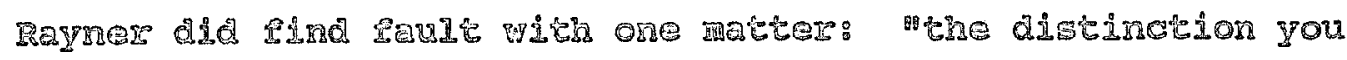


attempt to draw between native and foreign Roman Catholics.. . You are wrong . . . in the main, the native papists are as intolerable as the foreigners." Both groups, he believed, gave a spiritual supremacy to the pope that was able to release cathoilas "from the obligation of an oath-m the oath of allegiance to the constitution... We must malse war upon the whole system. 0.49

Cardidate Filmore, to whom Carroll had sent a copy o1 the book' read it, but aid "commend her zeal in the cause. ${ }^{850}$ His om zeal mas a bit more wuspect. Filimore ar a candidate did not give carrold mush to work with. Not a particularly charisnatic politician, he was decidedy Iukewam abont most of the tenets of the IRnomoNothing Party. He ras not ar ant-Catholle, nor was he a nativist. But he was aware of the growing populazity of the American Party and Iike nost retired presidents, he was interested in mploynent which wonld not demean the office he had once held. A raturn to the White House womd sut him just flne. The demise of the maigs had left him temporariy nomeles: pollticalin, since he viened the Repubilcan Party ag too sectional to guarantee the country"s stability. FiIImore had supported

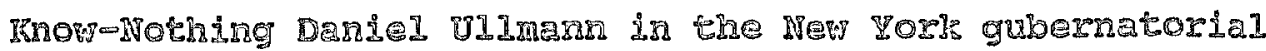
race of Ins and wrote or hir comeers over the "corrupting Influencer that the struggle por control over the foreign 
vote in the state had occasioned. Protesting that he had "no desire to mingle in political strife," Fillmore nevertheless had become a suorn know-Wothing and had accepted the nomination. 51 But even as the American Party sominee, Fidimore still apole not of anti-Catholicism or netivisim, but only of "freely acopt[ing] the principles of the Inow-ryothing party.

The religious issue, about which Fillmore refused to take a stand, was one which carrol1 had hoped to resolve for the Ameran Partw by drawing a clear aistinction between native-born and soreign catholics. It was the "gystem of popery" against wich she mrote, 53 "foxejgn, ungrateful refugee" who matntained allegiance to their native rath oven after neturalization. 54 as the callican Catholic: in Trance had stood for no papal interference in temporal mattars, so natrve-bors GatholdGs stood agadnst papa

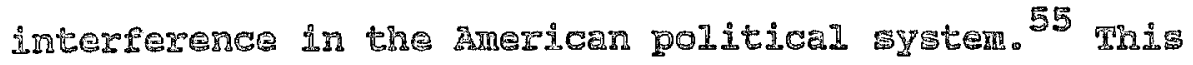
distincison was Greid for Carroll to make, not only politically, but personaly as well. Everyone inew the more prestigious branch or the praryland carrol1. were catholic. She conld "hosor that paternal ascestryg 56 but felt that "so baneru an ovid was papal control over votes that it sac become pardonale in all eyes, "58 presumably

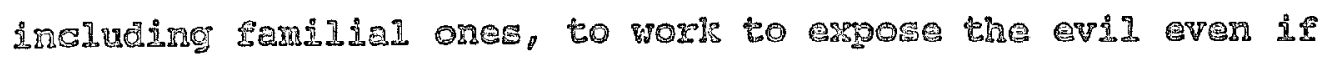
she, and the rmerican Party for mhich she wrote, appeared to some to be mingotg and blockheads. 
Politically the distinction was required so that those states with strong Know-Nothing parties and large Catholic populations would stay with the party instead of defecting to the Democrats or, far worse, to the newly-formed Republican party. Both Carroli's native Maxplend and the southern state of Louisiana, for instance, had substantial Catholic populations who were a part of the strongly nativist Rnow-Nothings. Louisiana in particular presented a problem. At the Amexican Nominating Convention In PhIladelphia in February 1856, the Louisiana delegation contained a nuber of Catholic members. The convention allowed their aredentials, but the feasibility of seating Catholic delegates in a sirongly anti-Gatholic convention depended upon this: distinetion between native and foreign-born Catholics carroll had laid out. 60 Carroll corld-inded, hat tomaceept the

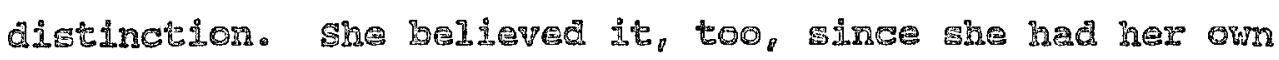

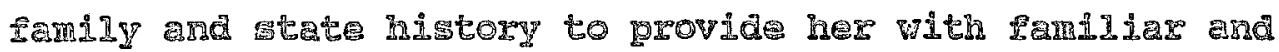
familiel eramg Hes of patriotic rativemorn catholics. Badjeal Knownotnings such as Irenneth Rayner, however, vere undex no such illugions as to the contradictory rature of allowing the Loulisane delegates in. "I can not tell you the deep mortification I feel at the compromise with

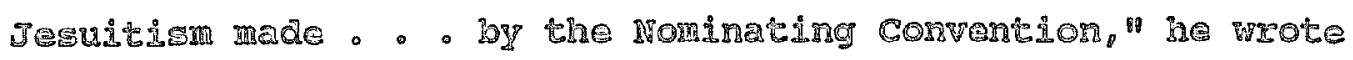

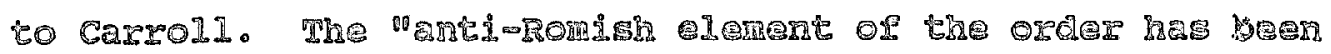

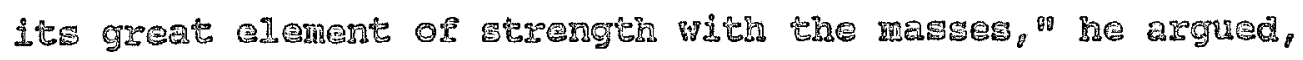


and admitting the delegates "I: fear. . - was a fatal step . - those bodies surrendered to the enemy the citadel of our strength." 61 The damage done to the fortunes of the Mmexican Party was primarily over this issue, according to Rayner, not over the sectional guestion of slavery, also present at the Philadelphia convention. wortherners had bolted from the convention, and the lnow-Nothinge were "1ijely to Iose all" over "our divisions and aiscords."62 But such uncompromising anti-Catholidism as Rayner's was too offensive to survive politically" If the Amirican Party righed to win the election, it had to tone down its anti-Catholicism enough not to lose votess to the othur parties. 63

The Great Anericar Battle had concantereted on the imperding talcover By the "Romish Hierarchy." In election pamphlets she wrote throughout the spring and sumer of 1856. Carroll shirted emphasis to concentrate on exposing corraption at the ballot bos by foreign woterg and on the necessity of preserving the union.64 phe sectoronal appeal of Republican nomine John c. Fremont had provided the Mmerican Party an opportunity to present Fillmore as a national candidate. unI ife Famont, FIIImore was not a candidete for those 19 mho desired an administration for the North as againgt the Sourh, or for the south against the

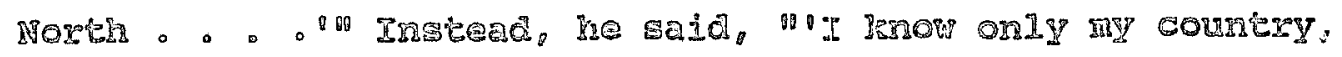
my mole country and nothing sut my country.o 65 
The preservation of the Union as a campaign issue was further discussed in Carroll's pamphlet, The Union of the states. While there was still mention of the dangers of a coxrupted democracy because of foreign voters, Carroll devoted most of the pemphlet to other issues. Fanaidil abolitionists had combined with Democrats to cause sectional stxife, and it had been only "the Roman fimmes: of Wr. Filliore, exhibited best when Filmore signed the Compromise of 1850 after President Zachary gay $10{ }^{\circ}$ s death, that hed saved the union. 66 The civil war that raged in Kansas, she argued, resulted irom the Democratic administration's incomptence, a situtation that could have been ayoided had Fillmoze been renominated and reeleated in 1852. Continued "agitation" in Ransas and contrinued Democratir Interference with the bellot box were in store if American did not return to Fillmoxe $1 n 18560^{67}$

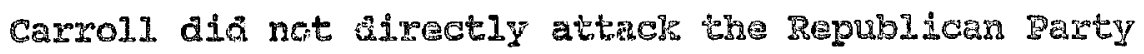
in this pamphlet, as she did the Democrats, but she did axgue that Filimore was a beter candidats because he had been nominated by a national rather than sectonal party. In so doing, whe conveniently jgnored the "Horthern

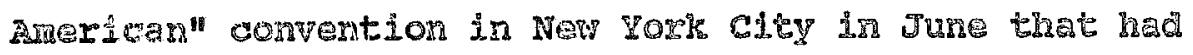
effectively âsea with the Rapuliwan by endorsing their

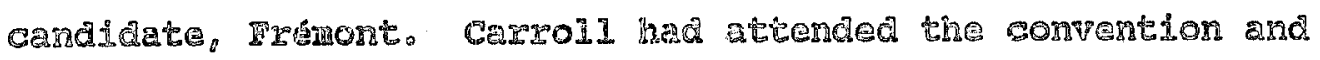
been aismyed at the intransigence of the dirsicant northemers. It was "treason to the onton" and "madness" to 
nominate a sectional candidate, and since she saw both Democrats and Republicans as sectional parties, she presented Fildmore as the only national choice. 68 Also issued prior to the election was carroll's Reviev of Pierce's Aanisistration. This was an exhaustive year-by-year Gritigue of four years of Democratic biunders under the administration of Frankin pierce. While the Review contaimed many of the same ideas as vere in the creat American Battle and Inion ol the States, it was particularly insormative regarding Carroll's ideas on foreigr policy. Her opinions were characteristlo of the antebellum

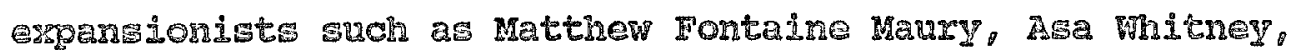
and WIIIA HEr seward. Wot limited to the continentalism

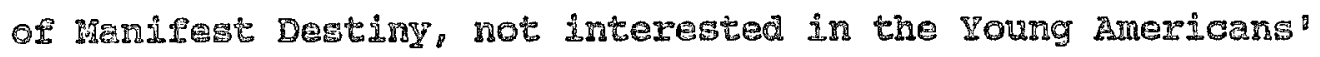

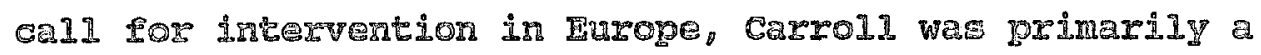
comercinl spansionist. She argued for a Poreign and donestic policy that would benefit trade, a consular and Aiplomatic service to promoto the empamsion of Anerican

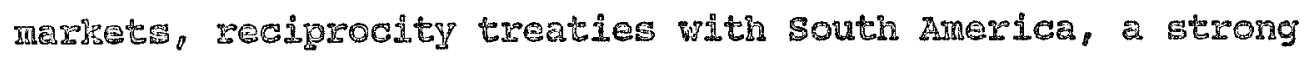
navy and a forceful Comandermin Chief to protect Americans abrod. ama peace with Furope to avoid the disyuptons at trade any war wowd bring. These were all points upon which

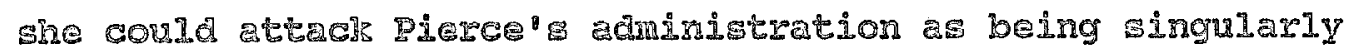
inersective.69

The Revien, Iire The Great Maejcan Satote, was a

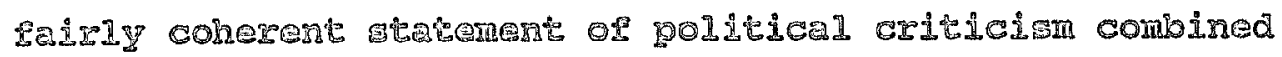


with a recommended course of action for its readers. Here again, Carroll took care to reassure her readers that she Jnew her Iinits "within the province of feminine delicacy." At the same time, she knew "of no rule to exclude females from society or the discussion of any subject which has an immediate bearing on the social, moral, and political desting" of the country. She pointed out, rather 5arcesteaIIy, that "an American female is not an idle statue of a pagoda, or of a Turpish seraglio . . 。 Reader: should have no fear that carto11, or any woman expresing a political interest within these particular provinges, wouhd "trespass either on the rights of the male

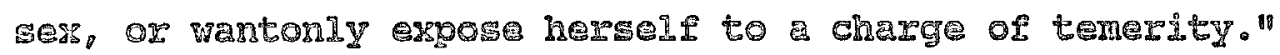
In a searoh for truth, all should be given an opportunity to participate wnce good of Indiviสnals, Of gociety, and of the natdon. In wuh an interdependent society, "the isterester and destiny or the nothers and daughters are in comor with those of

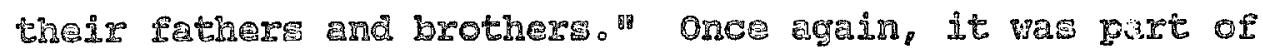
Moman's duty as a mother figure not to Mbe jgmorant on subjects wh mina," since momen were responsible for "the moulding of the rising generacion - . ${ }^{\text {p }}$ Cargol "g ow motivation for

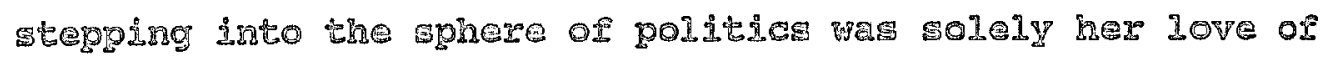
conntry and her ${ }^{82}$ desire to waren the reader to the vast importances of the subjects treated by her work. 70 
The summer of 1856 wore on, and Carroll wrote on. Fillmore had returned to the United States in late June and had greatly angered carroll by his failure to call on her, especially considering "all I did, nay permitted, in your behalf, for I have been the author of articles which were made effective by ignorance of cheir source.... 71 Pexhaps Filmore feared the effect of agmowledging hex worl printed moder her om name. "gor the tirst time in our instory woman has venturea openIy and without disguise to Espous the cauge of her country . . . But this was sonething not to fear but approve. It had "arraw the applause of your ser, and every distinguished member of the

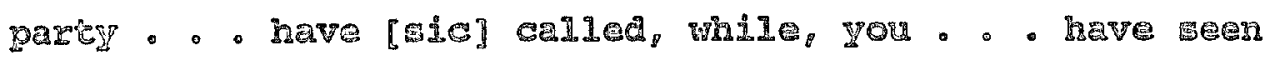
flt. . to show so much indifference... . Those

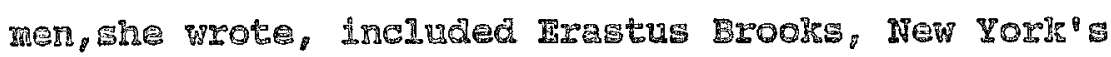
Rnon-19othing gubernatoxial candidete hoping tor a ride on FIIImore: Goettails, 2 . B. Baritett, the rational President

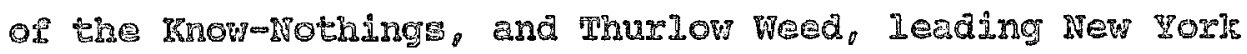
Reprbidican ard porer brokex. In addition to their calls, Carroll lsept up her correspondence with Thomes corwin of ohio, Zenseth Raynex, and Jomiah Dolk of Washington.72 By InIy, Filmore had apologized for ML seglect, withing Carroll from Buffalo mhere be spent the ตmmer.

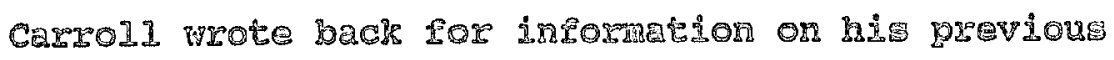
administration to use in the Review and other pamphlets. He

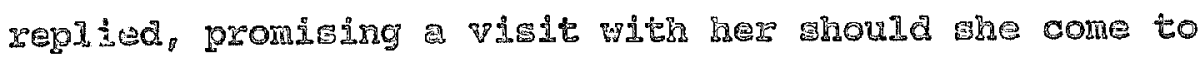


Niagara Falls. Her hard work on his behalf was not unappreciated as it was ". . gratifying to know that I have at least one friend on whom I can rely through good \& through evil ... . ${ }^{73}$ Along with her campaign tracts, Carroll was finishing her massive the star of the West; or, National Men and National Measures. Hew work10ad was beginning to take Its toll, both on her health and her work. By August she had to stop work for a while to recover her energy, but she soon picked up her pen to continue. By september, the star of the west was ready for the press. 74 Perhaps reflecting the strain of overworl, the Star of the west was the pooresc of Carroli's campaign worics, the most disgointed and incoherent. Apparmty It was a collection of axticles written and previously published. Gethered together for the book, the essays had Ifthe in common. She re-examined the Naval Board's reorganization work of 1855, Goncentreting particularly on the sad plight of Comodore chares stewart, the raning officer of the United states Nary. who had bern placed on the reserve Ifst and to whom the boor was dedicated, and on Iientenant

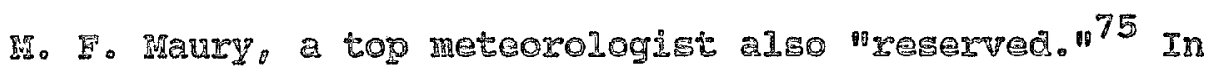

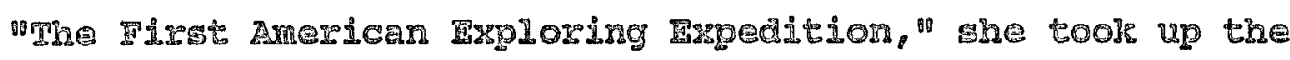
cause of Jeremiah Year LOR COngres: and then was Iefuged parmisaion to join the united states

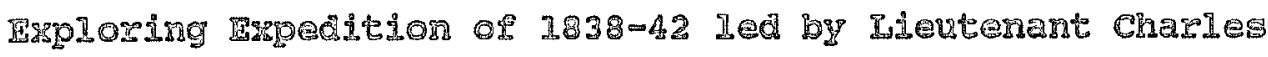


wilkes. ${ }^{76}$ she wrote a promotion of a transcontinental railroad whtch would benefit trade by giving Americans "a hold on the wealth of china. . and hex 700 Mililons of inhabitants. 77 The railroad would have other salutary effects. It would make the gold of callfornia more aCCessib 10: it woula save time, expense, and troule in trade and commerce. It wonld also prevent the weression of the Southwest from the untted states-ma worxdsome possiblitty because of the area"s ${ }^{7}$ solation. 78 Isolation In the region sad already led to abuses of democracy, to vaisorders . - the villaimous practice of stufing the ballot-box, the elevation of the scum of sorlety and

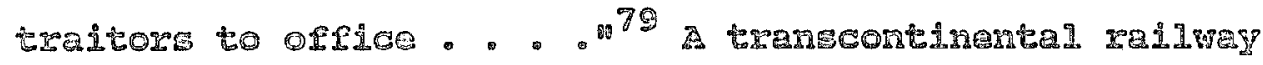
morld Ghage all that, ar weI a serving to mite the conntry and to advance Protestant eduGation and

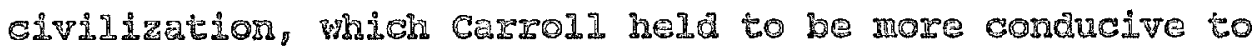
8conomid growth becarse Protectants had fewer solidays than Cachodics.90

Incoherent as The star of the west was fCarroll also

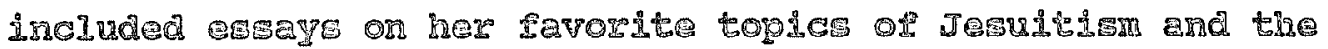
dangers of Jesult equgation, It din have one mifying

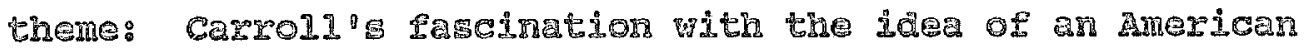

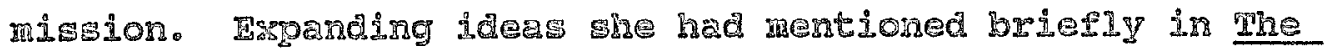
Creat American Battle, Garroll described the mission of

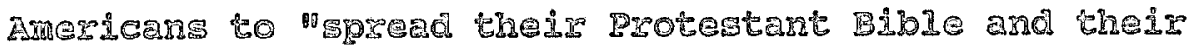

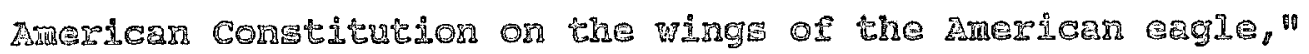


so Americans could throw their weight "in behalf of equality and justice over the countries of the world . . . ." Not incidentally, those actions would also mean that vour own strength shal1 increase, our own resources expand, and an additionel imperus be given our moral, comercial and political greatnes. "81. In The Star of the West. Carron

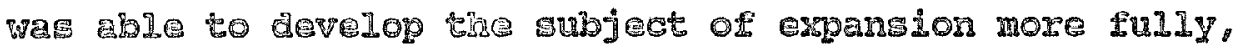

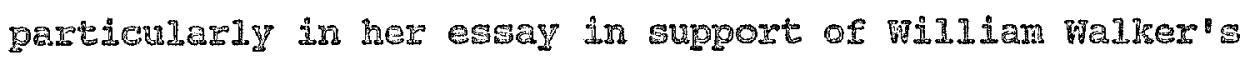
popular filibustering adventures in wicaragua.

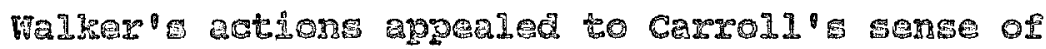
rajes $10 n$ and duty that wore 50 meh a part of her

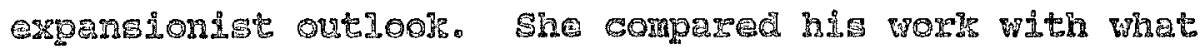

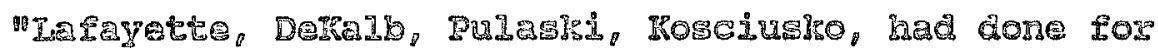
Anericen 1iberty - . - Mo, then can repress patriotic emotion or deep sympathy for his tramph: Hnerica was

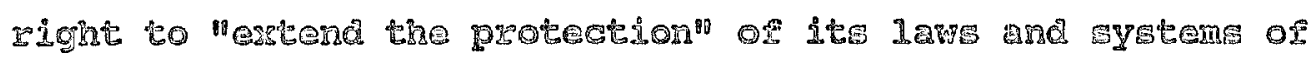
government to a people who had supposady MnV Inted the

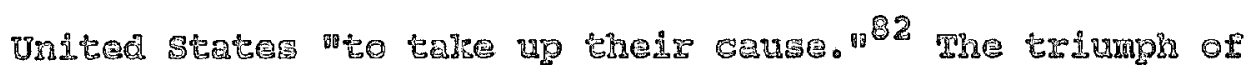

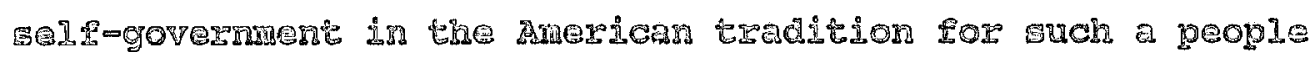

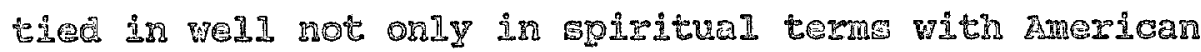
Lrterest in 1 inerty and justice, but in economic tems 25

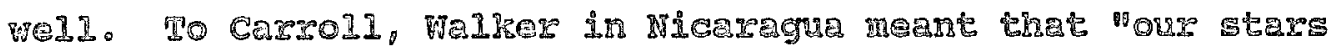
and stripes vill yet flome over the Pacifie gate of the

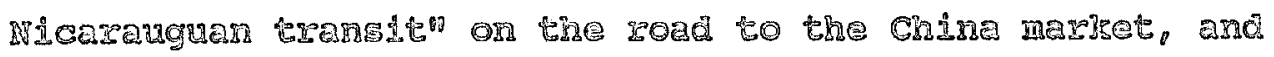

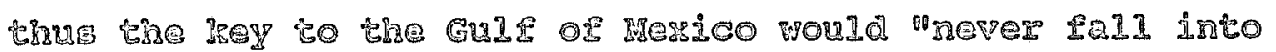
the hand: 0 3 
"essential to the commerce of the United states" must never be "owned by their enemies," or by the enemies of the United states. ${ }^{83}$ Walker's activities provided Carroll with the perfect example of what she viewed as the nobility of the Ameriaan mission in action in Central America, restoring order and peace through American systems of government, and, at the same time, ensuring the preservation and promotion of Unitea states trade. 84

Carrold must have been greatly pleased to receive Walker's note thanking her for the copy of the star of the West that she sent him after its publication in october 1856. It was, he wrote, "a source of consolation as well as of encouragement. - to recenve such assurances" as she had manifested " He promised to try to visit her before he returned to Hicasague to converse with her personaly "about some of the subjects you treat of in your volume" There is no indicetion that the tro ever met. Her descripton of his public ppeming presence, howevex "an expression of medraegs, accompanied by a nasal tone and sluggish utterance, which would arrest attention in any assembly"y, was peculiar enough to suggest an encounter of some kind betore his return to central america and subsecuent arecuston by the Hondurane is 1860.85

Bezhap becuuse or the essay on the popular exploits

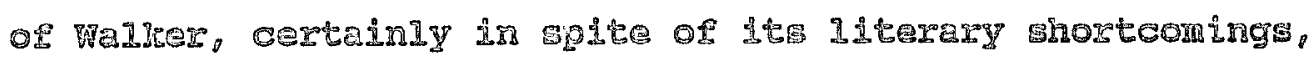




\section{The star of the West was Carrolil's most popular book,} runnirg to three editions. The first came out in october 1856, the second by December $11_{\text {, the third in } 1857.86}$ carroll had no time to rest on her laurels, however. The election was fast approaching and she cranked out two more short pawphlets. One was distributed in Boston, where she had gone to worg with her publisher on The Star of the west, the other in New yoxk, where, she wrote Fillmore, it had bers declared "he best effort now that can be made to save" that state for the Inoy-Nothing 87

Carrol attagked Demogratic mominee James Burbanan most vigorousiy in the fixst of the two pamphiets. Which? Filimore or Buchanan dragged forth the spectre of war with spain over cuba by reviving the issue of the ostend Manjifesto, 10r which Bucharan had been party regponsible, and which he was supposedy pledged to cary out if elected. The result would be "War immediately with England, France and Spain! ${ }^{88}$ More domestic concerns wext found in

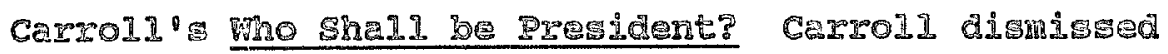
Repubilican Framont election as "mathematical. - impossibility" because of southern opposition. 89 that, she ray have at last zadizad that

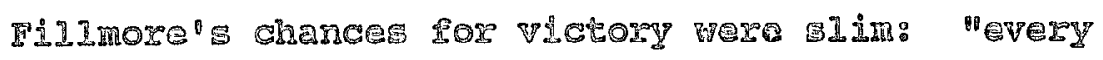
vote - . cast for Fremont, is a vote really given to Buchanar. " 90 Buchanas state: Fillmore would wend in troops to restore order. The 
disunion of America that was sure to result under Buchanan's administration would lead to a "general paralysis" and eventual destruci:ion of the country. ${ }^{91}$ carroll was becoming aware of the very real possibility of a Inow-Nothing loss if the party could not attract wore votes Eron othes partae: "Repulican, Denoczats and Whis, join the Amexicar army - . and aid ng in electing Fi11wore. - Do this non and sottle minor aifferences at a more convenient season." 92

Carrol1 alearly aid not comprehand that the Republicans would never wake the necessary compromise on the Blavery 15sue that was required to mibrace Fillmore's candiagy. For Repulican to support the American Party

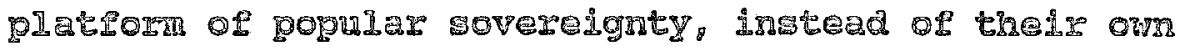
platform whioh opposed any extension or slavery was mor a "minor aisference." It

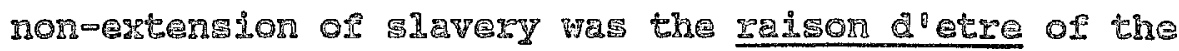

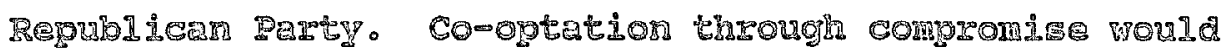
inอง Whe "more convenient season" mich Carroll hoped ror

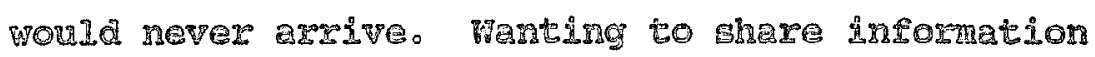

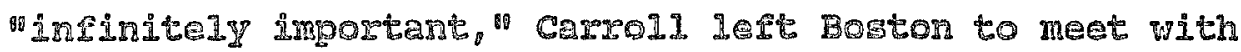
FIIInore one Iast time before the election.93 she vas

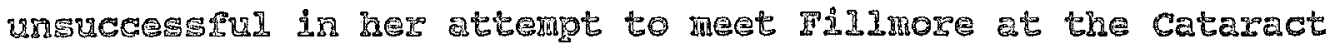

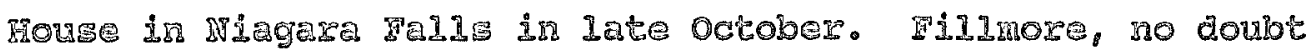
concerned with election matters, did not respond to 
Carroll's letters asking for an appointment. Carroll, disproportionately offended when put off, was convinced that "some malignant influence" was swaying Fillmore's mind against meeting with her, especially considering all she had done for him. or perhaps Filmore aid not "Iife a political woman, but my exiends say I have been more than a Jessie Frémont to the FilImore cause, "she wrote, referring to John C. Fremont's politically ambitious spouse. 94 Hurt at his silence, she took the trair to Bufealo to awalt his appearance. She added a postscript to a note requesting he call on her with whet might be considered a threat, and was certaindy less than gracious: "You better let me know what time It will suit you to call here. 95 phat right or the next day Fillmore must have called and soothed carroll's wounded feeling, for their correspondence vould continue after cargoll returned to New york city to await election day. 


\section{Notes}

${ }^{I}$ David H. Potter, The Impending Crisis (New York: Farper and Row, 1976), pp. 249-256.

2Joe1 Ho Silbey, The Partisan Tmperative: The Dynamic: of American POlitiss Before the CIVII War (New Tort: Oxford University press, 1985), pp. 127-165. See also Filliam E. Gienapp, "Nativism and the Creation of a Republican ifajority in the Horth before the civil War" Journal of Amexican History 72 (December 1985):529-559.

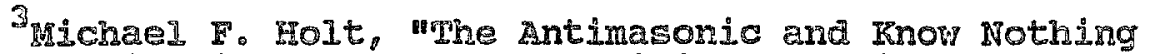
Parties, "in History of U.S. Political parties, ed, Arthur

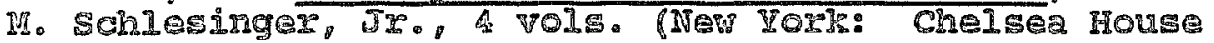
Rublishers, 1273), 1:594-595, 610-611: Fredexich J. Blue, The Frge-Soilers: Thira Party Politios, 1848-54 Uurbana, IIIinois: University of IIIinois Press, 1973/, p. 284 ;

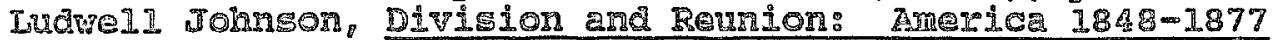
(NeE YOr?: John Wiley \& SOng, 1978\%, P. 21: David Brion Devi: "Some Ideological Functions of Prejudice in Ante-Bellum America, "Mmerican Quarterely 60 (sumer 1963):121: Jarry Jo Cazman and Bichard H. Iuthin, "Some Aspects of the Inow 150 thing Movement Reconididred, "South

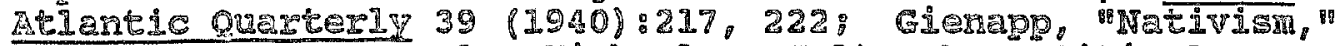
90. 530-535. See also Hichael Folt, The political Crisis of the 1850s (New Yorls: Jom wiley sons, 1978).

Halt In Schlesingex, $1: 569$ [Friedrien Anspach], The Sons of the Sires Philadelphia: Inpincot, Grambo :

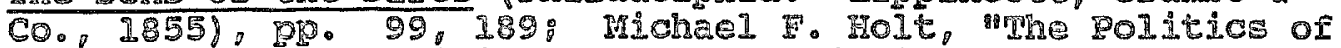
Impetience: The orjgins of IFnok Nothingis" "Journal of American History 60 (September 1973):323: Daniel Wa1ker How? The Political Culture of the American Whigs fChicago:

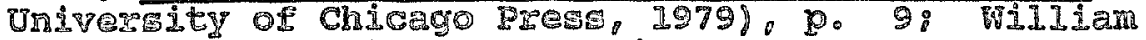
J. Evitts, A Aatter of Al1egiances: draryland from 1850 to 1861 (Balt 3 more: Johns Hopsing University Bras, 1974), פp. $59-67$.

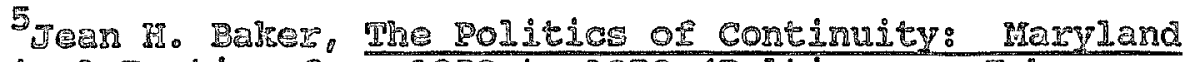

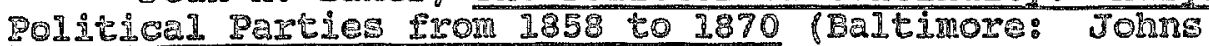

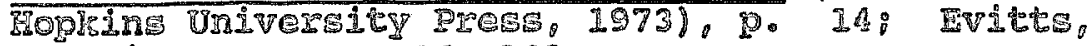
AlIeglances, 20.96, 102.

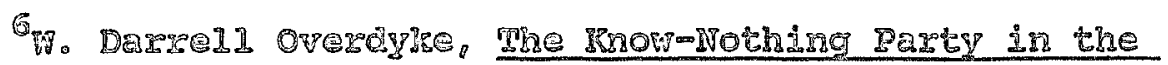


South (Baton Rouge, Louisiana: Louisiana State University Press, 1950), p. 12; Carman and Iuthin, "Aspects," pp. 216-217; Holt in Schlesinger, 1:596-597; W. Dean Burnham, Presidential Ballots $1836-1892$ (Baltimore: Johns Hopkins University Press, 1955/, p. 504; Anna Ella Carroll, Which? Fillmore or Buchanan! (Boston: James French \& $\mathrm{Co} ., 1856$ ). Most historians hold New York as the key state in the contest and argue clay lost because his status as a slaveholdex cost him whig votes that went to the abolitionist Iuberty Party. Lee Benson's study of New York state vothng patterns in The concept of Jachsomian Democracy: New York as a Test Case (Princeton, New Jersey: Princeton Univerisity Press, 1961 is cited by silbey as proof of the decline of the Ifberty Party in 1844 and the primacy of enthroreligious factors in the election. This argumert valialtes, at least in part, carrol1' s contention that clay lost the election because of the ethnic vote. See Silbey, Partisan Imperative, pr. $4-5$.

Ferry Aams held that the Know-Mothing Party was nost ateractive to "an old whig in Tennessee, or Yentucky, or Maryland, who had grown up to despise a Democrat as the meanest and most despicable of creatures: who had been taught an the gemi berbarous school of southern barbegues and stump harangues, gouging and pistol shooting, to hate and abinor the very word Democrat . . " See Herry Adams, The Great Secession winter and Other Essays, ad. George

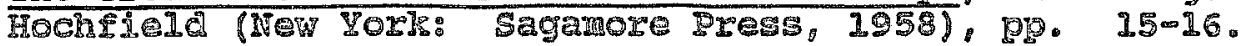

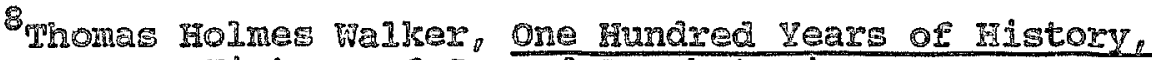
1802-1902: A History of Becona Presbyterian

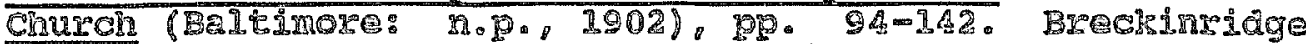

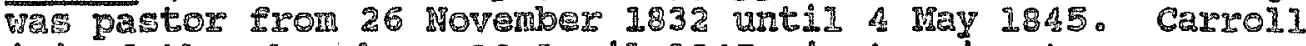
joined the church on 12 April 1845, just prior to

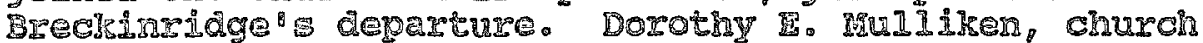

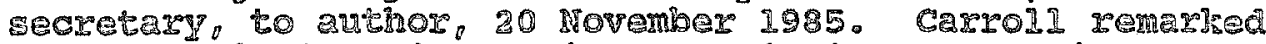
upon the distinct jmpres: discompres it was my fortune to hear from your

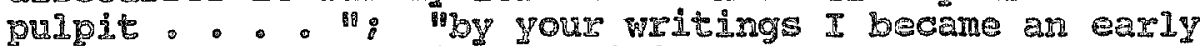
aisciple of yrself in opposition to Romen

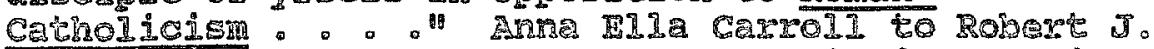
Brecrinidage, 29 Movember 1864, Brecrinridge Family Papers, Iibrary of Congress, washington, DC. See also Carieton Beats, Brass-Inuclele Crusade: The Great Inov-Mothing

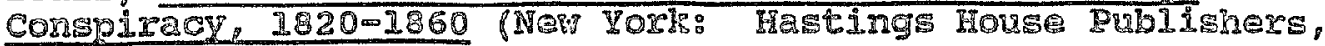
$19601, \mathrm{Bo} 172$.

9S1102y, Partisan Imperative, pp. 71-75: John Hope

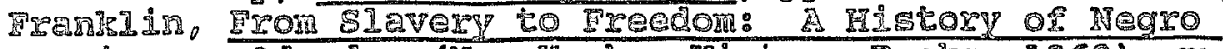

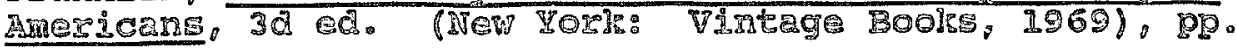


77-78; Evitts, Allegiances, pP. 2-3; w. Wayre Smith, "Politics and Democracy in Maryland $1800-1854$, in Maryland: A History, 1632-1974, ed. Richard William Ifoyd Fox (Baltimore: Maryland Historical society, $1974)$, p. 305; Howe, Political culeure, p. 164.

10 Anne FIla carrol1, The Great Imerican Battle; or the contest Between Christianity and Political Fomanism (New Tork: Oxton \& HIligar, 1856), p. 6. (nereafter cited as (GAB).

11 Rickard Hofstadter, The Paranoja style in Inerican Politics and Other Essays New York: Alfed A. Knop: 1966), $29.29-40$.

12 Carro11, GAB, p. 22 .

I3 Ibid。, I8.

14 Ibia., P. 20 .

I5Ibia. 2. 22. See also Daniel Walker Howe. "Victorian Culture in america, in Victorian america.

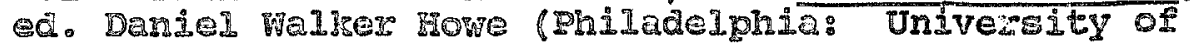
Perngylvaria Press, 2976 ), Po. 9, 21-26.

16 Carro1, GAB, 26.

17 TbLd。 PP. 3A, 3L.

I8 Ibia.g. 56.

19 Ibid. D. 56.

20Ibia., 8 . 6I.

21 Beals, Brassengnucisle crusade, po 178 : witts; Alegiances, pro. 71-73: Lewrence Fo Schmekrebier, Iistory

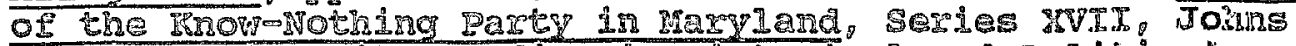

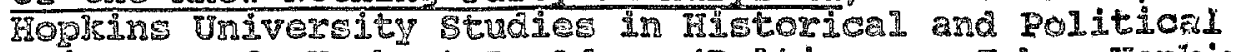
science, ed. Rerbert B. Adame (BaItimore: Johrs Fonkins university Press, 1899\%, pe. 15 - 16: Jam H. Baker, Anbivalent Americans: The Know-nothino Barty in Mary land (Baltimore: Johne Hoplsine Univeralty Praas, 1977), 9. 28.

22 Carroll, GAB? 72 .

23 Ibid. p. 28. 
${ }^{24}$ Ibid. p. 32 .

25 Ibid. , p. 115.

${ }^{26}$ Ibid., p. 120.

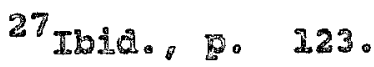

29 Ibid. p. 109. Carroll was particulariy offended by the appointment of catnolic James Campill as

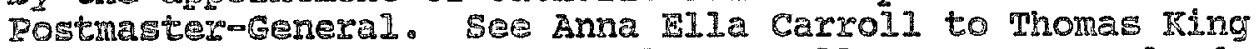
Carro11, 26 May 1856, Anna Flle Carroll parer, Maryland Historical society, Baltimore, Maryland; Allar lievins, Ordeal of the Union: A Honse Dividing 2852-1857 (New York: Charles SGribser's Sons, 1947, pp. 47, 324, 403.

29 Carrol1, GAB, po 104 [Mothere]. 30,182d., 178.

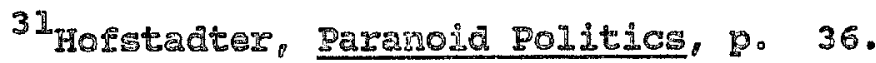

32 Carrol1, GAB, PO. 274-89: Clasies Oscar Raulin,

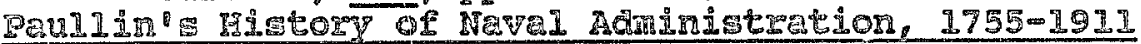
(Anmapoldg, Mary land: Uf. 5 . Maval Institute, 1968) po. 238-243. See also Charles stewart to Anne glia Carrol1, 18 Agril and 11 IREY 1857, Carrold Fagers.

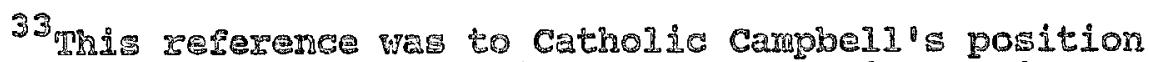

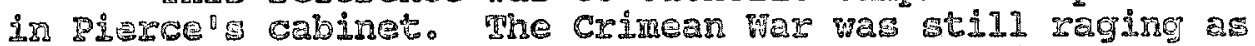
CarrolI mrote, but the peace contaxerge in parts had begun by the tine GAB was prolished. SEe also Carzold, GAB. PP. $277-278,127 \%$

${ }^{34}$ Carrol1, GAB, p. 3A1.

35 Ibid. p. 叉。

36 Carrol E. GB, p. vo

37 Ibid., gू. 13-14。

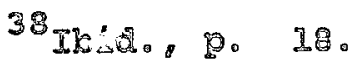

39 Ibid。 9.16.

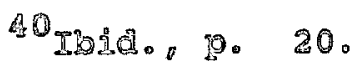

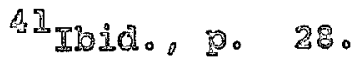




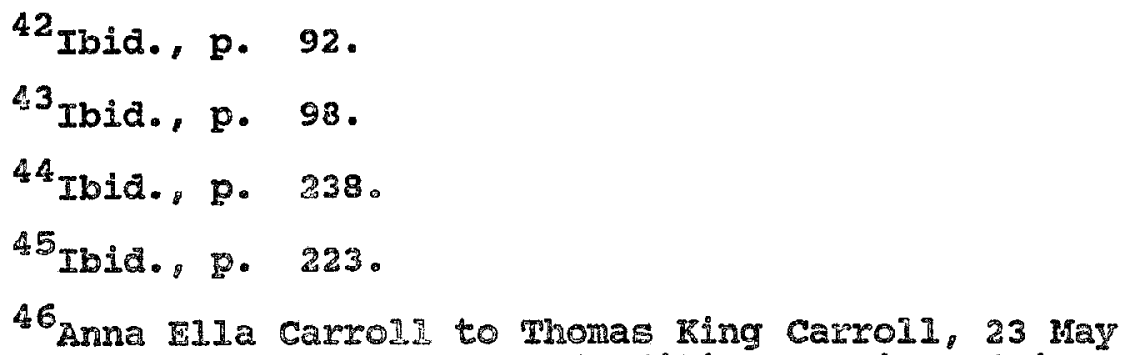

1856, Carroll Papers. A second edition was issued in I859: see walter P. Armstrong, "The story of Anna Flia carroll: Politician, Lawyer and Secret Agent, "American Bar Association Joumal 35 (Mareh 1949):199, $\mathrm{n} .2$.

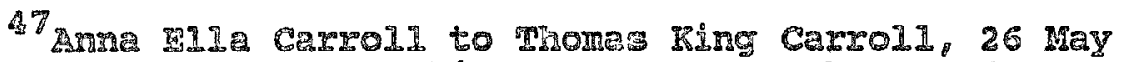
1256, carrol1 Papers. This was a comors charge of

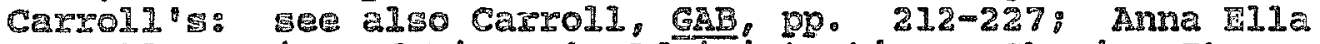
Camoli, Review of Pierce"s Adrinistration: Showing Its Orly Popular Measures to Have Originased with the Executive

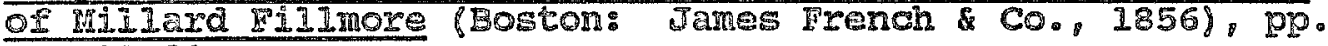
$24,28-29$.

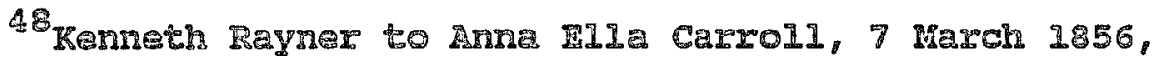
Carro11 Papers:

4 Genneth Rayner to Ansa FIIa Carrol1, 12 May 1856. Carro11 Dapers.

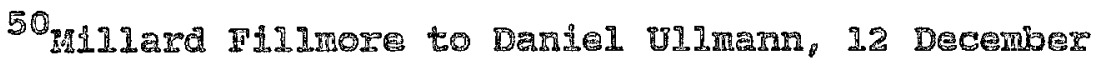
I856, Fil1more Rapar:

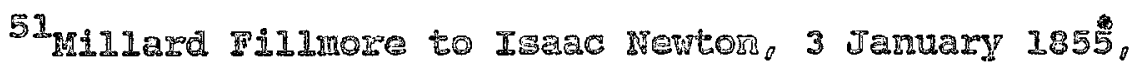
Iำ Hillard FiImore gepers, ed. Frank 18. Severance, 2

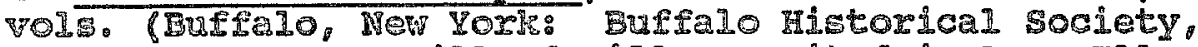

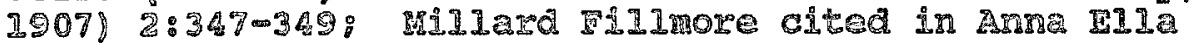
Carro 11. Fhe Union of the States (Boston: James French \&

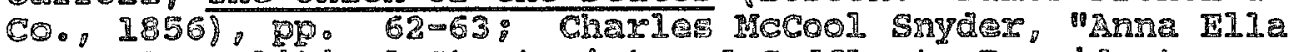

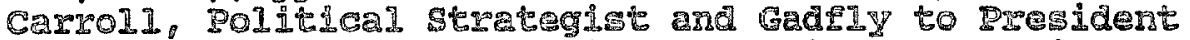
FIIInore, Maryland Fistorical Magarine 68 (Spring 1973):44.

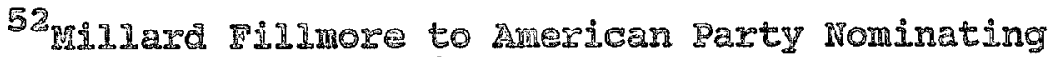
Committer, 21 Mey 2856, in Papers, 2:358-359.

$$
\begin{aligned}
& 53 \text { carzo 11, GR, } 9.4 . \\
& \text { 5s Tbid。, pp. 154, } 156 \text {. }
\end{aligned}
$$

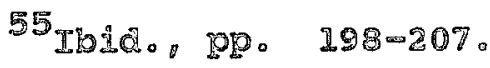

$$
\begin{aligned}
& 56 \text { IbIํ. }
\end{aligned}
$$




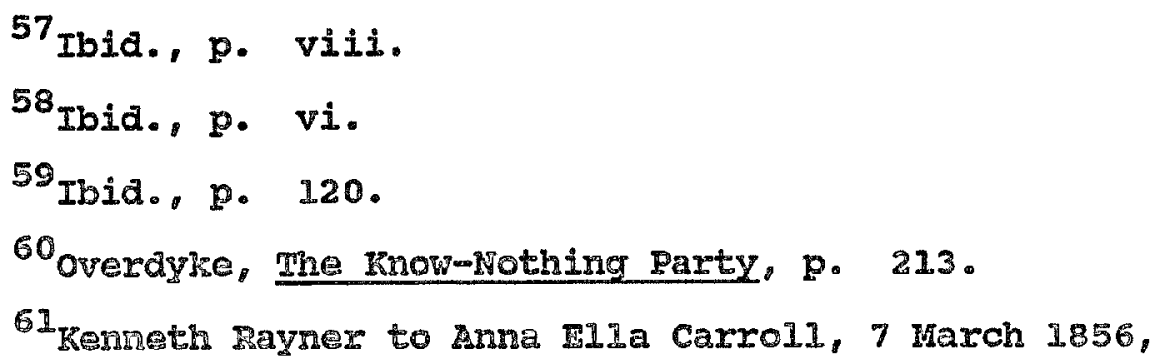
Carrol 1 Papers.

62 Renneti Rayner to Anna Ella Carrol1" 12 May 1856 , Garroll papers.

63 In 1 ine mannex, Republicans incorporated anti-cetholis xhetoric in its campaign to attract Inow-Nothings to its party, hoping to capture voters who were both arti-catholis ard anti-siavery-extension, sinese the Inow-Hothings had not tajer as clear a stand in the 5lavery issue. See Gienapp, "Nativism, pp. 542-545.

${ }^{64}$ Barex, Ambivalent Americans, p. 47 . Carroll ${ }^{\circ} \mathrm{s}$ Union and Reviev are considerably less anti-catholic than GAB, as are her two other pamphlets of 1856 , Which? FiIInore or Buchanar! and Who ShaIl Be President? An AppeaI to the Peuple (Boston: Iames French and Co., 1856). A thira pamphiet was a reprint of chapter 25 of GA: Mmerican Nominations Fillmore and Donelson, Being an Eztract from a Work trititled The Great American Battle: or, phe contest Betreen Christianity and Political Romanism (New Yords: Miller, Orton \& MIIIgan, 1856!.

65 Overaype, The Thow-Mothing Party, p. IA2: Carman and Luthin, "igome Aspects " p. 218 .

${ }^{66}$ Carro11, UMIOS, PP. 26, 54, 12.

67 IbIอ. P. 28.

68 Ibid. P. 49. Ama Ela Carroll to Thomas King Carrol1, Carrol1 Daper: Sry ; 45.

69 Charles Vevier, "American Continentanism An Idea ô Frpansior, $1845-1910$,

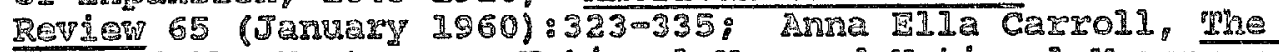
star of the gest: Or, National Men and Mational Measures,

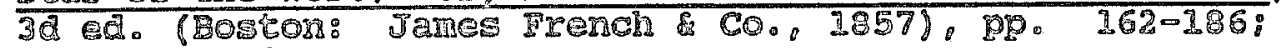
Carsol1, which? Pp. I3-16, 34-35. 
${ }^{70}$ Carroll, Review, pp. 1ii-iv.

${ }^{71}$ Anna Ella Carroll to Millard Fillmore, 26 June 1856, Fillmore Papers; Snyder, "Anna Ella Carroll," pp. $46-47$.

72 Anna 511 a carroll to Millard Fillmore. 26 Iune 1856. Fillmore Eapers: Amm Elia Carroll to Millard Fi11more, 6 November 1856, Fillmore Papers: Anna IIIa Carrol1 to Thur10w Weed, 17 Foril and 11 December 1856. Thur 10 Weed Papers, Rus Rhees IIbrary University of Rocherter, Rochester, New Yorl: Kenneth Raynex to Anna ris Ia Carrol1, 14 November 1856 , Carrol1 Papers: J[Osiah] F. Polk to Ama HIa Carrol1, 25 Apri1 1856, Carrold Papers.

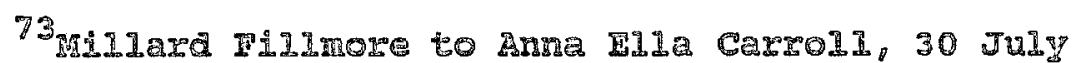
1856 , Cara 11 Papera.

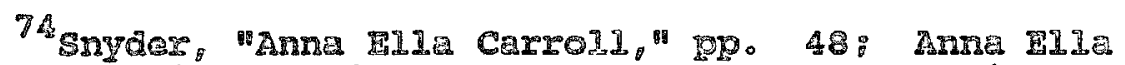
Carroll to Millard Papers.

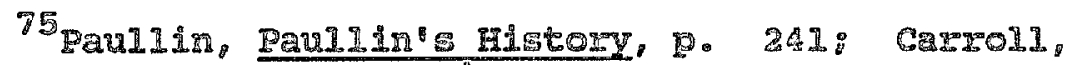
Stax, pD. $232-277,19.71$.

76 Camrol1, star, p. 122: see also Donald Dale Jaclson, "Around the world with wilres and his

'Scientides," Smithsonian 16 (November 1985):46063.

77 Casto11, Stas, p. 177.

78 Iอปล. D. $248-149$.

79 Ibid. P. 148 .

80101a, PP. $271-176$.

31 Carro11, GAB, P. 28; Carrol1, SEar, PQ. 346-347.

82 Carroli, Star, pp. 379, 384.

83. IBId. . 385.

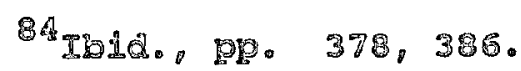

85

Peper: Carrold, Star, P. 349.

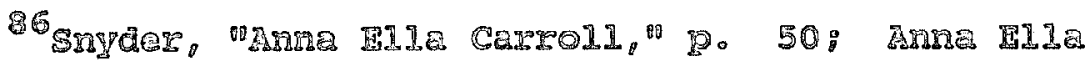
carrol1 to Thurlon weed, II Decembre 1856, weed Papers. 
${ }^{87}$ Snyder, "Anna Ella Carroll," pp. 50-52; Anna Ella Carrol1 to Millard Fillmore, 28 October and 31 October 1856, Fillmore Papers. In her 28 october letter, Carroll enclosed a clipping of a pro-Fillmore article, presumably hers, signed "A Voice From Plymouth Rack."

${ }^{88}$ carro11, Which?, P. 17.

39carrol1, Who...p. 3. This was the only time she mentioned Fremont by name.

20 Carrol1, Who.... D. 4.

91 Ibia., 8.

92 Ibia.

93 Ansa Elda Caxol to Hillard Filimore, 31 October 1856, Fidlmore Papers.

94 Ana E1la Carroll to Millara Fillmore, I November 1856, 31 October 1856, Filimore Papers.

95 Arna E11a carroll to H11ard Fi1more, 1 November 1856. Finlmore Paper. 
Chapter 3

Logesses

Fillmore lost. James Buchanar and the Democrats won: Iokn Chardes Fremont and the new Republican party were second. Returng care in slowly enough to New York City that Carroll hoped that the election world be throm into the House of Representcatives. On november 5 , she met with "Ieading Repriolicang" to suggest a fusion between INow-Brothings and Republicans, with Filimore as the candidate of choice should the House vote be needed. Fillwore, she argued, was the onig "rational" candidate and had successtully avoided the Issue of slavery. ${ }^{1}$ That issue, accoraing to caxroll was the "false" one of the campaign, but because the Republicans had dealt with it and thus split the national vote, they had "left the Dww to sweep the stakes. If othere had fought on the same principle I aid, the victory would have been corplete." she bIared her ser for bolding her bag: prad I beers a man I 
would have had this." More limportant, though, was the lack of funds for the campaign: ". . even as a woman, had I 20 thousand dollars to have worked with, to this end," victory mould have resulted.

At the least, carpoli was pleased that Maryland had maintained Its loyalty to Fillmore. She tools credit for the win. After al1, her worles had "most airculated" there, and "my opinions been most freely consulted" The problem had been Nek York state. "For weeks I beldeved It safe, and sure to bring vietory to Fillmore. Her beliefs, in spite of reports to the contrary, marked the difference between the "cold selfish calculations" of professional politicians and herself: mMy heart enter into my acts and I loving the cause, belleve in its triungh, "uren when political factors suggested the opposte. 2

Carroll received a warm Ietter of condolence from renneth Raynex on Noverber 18 which praised her for her "pure and aiminterested devotlon to thowe immortal principles of liberty in the late election. ${ }^{3}$ she grev Impatient to hem similar wentiments from the defeated candidate. She wrote him a Ietter or condolence and

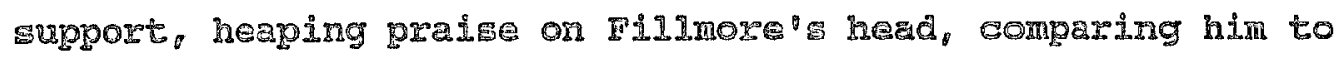
ceorge washington, sure he world "be admired by yr. whole country at a future day" In spite or ner earlier claim whet the slevery isøue was not of paramount importance to the Garpaign, Gre predicted that inis reant posibion 
regarding slavery would be the path chosen by all "sensible people North \& West. And the soi disant [so-called]

Republicans and our party must fuse" on that position to win in 1860. As much as Carroll admired Fillmore and his alleged, and unappreciated, political acumen, however, he must learn to be kinder to those who worked for the cause. "My complaint is that you can't see me as I do you--I am great in my womanly sphere." She closed her letter with a reguest for a letter of reference for a bool tour she was about to embark upon. "I intend to disseminate my 3 works wherever I go and mean to be power yet in this land, which It will be well to propitiate. "Showing signs of her obsession for power and recognition which would eventually dominate her Iife, carroll got what she wanted this time. Fillmore apparenty sent the letter despite her threatening tone, and thum inequertenty opened the door on the shady side of Carrold'g Iife.

Cargo11 tools Fi11nore ${ }^{\circ}$ Letter, along with ne from Rayner and one from Thoman H. Clay, II. of Kentudry, and presented them to the prems as support for a testimonial dirner to be given to show the American Parhy gapreciation Lor her work in the late election. This practice was common in the nineteenth centngy, but was usualy done for, rather than by, the recipient. 5 caroll was still in New York

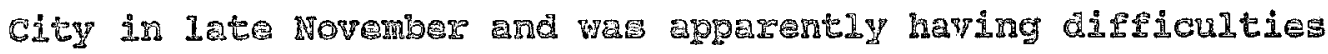

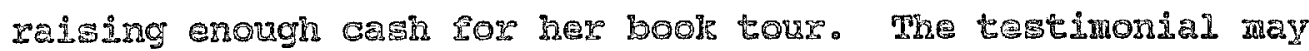


have been her idea, or that of William scudder Tisdale, a writer for Dewitt Publishers, a New York publishing company that carried a number of Inow-Nothing publications." Filmore apparenty discovered the unauthorized use of his letter and wrote to Daniel UI Imann in New York for advice. UI Imann had mun unsuccessful1y for New York governor as a Imow Nothing in 1854 and was now practicing law on Wall street.

UIImann's reply of November 25 was less than flattering regarding carrol1: clearly fillmore had not mentioned that he knew carroll fairly weld. "She is a regriar Jereny Diddler in petticoat, "vlman wrote, "and ซas once, sone jght or ten wonths ago, arrested for swindIing." ${ }^{7}$ Apparenty Carroli had emoroidered upor har Eamiy Iineage to Filmore, Iinking herself with Maxander Hamilton, but it was "the first time" UIImann had heard of the 3lleged familial relationship. UIlmann was not Lapressed by cerpol1 ${ }^{\circ}$ " ${ }^{\circ}$ political proclivities. I apprehend they hang very loosely upon her, and I suspect are adopted for each occason.

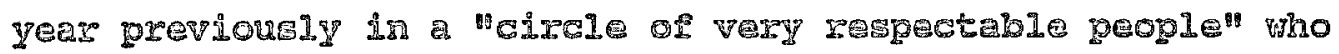
had become "verg inch alamed wern they I Iarmed her real character." In fact, carroll hac "trred her game on two or thres of my friends and upon me, but we were too old

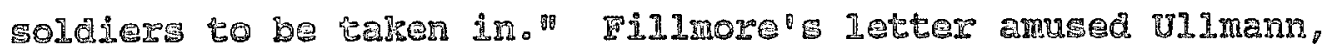

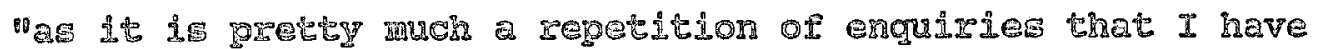


had addressed to me several times." 8

Fillmore was not anused. Unaware of his

perturbation, Carroll wrote on December 5, telling him she had fixed his letter "to suit" her purposes for the dinner. wwo days later, the notice for the dinner, with the altered letters printed below, appeared in the New York Dispatch. ${ }^{10}$ on the $8 t h$, Fillmore heard from Tisdale, demanding morey for the ainner. "The design in to rake it a gationel affain?" he wrote pompously.

When we Ienember that a lady or Louisiana was presentad with a met of magrificent jerelry for merely gtepping on board a steamboat on the onjo River, as a representative of the Southern States, it is certainIy right and proper that one who has performed ton thousand times : - more than this mere physicel act, should be the resipient of a testimonial ten thousand tines moze valuable than the ore presented to the lady uho stepped on boerd the steamboat.

Tisclale alosed his missive with a list of the members of the Breantentor Comittee, mich included Clay, Rayner, Thomas

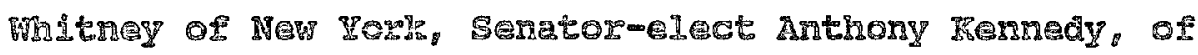
Maryland and Jacob Broom of BenmsyIvanja. 1

Not only angry, buz non suspicious, Filmore wrote again to UIJnan, asping bis opinion as to the dimex"s Iegitimagy. "I shall most cheerfully contribute my mite," he mphagined, but only if "the money goes into safe Raมฝ.

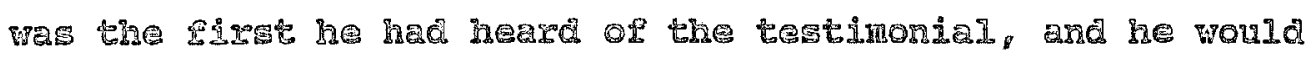
be glad to investigate. The Hew Yorg DLSpateh had made it seem as if Filmore hae "a high agprectation or the lady and 
the value of her services. I never did have a high opinion of either." Tisdale, he thought, was "a little hack writer" in publisher Dewitt's employ. In Ullmann's opinion, he belonged "to that numerous class whose pretensions are vastly in excess of their performance." He knew of no real scandal involving risdale, "yet I have conceived a rather unfavorable opinion of him." In fact, Tisdale had eariler "beguiled" UImann Into writing a favorable account of his abilities that "was made nga of vory improperly . . . " As for the weighty individuals on the Fresentation committe, no doubt, Ul Imann suggested, they had approached in the same Way as rillmore. 13

Carrol1" grimar motivation for using Fillmore and the idea of the testimonial ainner was doubless finaneial. Had the Inovmirothings won the election, her bools would have SO1d well. As It was, she wrote Thux low weed fhom she presumed she juew weII enough to have sent a flirtatious domand that he call upon [ar) to borson a humia dollars so sine could "bry wy 500 Volg Star of the West" [sic] which she could ther resell for $\$ 1.25$ each. ${ }^{14}$ she had to survive on hex witing as best she could. Mo patronage positions would fall to ner after the defeat of the Inow-Nothings. But while Filmore was widing to commend her for het worls for hin, he had "only glanced at her publications, neper - . read one through " and mes atogether unhapgy that cargold had talsen advantage of her contact with 
him. 15

A letter on December 15 to Fillmore from Jacob Broom in washington discussed party matters and made no mention of the dinner or the committee of which he was supposedily a member. ${ }^{26}$ A second letter arrived from Tisdale, demanding an immediate reply, and a note came from vilmann reporting that, while he could not "1earn anything very definite" about the affair, he distrusted the whole, as did those to whom he had spoken. "Wy own opinion is that they wish to obtair your name on which to base their operations. "17 The same mail also brought a letter from Carroll, apparently in reply to a demand from Fillmore that she return all of his letters to her. "This is the first time in my history.

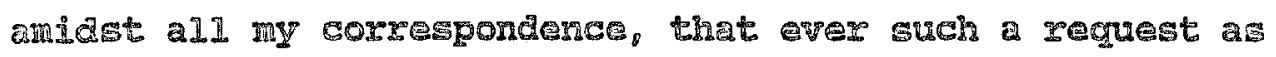
yrg was made." she vas too busy to accede to his request, she said. She was hara at work, preparing a new book of reminjscences of great Know wothings and other politicians. to be called men as they Seem and as they Are." Besides. she nad burned alI but two or three of his letters. Anyway, she could not see why he was so angry. arhe part published has chone you moxe good than that of any letter, you ever wrote in your whole life before, "she mote indignanty. Carroll blamed Fillmore for many of her financial

difficulties. "I nawe abalned you so entirely in my Books that, their sale in utrery destroyea in certain sections." Even though whe hed besn "repeatedy invited" to publsh new 
editions minus Fillmore's name, she refused "to emasculate and alter my Books . . . I will not depart from my principles to put money in my purse. If Fillmore wanted to complain about the alteration of his letter, he was free to do so privately or publicly. "That man is yet to be born in this world whom I fear or am not ready to meet through the Press or elsewhere. 18

It took Fillnere nearly ter deys to recover enough of his sang froid to reply to this remarkable defensive missile. Not oven a flattering letter from one Samul St. John consoling him on his recent loss could help--for St. John referred to his "excellent friend, Miss Carro11."19 carroll hersels aded fuel to the fire as whe ธent FiImore a copy ar the second edtion of me star of Ghe west and asked him to pass it along to the editor of the Buffalo Commercial Aavertiser so the paper could reviev it. Tohn B. Floyd of Virgania and others had been to see her, She wrote. "... Would you believe I comla have defended the charge of your cold pergonelie [personality]p seming unawere 0 Fismore's anger, she ingrired, "Don't you mean to answer my last letter? 20

$$
\text { Filmore sinaI1y ansmered, coldiy and efficientIy. }
$$
on the $2 y$ th. He na gart har boom on to the editor: as for

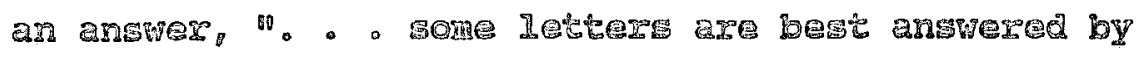

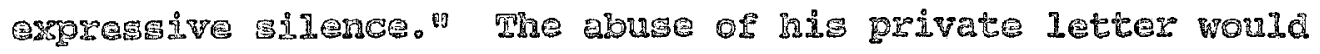
tean nin cambion in the Euture. Wearening somewhat-arter 
a11, Carroll was a charming woman, and in spite of Ullmann's accusations, she had done a good job for him and his party-he "would fain belisve the act was not yours," but that of her "evil genius," Tisdale. 21

carroll seized upon the way out graciously provided by Filimore, but not without a few parting shots. "Of all the trying things in my life, and you lnow of some, your

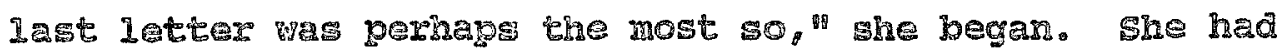
"פacriflead \& glaved" Ror him, had given him time and "my hard earnings beside... . with no notice or marping of confidentiality. Besides. "Heaven knows it was not strong enough, or warm enough, to attract any particular notice... "l she had beer his friend and had worted for him and the party and both owed her thashas and recognition in spite of the fact she had neither asked for nor been given "a single ferthing for her Worls. AS for Tisdale, wall, she had Iittle control over his activithes. Me Rab ben himea to do her proolreading and correcpondence, and whe maw him "yery seldom. 22

Tining of the matter, yes determinea to malntain his

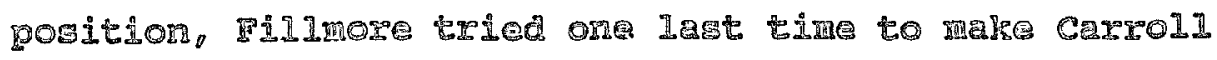

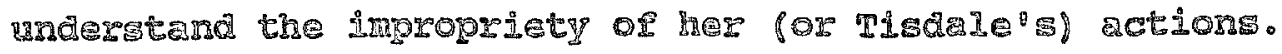

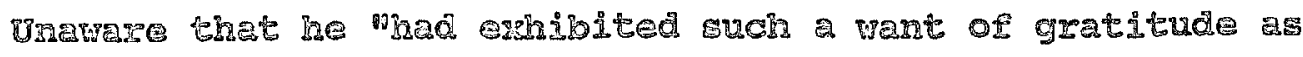

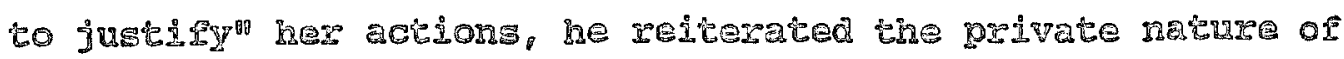
the lettar of recommandan ane expressed his sorgor at her

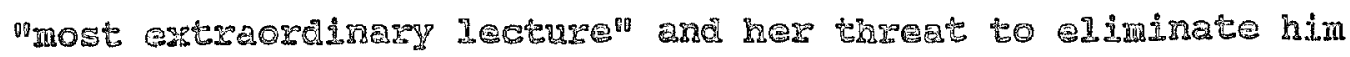


from her works. "But you will pardon me for saying that such threats have no terrors for me." If her friends gave her a dinner, he would make a contribution, but that was a11. "Standing as I do, I can not... single out one fxiend from all the rest for public honors. Your own good sense must convince you of this . . ." He would blame it all on Tisdale rather than carroll, "determined to believe" that her "upright and generous heart" was incapable of such an act. 23

Agein Fillmore had provided Carroll with a graceful way out: a belief that her feminine nature would automatically preclude such trickery. Again, carroll took it: but again, not without a few acerbic remarks about his part in the affair. If he had just told her, she would have maintainea his confidence, ". . that I might not havo been the imocent cause of inflicting a pain . . greater than that of your defeat." she would earn her laurel from pulite approbation of her worles in the future, though Fillmore's aistaste for singling out any one rriend for notice did seem to her rather curious. "had there been other ladies-or any one lady in the land, who had also occupied a porition" similar to hers, whe could have unàergtood his reluctance. But there were not. And she could scarcely believe his male friend: would be so "devoid of their vaunted chivalyy as to any a poon little woman" who had recsived special notice from his pen. As for 
Tisdale, he had taken advantage of the situation, and she had taken care of him: "I found out the man--And I have freely expressed my opinion to his own Mother, who is a true woman--Ie will do no more for me." She remained "your tried \& trusting friend, and I have to live and die with an unchanged feeling for you. 124

Iike many incidents in carrol1's life, this one is frustrating in its lack of further evidence. Was the a swindler? Had she been arrested for the crime, she might not have been convicted: no record of conviction has survived, and there seems to have been a common reluctance by nineteenth-century judges to convict upper and midalo-class women of such crimes. 25 How valla was UIImann": evaluation of her "political proclivities"? Party leaders Renneth Rayner and Jacob Broom certainly valued Carro11's oplnions. U11mann's opinion may have been sour grapes: after a11, 011mam had been defeated in 1854 , and bis party had just lost again. Anger at his party's failings might have taken the form of scorn ain Miss Carrol1"g claims to have done valuable worls for it. If she had tried to swincle hin or his acouaintances, that would nec@ssarily have colored his judgment of her political abilities as we11. Then again, it might have been a simple

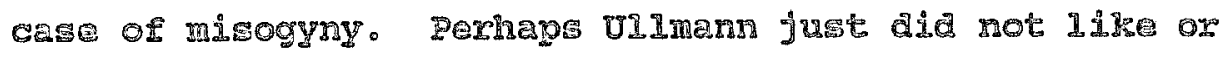
approve or "日political women". Why did F1Imose legp try ing to mplain his 
disapproval of her actions to Carroll? Why not just cut her off? Here again, a lack of evidence frustrates understanding. Perhaps, like all politicians, Fillmore preferred to withdraw with a door left slightly open. He might have viewed Ulimann's accusations as spite; he might have beex willing to give carroll. the benefit of the doubt kecause she was female and therefore, in his mind, not altogether responsibie for her actions. certainly, she reinforced his notlce of her femininity when she was in trouble. After the election she was a "power to propitate." After their guarrel, she was a "poor Iittle woman." 26 Perhaps he simply preferred, vain and ambitious and sensitive to sight as he was, to swallow Carroll's explanation whole, along with her everopresent flattery. If he chose to aimbelieve a part of what she said, at what poine could his guestioning stop-mbefore or after her pretty remaxls about his noble being? 27

What is alear in this incident was carroll's cholee to use her wex as a defonive weapon when it muited hex purpose. Gleary desjring to placate Fillmore, a powerful man stil I Ir Hew Lork and a useful contact for her, carroly took the easy way out by blaming her indiscretions on her

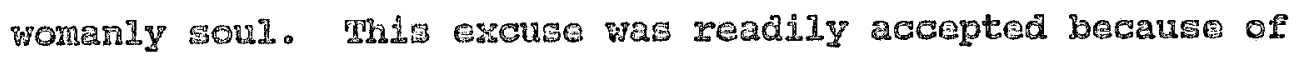
wideIyneld beliefs about che nature of womer, ana, further, it methodology of duty, apology, and personal petition, rather 
than woman's rights or equality.

I11 in January "from the effect of a continued use of ny brain \& a crowd of matters pressing on me... . until the slightest agitation vill . . . send my pulse to incredible speed," carroll postponed her tour west until the late spring. She revised The star of the West again, dedicating the thira edition to U.S. Navy Commodore Charles stewart, who wrote to thank her for her "generous espousal of the cause" of those still fighting the Naval Retirement Board. ${ }^{28}$ She was not particularly enamoured of the trip, which she was to take with her brother: "To think one like me should have to push my own Books is hard," she wrote, "but if my friends will stand true, I can do it like a lady \& make a competence." 29 By April, she had been to Washington and then was off to the Midwest, stopping in Chicago in june. 30 She mainitained her contacts with her New York city accuaintances, asking Thurlow weed to give one A. O. Alcock a job in the New York city Customs House. Weed was powerful in Ner York, but unlikely to have control of customs positions. mo matter to carmol1. she assumed power was power and it could be wielded where it was wanted. Is elways, she conched her demand for a patronage post in personal tems f"You heve kindly promised me your ajd -. - "I and appeared to have learned little from her experience with Finnore, as she included a sentence which cou2d be easily contrued as blackmail "The obligations I 
have placed [sic] certain parties, in withholding valuable information ...."). 31

As the anti-Catholicism of 1856 gave way in national pre-eminence to the slavery issue in 1857, Carroli thought of writing a book on the latter issue. She was apparently dissuaded by Kenneth Rayner's argument that passion had overruled reason on the matter. "I fear that the proper, the just, the constitutional view of the question would not please either section," he wrote. "Would there not then be danger of you hazarding the prestige you already have in the public estimation by your failure to accomplish that which I do not regard as within the scope of human achievement[?]"32 she worked instead for Maryland Governor Thomas Hieks election in $185 \%$ and agair in $1859 .^{33} \mathrm{AlsO}$ in 1859, she published pope or President?, another anti-Catholio text. once again, her goal wai to point out the danger facing Amarican institutions from the Roman Catholic Church in Americe. ". . some one should dare assume the responsibility of revealing the astounding migteries of the Vatican. We have al11owed its own writers to untangle the fearful meshes of their crafty and corrupt syeter." ghe "axtreme increality" of Arericans to believe in the Jesuitical threat had demanded she pubitish the works. 34

Considering Garge11' vanity and her known reputation as an anti-catrolio, pope or President? 
surprisingly, was published anonymously. Carroll may have chosen to hide her name and sex because of the lurid tales contained therein. She dealt with matters with which few women, and certainly no unmarried southern lady, should dare admit acquaintance. Tales of physical torture were bad enough, but storjes of incest, adultery, and mesalliances, oven wher couched in Vietorian euphemisms, made it clear the author knew what those terms meant. While carroll had clearly done her "research," though no doubt limiting it to unfavorable and anti-Catholic sources and citing evidence out of context, such a book presented to the public with a woman's name on the title page might cause as great an uproar as earider anti-Catholie works such as Maria Monle' 8 Awrul Disclosures. ${ }^{35}$ carroll's intention seems to have been wore scholarly than sensation-seeking. She took her Jesuitide conspiragjes seriously. She approached the groblem with the mind:- wet of the scholar and the argumentative style of a lawyer: ". - we now proced to

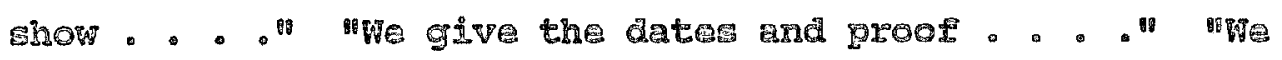
exiblt le... "* mour proofs will bo clear and Incontrovertble..." "We shall fortify our facts as we proced fron step to step, by the highest and most Incontestable proof: "36 Her goal was to sway the American public and, more directly and speatidealy. the Amerean

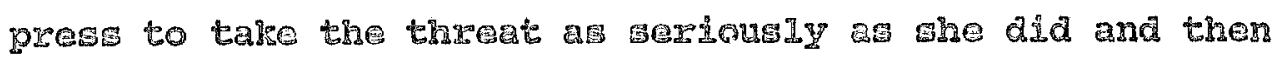
commit iterelf to the approprtate reaction. Sensationalism 
would not do for her purposes, and a woman as author would have raised quite a stir.

A second edition of The Great Mmerican Battle came out early in 1859. In March Carroll proposed a book on Dr. Robert Kane, the famous Arctic explorer who had died in 1857. She wrote to kis brother for approval of the project. ${ }^{37}$ By April, she had started the work as she resumed her correspondence with william seward, who was a nember of the Kane Monument Association. In that same letter to seward, she mentioned a work on Kansas that whe was preparing, "of Immense benefit to the Repulilican cause. ${ }^{38}$

This was the first evidence that carroll had apparenty dropped her allegiance to the American Party and turned to the Repubilans. Mris she maintained her a1leglante to the Ideas of the Know wothing party throughout her Iife, partlulary Ier mupport for Ite Unionist stand ard hex fear of the Jasuitio infuence in American politick she ras enough of polltician to realize that the Rnow-irothings were losang power. To maintain whatever influence she thought she had and to gain moxe, carroll had to exienc hergels beyond the Initg of the American Party.

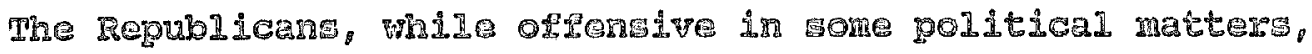
were a rising force in the Iand. carrold chowe to works with

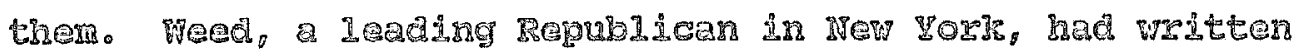
her a letser or zecommendeton to rorace Greeley. Je 
remarked that "though for some time Americanist," she had done, "and is doing, much for Republicanism." He commended her to Greeley's attention (and presumably his payroll). 39 But Carroll had not given up the Know-Nothings entirely. For as long as she could, she worked for both parties. Her goal war to elect a man to the White House in 1860 who coula serve the dideals of both parties. By April 1858, she had made her chotce: Jom Hinor Botts of Virginja. 40

Idke Fillmore, Botts appealed to carroll as a national candidate. "I know no north, no south, no Iast, no west: I only know my country, my whole country, and nothing but my country."Ai "There is nothing local about nim," carroll wrote. Mrhere if nothing wectional about him. He

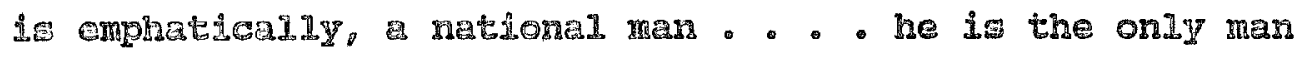
now left, who can occupy the position of such men as clay and webster." It might be "prematrre" to picis a cancidate as early as more than two years before a nominating convention, but it was going to be axceaingly alificult to End one who could "hamondie and unite the contending induences a.。.

By May 1., Carrold, mho had no doulat met Botts through the Amertoan Party, had becone his campaign menager. He sent her coples of his spaches: she was to send hin all ner press releages. ${ }^{43}$ Bottr was an experienced politician.

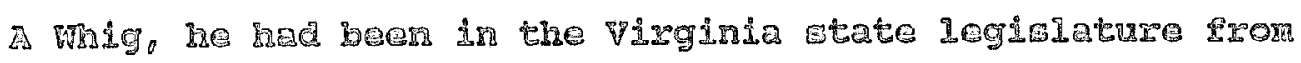
1833-1839, 3. the gouse of Represantatives from 1839-1843. 
then again from 1847-1849. 44 He was an anti-abolitionist, hated the Democrats, and held both groups responsible for the agitation throughout the country over the slavery issue. 45 He was not particularly enamored of foreigners and tended to take a conspiratorial view of Democratic party policies. 46 Most important to Carroll, though, was his pro-Union stance. He would, he had written, "make a willing sacrifice of myself, if, by so doing, I could save the Union and rescue my country from ruin. 47

The Ransas-Nebraska Bill had brought Botts out of retirement, and he had run unsuccessfully for congress as a Inow-Nothing in 1854. He continued to speak out publicly after his defeat, railing against abolitionist fanatics, disuntonists, and the "Democracy".48 Appealing as his opinions might be to some, like Fillmore, he was not the most charismatic of politicins. Carroll thougrt the overuse of his "gtrong reason" in his ageeches made hin "but Iltele undergtood by the general public." while most believed him to be brusque in his manner and uncaring toward his opposttion, "on the contrary," she argued, "he was thoroughly gefined and accomplished gentleman . . With mogt agreeable manners and . . most fluent and interesting in his conversation . . . . ${ }^{49}$ By 1859, CarrolI was concerned enough about Botts"

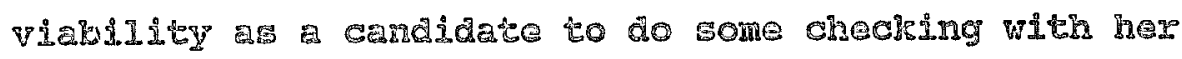
politica acguaintances. Thomas F. Clay, son of Henry clay 
of Kentucky and a know-Nothing in 1856, thought Botts a good choice, but only if "sectional issues" were "discarded" in the coning election. Buchanan was out of the question for the Democrats, he wrote, having "shewn himself worse than ever his most bitter political enemies had thought him." Seward and other Blacis Republicans, he thought, were "altogether impracticable" on the slavery issue. That left men Iifre Botts or Edward Bates of Missouri or John I. Crittenden of Rentudsy, behind whom all "conservative and retional men could unite." 50

Idward Bates, indeed, was a name being bandied about as a candidate. N. Ranney, a Democrat from St. Louis, wrote carrol that tren he would welcome Bates in the White House, should "the denocrats divide.. [and] the opposition . - .lect a President in 1860" something he thought undikely. ${ }^{51}$ carroll saw such comments from politicians as challenges to her candidate. She wrote lettris to newspapers, lauding Botts years in polities over Bater inesperience. 52 Josiah Polk, her friend and occasional landlord, wrote carroll from Washirgton that he too was pushing Botts candidacy to the Know-Nothings and Repubiticans. Botts could serve as the fusion candidate, instead of Bates or Know-Mothing John Be11 or Republican Seward. 53

Botts was cautiousiy optimistic and properly grateful to carrol, thanking her for "the mannex in which 
you have presented my name before the country." He realized that her work might not be reaching as many people as he needed to win a nomination, since, for instance, "the circulation of the [Inow-Nothing New York] Express is Iimited..." still, if he were denied the nomination, be thought, it would be "by the political machinery of the politicians, not public sentiment. 54

Carroli had gone to St. Louis in JuIy, presumably to measure Missourdan support for Botts canaidacy over favorite son Bates. She went on to chicago, where she had apparentiy made contact with rewspapers to supply them with prowotts articles. She missed the Fair there, but enjoyed 2 "providential scape from a burning car" during her journey. Carroli returned briefly to st. Louls, where her patarnel uncle charles lived. From there sho took the train across the courtry to New England. The trip was partly worle and party an escursion. carrol'"s health was not always the best, and her friend Poll mas "indeed rejoiced to learn that your health i. improved. This shows the benefit to You, of grexise and mental relmsation . . - Ivan the iron horses has [sic] to stop... now and then. ${ }^{855}$ Botts way begiming to $100 \%$ more and more Iija a winning candidate to carroll. Jacob Broom in PRiladelphia celled hin the man for the thmes glnce he was both a

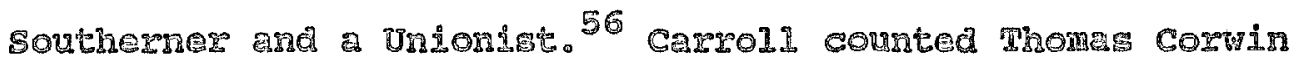
of Ohio in Bottg carg, though Benjand wade, Judge John 
McLean or Edward Bates would no doubt be considered more likely as Corwin's first choice. ${ }^{57}$ By November, Bates had "gone over, clean and clear to the Republican party," thought Botts, which would most likely serve to drive the Whig and Know-Nothing alements into Botts' camp. 58

carroll desperately wanted Botts to win. She had supported Fillmore and failed. Botts was her way back into power. But everyone in politics knew that william Henry Seward was destined to be the probable Republican nominee in 1860. Carroll would have to have been completely out of touch with political realities not to have realized that. She had chosen her candidate, certain, as always, that she had made the only cormect choice, and she was sure seward's abolitionism would destroy the country. So carroll Iied. She lied to herself, a necessary deception so she could continue her woxk for Botts. But she also lied to Botts。 Garroll told Botts that Thur'low weed, "in sacred confidence, had told her that "Governor s[eward] is as politicaliy dead as tho he were . . undergoing putgefaction in his greve, that he will not now be brought forward in the Convention, nor any other Republican." She cold him weed was "determined to nominate you if possible, " that Bott" prospects "never were so strong as now" As the campagn year began in eamest, however, Botts too had heard stom weed. Weed, he wrote carroli, had said only "thet in the event of thesi [Repulicand having to go South for a 
candidate--he would prefer me." Was this a change in Weed's views? "Under what pretense is it they have invited others [who] . . . are entirely cut off \& excluded from all possibility of a nomination?" Any fusion between Know-Nothings and Republicans was impossible under those circumstances. 59 Botts was not angry at carrol1, since he undoubtedly believed her incapable of such a deception regarding his chances. But he was furious at the Republicans for their refusal to consider any fusion candidate not a Republican.

Perhaps because carroll knew the degree of hatred the Rnow-Nothings felt towards Seward, she could interpret whatever comments Weed made to her regarding Botts as support for his candiacy. The virulent anti-Catholicism and nativism that had characterized the election of 1856 was still very much a part of the 1860 electoral campaign. Seward"s supporters faced letters such as the one 0. B. Vienz wrote to Weed that remarked on the "widespread and deep prejudice against seward on account of his action, as governor, on the public schools." 60 This referred to sevard's support nearly twenty years previously for publicefunded education for imigrants to be taught by M teachers speaking the same language. . and professing the mame faith." Parochial schools would receive public furch-a most unpopular idea 18 in 1840 as in the 1850 s, and a controversy that clung to Seward throughout his attompts to 
become a Presidential candidate. ${ }^{61}$ vienz urged weed to drop seward as a candidate. "The prejuclice [against him] pervades the entire protestant church . . . It is strongest with the clergy: but is showed more or less by the great body of the laity, even outside the council of the Inow Nothings . . while with the Americans, it is rankest--deepest-most bitter. ${ }^{162}$

But even know-Hothing Carroll could not ignore the primacy of the slavery issue in the campaign of 1860 . Sectional tension had increased greatly in the years from 1856 to 1859 , thanis to the Dred scott deaision, the civil war In IRensas, Preston Brooks' attagk on Charles Sumer in the senate, the Lecompton Constitution, and Johri Brown's raid on Harper's Ferry. As getional tensions rose, Inow-Nothings were forced elther to take a nationwide stance against slavery, thus loging Southern support to the Democrats, or to de-emphasize or lgnore the iswue, thus losing their northern support to the more inclusive Repubicans. The Know-Nothings had achiered their victories at state and Iocal levels because they had been able to appeal to nativist sentiments in the south and because they coula combine that appeal with anti-glavery-extension stands in the North. But the Republicans had, by 1860 , recognized netivism as an important politided drewing card and an issue that was not going to alsappear. Accoraingly. RepubIican

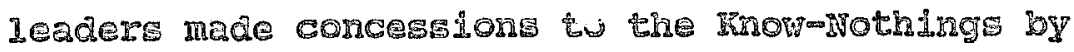


Incorporating a degree of nativism in their party pronouncements. Combined with their anti-slavery-extension philosophy and the Know-Nothings' abysmal performances in public office, Republicans would eventually gain enough support that northern Inow-Bvothings would shift alleglance to the Repubilican Party. 63

GIven the decline in wnow-Nothing power and the co-optation of theix ideas by the Republicans, carroll had adopted Botts, a IRnowothing but a strong Unionist, as a Logía I fusion candidate for president. But Botts was too unpopular in virginia, where thow-Hoting werse rapidy weakening, Hore important, he could not whole-heartedy adopt the antluLlavery-axtension plank of the Republican platrorm. Inenneth Rayner warned Carrold that unles: Botts could say "no extension" and mexn it, there would be no nonination。 opposition to sMavery artengion was now "aine gue non" and as much as Rayner had hoped for a "mion of the opposition to Democracy North south... Ors a conservative rational basis of organdzation... I doubt it such a thing be possiole."64 Botts was not willing to go far enough. In an extort at compromine, he was wiling to subscibe to the entre Republican party platform, except for the resolution regarding alevery extension. Where the platrorm called for no atencion in the territories, Botts wanted to inserc the mordi, "either by force, or rederal. legialation againg cin wid of the people of the 
territories.. . "With those "modifications," Butts did "not see why every Whig and American in the United States should not subscribe to the Republican platform." But his modifications would change the platform from absolute non-cytension to a form of popular sovereignty, a "modification" unacceptable to the Republicans. 65 Carroll went home for Christmas to Church creek, then back to New York city to discuss Botts future with Weed. She returned to pashington in January 1860. A friend from Hew Yori, Tohn B. Fry, wrote that he had heard she was "overzun by visters--the magnates of the land" at her parlox in Polk' boaxding house on Penssylvania Avenue. 66 And carrol 1 feasted on the news and gossip her visitors, including Jefferson Davis, Thomas Comin, and John sheman, brought her. The biggest topic in town was the speakership contest in the House of Representatives. The Iight had begur on Dacmise 5,2859 , and lasted until william Pensington was elected on February 1 , 1860 . carroll had difcussed the meter

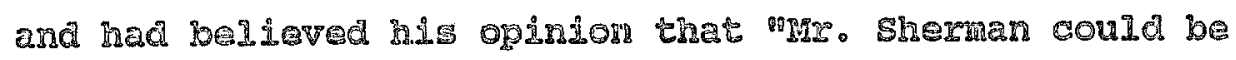
elected easier than any other of the party" and he was in Iact the candidate the Repubicans wanted as speairex. By the 27th, though, Carrol I had becone "acquainted with the Bossmen or the Repulicen, Southern opposition and Anti-Lecompton partes: and ar a friend thought it her "duty" to mrite to weed "though you do not to me." 67 
Sherman could not be elected, she wrote, and "I intend to tell him the whole truth as I know it and as no man .. woula ever tell him . . ." A union between Southern Know-Nothings and Democrats was forming that would destroy the Republicans-and Thurlow weed as we11, since it was thengs to his "interference" that sherman was still in the runsing and causing no end of trouble. Weed was to pull back from his support for sherman and push for thomas corrin of onio instead. corwin's name had already been suggested on January 17 by Roger A. Pryor of virginia as a compromise candidate. $^{68}$ weed must come to washington immediately and take charge of things, or he would "never survive the oblogng which will be heaped upon you if you allow a Republican organization to be defeated by the pergiatency of this pregent course." Carroll thought hexsel. fuly jugtidied In both her plans to tell sherman ali and to force weed to come to washington.

I feel that my position before the country, my Inowledge of whet I am about, my principles and my aincerity in the mantainance [sic] of Republican sentiments, whis I will cherish while I I ive (for better reasong than InILence you politicians enable me wo heard [gos:sp about the matter and was thus able to advise Sherman to withdraw as spealerer candiatel. - Fid make me indifferent even should Mr. Ginerman not adogt my wise and patriotic counsel. $I$ Ghall have the approval or my conscience and $m$ country hereafterwomen the whole party will feel the alnerul celemity wing wil come from their own doings OI those of bhe Leaderg to whor the matter 16 entarusted.

CarroIl was growding bit dewperate. she had spent 
over three years trying to force a fusion of Know-Nothings and Republicans. She had spent nearly two years pushing Botts for the presidency, with no real sign of seward losing support from major Republican leaders. Weed was not returning her letters, even if he did consent to see her occasionally when they were in the same city. Botts as a eandidate seemed to be out, and Carroll wanted in. The Speakerghip contest provided her a way. Thomas corwin was an old and intimate friend: if he vere elected Spearer, surely not only some of his glory, but some patronage would Fag hex way.

Carroll may have seen this election year as her last chance. She was, after 311 , forty-five years old. Her party had almost entirely lost its place in politics: friends and acguaintarces, talking her word at face value about het Influerce, were hounding her for jobs: she nerself was chronically short of Pund and, as alvays, concerned about her family. She was also growing dea. For 2. woman whose me

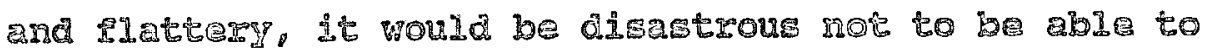
participate in the political discussions that made heI parlor so IIvely and provided ser entre into the politicai world whe 10ved. 70 The year 2860 becme frantic one ror Carroll as she seareher som the next President to latah onto

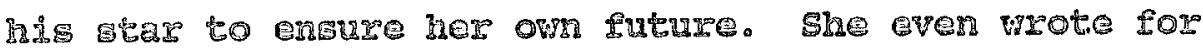
Farnando wood, the Dougheace Democratic Inyor of Mer York, 
suggesting he be a candidate for president. Wood thanked her for "keeping his name before the public" and acknowledged draft attempts, but laughingly remarked that "but for the common sense my mother gave me I should be made dizzy" by such attention. He would be satisfied with a seat at his party's nominating convention. " 11

Besides her own self-interest, though, Carroll was still vitally concerned with the preservation of the country srrom the agitation that seemed ready to tear it apart. She supported Wood because of his stand against the agitation promised by anti-slavery Republicans. 72 By March she had written to Weed again, telling him neither seward nor Bates would take the nomination, and therefore Botts "is your orly man." If that were imposeible (Carroll's first admission of doubt). Botts would be willing to accept the vice-presidency whdex Judge McLean. MoLean's age, 75 , was a major factor in considering his candidacy. carroll dismissed it rather callously, deciding that "If keIean did die, the North would have as good a friend" with Botts in the White Houss as ever seward woula be. 73

In April, Carroll wrote to weed once more, teling him that McLean would be nominated at the constitutional Union Party"s convention in Baltimore on Nay 9 , and that "he Is the orly man who can defeat the democracy." For the vice-president, she wanted weed to "Iet it be . Botts... You have got more power than they 
[the Constitutional Union party members] will have: even in their own party! For you can regulate the Republicans."74 If Weed did have the power over the constitutional Unionists, he chose not to exercise it for carroll's candidates. The constitutional usion Party's candidates would be John Bell, with Idwara Everett as his vice-presidential running-mate. McIean and Botts were both nominated in the convention, but won only 21 and $91 / 2$ votes on the first ballot respoctively: they aropped to $I$ and 7 respectively on the second ballot. Carroll, in reeping with hex search for power in the winning party, cuickly wrote a congratulatory note to Everett. 75

It could not have been too much of a surgrise to Carroll that Botts hat not been nominated in Baltimore. He Bimself Iad given up by hay 1 , writing sady that " - al hops, expectation and.. desire has pretty well aied out, " and my name not mentioned with approval in any one.. It Iools to me very much Iise the game is up. 76 put phurlow weed"g inability to "regulate the Repubicans" at the Chicago convention must have shocked carroll. She had worked hard to establish a Ielationship with both weed and

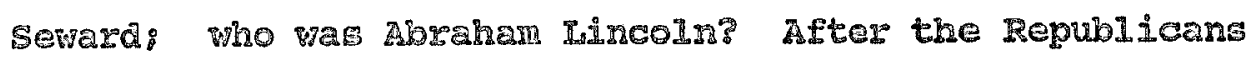
sominated Incoln on Hay 18, she must have been in despair. She had gone home to Church Creek, when John wilson, another boarder at POI"' 
were "quiet and dull without you." He held out a crumb of hope: Bell's prospects were brightening, he thought, since Iincoln's nomination would necessarily mean the alienation of votes in New York, Ohio, Pennsylvania, and Massachusetts, which states had had their favorite sons eliminated by the dark sorse from IIIinois. 77

By June, no doubt exhausted, Carroll had fallen ill and could follow the campaign only through letters from pols and other friends. By september she had recovered, but her sistex Julianna had died during her stay in church creel. Botts successfully predicted Lincoln's election to her, and prophesied the immediate secession of the south upon the commission of any "aggressive act" by the new President. Carroll herself was soon ready to "speak of the Union as already dissolved." ${ }^{78}$ she returned to washington, needing to discover where she covld fit in with the new administration, onIy to be met with another 1oss. The National Intelligiencer announced the death of former Maryland Representative John $\mathrm{M}$. S. Causin. 79

Johi Causin had apparently met carroll in chicago about 1858. She may have known him from his earlier political career in Haryland. He had been to visit his family in Argansae and was retuming to his law practice in Chicago man aied of apoplexy. In three letters from causin's brother-iriaw to carrold, their relationship as Intimate frionds and probably lovers survivec. 
Causin's brother-in-law, I. E. Barber, wrote gently of John's death to Carroll, and of the death of his mother as she had walted for her son's body to come home. Aware that causin had "regarded you with affectionate esteem," Balber promised Carroll that he would return her letters. Carroll wrote to request a copy of causin's last speech and when Barber replied, he suggested he burn her letters. There were "many-yery many of them," and he had accidentally read one "at a part which gave full expression to the feelings of the writer-the whole heart was bare before me." He was embarrassed by the incident and worried about sending them through the mail: "it would be mortifying if by any accident your letters should fall into obher hands. 80

Carroll, relieved at his discretion, requested Barber burn the letters. She also asked him to "suspend juagment" unt11 he "knew the facts" regarding hex affais" with cansin. Baxber assured her he coula not conceive that thelr relationship, whatever it might have been, coula "aepreciate you in our estimation... Can It be that I woula estimate less one whon he loved for retuming that Love!" While Barber could not "altogether acguit [Causin] of imprudence and of wealness in this respect, "he hastily reassured carroll of hes innowence in his eyes. "I know nothing, believe nothing, suspect noting. . other than tre Bimple fact that there aristed a mutual affection." He 
enclosed locks of hair from both Causin and his mother, thanked her for allowing his sister to keep carroll's daguerreotype, and sent her violets from the graves of the dead. $^{81}$

Carroll had suffered greatly during 1860 and early 1861. Her work would heip her recover. III health, mourning for the 10ss of Julianna and Causin, and despair at the turn of events in her Iife had kept her quiescent for a time, but the growing chreat to her beloved Union would soon galvanize her into action. 


\section{Notes}

${ }^{I_{S}}$ ince Fillmore was the nominal head of a party that had split over the slavery question in the 1856 nominating process, and since Fillmore's embrace of Know-Nothingism was lukewarm et best, Carroll's observation was optimistic and inaccurate. While Fillmore stressed the Union in his campaign speeches, and seldom mentioned slavery, the party's decision to take the popular-sovereignty position regarding slavery extension split tine party in convention and in the fall election. congressional quarterly, Guide to U. B. Elections (Washington DC: congressional Quarterly, Inc., 1975) p. 13; Carleton Beals, Brass-Knuckle crusade: The Great Trow-Nothing Conspiracy $1820-1860$ (New Yorts: Hastings House Publishers, 1960), pp. 180-181; Ray A11en Bi11ington, The Protestant Crusade 1800-1860 (New Yori: Rinehart \& Co." Inc., 1952), pp. 428-429.

${ }^{2}$ Anna Ella Carroll to Killara Fillmore, 6 November 1856. Millard Filimore Bapers, Buffalo and Erie County Historical society and state university college at oswego, Oswego, New York.

3 Rennetr Rayner to Amra Fla Carroll, I4 November 1856, Anna E1 Ia Carroll Papex, Maxyland Historical Society, Baltimore, Maryland.

AAnna IIIIa Carrol1 to Mi11ard Fillmore, 16 November 1856. Fillmore Papers. of the three works carroli mentions, presumably she was referring to GAB and The star of the West. The third work may have been one of her campaign pamphiets or perhaps a thirc, unimown work.

$5_{\text {See, for esample, the testimonial dinner offered }}$ sterding Price by the aldermen of Jefferson City, Missouri. Dinners Iife these could serve more than one purpose. This one was to honor Price's term as governor, to propitiate those who beljeved Price should have been nominated to the Fouse of Representatives, and to keep Price's political. profile high. Price, incidentally, refused the honor.

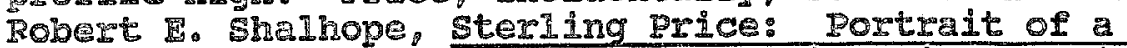
Southerner folumbia, Missouri: University of Missouri Press, 1971) , p. 133.

Gradeline B. Stern, editor, Publishers Eor Mass 
Entertainment in Nineteenth Century America (Boston: G. K. Hall \& Co., 1980), Pp. 93-96.

${ }^{7}$ Jeremy Didaler was a character in the 1803 farce Raising the wind by Englishman James Kenney. He borrowed money and failed to pay it back. See charles Mccool Snyder, "Anna Ella Carroll, Political strategist and Gadfly to President Fillmore," Maryland Historical Magazine 68 (Spring 2973 : 53 , II. 51.

${ }^{8}$ Daniel vilmann to Nillara Fillmore, 25 november 1356, Fillmore Papers.

IAnna Ella carroll to Millard Fillmore, 5 December 1856, Fillmore Papers.

10 Mepspaper alpping enclosed in letter, Ana Ella Carrol 1 to ThurL ow Weed, 11 December 1856, Thurlow Weed Papers, Department of Rare Boolss and Special Collections, Rus Rhees Library, University of Rochester, Rochester, New York. (Herearter cited as Weed Papers.)

11[1]Iim] s[cudder] Tisale to Millard Fillmore, 8 December 1856, Filimore Papers.

12 Hillard Fil1more to Daniel U11mann, 9 December 1856. Filimore Papers.

13 Danded v1Iman to Millara Fillmore, 10 December 1456, Filimore Papers.

14. Arna ElIa Carrol1 to Thur IOW Weed, 17 Apri1 1856

and 11 December 1856 , Weed Papers.

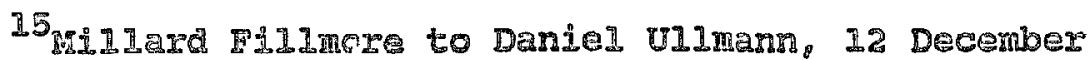
1856. FIIImore Papert.

16 Jacob Broor to Millard Filnore, 15 December 1856, Fidmore Papers.

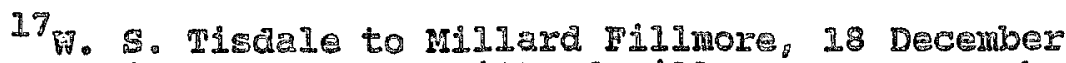
1856: Daniel U1Imans to Mi1lard FiI1more, 18 December 1856, Fillmore Papers.

18 Ama FIIa Carroll to millard Fillmore, 18 December 1856, Fillmore Papers. No book of this title has been found, but $a$ forn letter soliciting information and contributions does esist. The letter. sigsed by risdale and promoting Garrol1 as aubhor of The Great Emerican Battle (see chepter 2 abova) as wed as the proposed work was 
apparently sent to a number of know-Nothings, and included the names of the leaders of the Party. For a subscription price high enough to include the cost of printing an engraving, participants could become a part of the book. see Undated Advertisement, MDHS 3655-703, Carroll Papers.

${ }^{19}$ Samuel st. John, Jr., to Millard Fillmore, 18 December 1856, Fillmore Papers.

${ }^{20}$ Anna El.la Carroll to Millard Fillmore, 22 December 1856, Fillmore Papers.

2.1 Millard Fillmore to Anna Ella carroll, 27 December 1856, Eillmore Papers.

22 Anna Ella Carroll to Millard Fillmore, 1 January 1857, Fillmore Papers.

23 Hillard Fillnore to Anna Ella Carroll, 10 January 1857, Fillmore Papers.

24. Anna Fila Carroll to Nillard Filimore, 16 January 1857. Filimore Papers. Iater letters from Tisdale to Carroll make it clear that some sort of relationship survived this imbroglio. See Tisdale to Anna Ella Carroll, 23 August 1879, 19 september 1879, Carroll Papers.

25 The 1856 Minute Booss of the City and County of New yorls courts reveals nothing on carroll. Joseph Van Nostrand, Archivist, office of county clerk and clers of the supreme court, to author, 8 March 1285. For an examination of judges" rejuctance to convict midale and upper-class women of sone crimes, see Elaine Abelson, "When Ladies co A-Thieving: The Middle-class women in the Department store, 1870-1914," (Paper delivered at Faoing the Future: Graduate student conference on Scholarship on women, yale university, New Heven, Connecticut, Apri1 13, 1985).

26 Carro11 waw emphatiealy rot a woman's rights worker (see Chapter 2 above). The 19th-century cultural imperative that all women needed a man to watch over tham. along with carrol' 's occasional references to Fillmore as a father-figure, would make it easy for Fjlimore to assume a paternalistic attitude towara Carroll's actions. See Anna G11 Carroll to Millard Filimore, 7 Harch 1853, i2 October 1853, Fl1Imore Papers.

27 Gyndon G. Van Deusen, Thur 10 Weed: Wizard of the Lobloy (Boston: IIttle, Biom \& 60. 1947), PP. 93, 15I. Robere J. Rayback, MIIIard F111more: BLography of a 
President (Buffalo: Buffalo Historical Society, 1959), is the best existing biography of this little-known president, and the only modern one. W. $I$. Barre, The Life and Fublic Services of Millard Fillmore (New York: Burt Franklin, 1856; reprint ed., New York: Ienox Hill Pub. \& Dist. Co., 1971) is a campaign biography, as is the only other fuli-length work on Filimore, [Ivory Chamberlain], Biography of Fillmore (Buffalo: n.p., 1856).

${ }^{28}$ Anna Ella Carroll to Millard Fillmore, 16 January 1857, Filimore Papers; Snyaer "Anna Elia Carroll," p. 59, n. 64: Anna Ella Carroll to Millard Fillmore, 5 September 1857. Fillmore Papers: Charles stewart to Anna Ella Carrol1, I8 Apri1 1857, Carroll Papers. The "cause" was one that dragged on and on, prompting the New York Times to remars in April of 1858 that, while they had occasionally flattered themselves that the country was rid of it, it would not die. "It would have been the cheapest and best way to have reinstated all the officers in the beginning. and then tried each of them in detail by a separated [sic] Court-Martial. It would have saved the country some hundreds of thousands of dollars, and been much better for the Havy" New York Times, 26 Apri1 1858.

29 Anna Ella Carroll to Thurlow Weed, 11 December 1856. Weed Papers.

30 I [O 185\%, Carroll Papers. Book tours by women authors were not unheard of: for another description see Kathryn Kish S1:ar, Catherine Beecher: A Study in American Domesticity (New Haven, Connecticut: Yale University Press, 2973), p. 215.

3I arra Ella Carroll to Thur Low Weed, 11 June 1857. Weed Papers.

32 genneth Rayner to Mnna MIIa Carsoli, I October 1857, Carrol1 Papers.

${ }^{33}$ conclusive proof of Carroll's activities on behale of Higls does not exist. Family tradition held it true, and it seems logical to assume carroll would work to elect Hicks, a Know-Nothing and a former neighbor. See Marjorie Bazstow Greanbie, My Dear Lady (Now York: McGran Hi11, 1940): 75.

34 [Anar FIIa Carroll], POpe or President? starting Disclosures of Romanism $\mathrm{As}$ Revealed By Its own Writers. Facts for Americans (New Yorg: R. L. Delismex, 1859), p. Vi. Cerroll estabIdshed her authorship of this book in 
letter to the Rev. Dr. Robert Breckinridge, 29 November 1864, Breckinridge Family Papers, Library of Congress, Washington, DC. She sent him a copy of her book by way of his nephew, John C. Breckinridge, while John was vice-President under James Buchanan.

${ }^{35}$ Allan Nevins, ordeal of the Union: A House Dividing, 1852-1857 (New York: Charles Scribner's Sons, 1947), pp. 403-404.

${ }^{36}$ Carro11, Pope or President? pp. 9-10.

${ }^{37}$ Anna I1La Carroll to Robert Kane, 5 March 1859, Carrol1 Papers.

${ }^{38}$ The second edition of The Great American Battle was printed by C. M. Saxton in New York in 1859. See walter P. Armstrong, "The story of Anna Flia carroll: politician, Lawyer and Secret Agent, "Anerican Bar Association

Journal 35 (March 1949):199, n. 2. Ama Ella Carroll to William Henry Seward, 23 April 1359, william Henry Seward Papers, Rus Rhees Iibrary, University of Rochester, Bochester, New York. The outside of the kane letter bears a note in Carrol1's hand that the project was interrupted by the civil War and never completed.

$39_{\text {rhur }}$ low weed to Horace Greeley, 19 october?. Carro11 Papers.

40 Amna Flla Carrol1, Eaitorial, Louisville Journal, signed "E. Pluribus Umm, "ited in letter, John Minor Botts to Anna III Carro11, II May 1858, Carro11 Papers. The Journal was a Inow-Nothisg paper and printed a number of articles by carrol1.

AIJon minor Botts, The Great Rebel110n: Its secret History, Rise, Rrogress, and DLsastrous Fallure (New Yorks: Harper \& Brothers, Publishers, 1866), frontispiece.

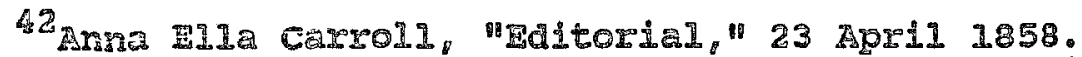
This wes a rough draft, and no place of publication is indicated.

43 Johr Minor Botts to Anne Ella Carrol1, I1 May 1858, Carzol1 Papers.

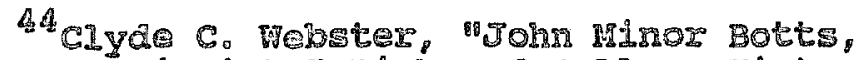

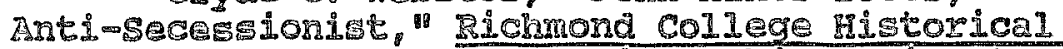

Papers i forne 1915/:10: Blographical Directory of the American Congress, 2774 m 1971 Phashington, DC: Government 
Printing office, 1971), p. 614.

45 webster, "Botts," pp. 11-13; Botts, The Great Rebellion, pp. $66,162-165$.

${ }^{46}$ Botts, The Great Rebellion, pp. 127-128, 144-147; Webster, "Botts," p. 13 .

47 Botts, The Great Rebellion, p. 66; "John Minor Botts," Dictionary of American Biography, ed. Allen Johnson, 12 vol: (NeV Yorg: Chardes Scribner's Sons, 1964-1975), 1(1964):472-473.

48 Webster, "Botts, "pp. 22-25.

49 Anna Ella Carroll, "Slsetch on John Hinor Botts," n.d. [post 1869], MDHs 3649-93, Carroll papers, Few of carroli's papers from 1858 survive, but it is apparent she wrote Botts falrly often that year, as well as printing as many articles supporting him as she could. Publishing matters no doubt occupied most of the rest of her time.

50 Thomas H. Clay, Jr. to Anna Ella Carroll, 16 Apri1 1859, Carrol1 Papers.

$5 I_{\mathrm{N}}$. Ranney to Anna Ella Carro11, 29 June 1859, Carroll Papers.

52 Anna Fila Carro11. "Letter to Editors," New Yors Jxpress, Eigned "Hancock, "undated clipping found in an October 1898 letter, ? to Mrg. Thomas Cradecls, MDHS 3655-676, Camsoll Dapers. The "1Hancock" paeudony in the Frmpress was referred to by Botts in a lettars to caxroll, 29 June 1859, Carrol1 Papers.

53 I. F。 Polk to Anna L1L Carrol1, 3 August 1859, Cargol Paper:

54 John minor Botts to Anna Fida Carall, 6 August 1859, Cavrol1 Paperg.

55 John Minor Botts to Anne Ella Carroll, 9 october 1859: J. Fo Poll to Anna F11a Carroll, 11 October 1859, Carroll Pagers. mhe reference here is presumably to the National Fair in Chicago in 1859. See Murat Falstead, Caucuses of 1860 (Columbus, Osio: Follett, Foster \& co.r $28608, p .122$.

56 Jacob Broom to Anne Tla carso11, 26 october 1859, Carro11 Raper: 
57 John Minor Botts to Anna Ella Carroll, 6 November 1859, Carroll Papers; Reinhard H. Iuthin, The First Iincoln Campaign (Gloucester, Massachusetts: Peter Smith, 1964; reprint ed., Cambridge, Massachusetts: Harvard University press, 1964), p. 162. Corwin nominated MoLean at the Convention, supported Bates and Wade. Halstead remarked on corwin's "Covetous glances" at Wade's senate chair as the real reason for Corwin's support of Wade's candidacy. See Allan Nevins, the Emergence of Lincoln: Prologue to Civil War, 1859-1861 (New York: Charles Scribner's Sons, 1950), p. 53; Halstead, Caucuses of 1860, pp. 143-144.

58 John Hinor Botts to Anna Ella Carroll, 12 Hovember 1859 and 16 November 1859: Anna Ella Carroli to John Minor Botts, 18 and 20 November 1859 (one letter), Carroll Papers: Harriet 2. Weed, ed., Iife of Thurlow Weed, 2 vols. (Boston: Houghton, Mifflin \& Co., 1883 ; reprint ed., New York: Da Capo Press, 1970), 1:602; Nevins, Prologue to Civil War, pp. 247-259: Halstead, caucuses of 1860, pp. 140-141.

59 John Inor Botts to Anna Ella Carrol1, 1 January 1860, Carroll Papers.

60 . B. Vienz (?) to Thurlow Weed, 27 November 1858 , Thux low Peed Dapors, Iibrazy of Congress, Washington, DC. (Hereafter referred to as Weed-LC Papers.)

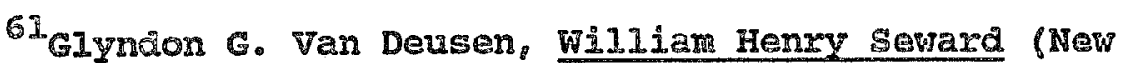
work: Orford vniversity Press, 1967), pp. 67-71.

62 o. B. Vhene to Thurlow Fyeed, 27 November 1858, meeduc Papers. See also wi11 iam $\mathrm{i}$. Gienapp, "Nativism and the creation of a Republican Majority in the North before the civil $1985): 553$.

${ }^{63}$ cienapp. "Nativism," po 537. Gienapp forcelully axgues this position, saying that ithe political reality of the Inownothings' strength, if nothing else, dietated the necessity of seeking a fusion with anti-slavery supporters of the Ameroican organidation. Simon cameron. Nathaniel. Banls, David rilmot, schuyler celiar, and Edward Bates were all former Know-Nothings who became Republicans between 1856 and 1860 . Fren Thurlow weed was wilidng to include sone nativing xemers:s to attract Filmoreites in an attempt to prevent Democratic victories in off-year elections in New York. See pro 540,547-548, 556,558-559. See also Exic Foner, Free Soil. Free Labor, Free Men: The ICeology of the Republ 16ar Party Bafore the CIVII War (New Torls: osfora University Press, 1970), pp. 248-260; Harry I. Carman and 
Richard H. Iuthin, "Some Aspects of the Know-Nothing Movement Reconsidered," South Atlantic

Quarterly 39 (1940)::229-230. W. Darrell overdyke holds that the know-Nothing party succumbed partly because of their failure to take a clearly sectional stand at a point when only sectional stands covid attract mass allegiance to a political party. See his the know-Nothing Party ir the South (Baton Rouge, Louisiana: Louisiana state University Press, 1950), p. 294. For discussions of fusion attempts between Know-Nothings and Republicans, see Michael F. IIolt, Forging a Majoxity: The Foxmation of the Republican Party in pittsburgh, 1848-2860 (New Haven, Connecticut: Yale University Press, 1969). pp. 175-183; Michael F. Holt, rhe Political Crisis of the 1850 s (New York: John Wiley \& Sins, 1978) pp. 175-181: Stephen E. Maizlish "The Meaning of Nativism and the Cxisis of the Union: The Know-Nothing Movement in the Antebellum North," in Essays on Amerlean Antebellum Politios, 1840-1860, d. Stephen E. Maizlish and John J. Kushma (College Station, Texas: University of Texas at Arlington by Texas A \& university Press, 1982J, pp. $166-198$.

64 Tenneth Rayner to Anna Ella Carrol1, 23 November 1859, Carroll Papers.

65 John Winor Bottg to Arna El1a Carrol1, 24 December 1859. Carrol1 Papers: Fmerson David Fite, The Eresidential Campaign of 1860 (New York: Mackid1an, 1911), pg. 23\%-240.

66

John D. Ery to Anna Ella Carroll, 5 January 1860. Carro1 1 Dapers.

67 Anne TIa carrolI to Thurlow Weed, 27 January 1860 . meed Eapers.

68 Ol1inger crensin,

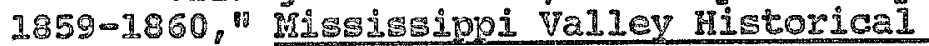

Review 29 (December 1942):327.

69 Arna Flda Carroll to Thurlow Weed, 27 January 1860, พืeed Papers.

70 Garoll had apparently either never beer paid or been paid ICss then whet she shought her work was worth by the know Mothings 2 in 2856 (See chapter 2 above) . She was determined not to Iepeat that mintalp: MM abi11ty as a writer is conceded by mer of 11 partes and $I$ don't mean ever to throw yn time and talent away for any canse again," rise mpote to Heed, after demanding she be well \& handsonely paid for my service by the opposition, by which I mean your 
Party." Anna Ella Carroll to Thurlow Weed, 20 April 1860, Weed papers. There is no evidence as to the result of her bill to Weed. Both Fry and Polk asked her to help them find positions: J. B. Fry to Anna Ella Carroll, 5 January 1860; J. F. Polk to Anna Ella Carrnll, 5 August 1859, Carroll Papers. Carroll's deafness came on gradually: by 1865 it was bad enough that $R$. W. Mundy warned a senator in a letter of introduction to be sure to speak up; by 1890 , she was completely deaf. See R. W. Mundy[?] to senator ?, 28 september 1865, Carroll Papers: Sarah Ellen Blackwell, Iife and Writings of Anna Ella Carroll (Washington, DC: Judd \& Detweiler, 1895). po 135 .

71 Fernando Wood to Anne E11a Carro11, 30 Jamuary 1860, Carrol1 Paper:; Carrol1. Letter to Editor, New York Daily NewE, 27 February 1850, signed "Madison."

72 Samul Augustus Pleasants, Fernando wood of $\mathrm{Her}$ Yorrin, (NeW York: AMs Press, Inc. 1966), pp. 95-101.

73 Anna FIla Carroll to Thurlow weed, 24 March 1860. weed Rapers.

74 Anne Dlla Carrold to Thurlow Feed, 20 April 1860, Weed Papers.

75 Horace Greeley and John $\mathrm{T}$. Cleveland, A Politicel Textbook for 1860: Comprising a Brief View of Presidential

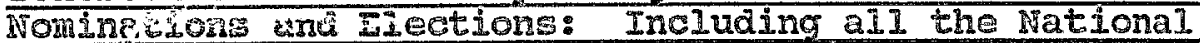
Platiorms iver let Adopted: Also A Historg of the Struggle Respeating SIavery in the perritories, and of the detion of Congress As to the Freedon of the Public Lands with the Most Notable Speeches and Letters of Messrs. Liricoln, Dovelas, Bell, Cass, Seward, Everett, Brecrinrider, H. V. Johnson, ete., etc., Touching on the questions of tire Day: and Returns of 111 Exesidential Elections Since 1836 (New York: The Tribune Association, 2860) p. 29: Farara Everete to Anna Ella Carroll, 29 May 1860, Carroll Papers.

76 John Minor Botis to Anse Ela Carroli, 1 May 1860 , Carroll Papers.

77 Jom wilson to Anne IIL Carro11, 21 May 1860, carrol1 Papers. Carroll had at least a nodding acquaintance (though undoubtediy she worla consider it more intimate) with Rdward tverete prior to his selection as John Bel' ruming mate, having written him regarding her anti-slavery activitides In the early 1850s.

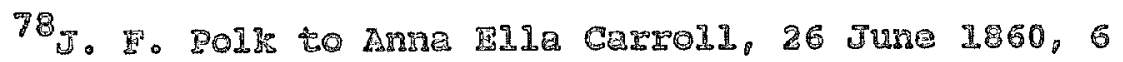


July 1860; John Minor Botts to Anna Ella Carroll, 2 September 1860; William Orton to Anna Ella Carroll, 1 December 1860, Carroll Papers.

79 National Intelligencer, 6 February 1861 .

${ }^{80}$ I. E. Barbex to Anna Ella Carroll, 18 February 1861, 12 April 1861, Anna F1la Carroll Papers, Carro11, Cradocr, Jensen Collection, Maryland Historical society, Baltimore, Maryland; Biographical Directory of the American Congress, p. 719.

8II. E. Barber to Anna ElIa Carrol1, 14 May 1861, Carroll Papers, CCI Collection. 


\section{Chapter 4}

"To Preserve This Union...."

With the lection of Abraham Iincoln, Anne Carroll feared for the very existence of the Union. "I have no doubt, " she wrote in November 1860 , that his election would "Iead to an attempt on the part of the southern Ieaders to dissolve this union." Convinced that the secession of her home state of Haryland would mean the destruction of the Union, she urged Governor Thomes Hicks to stand firm against secessionists. "ylthough you vere opposed to the election of Mr. Lincoln, you are for maintaining this Union, ${ }^{\text {phe }}$ reninded him. Iincoln had been "constitutionally elected and a - must be inarguzated on the ath of next March, as the President of the whole U.S." A succesful inauguration depended "xore upon your individual fimmess then upon al1

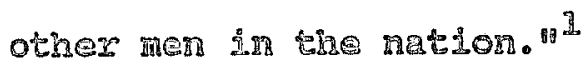

Carrol1 may have overstated the importence of Hicls: position, but not the Luportance of Ireeping Maryland in the 
Union. If Maryland seceded, the capital of the United States would be cut off from the North. The loss of the capital could mean the loss of the Union as well. ${ }^{2}$ Both sides wanted Maryland, and in the early days of the secession crisis, no one was sure how the state would go. one party who may not have been sure was Governor Hicls himself.

Hicks was a slaveholder from the Eastern Shore county of Dorchester. Fe considered hirself a southerner. and, as dia many Eastern shore residents, resented the primacy of Baltimore city in state matters. In the state's constitutional convention in 1850-1851, Hicks had been disenchanted enough to call for the mecession of the Eastern Shore, but only from Maryland to another stete, not from the United staces. ${ }^{3}$ Hioks persondfied the schizoid nature of Maryland. He supported slavery, saying at one polmt that he had "never lived, and should be sorry to be obliged to Iive, in a state where slavery does not axist, and I never will do so it I can avoid it. on the oher nand, as a Knownothing he had been elected as governor on a Unionist tialet. Slavenolder and Unionist: the two political characteristias were fast becoming uncomortable for politicians. Ricks, Iire his state, mas Gaght in the mida1e. 5

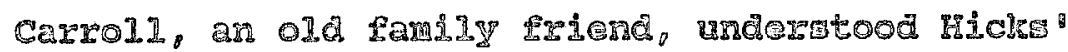

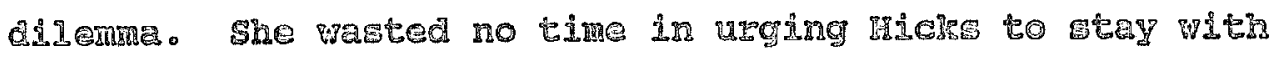


the Union. She wrote first from New York City, then from Washington, where she took up residence as congress convened in December. Over the five months between the election and the outbreak of war, she alternated between Maryland and Washington affairs, trying hard to stay in touch with matters in both areas. Host of her attention focused on Maryland, where the issue of secession had become the issue of whether or not to call the legislature into special session. Hidss had refused. The Democrats, who thought they could push a call for a secession convention through a special session, petitioned Hicks. 6 After a "fair, frank, rational examination of the subject," he told leading Maryland secessionists he could discover no necessity to convene the Iregislacure in gpecial session. The expense Was unnecessary, the weather inclement. Further, the IIgellhood was that those called would spend time spending money instead of solving the "so-called" crisis, and Maryland was already $\$ 50,000$ in debt from the previous session. Haks counselled patience. He urged secession Ieaders to wait to see what the other states would do, to allow congress to convene and take action, to let the inaugurat rebuffed tentative approaches from the southern states, tusning dow south Carolng's allegediy innocent invitation to join with the Palmetto state in a day of Lasting and prayer. He hed already scheduled one and could not change 
the date, Hicks replied, but he was sure that the people of Maryland would "unite, heartily with the same purpose . . in imploring God's blessing and direction in this hour of difficulty." 9

Carrol1 rept in touch with Hicks often auring this period, passing along information and articles from Washington nwspapers. It was a difficult ime for the govemor: "the waves of secession and rebellion are beating with great fury upon the frad bark of our state's executive," and he was "borne down at the same time by domestic affictions almost without a paraldel"-the death of his daughter. ${ }^{10}$ Eutting his personal crisis aside, by the first of the year Hicks was ready with a message to the people of his state that enumexated what had been done since the lection and what would be done in the future.

He had, Hiciss said, consulted with the other border states. He was inclined to wait to take any action in concert with them. South carolina's reasons for seceding pere not good enough to persuade him to join that state in secems should not be the sovereign state of Maryland" for wuch a arastic step. No, Incoln had not promiged him an office if the state were gept in the Union. In spite of his lack of support for Inirooln and his party in the late

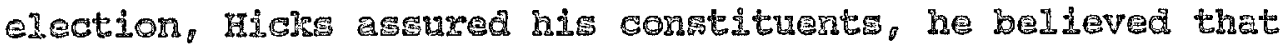
the Union, even under Repubicen rule, would guarante the 
protection of slavery within Maryland. He added one more reason for patience. Considering the state's geographic location, any war within its borders would be so destructive that it behooved him to give its citizens "time to breathe" and "try every honorable plan... to avert the necessity of War..." He had two cholces: "to allow Maryland to IIIde into the ranks of the seceded states, " after it had been "hurriedly borne along into the turmoil of the political movements of the day," or, far better, "to wait with calmness the progress of events." 11

Rlthough pressure from secessionists for calling the legislature continued in Jamary, so did conejilitory measures-and so did support for Hidrs. one of his most ardert supporters was carrol1, as whe used ber "rended relation with the leading Presses of the country" "to create a public opinion favorable to your course of patriotic action throughout the land. 12 The support was welcome, but richs, tirea of "the harassings of calculating demagogues (and they are terrible) "xpressed the "incere wish that congress may carly do womething to stave off and

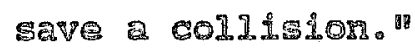

will not the representatives fron the Border states go at once to work and expect something as a maIvo and wild not the Hortherr representatives yield more for thel comery ${ }^{\prime}$ sarety? They have the power, will they not ajaplay the needed magnaninjty and pass conciliatory measures and put the Gouthern estremists at favit? This I ธay as a Southern man. The Southern ratremists 
quarter, but not so, the masses. And how easy a matter for Northern members to unite with conservative Border state members and the few worthies from the far South and pass a proposition of that good laboring man Crittenden or some such measure to stave off until the people 3 can have light and the fourth of March is past.

Such firmmess of position and such obvious, if overly optimistic, hope for reconciliation impressed Carroll. She

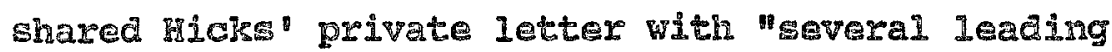
Bepublican Senators \& memers" and was pleased to be able to lay a fev rumors of Haxyand's impending secession to rest. Maryland would come out of this trial "Iike gold seven times purified," she thought. Even if virginia did go with the South "which [state], in spite of the secessionists I am privately assured is true to the Union) I can see no reason mhy Haryland should cast her destiny with her." What would come next, she was not sure, Lor John I. Crittenden"s

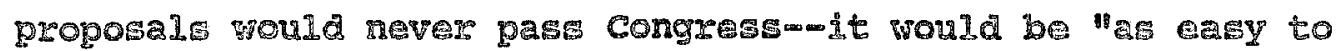
briำ a worla." She mas xight. It was too lace for senator Crittender ${ }^{\circ}$ proposale to re-escablish the rissouri

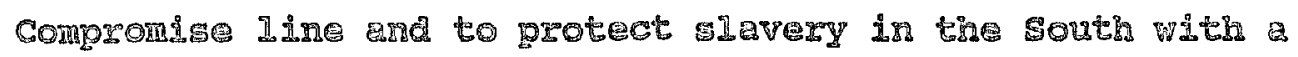
constitutional amendment. 14

The continued secession wi states Missjssipgi on January 2. F10rdda os January 10, and Alabama on January 13) "rhe manes: of those polítical metaphysician, anc aristocratic southern yrats had so angered wortherners greviousy sympthetic to the South, thought carroli, that

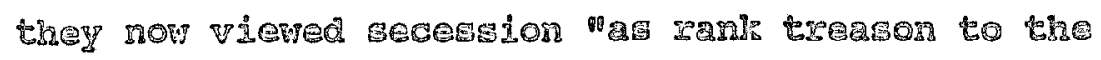


government, and believe it is the planned work of traitors. As do I." In spite of her many friends among southern politicians, "I love my country . . far more," and she would not support her friends in such a cause as secession. She could see "nothing for the Border states to do, but to adhere to their owrs conservative principles and bow to the supremey of constitutional law. Iincoin is the Lawful President of the Nation. . . 15

Hicls continued to buy time for anti-secession sentiment. He appointed seven Marylanders as commissioners to the February Peace Convention in Washington. ${ }^{16}$ AII, however, with the exception of attorney Reverdy Johnson, were notable for their mediocrity. Johnson, moreover, proposed a resolution that while sesession was deplorable, coercing "in any form the said states to reunion or subrigsion" was just as deplorable, and the goverment should abstain from such coercion as it would lead to an "irreparable breach and . . to incalculable ills."The Convention ad not vote or his resolution. 17 The question of compion raisea by Johnson was one carroll had not yet seteled in her ow mind. She was inclined to think the RepubIICans as a mole mere against it, since their 1860 party platforn had had a plank muportang states rights. Yet 0 if theme Southern desperadoss are in earmest, in impeding the comerce of the Great Horth West, the carnage wi1 be terribled teromide. 18 
of more immediate importance to carroll by the close of January was her safety. Was she safe in Washington? she sought reassurance from Hicks. She was rooming at the Washington House in the city and was "the only Southerner in the whole establishment. The ladies flocis to my parlor, for news and rely far more on me, than on theix husbands for infomation \& knowledge of southern intentions. Ieading secessionists who called to make farewell visits to me, gave me the earnest assurance that it was no part of the southern programme to attack this city..." If she left prior to Inauguration Day, not onIy would it be pexsonally inconvenient to her as it inierfered with her work, but also It would be the immediate signal of every Northem lady's leaving--supposing it be done from apprehension of danger." Ficls apparentIy assured ler of hex safety, for not only did she stay in the city, but she wrote to a New York newspaper to express her certainty the city would not be attacked, that ". . We are in possssion of such facts as to autrorize us to pubisin an unecuivocal denial to the report of [\$ecensionists ] intended attempt to seize the Capital . . . no such design is contemplated . . .19

Fer state safe, 1 person sate, Carroll next looked to ner constant concern: patronage. The fact that CarrolI thonght she deserved attention and employnent for her friend and family from the Incoming Republicans, after she hed falled to mppont Limcoln in the election exemplifies 
Carroll's tendency to view her abilities, actions, and influence in whatever form that could get her what she wanted. Obssessed with a desire for power, attention, recognition, and reward, she constantly reinterpreted her own actions and misinterpreted the actions of others until she arrived at a conclusion which served to fulfill hex needs, however far from reality that condusion might be. Carrol's attempt: to presume upon her acquaintance with Thurlow weed is a prime example of this characteristic. There exIsts no avidence that weed mas particularly close, professiona11y or personally, to Carrol1. In her letters, though, she demanded favors of him that few people not well acguahintad with the Regublican leader would even suggest. weed"s position as a medatoto beween the seward faction and IIำoln made hIm a prime target for carroll's weries. She begar soon after the election, Dressing Weed to have John Minor Botts put in the cabinet, along with Jonn A cilmex, a

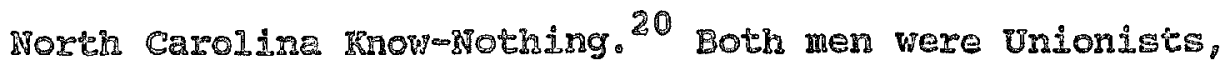
both knev Garoll well, and both would undoubtedy feel obIjgated to help her with patronage positions in the Iuture. Both Botts and filmer were under serious consideration by Incon on Feed ${ }^{\circ}$ advice. Though thexe is nothing to indicate ther were suggested by mead at carroII's Instigation, sise mould no doubt claim the crodic is ejther man were chosen. wheoln setted on GImer as the best cholce anong tre southern and Border State Unionistg. 
Gilmer met an offer of a Cabinet position with a demand that Lincoln publicly declare his intention that the new administration would back down from its opposition to slavery in the territories. Iincoln refused, and Gilmer zegretfully decined the tentative offer. 21

Carroll had urged that cilmer end Botts both be put in the cabinet to draw on Unionist support in North Carolina and virginia. Failure to include either onemor any Southern man-mangered carroll greatly, and she did not Jnow or lgnored that the southerners selected had refused office on Iincoln ${ }^{\circ}$ g terms. ${ }^{22}$ she later wrote that Iincoln's actions constituted "an irxeparable blundex" by "Constructing his cabinet on partisan grounds. Fe was intent alone In hamonding the radical and conservative alement: of nis party. It was fatal exror not to have taken - - mome one, or nore, representing, not party, brt the Union Eentiment of the South." For Carroll, the crisis Bo the country was great enough that party interests should be put așde. She redd the dispoportonate reprasentation of Northemere in the cablnet rasponsible for increasing mhe ponar of the rebe1IIon a mundred fold! 23

By parch, carrold turned to more personal concerns in her correspondence with weed, asping hira to wse his infunence with Lincoln for an appointment for her facher to the Naval orfice In Beltimore. He had held the orfice before, and "here was nevar a more saithind, erficient \& 
valuable officer than he." She wanted Weed to write to Seward in support of her petition for her father's job: "I want it done as a recognition of my claims \& without solicitation. 124 what claim she thought she had is unclear. Feed apparently made no effort to fulfill her request, and carroll zesentwliy concluded that he did not "mean to try and aid me... I thought it would have given you pleasure. . . she had been ill and aid not mant to have to go to see Iincoln herself, but "I suppose with a hurdred fxienda I mald have to do this myself. It is mrong, that I should be obliged to vee him... It is due to me that my Father be terciered the Naval office. ${ }^{22}$ When Weed Ealed her, she tumed to Botts, who saluted her

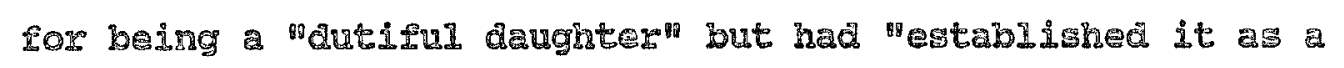

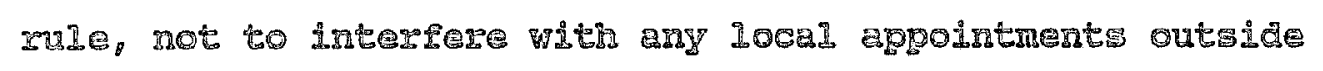
my own State. 26

Convirised that Weat possessed considerable control over patronage, carroll coninued to badger him with recresta, as fridends bagered her: John Iry wanted her to seve a Regrementative Thomes Corwin, Caroll wrole wed, was too III to accegt his appointment as Minister to mexico, but she conId provide the peregt substitute in Iemel Dale Evans, a

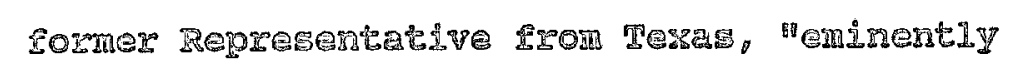
gualified - - really a great man in drtellect. Prans must have been a very close iriend, beserse "if he gets it," 
Carroll wrote, "I will go with him... ."28 carroll hung onto the Idea of Evans as an ambassador tenaciously. Corwin accepted his nomination, so she proposed Evans for a post in Constantinople, writing to secretary of state william Seward's son, Frederidy, and then making the same proposal to Weed. 29

In the midst of this constant and continuing struggle for patronage, in which Carroll nad ro reasonable hope of success, the secession crisis in Maryland came to the forefront again. The war had begus in Apri, and the tzansportation of United states troops through Maryland to protect the Gity of Washington sparked protestr from Marylanders. A 210t on Apris 39 in Baltimore ageinst the 6th Massmchusetts kegiment wes comdemned by both Iincoin and Carrold. "Our men are not noles, and can to ander the earts: they are not birds and cant Ely through the air. There 15 so way but to march across, and that they met

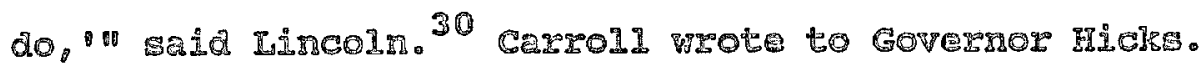
Indignast at the "aisgraceful and atrocions outrages in Baltimore, " she warned thet miess Hicls could make it alear the dty had ben in momentary control of the seccessionists during the ziot, a "terrible retribution" would be visited upon it. It ma imperetve that Hicks mantain his Unionist stance, and that meant the sederal troops must be guaranteed sare passage. "qua cambl dany the right of trandt to the Morthern troope through the torrtery of Maxyland, called by 
the President to defend their capital and your own," Carroll wrote.

Maryland thank God is still a state of chis union. It is the sworn duty of Mr. Iincoln to defend the seat of government--the trcops can approach it only over the soli of Maryland and what power have you to prohibit their approach? That Maryland ceded to the United states a national seat of government and then withide the right of peaceful transit over her highways essential to malse it safe and suitable for the purposes for which it was ceded, or to defend it in time of war, is so glaringIy absurd as to shock the common sense of any one. And such a declaration would be [meormed] by the cividized world.

For you to pretend to say, that the trooops shall not pass through the territory of Maryland would be a virtual abanconment of your whole former position and your gublic declaratign of your adisesion to the Southern confederacy.

Hidss had had to make one concession to case tension In his gtate: he had called for a special legislative

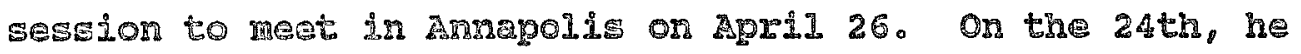
moved the meeting place to the more peaceable and strongly UnLonige aty of Trederick in western haryland. carroll Fanted to go to Frederick to use her infuence. . to stop their madnos: 2 the disudon movenert, but passage to Annapolis or to Frederids conz not be guaranteed. "50 I ard Flooding the Legislators, Heaven defend us from such, vith letters. I WIII be heard there \& if the miserable fools pass the ordinance [of mecession], let them go : surfer the consequences." 32 The legislature did not pass ar ordinance it voted on April 27 that it did not even have the rught to congder secession, and in early 
May, voted that it would not call a convention that could grant it that power. ${ }^{33}$ By May 13, troops under command of Major General Benjamin $F$. Butler occupied the city of Baltimore. Control over the state by unionists was at last realized. Hichs had held out successfully, and carroll coula breathe a sigh of relie: that her state would remain 10Yal to the united states. 34

In her letter to Hicks after the Baltimore riots, carroll had begn to articulate her vîew of the nature of the rebelion against the federal government. By the summer of 1861, Ghe vas ready to distribute her arguments in support of the President': policies to the country at largo. From July 1861 until May 1862 , she wrote at least four pamphots and $n$ doubt countess letters to the press to aำseminate her opirions of the legality of the war. Is those mithngs, in those troublesome times, Carroll ignored the fact she was a woman I.2 a man's world. She nade no apology for her intrusion into the political arent, as she had done in her 1856 election books and pamplets. Pexhaps she had seen enough women working for the war effort to lnow her apologies were no longer necessary. Her object was to save the Union: all else bexide was froppry. She went straight to the point In ners writing, wasting no time on decorating her arguments with the jadea of republican motherhood or wecogniming the Iinits of the cut of domesticity. IP hes arguments did not help win the fight, 
there would be no republic to be mother in, and domesticity would continue to be sadly disturbed. After the crisis, she could return to the style of her antebellum writings, but for the present, the Union was all that mattered to carroli. She would not weaken her arguments by making distracting references to her sex.

After che excitement of the spring, carroll had gone home in the eariy sumner of 1861 to her fathex's house in Church Creeg, Marylan, to be treated by mer brother, Dr. Thomes carroll, for an eye problom. 35 There she rested ara read and wrote. on JuIy is, whe wrote a letter to Edward Everett that was published ir Iiving Age. In Iesponse to Pverett' InIy 4 oration at the Academy of Husic in New York city. 36 Invert had set ont to define the purpose or the war, "the justice of the cause, and the fallaciousness of the arguments emoloyed by the south to rupgort lts actions. $3 \%$

Everett held that the Union was not a compet betreen states, that the constitution was entered into "by

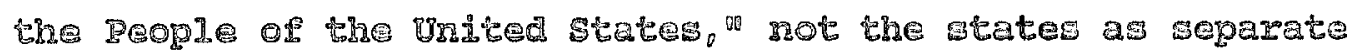
entities. To use the genrar. reservation of powers not granted to congras as given to the atates to imply a right

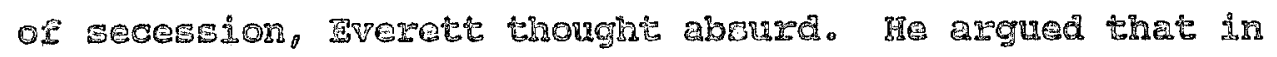

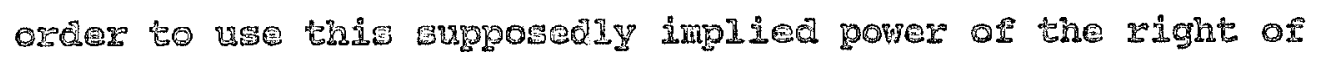

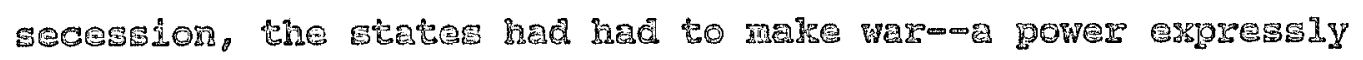
2.ำted to bise netional government. 38 using coercion to 
re-estaolish the Union as it had been was necessary, Everett argued, since "within the sphere of its delegated powers, the General Govermment deals with the individual citizen." If coercion was necessary to enforce the laws of the Union, so be $1 t^{39}$

The resumption of 5overeich powerw by the people of a stase fan argument virginia used in her ordinance of secession was invalid as weII, declared trerett. The argunent, used by John c. Calhoun in 1830 in the midst of the growing controversy over mulitication, had been rejected by James Madison that same year bacause the resumption of sovereign power could be made only by the people of tine whole united states, not by draividual states. Brotest, repeal and amencment were the oniy Iegitimate ways

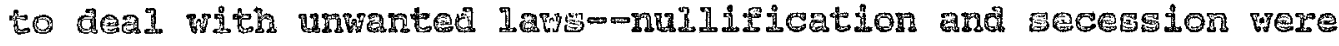
out of the realm of legal possibilities. calinoun, the patron saint af these two latter Ldeas, hed not dealt with Madison" argments against the idea of nuIlHication said gverett. But the aisedples of canour had " master." CaInoun had never really promoted accssion as a right. only one santence $2 \pi$ his Discourse on the Constitution claimed ho right of a state to secede from the

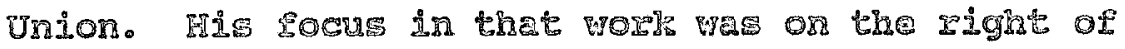
nuIIfication. CaIhoun maintained the roght of revolution. but in the south vere revolting, argued Everett, the causes bhey had given were not enough to justify that 


\section{revolution. 40}

\section{Everett's comments on Calhoun caught Carroll's} attention. Everett had supported his contention that Calhoun had not maintained the right of secession with a Ietter by Maryland lawyer Reverdy Johnson appenced to his address. Jomnon hae boarded in the same house as calhoun during two sessions of congress and had talked with him orter. cancun, mald Johnson, had placed secession on the same ground as pevolution. Both wonld destroy the governat, "and so Constitution, the rork of sane men, ever

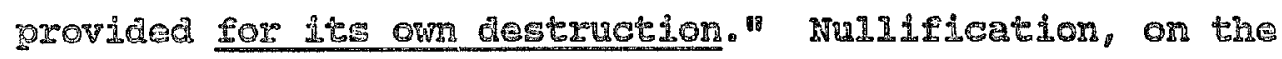
other hand, was meant to preserve the constitution "prastida11y, but to amend it, and in a constitutional mode. ${ }^{21}$

Reverdy Johnson was Wrong, wrote Carall. While "uncuestionably a genteran of profound legal

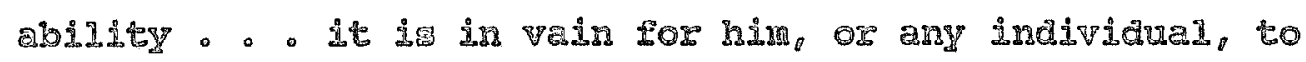

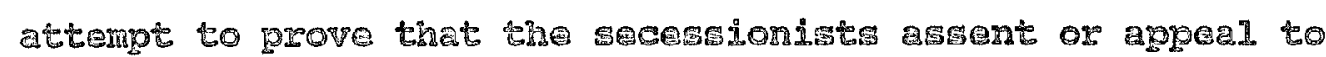
ary other prangaple now then that wing calnour enunciated . - dissenineting which he spert the labor of his crtice Iite, and runea two generations of southern men, who have been edrcated to beldeve it.

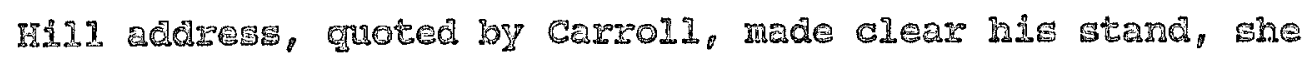

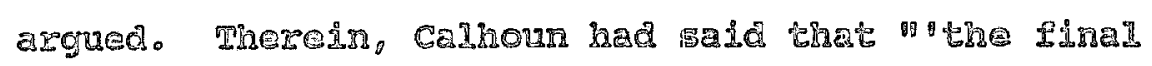
cognimance or a gustion or contested power wowld be in the states and not In the Graren Government. ต 
nullification was the arrest of one or more federal acts by the state, and secession the arrest of all federal actis by the state, it was impossible for any mind to distinguish between secession and nullification. ${ }^{43}$ Both doctrines meant that states could not be coerced into following federal laws, and both were insupportable it the onjted States was to survive as a federal government. Feving blamed the war on Calhoun and his followers, Carrold moved next to desend the President' ${ }^{\prime}$ war neasures. She returned to washington in the hat and humidity of mid-JuIy, where she read senator John c. Breckinxidge's speech opposing a resolution to approve Iincoin's actions in the 邽ashington papers. 44 on August 7, Breckinridge had gone to Baltimore where he asserted before a large arowd that the state of Maryland had been abolighed, a military alctatorship hat been established, ard bine pople of Mary lana shoula prepare to revolt. 45

John Brakinxidge had been VICE-President under Buchanas, Senator from Rentuchy, and the Southern Democrats" Fresidental nominee. He mas also the sephan of the

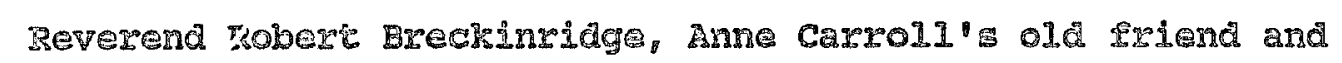
minister. With deep pain, carroll had watched nim as he voted againgt I2mCoLs"S poljGLes in the eary days of the war and gave speeches mor the purpose of stimlating and

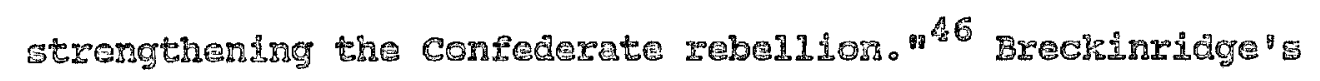
opposition stenmed from his belier that the President had 
taken upon himself powers he did not possess. He had established a blockade, made war on the South, called for enlistments, and suspended the writ of habeas corpus, all powers which Breckinridge thought the constitution had granted to congress, rather than to the Executive. The government could "esercise such powers and such only as" were given in this witten fom of government... . If the power: be not sufficient, still none others were granted and none others can be exercised." 47 In a pamphlet entitied Reply to Breckinridge, Carroll stated that the whole argument of whether or not the President had acted legally turned on the guestion of "whether the overt act of treason, which the constitution defines to be levying war against the United states, had been comitted? Whether the confederate states of the Solth commenced the war? ${ }^{48}$ or ald the President make war upon the South?

When consdoring the accusations against the President, Carrol wanted the reader to feep the source of trose accusations in mind. The first few pages of her short pamphlet were thu devoted to whowing the decede-1ong conspilgay of Southerners, begun at the rashville convention 2n 1850. to secede from the United states and form a

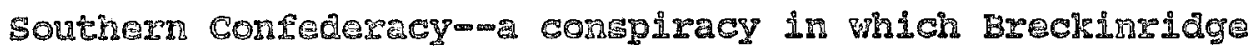
toos part.

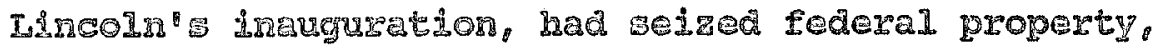

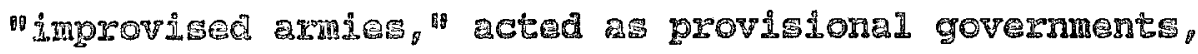


recruited soldiers to fight, "stormed Fort sumter, and put in motion a formidable army for the capture of Washington and the overthrow of the covernment." 50 The President's actions in meeting these threats to the nation were thus defensive by their very nature, for they were designed to defend the country against attak, to prevent the "gubversion of the coverment," and to ensure the national expdistence. 51

Granted the premise that the South and not the President made the war. Carroll's next task was to consider the duties of the Execueive In such a position. The Constitution provided that Iincoln should "faitufully execute the Iars." Wile he was not given the power to declare wax, he could, given che absence of a sitting congress, ". - delend the assault on the nation's life: because his right rests on the supreme or universal lav of gaIf-deresse, comon to nations as to individuals." As the defender of the Iife of the ration, he was expresily granted powers as comander-1n-chief, Carroll argued, and that "express grant of wax-conducting power . . cars the implied power to use every belligerent right know to che law or war.

carpol interpreted the war as an insurrection becars: whe thoughe that interpretation would not grant the Confeceracy beligerent status as an independent nation. Thus the power of mar monle stay in the Dresident' hands as 
a defender and executor of the national laws, rather than be put into congressionaI hands as the body to declare war against a foreign nation. This interpretation meant that all the actions that followed: the blockade, the call for volunteers, ever the suspension of the writ of habeas corpus were mereIy means (expressly and constitutionaly granted) to the end of defending the union and the constitution. 53 While Carrol's overall Interpretation of the Pregident" war powers coincided with the administration, she was confronted with the same dilemma that faced all Union propagandists seeiring to support Iincoln's war measures. Incoln's actions as the chief esecutive coula not be legaliy reconclied witin his actions as commanderin-chief. If he were acting as an exentive officer and controling an Insurrection, for instance, he had no legal zight to institute a blockade of Southen ports. A bIockade mas an act of mar, and mas asisted betwern two beligerents, not between the aivil government

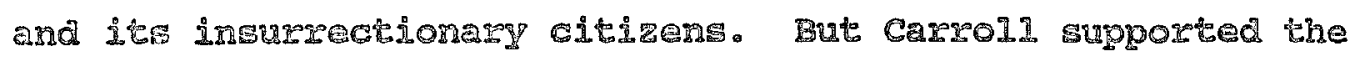
Presidext' actons by arguing that his status as

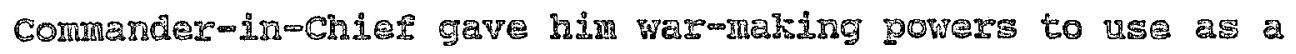
Law-enforcer, and that any power nomelly used in wax was

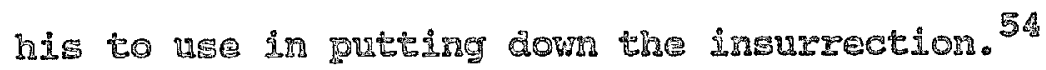

In the IOng Im, Grral was forcad to fall back to the mane position thet Iincoln occupted when his actions

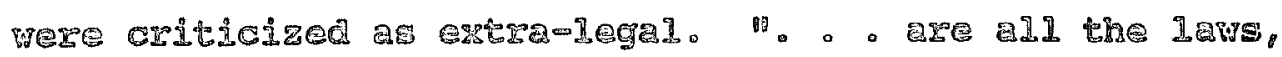


but one, to go unexecuted," Iincoln asked of congress on July 4, 1861, "and the government itself go to pieces, lest that one be violated?" Iincoln's answer was no, and so was carroli's. The extraorainary danger to the survival of the union itself outweighed the temporary suspension of specific 1 aws. 55

In her Reply, Carroli's statement that Iincoln's war-powers carried "the implied power to use every belligerent right mown to the Iaw of war" served to weaken her argument. With her careless choice of legal vocabulary, whe seemed to be saying that the federal government should view the confederates as belligerents. If the confederates were formally recognized as belligerents, however, the

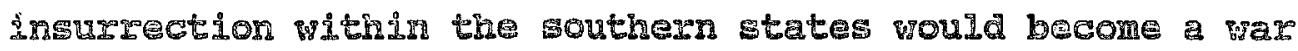
between two national governments. 56 The aministration would never make enis legal aistinction and, in Eact, went through extroordinary manipulations of vocabulary to ensure the Aintinction was not made. Periaps what Carroll meant when she referred to belligerent rights was what happened during the war. While the United States never Pomaly recognized the confederacy as a beligerent, the federal government conceded Lt beligerent rightø. Captured confederate crens were hald as prisoners of war for mampIe, zother then as pirates. Confederete officers and soldierm were regarded as a rebel arm, not a motley group of trattors. The iniserent contradicton betwen the IageI 
theory and the practice of war, however, remained a controversial issue. 57

Proclaining Iuincoln's war measures as defensive in nature, Carroll did not hold IIncoln responsible for sterting the war. She did view his decision to stand fim with his party's position regarding teriatorial slavery as the precipitate cause of secession, however. But though his decision was critiaized by paciftsts, Unionists fincludirg Carroll hergelif, Southerners and historians, the promsecession conspirators had done everything they could. carrol1 azgued, to ensure that no compromise on the issue of slavery would pass congress. They wanted ont of the Union, and they had fixed the first shot. The way was their choice, she wrote, and in making war, Iincols was marely defending the country and exerding his constitutional authority to put down the "heretican" doctrine that the governumi could not coerce a state to obey federal 2.89 58

Fhe last Eection of Carrol ${ }^{\circ}$ pamplet defenced the

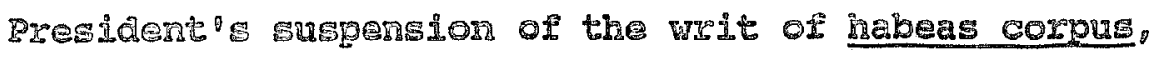
aroiteray arrests, and the suppression of the press. This last charge gave carroll particular pause, for "as an independent member or the press I will never consent to see its porer trameled or its freedom abriaged by Presicient or ruler." ${ }^{59}$ But the press (in this case a pro-conrederate St. Louis paper) bad been used by confederates to trample 
the very institutions it was supposed to defend by calling for their destruction through the destruction of the United states. Therefore, argued carroll, that press should be shut down. Here again, the temporary suspension of various constitutional rights, if necescary to preserve the whole Constitution, was the proper course of action for the President, as commander-In-Chier, to take. Martial law transcended aivil law when it was imposed for the preservation of that Givil Iaw. 60

Carro1 ${ }^{\circ}$ Seply to Breckinridge was well received. Samel T. wlilians, attorney for the Congressional Globe, wrote that he we arre that 8 if spoker in the senate, your article would have been regarded by the cengtry as a complete and masterly refutation of pro. B's heresies."61 She sent copies of it to calob Smith secretary of the Interior, and to Attorney General Bates, who also passed along copy ase Ieft for the President. 62 she printed some 10,000 copies for aistribution bhroughout the Border States, primarily as hes om daea, but also as a way to convince the

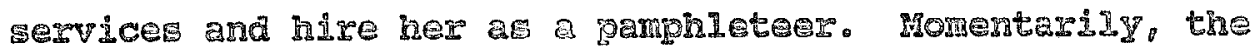
tactic worged. On October 2, I861, she met with assistant Secretry of mar Thomas A. Scott, hino led her to undergtand

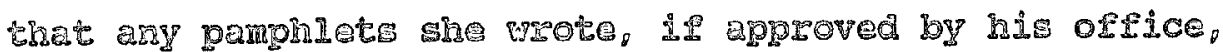
could be biled to the mar Departmenc for printing and 12bos.63 


\section{Carroll continued to defend most of Lincoln's}

actions. In september, she had issued a short pamphlet supporting Attorney General Bates' defense of the President's actions; in December 1861, she issued The War Powers of the General Government. 64 Her primary argument therein was, once again, that the actions the President took such as suspending the writ of habeas corpus or majing arbitrary arrests were legal, as long as they were taken to Fulf11 his Iunetion as President, executor of the laws of the land, and commander-in-chief. But carroll also used this pamphlet to argue against the confiscation and subseguent emancipation of slaves.

carroll had feared Iincolns's" "abolitionist tendencies" fron the beginning. By August of $1861_{8}$ she was sure he was bent on destroying slavery as the confiscation Act of 186. became law. Samel Williams had tried to arsuage her fears: if Iincoln were an abolitionist, he wrote, he would, as WIIIam L1oya Garrison and wendell pirling had done, rejoice "over the secession of the South, because they believe with good reason, that separation dooms slavery by renoving it from the protection of Federal Iaw. Incoln, therefore, if he favored abolition, would, if ne acted consistently, end the war." ${ }^{65}$ caxpoll may have believed this argment; after all, she had writen Jefierson Davis, with whom she พres wamly aceruanted, on the occesion of his inauguration, that it you 
continue . . war will result. Slavery will perish, for the nations of the earth, however they may hate republican government, cannot in this age of the world aid or abet it on this continent. "66 carroll hated slavery, and she was sure it would eventually disappear, but she believed that the federal goverment could not legally interfere with the institution. If slavery were to die, it would be a natural death, not an execution.

In the rough draft of The war Powers, carroll wrote of one correspondent who had described Iincoln to her as an abolitionist, "a renegade southerner, narrow minded, as all ignorant men are, [who] nates the south intensely, because he did not get its votes." Carroll feared that hatred would end the possibility of restorlng the union with slavery Lntact, a condition which she deexed essential to preserve the Southers economy and rociety. Indncoln mut recognize kn South as part of the "great family of the Nation, in spite of lts peandar InEtitution and he must regpet the

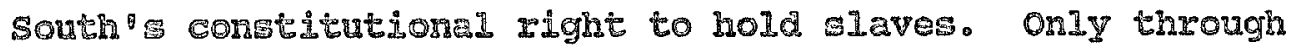
che eftorts of "alldes on the sol' of $^{11}$ the south, Carroll held, could the North hope to restore the union. But "while [Lincoln] acts exalusively on his anti-alavery prejudices" " by threatening amcipation through auch acts as Contiscation, "the American people may abandon at once al peasonable hope or expectation or nl: ading the war. It cannot be done. ${ }^{86} 67$ 
Carroll interpreted the government's confiscation policy as the first step toward forced emancipation. It was not. It was a way to weaken the enemy by depriving him of money and materiel. The August 1861 act provided for the condemnation and seizure of all property used to aid the rebeliton. Such property of course included slaves, some of whom ha helped buila confederate batteries. ${ }^{68}$ while confiscation may have been militarily sound and politic measure, it was legally questionable, and was rarely enforead. 69 still, Carroll viewed the act as an opportunity for the presidert to emancipate slaves and held Iincoln pexsonal.1y responsible for enforcing an unconstitutional 1aw。

At one point in her rough araft of The war Powers. carroll even called for the romoval of "every obstruction" that stood in the way of pursuing the war to its constgitutonal end (i.e. preserving the Union) "even if it be a Eresident of the United stater ${ }^{70}$ But by the time she finished ner pamphlet, her rhetoric had become less impassioned and more legalistic. Since the war was being waged to preserve the constitution, whe wrote, "the war power itself must not trample that instrument in the dust. ${ }^{72}$

The discussion of a second confiscation act had begun with the promined introducton of a bil by senator Iymen Truwo 11 on December 2, 1861. Carrold viemed such 
bill as one of many "wild theories" being proposed and argued that all acts that suggested the government could confiscate all the property of the rebels, both private and public, were inherently unconstitutional. The United states wanted to regard the war as an insurrection rather than a war between two independent powers. It could not. thexefore, abrogate the Constitution that it said was still in place within the areas in rebelion. In other words, to leep the war a rebelizon required a constitutional conquct of els war. The constitution was still the law of the land In the south, according to the North: therefore, it should not be trampled upon in order to preserve it. The Congtitution forbade taking private property for public use without just compensation. Since "the covernment car gain no new powers, by putting dom the rebellion," it had not, by virtue of the waz, gained the powex to confiacate property without due process of law. If the government proposed to confiscate property under the laws of was, it Hould be admitting the confederay was a ration, the vary thing it wanted to avoid. carroll was willing to jettison Constitutional gumrantees to such privileges as the writ of habeas corpus to preserve the union: she was not willing to do so to iree slaves. Although she had bean able to maintein an argument that achnomiadged Iincoln condake actions of war whic acting as an executive in her aerder

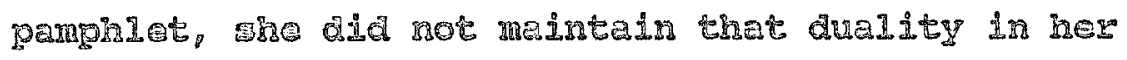


interpretation of any confiscation act. Carroll saw beyond the attempt's stated purpose of confiscation and included its effect of freeing slaves as the basis of her criticism. 72

one of carrol1's primary aims in The War Powers was to convince her readers, especially those in congress, of the "utter Impossibility" that the war could emancipate slaves in the south. The "fanatios" that desired it did not understand that the policy of abolition "can never hope to restore the union, while it would be sheer auicide to the Constitution. Such a policy might create unity, which is a very different thing from union: but it would be the unity of a frigntiul despotign over both the South and North."73 For Carrol1, the way to emancipate was not by force or decree, but by "preservation of the union, and with that silent progress of inteligence and virtue which the union alone can guarante. "74 The War powers was printed and distributed to all the members of congress. 75

Carrol1's parplot did not end the question as she probably hoped it world. There can bo no doubt thet carroll desplsed Bdavery. Hex work to buy her father slaves prior to the war, freeing her ow slaves, her mupport for colonization were evidence of her hatred for the institution. But she was Irengy aware of the psychological, sociological, and economid upheaval that would result in the South if glaves were freed without compensation. 
colonization, or due process of law. Events in the spring of 1862, however, made it clear to Carroll that the push for emancipation had not been stalled by her writings or by her constitutional arguments. on March 13, 1862, Congress forbade the use of the military to return fugitive slaves ho had escaped into union Iines. In April, a bill for the abolition of slavery in the District of Columbia passed congress. It provided for the compensation of owners, but nevertheleas prompted carroll to write to the President. ${ }^{76}$ Unopposed to the "abstract question of abolition with colonization" she still thought he should veto the proposed bi11. She feared dt was the wrong time: the bill would aliemate all the union men in the south, since they movid see "that the abolitionists have now the control of the government, and that emancipation In the District was "the first dr the series fOr the destruction of slavery in the south - . " c. CaIhoun in 2849: once abolitionigts obtained control of the govermat, "they would proseed, first to abolish

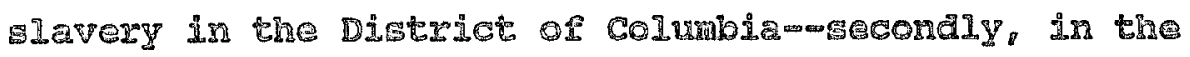
territordeswrisindy, in all the forts, magazines, arsenals, doogyarag, otc.--fourthy, to pronibit the internal slave

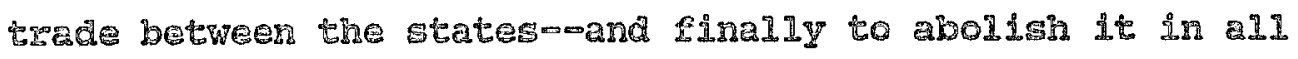
the States." Sorthern UnIonists believed calnoun had been mistajen in his assugtion thet the abolitionists would one

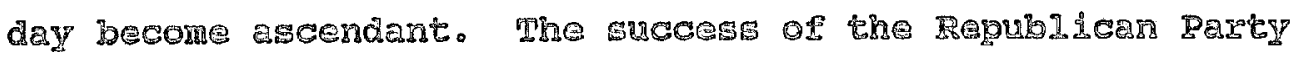


had not meant "the Abolition reign had commenced," Carroll argued: any change in the raison d'etre for the war now would change that perception. "Be not deceived, Irr. President, because the Union men of the South sustain you, in your efforts to suppress the rebelilon and maintain the integrity of the constitution, that they wi1 ever submit to the abolition of slavery, by the [general] goverment." If the President signed the bill, the war would is protracted "gor month, it may be, for year, " and the rebels would gain "a reinforcement of at least fifty thousand fighting mer" from Border states opposed to any form of mancipation. "1500 Africans" might be freed as a result of the measure, but "you consign to a bloody grave, at Ieast tan thousand patriot woldiex. Fven if congress passea the biIl over his veto, at leat Inncoln'g hands พould be cleas as far as abolition was concerned. That was bre Important point for carrond: the President must not be the one to change the nature of the war. 77

Inincoln signed the bill and returned it to congress on April 16, never coubting "the constitutiona authority or congress to abolish slavery in this District" and having "ever desired to see the national capital freed from the institution in some satigractory way" since the bill provided Bor compenseted mancipation with the possibility

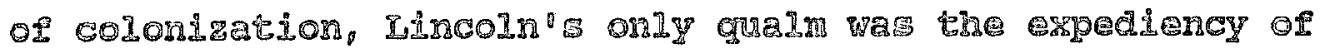

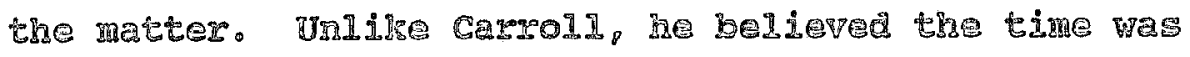


right. ${ }^{78}$

Carroll must have been disappointed that she had failed to stop Iincoln from signing the bill, but there was a note on her copy of her letter to hin that he had not received it prior to signing the measure, which no doubt comforted her. However, she was destined to be disappointed again over the issue of confiscation, which came up in May in debates over a second confiscation act. one version of the bi11 came before the senate in the spring of 1862 . on May 19, Senator Char Ies Sumer of Massachusetts rose to argue for its passage to suppress the insurrection, to punish treason, and rebelion, to selze and confiscate the property of the rebels ..." sumner's arguments in support of the bill led to carrol1' pamphlet defining the Relation of the National Governent to the Revolted citizens. 79

Sumner axgued that the peculiar nature of this civil war had placed the south in a cort of dowble jeopardy. They were criminals, guilty of treason: they were enenies because they had made war against the united states. Consequenty, "we are at Iiberty to... treat the people angaged against us as criminals or as enemies, or, if we please, as both."180 Criminals, as traitors, woula be subject to the constitutional proviaions which ordered that "Congress she11 have Dowex to declare the Iunishment of

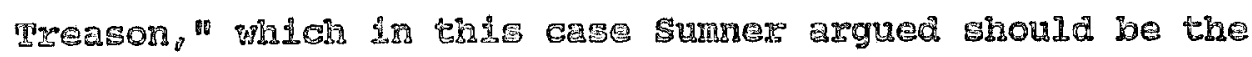


forfeiture of property, as provided in Article III, Section 3 of the Constitution. Enemies would be subject to the "rights of war" which provided that the "private property of an enemy on land may be taken as a penaity for the illegal acts of individuals, or of the community to which they belong." 81 If slaves were considered property, they could be confiscated as the and's property had traditionally been confiscated during time of war. If slaves were humans, they existed in a "constant state of war" with their masters anyway, by virtue of the institution which enslaved them. Thus, in freeing them, the united states was simply taking "advantage of the actual condition of things. 82

If confederates vere criminals, Sumner continued, it was the duty of the rorth to "pursue and punish then"; if they were enemies, it was the duty of the united states to oblast ther with that sumary vengeance which is among the dread agencies of war . . . "83 Freedom for slaves would "take from the rebel1Lon jts mainspring of activity and strength . . its chief source of provisions and supplies . . a motive and temptation to prolonged resistance, and you will destroy forever that disturbing influence which, so long as it is allowed to exist, will seep fhls land a polcano ever ready to breas forth anev! "98 8

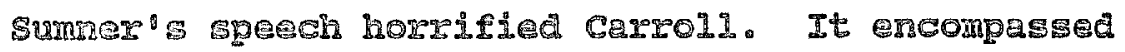
aI1 she sad been sighting against: abolition, disunion, and 
revenge. In a letter to Lincoln, she was even willing to move away from her earlier position that the war was an insurrection. The "go called southern confederacy, is now to this government, as a foreign power and people are as much under the dominion of a forelgn yoke as though the Stater were held by france, or Great Britain, instead of domestic foes $_{f}$ "she vrote. "Davis has coerced the obedience and submission of the entire population, and recognition of the United states as the झupiene power by any southerner wovld be "at the peris of his life." If the rebellion had İ Eact succeded in establinhing a foreign goverment, Carrol argud, the "the rules and regulations" of public law "apply in all their force... " Confiscated property Moula return to its owers, under the rules of international

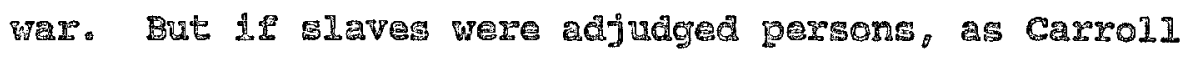
believed they were, they could not "under the constitution be deprived of their Iiberty" confiscation, because it wossla lead to emandpation, meant trouble. It also meant expense, sinee the omers mould have to be compensated for thedr property chat was not returned to then and get had not been "sold, transeryed or lost by the was . . "85 The magor problen for carrol1-mand for IIncolnmagarding the second confiscation Aet was the definition or both the teatra and tive property of the

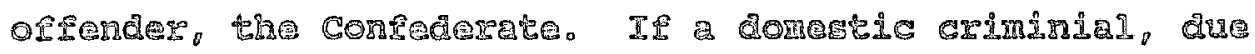
process regarding the seigrre or property had to be 
observed; if a traitor, punishment for treason could not constitutionally extend beyond the life of the traitor (i.e., could not extend to titled property). Therefore, a blanket declaration that all persons "in rebellion" against the United States should Iose their slaves posed problems under either definition. Either all traitors woula have to be tried individually, or slaves would have to be legally defined as persons, not property-which they could not be, since ther they woula not be liable to seizure. 86

Carrol sew "an express inhibition upon the power of Congress to abolish slavery or confiscate the property of rebels." The Constitution specifically defined what treason was and "absolutely inhibit[ed] the confiscation of the estate of the traitor to the goverment, leaving it ryee to pass to IIs hejrs" The confirgation Mct under consideration congress would adjudge the Southerners guilty without trial, decide their punishment phe IOss of property), and erecute that punishment (by confiscating their propertyl. (bil1 more directy in confdict with the Constitution could not have been drawn, seid Carrol1.87 Where Sentor Sumer had argued that the "geculiar circungtances" of the combination of public and private war enabled Congress to treat the South as either criminal or eneny or both, as it pleased, carroll cited the same authorities and even the same passages to argue that the prohibition against confisGation "ras hrserted In the 
Constitution only to prevent the exercise of this arbitrary power" during such a rebellion. 88 sumner used the long history of confiscation to justify its recurrence. Carroll used that same history to argue that the abuse of power through confiscation had led to the inclusion of the prohibitive clause in the constitution. The Bill of Rights had further guaranteed the security of property, reinforcing the Constitution ${ }^{\circ}$ gtand against confiscation. The second Confiscation Act came not from a longstanaing tradition, but had originated "In the worst and most malignant passions of the humar heart. . - pressed in utter contempt" of those constitutional guarantees. carroll returned to her definition of the war as a domestic rebellion-only Individualy could those convicted of a crime of treason be punished by holaing their property 1 iable for damages.89

Before Congresg can claim to exeroise this power of war over any portion of the American people: it must riret recognire the rebellion as a successom their revolution accomplished, and the Union dissolved. In short, must concede to the rebellion-what no Furopean power has ventured to do-mhat they have achieved their indegendence, and have established $\mathrm{fizm}$ and stable governent, against which it is no longer proper to war with the view of suppressing it.

For Congress to tahe that position... is to becone aIIIes of the robellion, agg ourselves traitors, lile them, to the constitution.

The war might be raging, Carroll argued, but the Union remained. Southerners were still citimens and had to

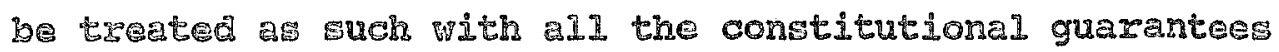
that citigenship provided. BOS5ersion of property might 
pass to the government during the war, but title to that property remained, except in the case of "movable goods," with the owner or his heirs. 91 Further, since the Southerners had been subjugated by a rebel force and the federal government was unable to protect them from that subjugation, "it cannot hold them responsible for any act they may comit while under the pressure of a usurping power." It would be difficult enough to restore arshority and geace constitutionaly: "The union of these states camrot be restored under a mutilated constitution, or under a new and alfferent one." Confiscation would continue the war "for the sake of power. For the annals of the world record no instancos where the usurpers of power have ever, voluntari1y, 1aid it down.92

Carroll called The Relation of the National Govemment to the Revolted citigens Defined her "Reply to Suraer. It too was printed and distributed in congress. Where it came in for mpecial notice by New York Republicar Representative Alesander Diven, in a specan on the confiscation matter.

A specjous argument In favor of what may be done under the war ower, by vay of confiscation, has been made 0.0 Any one who desiras to see it answered wil find thet a clever woman has done dt completely. Any chever monar conla answer it . . . She signs herself in her pamphlet Anne tlla carrol1. I commend her answer on the dostrine of the var power to those who have been soldowing that phantom and misleading bhe porle. And I commend it to another individual, a friend of mine, who gave most learned disgujsition 
on the writ of habeas corpus, and against the power of the President to imprison men. He will find that answered. I am not surprised at this. The French Revolution discovered great political minds in some of the French women, and I am happy to see in these troublous times that there is a like development in our vomen.

In addition to her arguments about the unconstitutionality of confiscation, carroll continued to campaign against the policies she thought might lead to Iorced mancipation. She wrote Iincoln that "any abolition programm, whether it be by confiscation Act, orders by Military cenerals [Fremont ' freeing slaves in Hissour: and David Hunter's May 9,1862, proclametion in North Carolina], or by arming the slaves as al1 Ies of the Governent" would strengthen Southern resolve to defeat the Inion mnti "a malion of men" woula be required to defeat the south. ${ }^{94}$ The expense alone woula ruin the country and would destroy Incolr. carroli grew exaspexated: "I camot allow rnyself to speals of men so stupid, as to suppose they can charge at once, the whole socia ideas, which have from the origin of our institutions controlled the Americar people. . [to lift] up four milions of ALican slaves, mon a plane of political and socid equalit." It was absurd, it was dangerous, and it mast be stoppea last Indin become "tine last President of the United states of Mmerica. 95

Carrol1 5uggested Iingoln sina some wey to antagond. the abolitionists In order to reaswure the Border 
states and thought he should veto the final version of the second confiscation Act. "This bill will inaugurate a new policy," she argued, "and change the whole morale of the พar."

It will no longer be regarded as a war for the maintainance [sie] of the American constitution, but as one, for the subjugation of the southern states, and the destruction of their social system. And the juagment of the civilized worla will then deciae that the south is in a just struggle for Constitutional 1.iberty; against an axbitrary and revengeful government.

Intervention by surope was sure to follow if he signed the bi11, Carroll warned, and Jefferson Davis and his "comtraitors" would become heroes while Iincoln and his Cabinet would stand "in all the future, like George the Third and the Ministry of Lord North." 96

Iincoln did have objections to the confiscation Act, and in fact broke precedent by sending his proposed veto along with the signed bill back to congress on July 17 . one of his objections vas centered on the extinguishment of real estate titles, which was an unconstitutional forteiture of pxoperty because 1t extended beyora the life of the guilty party. His second objection was also one carroll had raised in her pamphiet. As provided for in the Act, proceedings of property forteiture in rem, gather than in personam, lea to - forfejture of property "Without a conviation of the suposed crimine, or a personed hearing given him in any proceeding." While in rem proceedings were used in 
admiralty cases, Lincoln thought the second Confiscation Act shoula provide "a reasonable time . . for such parties to appear and have persoral hearings." 97

Unlike carroll, Iincoln did not object to the emancipation of slaves provided for in the second Confiscation Act. He chose to interpret the Act's provisions regarding property forfeiture as applicable to slaves, as carroll did. This irterpretation was apparently not the one congress made, since the Act provided separate sections for confiscation and emancipation, and did not mention slaves as property to be confiscated. But tincoln reasoned thet if property forfeited to the general government under the Act Included slaves, the government, "go far as there can be ownershig." owned those slaves. He then had "no objection to congress deciding in advance that they shall be iree" As for the speciric provision which declared slaves of rebels "captives of war, and. - forever free, " Incoln suggested that congress make clear the condition under mish that provision could be enforced.98

The fat chat Iincoln signed the Second confiscation Act, even with nis reservations, mace jt grite alear to Carroll that Iincoln or Congress was going to do something about emancipetion. Iincoln's desired policy for

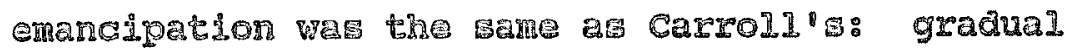
mancipetion to avola social disruption federal 
compensation to prevent economic destruction, and voluntary colonization to ensure peaceful race relations. 99 while Carroll's concern was for the preservation of the South, which made her hestitate to support any war-time emancipation measures, she remembered well the days when the slave traders came to buy those whom the plantation would no Ionger support.

I shudaer now at the sight of sueh horroxs as came before my own eyes-a daughter, clinging to her parents \& in the most delicate situation-with screans that were frantic, the whole white family of females, in tears, yet powerless to interpose . . . the most tender and devotad of mothers too far bereft by the sale of her first born boy to shed a tear. 0. Scenes like this no years have ever 100
effacedm-no time can ever make me forget.

Her antipathy toward the iastitution had led her to worp for compensated ermancipation in the 1850s. In 1861 and $1862^{\circ}$ at the same time she fought against the confiscation Acts because of their emancipatory effects, she worked to promote the colonization of freed rlaver.

BY spril of 1861, Carroll had begur working for Aaron Columbus Burx, a leading New Yoxk merchant, on a plan to colonize fred blacks in Britigh Honduras in Central America. Burx, in March of that year, had become the agent for James Grant of Belize, British Honduras, to sell Grant's 150 square miles of land in "Stand" (stann) creele, to found such a colony. Astde from what he viewed as the humanitarian motive of colonization, Grant had asired \$65,000 for the land, which ineluded considerable stands ot 
mahogany, rubber trees, "cocoa nut trees," and a

brickworks. 101

Burr had originally made a land-lease agreement with crant for a mahogany-cutting company formed in 1860. The political unrest in the area scared off investors, but Grant had received several offers for the land itseli, which Burr thought privately ought to se valued at $\$ 100,000$. Burr kept Grant from seling by promising him that he would try to sel1 it to the United states goverment. In the spring of 1861, Burr proposed to carrol1, who was, he wrote, "known as a practical advocate of colonization, that a company be formed "for the purchase of this land for the benerit of the free persons of color in the United states." Also to benefit Burr's pocket: he offered the land at what he called " "reduced price" of $\$ 75,000$, but since he had never actual1y purchased the land fron Gant, he stood to make $\$ 10,000$ on the 5ale of the land to the government, some of Which uncoubtedIy was to go to carrol. 102

Burg apparenty hired camol' as 2 lobbyist to help nim presert his case to the government. How they met and what their agreemenc was Is unciear, but by the 211 of 1661, Carroly was corresponding with Burr and apologizing that a case of cholera in dugust and september had rept her too 111 to do much work. At the wame tine, Grant was warning Burr that poacherg were gtealing mahorany and that the 1860 mahogaryocutting company was so hopelessIy 
insolvent that Burr and Grant would wind up suffering financially if steps were not taken to sell the land. Colonization of freed blacks on the land was the only way out, Grant wrote to Burr. Burr wrote to Carroll, and Carrol1 wrote to the president, proposing a colony in British Honduras. 103

Carroll presented the colony as attractively as possible. It was close to the united states, had a direct trading track by sea, easy access, a friendly goverment, a tropical climate, and fertile soil. where was an added, and perhaps overstated attraction: "the desire of the government" of British Eonduras "to develop its vast resources of wealth, by receiving upon a social and political equality, the very class of persons which it is the interest of this country to furnish." It was also a way for the United States, she wrote, "to remove the colored race and make them useful to thenselves," while still retalning them "as friends of the whites. "104 The formal proposal was finally made by Burx himself on Nay 6, 1862, to the Department of the Interior, which was In charge of all colonization projects. For $\$ 75,000$, Burr Hould transfer title, found a settement colony named the "Iincoln Colony," and "if the goverment desire Iny Bervicas" he woudd "receive these freedmen as they are transported, and wupexintend theirs location upon the land, upon whatever principle may be determined by the 
government." On May 13, Carroll wrote to secretary of the Interior Smith with a full account of the improvements on the land and included a map of scotland Town, the main settlement. The matter was laid before Lincoln by the 19th. 105

At this point, there mey have been a meeting between Carroll and Incoln regarding the colonizatios project. Reminisaing late in 1ire, Carroll recalled a touching scene in which Iincoln asged her what he should do about the matter of colonizaton.

I was perfectly charmed with his cordial and simple remarys, free from every semblance of ambition. He, in the most exalted office upon earth, deferring as bumbly to another, as is he had no potser or aim! He was patient and gentle as a woman could be, nothing brusgue about him. He got up and took a large map which he hung in the room and sat down on a small $10 \mathrm{w}$ stool by the eireplace, spread the map on his lunees. and asjsed me to point out the place I recomended for the colonization of the freedmen. I pointed to British Hondures, in Central Amarica, and gave all the reasons for this locality . . 10 to

such a domertid Bene may have been ract, or fancy areated by the passage of time and presiaential martyram. At any rate, Carrold did continue to contact Iincoln through letters, writsing to him again on May 19. In that Iong missive, she argued agairst Liberia as colory: transportatLon costs were too great, and the unwilingness of 3read blach to lave the Undted States for Afrdca was

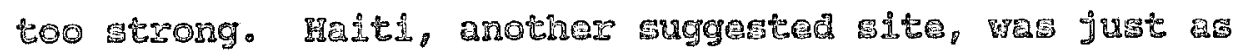
objectionable. The Is land war too mad for the "american 
element" (who were presumably used to the vastness of the North American continent and who were now four million in number). No doubt a "few, shrewd" colonists would succeed, but only by "sinking their Americanism and becoming thoroughly Furopean in their caste. . the majority . - would be held only as laborers and producers ..." In addition, the "axbitrary" government of the island would give coionists "no more chance for elevating their social and political positions than ir the United States. British Honduras was the answer. Large erough to "found an empire for many milions, it was the only country in central Americe that would not reguire civil and military support and protection from the united states for its colonists. In.se, Idberty, and propary were secure ix British Honduras, and its government mould "interpose no

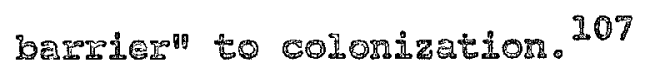

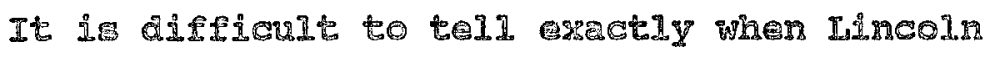
rejected the choice of Brithis Honduras as a possible

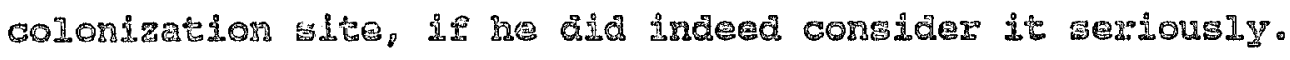
Carroll had sent him a bos of central American goodsi to convince him of the plexty that aweited colonists, ard she thought it was still alive as a cholge on August 30. She wrote to Burg telI Ing hin she was mure that the chirigui colonizeton project, arother Central Amexican site in competion mish her wugestion, was defunct. She nay not

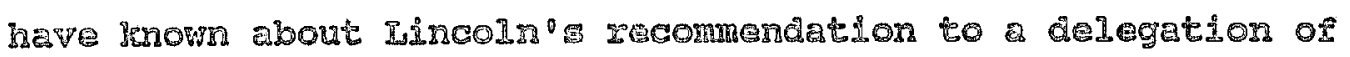


free blacks on August 14 that they go and 1.ve at Chiriqui. 108 Eut Carroll was correct in her perception that Isincoln was moving toward emancipation of slaves with or without colonization. Iincoin could see a way to accomplish emancipation either way. Much as she hated slavery, camoll could not wield such a two-edged sword. In her opinion, emancipation without coloniation would mean the loss of the Border states, and in the end, the death of the Union itself.

After a September 13 meeting with Senator Samuel c. Pomeroy, head of the stillowively chirigui project, Garrol wrote Burs that their British Honduras colonization project was dead. Instead, the "chirigui property will be bought fortunes made for the whte speculatorg through the

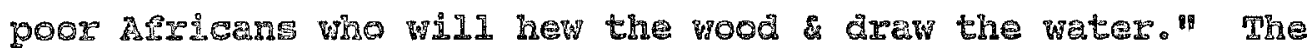
Chixigui site was not the final choice, but the administration ${ }^{\prime}$ twomponged attack on slavery continued with the issuance of the Preliminary Emancipation Prosametion on Segtenber 22. Although thic proclamation Included provisions for compensation and colonjation, the dead1ine of January I was a setback for moderation that no doubt angered carro11. or October 21 , מhe made a last-ditch 6ffort 2 : mienc of the colored" to argue once nore for the British

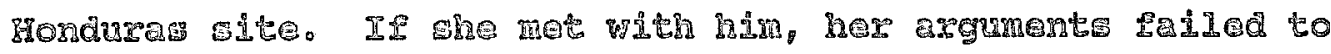

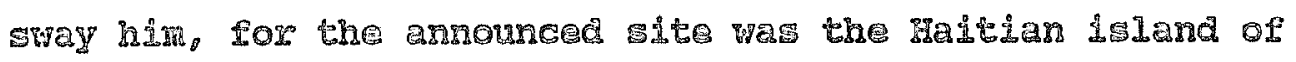


Ile A'Vache. 109

The extent to which Carroll had access to Iincoln as

well as the degree of attention he paid her ideas is difficult to ascertain. certainly he knew who she was. In August, he had thanked her for an address she had made to the people of Maryland, calling for more volunteers, which he had read "with a great deal of pleasure." certainly his Attorney General, Edward Bates, was on good terms with her and wrote to her cordially during the war. 210 while she may have occasionaliy enjoyed Iincoln's attention, she was only one of many trying to influence him. Although she did fail to convince him to follow her course of advice, carroll did articnlate soundy the concerns of the Border states regarding emancipation and colonimation. Iincoln recognized and spolse to those concerns, if not in direat reply to her. In September 1862, for example, he pointed out his fear to a visiting interdenominational delegation of christians from Chicago that "fifty thousand bayonets" from the Border States might be turnea against the union in consequence of a proposed emancipation proclamatior. This was an argunent and a figure that carrol1 bad used in her letters to Inncoln the preceding AprdI and July. ${ }^{111}$

Fragmentary evidence existo in carrol' ${ }^{\prime}$ gapers that

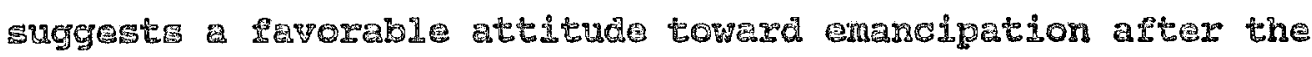
war, and orse it was a falt accompli she turned hex attention to other matters. Betwen her writings which 
supported Maryland anti-secessionists and the President's war measures, and her work on behalf of Burr for the proposed "Iincoin Colony," there was one other issue that interested carroll greatly. In the fall of 1861, Anne Carroll turned her eyes to the war in Tennessee and her hand to military strategy, thus beginning the most legendary and the most controversial action of her long career. 


\section{Notes}

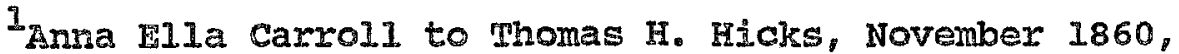
Ansa Illa Carroll Papers, Maryland Historical Society. Baltimore, Maryland.

${ }^{2}$ Morgan Dirs, son of the Conmander of the Department of Maryland John A. Dix, remarked on the importance of controling haryland for the Union, 23 July, 1861. See Charles B. Clayls, "Suppression and control of Maryland, 1861-1865: A Study in Federal-state Relations During civil Conflict, "Maryland Historical Magagine 54 (september 1959), p. 248. See 2Iso W. W. Brewer, "Lincoln and The Border States, Journal of Negro History 34 (January 1949), pp. $63=64$.

3. W. Wyne smith, "Politics and Democracy in Maryland, 1800-1854, in Maryland: A History, 1632-1974, ed. Richard Walsh and William Lloyd Foy (Beltimore: Maryland Historical Society, 1974), p. 296: Jean H. Baker, The Politics of Continuity: eraryland political Raties from 1858 to 1870 (Baltimore: Johns Hophins University Press, 1973), p. 8.

${ }^{4}$ cited in william cook wright, The secession Movement in the Madale Alente States canbury, Nen Jersey: Assocjated University Presses, $1973 \%, \mathrm{p}$. 35. Wright suggests, incorrecty, that Hicks was a secessionist at neart.

5 Gmith, "Politics and Democracy" The Politics of Contiruity p. I3.

Garer, mhe Bolitics of Continutey. P. 48.

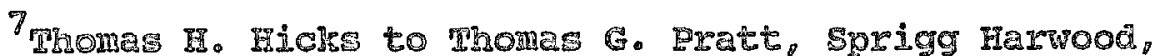
J. 5. Frankiln, ILEwellyn Boyd and I. [8] Pinkney, 27 Novemiber 1860, Covernor: E Eteterbook, Maryland state Aronives, Hell of Records, Ansapolis, Mary Iand.

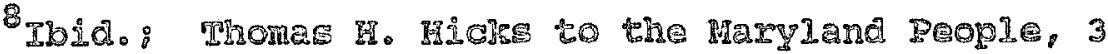
January 1861, Governor' ${ }^{\circ}$ Letterbook.

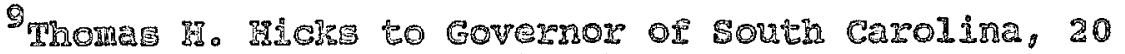
Noverbar 1860, Covermor's Lelcerbook. 
10 Thomas H. Hicks to Anna Ella Carroll, 21 December 1860, Carroll Papers; Anna Ella Carroll to Thomas H. Hicks, 16 January 1861, Carroll Papers.

${ }^{11}$ Thomas H. Hicks to Maryland People, 3 January 1861, Governor's Letterbook.

12 Anna FIIa Carroll to Thomas H. Hicks, 16 January 1861. Carroll Papers. See also W111lam J. Evitts, A Matter Of Al legíances: Maryland from 1850 to 1861 (Baltimore: Johns Hopkins university Press, 1974), pp. 164-165.

13 mhomas H. Hiars to Anna EIla Carrol1, 19 January 1861, Anna EIIa Carrol1 Papers, Carrol1, Craddock, Jensen Collection, Maryland Historical Society, Baltimore, Maryland. (Hereafter cited as CCJ Collection.]

${ }^{14}$ Although crittenden's compromise was not voted on until prarch 2 , it could be considered dead by January 16 or so, something carrol 1 in washington vas far more cognigant of than was Hicks. See Allan Nevins, The Emergence of Iincoln: Prologue to Civil War, 1859-1851 (New York: Charles Scribner' Sons, 1950), PP. 392-402: David in. Potter, Fincoln and His Barty in the Secession Grisis (How Haven, Comecticut: Yale University Press, 1942), pp. $84 \rightarrow 132$.

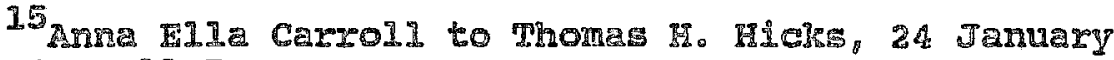
1861, Carrol1 Paperg.

16 Proceedings of the Governor, 25 January 1861 , Maryland state Mrchives, Hall of Records, Annapolis, Maryland.

17. Fo Chittenden, A Report of the Debates and Proceedings in the secret sessions of the conference Convention fox Proposing Arondments to the constiturion of the Inited States, Held at Washington, D.Co, ln Febriary, A.D. 186I (New Yoxt: D. Appleton \& C0. 2864), p. 449. See also Wright, the secession Movement, p. 52.

18 congressional Quarterly, Gujes to

U.5. Elections fhashingtor, DG: Congres: In6. 1975/. 20. 36-37\% Mna gla Carroll to Thomas IP. Eldis, 24 January 1861, Carroll papers. Carroll would later discuss the guestion of state rights against improper coercion in a letter protesting the assumpion that the General Governanent hes undimited powers even to the onitereting of state lines, and creating Provincial

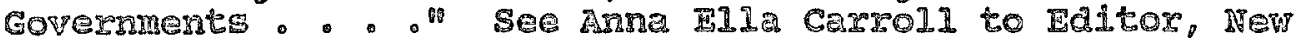


York Times, 23 March 1862.

19 Anna Ella Carroll to Thomas H. Hicks, 30 January 186I, Carroli Papers; "Independent," New York Morning Express, 31 January 1861.

20 Anna Ella Carrol1 to Thurlow Weed, 7 January 1861, Thurlow Weed Papers, Rus Rhees Library, Jniversity of Rochester, Rochester, New York.

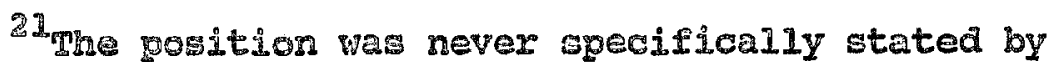
Inincoln, but was rumored to be secretary of the Navy or Postmaster-Genera1. See Daniel W. Crofts "A Reluatant Unionist: John A $_{\text {e }}$ Cilmer and Iincoln's Cabinet, "Civil war IHistory 24 (September 1978), Po. 231, 236-237, 241-242; Burton i. Hendrick, Ininco In $\mathrm{s}$ War cabinet (Boston: Littie, Brom \& CO., 1946\%, pp. 102, 114. For Iincoin's corzespondence on the matter, see Roy P. Basler, ed., The Collected Works of Abraham Lincoln, 9 vols. (Nes Brunswick, New Jersey: Rutgers University Press 1953-1955). $4: 151-153,155,164,170-171,173$.

22 [Samuel T. Willians] to anre Ella Carrollg 26 Argust 1861, Carroll Paper. Obviously, Carroll was not impressed with Ioneoln's inclusion of Missourian Fäward Bates in nis cabinet.

23 Anna PIIC Carro11, Memo on war Powers, 19 August 1861, MDHS 3650-178, p. 7 , Carroll Papers.

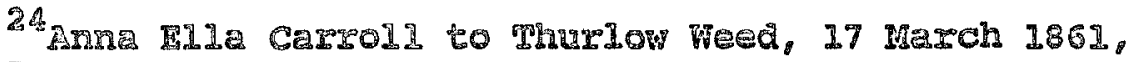
meed Paparg.

25 Anna Ella Carroll to Mhur low Weed, n.d. Weed

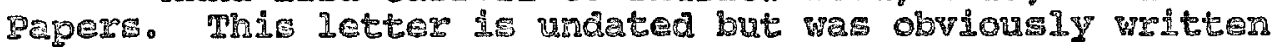
arter the 17 mareis detter.

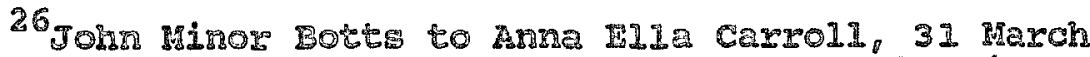
1861, Carrol1 Papers. pot surprisingly, considering hị Iefusal to help her, this is the last letter that survives fmon Botts to Carrol.

27 John B. Fry to Amna m12a Carrol1, 9 march 1861 , Carzol1 Eapers.

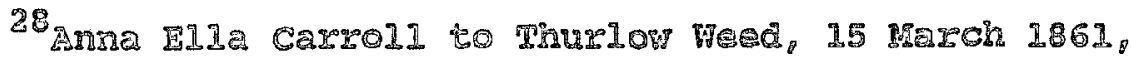
Heed Papers.

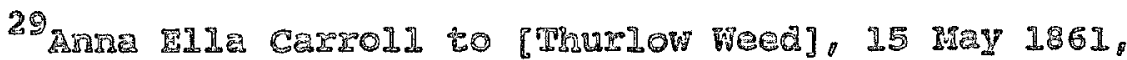
Woed Paper. The Ietter to Trederick Sewara don rot 
apparently survive.

${ }^{30}$ Abraham Iincoln in the Washington star, 22 April 1861, cited in C. Percy Powel1, Lincoln Day BY Day, A Chronology 1809-1865, 3 vols. (washington: Lincoln Sesquecentennial Commission, 1960), 3:37. See also Baker, The Politics of continuity, p. 33 .

31 Anna Ella Carroll to Thomas H. Hicks, Carroll papers, CGJ Collection.

32 Anra Fila carroll to Salmon $D$. Chase, 24 april 1861, Salmon Portland Chase Papers, Iibrary of Congress, Washington, D.C.: Anne IIIa Carrol1 to Thusiow Heed, 26 Apri1 1861, Weed Papers: Bnna Ella Carroll to Salmon P. Chase, 27 April 1861, Chase papers. Secretary of War simon cameron's ineptitude was pronounced enough that both Chase and Secretary of State Wilijam Henry Seward took part in activities normaly beyond their purview. See I. W. Schuckers, The Life and Bublic Services of Salmon Portland Chase, United States senator and Governor of ohio: Secretary of the hreasury, and chief-Justice of the united states (New York: D. Appleton \& Co., 1874), pp. 419-420, 424. Carroll appealed to chase for a safe escort to Annapolis. She may have met hin through her friesdship with Onioan Thomes Corwin, and may have chowen to approach him as we12 as Seward (through weed), since seward and weed were so unresponsive to her requests. Is far as her Ietters to icuislatorn, unfortunately, none of the delegates to the spec: al messizon appear to have preserved their papers. conse zuent Iy none of casroll's letters have apparanty \$urvivet?

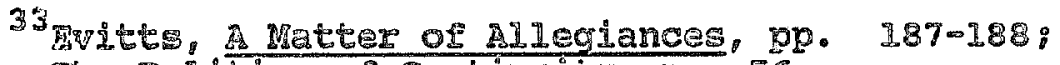
Baker, Ine Polities of Continuits p. 56.

34 Claxis, "Suppression and Contro" po 243 " Henry Acanis, The Great Secess jon winter of $1860-63$ and other Essays, Ge George Hockfield (New York: Sagamore Press, 1953). 1. 24: Carl H. Frasur, "Union Sentiment in

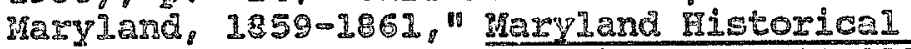
Magagine 23 (September 2929) B PP. 210-2II, 223-22\%。

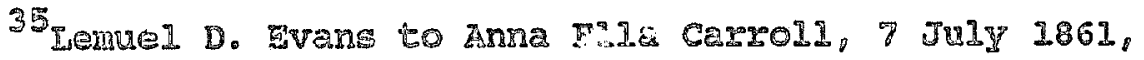
Caysoll Paperig.

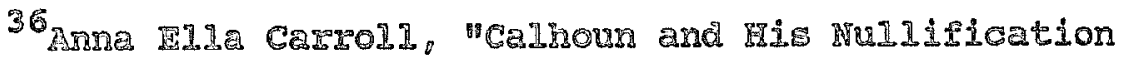
Doges:

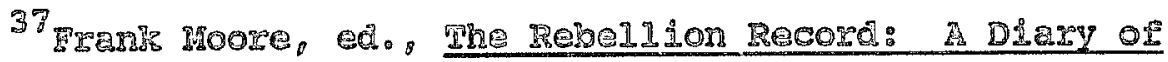


American Events, with Documents, Narratives, Illustrative Incidents, Poetry, Etc. 11 vols. (New York: G. P. Putnam \& Charles T. Evans, 1861-1863; D. Van Nostrand, 1864-1868), $1(1867): 5$.

${ }^{38}$ Ibia., 1:10.

${ }^{39}$ Ibid., $1: 14-15$.

40 Ibid. 18:22-37. If quantity were the only measure, Evereti's opinion might make more sense, but the sentence to which he refers makes calhoum's position on the right of secession quite clear: "That a state, as a party to the constitutional compact, has the right to secede,-acting in the same capacity in which it ratified the constitution,--cannot, with any show of reason, be denied by any one who regards the constitution as a compact. . . " Jonn C. Calhoun, "A Disconrse on the Constitution and Government of the United states " in The works of John C. Calnoun, ed. Richard $\mathrm{K}$. Cralle, 6 vols. (New York: Russe11 \& Russel1, 1968), 1:301.

41 Hoore, Rebellion Recora, $1: 41$.

42 Carrol1, "Calhoun, p. 444.

43.Ibid. p. 445. Calhoun's Fort Hill address was mace 26 IนIY 1831.

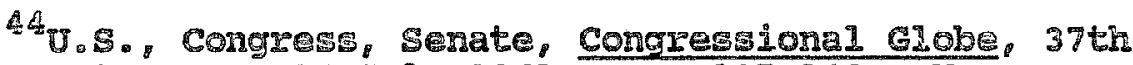
Cong. lst sess., 16 JuIY 1861, Pp. 137-142: hoore, Rebelilon Record, $2(1867): 32$; washington Daily Nationad Intelligencer, 17 July 1861.

45 Moore, Rebeliton Record, 2:58; Anna Ella Carro11. Reply to the Speech of Hon. Io C. Breckiniage, Delivered in the United States Senate, July 16,186 I $_{\text {, and }}$ In Defense of Ehe President's War Measures (washington: Henry Pollinhorn, 186I), R. 3.

4f Carrol1, Reply to Brealoinriage, 9. 3; Lucilie steildwe11, John Cabell Breckinridge (CaIdwell, Idaho: Caston Printers, 1936), pp. 99-105.

47 Brearinridge, Congressional Globe, 16 JuIy $1361, p$.

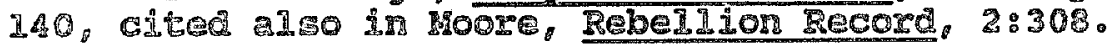

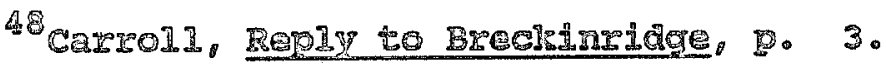

49 IDIA. PQ. 4-9. For a detailed nistory of the 
conspiracy of which Carroll wrote, see Thelma Jennings, The Nashville Convention: Southern Movement for Unity 1848-1851 (Memphis, Tennessee: Memphis state University Press, 1980).

${ }^{50}$ Carrol1. Reply to Breckinridge, p. 9. Norma Cuthbert, Iincoln and the Baltimore Plot (San Marino, California: Huntington Iibrary, 1949) details the plot to assassinate Iincoln as he changed trains in Baltimore. See also Nevins, The Energence of Iincoln, p. 451: Powell, Iincoln Day BY DaY, 3:19-21.

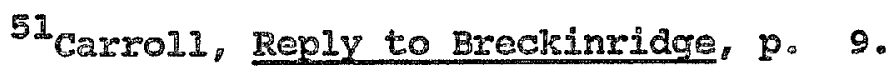

52 Ioid., p. 90.

53 Ioid. See a similar interpretation from a contemporary in Horace Binney, "The Drivilege of the Hrit of Habeas corpus under the constitution" in union Pamphlets of the Civil War 1861-1865, ea. Frank Freidel. 2

Vols. (Cambriage, Massachusets: The Belknap Press of Harvard University Press, 1967), 1:202-205, 252. Iincoln defended his actions in his Message to congress in special Session, 4 July 1861: see Basler, Works, 4:421-441.

${ }^{34^{3}}$ The question of the Confederacy's gtatus vig a vis belligerancy is discussed in J. G. Randa11, Constitutional Problems Uraer Lincolr (Gloucester, Massachusetts: Peter Swith, 1963), pp. 51-69. Iudwel1 Johnson discusses the resolution in the matter in the courts in The confederacy: What Was Ito The VIew Irom the Tederal Courts," civil War History 32 (March IS86):5-22. On the definition of beIIIgerent rights see Henry whaton, Elements of International Law: the Iiteral Reproduction of the gaition of 1866 by Rghard Henry Dane. Jr. Coxford: Clarendon PFes: $2936 \%$ PP. 29-32.

55 Besiar, Worke, $4: 430$.

56 Carrol. Reply to Brecirinridge, p. 10: RandalI, Constitutional problems, p. 61 .

57 Rencild aiscusses tho 5-4 supreme court decision in the Prize Cases that decided in favor of the President's actions, Constitutional Problems, pp. 51-57. See also W112ian Whiting, The Mar Porers Undes the constitution of the United States Boston: n.p. 1871: reprint ed. New Yorj: DaCapo Press, 1972 , pp. 38-49 For his statment

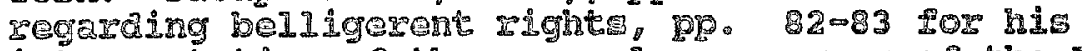
interpreteden of the generel war powers of the Eresident. 


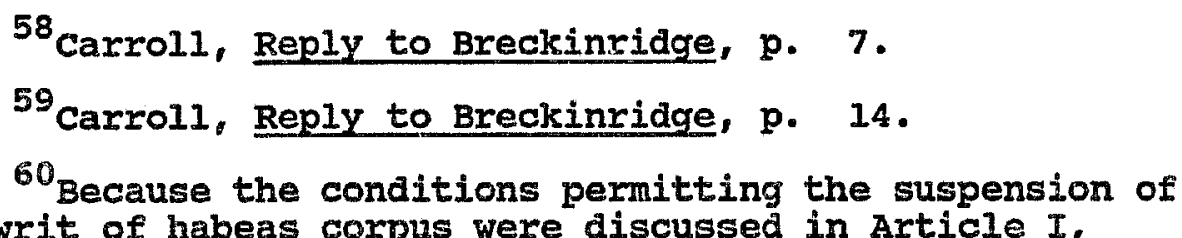
the writ of habeas corpus were discussed in Article I, section 9 of the constitution, which article set out the duties of the legislative branch of the government, opponents of Lincoln's actions argued that he had no right to suspend the writ, and that suspension was obviously a power reserved for congress. Iincoln, carroll and pamphleteer Horace Binney all argued that if, in order to execute the laws and protect the constitution against a rebellion, it was necessary to make arbitrary arrests and sugpend the writ, that power was implicitiy granted to the President in his capacity as commander-in-chief. See Article II, section I (oath to protect the constitution, Section 2 (appointing Iresident Commander-in-chief). Section 3 (requiring President to faitheuly execute the laws). Basler, Works, 4:429-431: Carro11, Reply to Breckinridge, p. 11: Binney, "The Privilege of the Writ," p. 252: Gaker, The politics of continuity, pp. 59-60.

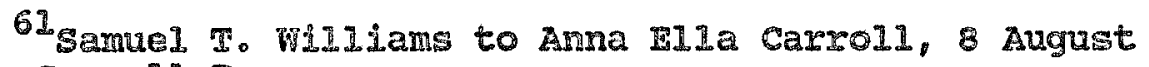
1361, Carrol1 Eapers.

$62 \mathrm{Ca}$ leb Smith to Anna Fla carro11, 25 september 1861, Carro11 Papers: Edward Bates to Anna FIla Carrol1, 21 September 1861, Carroli Papers. Carrol1, incidentally, has thyee cogles of this Bates letter in her papers. Feok copy, al in her hand, is sightly different. There is no doubt thet Carro 11 and Bates mew each other feirly ve11: two other later lettors from Bates make 1 t clear they were on good trrms. Apparenty, Cagroll used this particular Ietter to shore me her claim that the government orojered the orinting of pamphlets she wrote. The firgt version states "I heve sent the Brosldent the cogy you lept" the last, wThe Prosident requested me to thank you most cordilly for the copy you sent. . . ." This incident of editing further reflects carroli'g tenclency to twist reality into that which would reflect her most favorably, making it most difficult for any historian to select which of her claims was true or to what extent any were true.

63 Ama IIIa Carro11 to Abraham Lincoln, 21 June 1862, Gerrol1 Papar: Thomas A. Scott, 28 January 1863 , Gted In

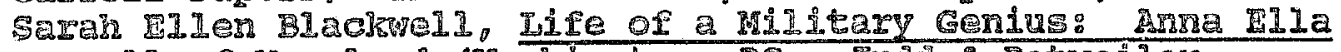
Carroll of Hary 1ane fashington, DC: Juad Detweilder,

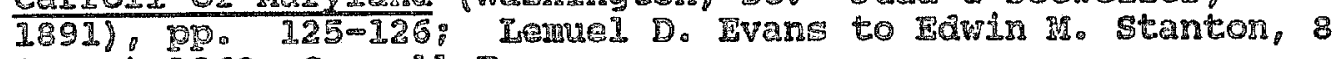
August 1862 , Carro11 Baper. 
${ }^{64}$ Anna Ella Carroll, "The Constitutional Power of the President to Make Arrests and Suspend the Writ of Habeas Corpus Examined" (Maryland: n.p., 1861), reprinted in Sarah Ellen Blackwell, Life and Writings of Anna Ella Carroll (Washington, DC: Judd \& Detweiler, 1895), pp. 92-98; Anna Ella Carrol1, The War Powers of the General Government (Washington, DC: Fenry Polkinhorn, 1861).

65 [Samuel T. Williams] to Anna EIla Carro11, 26 Auguet 1861, Carroll Papers.

66 Ama ElIa Carroll to Jefferson Davis, February 1861, Carrol1 Papers. Davis' reply, in which he spoke of the finality of his "leave taking" from the union, is a copy in Carroll's hand and is of questionable authenticity. Jerferson Davi: to Ansa Ella Carrol1, I March 1861, Carroll Papers: Mary S. Dix, associate editor, The papers of Jefferson Davis, to author, 29 August 1985. Several 1etters from Davis to Carroll survive in Carroll's papers. His responded to patronage requests, sent her money, talked about his family, and pronised to stop by to see her on his vay home, "if my wife does not call for me before the adjourment." Jefierson Davis to Anna Ella Carrol1, 22 December 1857, 20 March 1860, 27 Februaxy 1860, Carroll Papers.

67 Arna 11 a Carro11, Meno on 1361。 MDHS 3650-178, D. 17A, Carroll Papers.

${ }^{68}$ Bruce Catton, The Coming Fury (New York: Doubleday, 2961), p9. 397-401.

69 Panda11, Constitutional Problems, PR. 294-302.

70 Carroll, Memo on War Powers, 2.

${ }^{2}$ Carro11, War Powers, p. 20.

72 Ibid. pp. 10-11. Trumbull had promised a quick introduction of a confiscation bill on the first day of the new session. See U.S., Congress, Sente, Congressional Globe, 37th Cong., 2 a sess., 2 December 1861, g. 1.

73 Anna ELIa Carroli to Thomas H. HICk, 11 January 1862, Cerrol1 Papers: Carrol1, War Powers, p. 12.

74 Carroli, war powers, p. 12. Mhe daea of procuring the abolition of slavery by this war ds the nost chimericed one ver conceived by the intelligent mind . . ." See Carrol, Loose Papers on slavery and the 
Civil War, Carroll Papers, cCJ Collection, MDHS 3622-103, p. 42 .

75 Anna Flla Carroll to Abraham Iincoln, 21 June 1862, Carroll Papers; Blackwell, Life and Writings, pp. 46-48. Carl Sandburg, Abraham Iincoln: The War Years, 4 vols. (New York: Harcouxt Brace \& Co., 1939), 1:410-411 places the seal of the Department of state on her work as does BLaclwell's volume which repints the pamphiet (pp. 48-91), but all dains filed by carroll for payment were with the War Department.

76 J. G. Randall and David Donald, The Civil War and

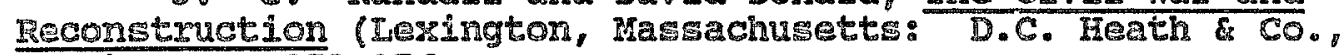
18691 . Bp. $371-376$.

$7 \%$ Anna TIla Carroll to Abraliam Lincoln, 25 Apxil 1862 . Carrol1 Rapers.

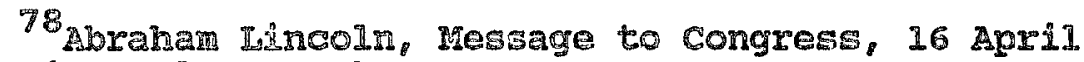
1862, In Basler, woris, 5:192.

79 \%.s., congress, senate, congressional clobe, 37 th

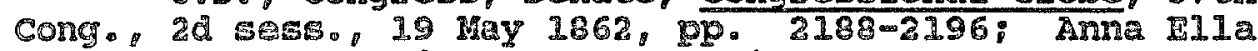
Canra II, The Relations of the National Government to Revolted Citizens Defined PWashington: Renry Polsinhorn, 1861).

${ }^{80}$ Congressional Globe, I9 May 1862, pp. 2189-2190.

81 Ibia., pp. 2190,2192.

ร2 Iฤม่. p. 2192 .

83. Ibia. p. 2193.

84 Tb1d., \$. 2196.

85 Ana Tla Caryol1 to Abraham Ifncoln, May 2862 ,

carrol1 Papers. There was considerable disagrement anong jurists in the 2360 regarding the right of conflscation in time of war. See Randall. Constitutional Froblems, pp. 294-302。

86 Randa1, Constitutional problems, pp. $360-363$.

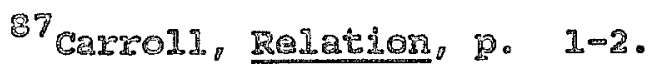

88 Congressional Globe, 19 May 1862, D. $2190:$ Carpol I ReIation. Po 3. 
${ }^{89}$ Carroll, Relation, pp. 3-6.

90 Ibid., p. 6 .

9I Ibid., p. 8

${ }^{92}$ Ibid., P. 12,15 .

93. S., Congress, House of Representatives, Congressional Globe, 37 th Cong., 2d sess.. 22 January 1862, p. 438. Sumner himself was impressed enough with carroll's "Reply" to place a copy of it in Harvard university tibrary in 1862. See Walter P. Armstrong, "The Story of Anna Flla Carrol1: Boljtician, Lawyer and Secrec Agent," American Bar Association Journal 35 (March 1949), p. 199, n. 2 .

${ }^{94}$ See Isincoln $\mathrm{g}$ response to Frémont's and Hunter"s proclamations in Basler, Works, 4:506 and 5:222. Black troops were first organized in April of 1862, and would be officially sanctioned by the wax Department that August. See Randall and Donald, The Civil War and Reconstruction, pp. 391-392.

95 Anna E11a Carroll to Abrahan Isincoln, 4 July 1862 , Cazroll Dapers.

96 Anna EIIa Carroll to Abraham LIncoln, 14 JuIy 1862, Robert Todd Iincoln Paper:, Iibrary of congress, Washington, DC。

97 Bas1er, Worghs: 5:331: Randa11, Constitutional Problems, pp. $279-280$.

98 Basler, Worjs, 5:329-330: Randa1, Constitutional

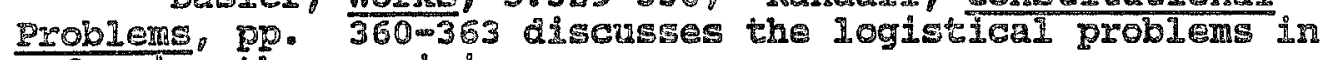
enforcing the provisions.

99 See Isincoln's remarps on his emancipation program in his Annual Message to Congress, I December 1862, in Basler, worls, 5:518-537, especiaily 530-536. See also Riehard Current, The Iincoln Nobody Knows (New York: McGraw Hi11, 1958), PP. 221-222.

100 Ana Ela carro11, Manuscript on Slavery, post-1864, MDHS 3652-430, Carroll Papers.

101Join 3 . Fry to Anna Tlla Carroll, 5 April 1861. Carroll Papers: James Grant to Aaron C. Burs. 31 Augrst 1860, Aaron Columbus Burr Papers, Yale undversity, Nev Haven, Connecticut: James Grant to garor C. Burr, 13 
September 1861, "Records of the office of the Secretary of the Interior Relating to the Suppression of the African Slave Trade and Negro Colonization, 1854-72," U.S. Department of the Interior, Record Group 48, National Archives, Washington, DC; Anna Ella Carroll to Abraham Iincoln, 23 April 1862, Department of the Interlor, Record Group 48. (Hereafter citea as DNA, RG48.)

102 Aaron C. Burr to secretary [Caleb] Smith, 6 May 1862, DNA, RG48.

103 James Grant to Aaron C. Burr, 9 February 1861, Burr Papers: Arna Ella Carroll to Aaron C. Bur: 3 September 1861, Burr Papers; James Gsant to Aaron C. Burr., 3 February [1862], Burr Papers: Anze 211a Carroll to Abraham Iincolr, 15 Apri1 1862, Carrol1 Papers. Carrol1 wrote to the papers as well. See Anna Ella carroll to Editor, New York Tines, 6 March 1862.

104Anne Ella carroll to Abraham Lincoln, 23 Apri1 1862, and Ansa Ella Carroll to Secretary Smith, 27 April 1862, DNA, RG45. One reason Iincoln may have used when rejecting the idea was the pro-secession sentiment of many of the eitizens of British Honduras, particularly traders. By early 7863, supporters were eager to accept pree blacks for labor in British Honduras, but only those emancipated prior to the war, since they regarded freedmen as more "intelligent" than "Contrabands." See wayme Briteish Honduras: Colonial Dead End: $1859-1900$ (Baton Rouge, Ioujsiana: Loujsiana State University Press, 1967$),$ po. 22, 30, 38. Casroll also argued for a Central Anerican site for free blacks in the washington National Republican. $23 \mathrm{APR} 11$ 1862.

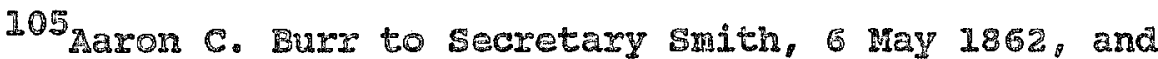
Anna Ella Carroll to Secretary Smith, 13 May 1862, DNA, RG48.

306 Arna Flla Carroll, Recollections of Inncoln, n.Q." MDES 3655-722, pp. 105-120, Carrol1 Papers.

107 Anna Elia Carroll to Aoraham Inncoln, 19 May 1862. Inincoln Papers.

108 1862, carroli Papers. Mitchel1's letter, which describes the President's aelighted ragaton to the box sent and prasses carrol1" Carsol' ${ }^{\circ}$ ' hasd, and may have been used at a later date in ner clalms against the government. It is one of thres 
copies, none of which are exactly alike, and therefore must be viewed cautiously (see n. 62 above). Anna Ella Carroll to Aaron C. Burr, 30 August 1862, Burr Papexs; Basler, Works, 5:370-375.

$$
109
$$

Anna Ella Carroll to Aaron C. Burr, 13 September 1862, Burr Papers. Burr protested the decision to both Pomeroy and Iincoln and warned of dire consequences if colonization proceeded elsewhere, but to no avail. see Aaron C. Burre to Senator Pomery, 20 September 1862, 5 October 1862, Burr Paper: Aaron C. Burr to Abrahan Iincoln, 6 october 1862, Burr Papers; Basler, Worlks, 5:433-436: Anne FII2 Carrol1 to Abraham Iincoln, 21 october 1862, IIncoln Papers. A substantial worf on the Ile A'Vache colony is by Jayme Ruth Spencer, "Abralam Lincoln and Negro Colonitation: The Te AVache, Hayti Esperience, 1862-1864" (unpublished master's thesis, college of WIIliam and Mary in Virginia, Williamsburg, Virginia, 1971).

$$
110 \text { Abraham Innooln to Anna II Ca Carroll, } 19 \text { August }
$$
1862, in Bas1er, Wor:s, 5:381-382; Edward Bates to Anna E11a Carro11, 20 August 1862, James Abram Garfield Papers, Iibrary of Conress, Wachington, DC. These two letters were enclosed in a letter from carrol1 to Garfield in which she introduced horself and her clain against the governent. Basier mistakenly has the Lincoln letter in Carrol1' $\mathrm{g}$ hand: both letters were copies, but not in carroli's handwriting.

\section{2}

Basler, Woris, 5:423: Ama wla Carroll, 15 April 1862, I4 JuIy 1862, Carroll Papers. 


\section{Csapter 5}

\section{Carroll stakes Her Claim}

In the summer of 1862 , Anna El1a Carrol1 met with President Iincoln. She presented him with a bill for the pamphlets she had written. He dismissed hex proposal that she travel to Europe to write for the Union with such vigor that she did not discuss her second proposal: that he pay her for her worls as a military strategist. She had written out the introduction of the idea to Iincoln-w Now. Mr. President, there is arothex subject, which I desire to bring to your attention"-laut her audacity seems to heve

deserted her. - Not for long. The legend of Carroll as a military genius was about to spring forth.

Carroll claimed to have aiscovered a route to invade the confederacy that would bypass strong Confederate fortification on the Missisgippi River. Her account, as she prosenced it Ir lacer years, is as follows:

Ir ear I October 1861, ghortly arter making her oral 
agreement with Assistant secretary of War Thomas A. Scott to write pamphlets for the War Department, Anna Ella Carroll left the comparative safety of Washington to discover for herself the state of the Union in the western theatre of the war. She went first to Chicago, then to st. Iouis, where she met her old friend and close companion, Lemuel D. Evans, Who had been sent to st. Lowis on a secret mission by secretary of state william Henry seward. 2

To her dismay, carroll found st. Louis to be a hotbed of Confederate sympathizers and discouraged Unionists. She decided to continue writing pamphlets arguing for the Union cause and went to the Mercantile Library in Sib. Louig to do research. There she met the Iibrarian, who was the brother of the confederate gereral, Albert Sidmey Johraton. She engaged bim in a varm discussion, for he was a confederate sympthizer and expressed surprise that, as a southers lady, she should be so avid a supportar of the union cause and should be using her Iiterary talents in such a losing cause. Sensing his dikbelief that her convictions were firm, Carroll flattered and chamed ber way into Iolbrarian Johnston's confidence and took note of all he said. She also took note of what all those around her waid and eventuliy decided to share the infornation she had gathered with the Union anthorities. She went to see General John C. Frémont, who was in charge of the vestern Daparment, but he was absent and only "his 
wife was in command. ${ }^{3}$

Not deigning to share her information with Jessie

Fremont, Carroll kept all these things to herself and

ponderea them in her heart. She knew that President Iincoln had decided that the Mississippi River must be controlled by the Union in order for the Morth to win the wax. But all to whom she spoke assured her of the strength of confederate fortifications down the river and of the impossibility of opening It. Furthermore, after witnessing the disheartening effects on Union sympathizers when they saw the injured and dead federal soldiers after the Battle of Belmont on November $\%$, she was determined to find a safer way for Union troops to Invace the south, a way that bypassed the fortified Mississippi.4

There were two other rivers besides the Mississippi

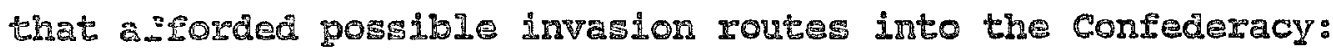
the Tennessee and the cumberland. carroll reasoned that if she conld talf to a I I Iiver, she might be able to learn if the rivers rould be navigable by Union gumoats. Fortunately, in the same hotel where carroll was staying, there resided one Ana scott.

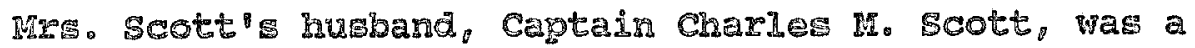
riverboat pilot and, in fact, had piloted the tranport Memphis at the recent Battle of Belmont. Carroll asted Iirs. Scott to Iet her Bnow the monent her ausband raturned, and accordingly, carrol sent for him immediately upon his 
arrival in the city. 5

When Captain scott arrived, Carroll questioned him intently on the characteristirs of the Tennessee and Cumberland Rivers. She discovered that the Tennessee was always deep enough for gunboats: the cumberland was deep enough most of the time. At that moment, Carroll had a flash of inspiration. She knew in an instant that an inrasion route that used these two rivers was the solution to the strategic problem that had puzzled the military leaders in the west and planners in the Fast and had kept the army frozen in its tracks, fearful of another raid with the death toll, disarray, and failure of Belmont. 6

Iemuel Evans called to see carroll just then, and Carroll turned to hin with her idea that the federal troops should be transferred from the Mississippl to the Tennessee River and should ase that route to invade the confederacy. Sinee Evans had been born near the Temmesse River and had Iived near Muscle Shoals in Alabama most of his life, Carrol. trusted his opinion as an insider. He concurred with the value of hex plan of invasion, and carroll and Evens went to captain scott to glean as much information Irom him as possible. She then wrote immediately to Atrorneymeneral Gaward Bates, who had first suggested using gurboats, But on the Missiagippi River, ${ }^{7}$ then to Assistant Secretary Thomes A. Scott, and then to President Iincoln hinself, detaiting her plan and promising to return to 
Washington to explain it in more detail. 8

Carroll then left st. Louis and traveled to ohio, covington, Kentucky, and then on to Buffalo, New York, where she met with her old friend Millard Filimore. Everywere ghe wert, the talk was all about the necessity of controlling the MIssissippi by storning its defenses. In Buffalo, Fillmore listened to carrol1's nur plan and agraed that it was woncerful discovery. He urged her to waste no time, but to present it to Iincoln at once. 9

She arrived in washington in Iate November and began Wor jo immediately. On November 30 , her maps drawn and hew papers finished, she called on colonel scott at the War Department wits a detailed plan of attack.

The civil and military authorities seem to be laboring

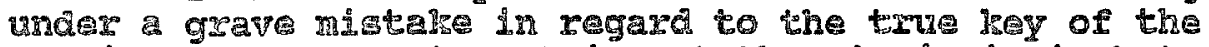
war in the southwest. It is not the Mississippi, but the Tennessee River. It is well hnom that the eastern part or the farming interests of Temnessee and IRentuaky are generally loyal, while the middle and restern pantw, or what are known as the planting

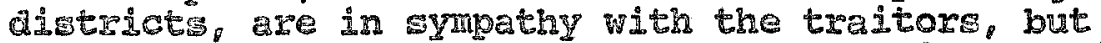
except in the extreme mestern part the union sentiment stid IIves.

Mow all the military preparations made in the west indicate that the Mississippi River is the point to which the athorities ase disecting their attention. Or that river many battles must be fought and heavy risks must be incurred before any impress made on the mesty 211 of thich could be avolded by using the Tennessee River. This is navigable for first-Class boats to the ridsaissippi line, and is open to ravigation all the year, vhing the distance is onIy

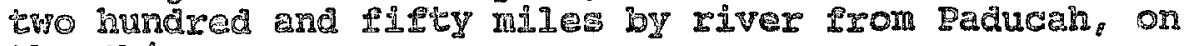
the ORd요.

The Tennessee River offere many advantages over the 
Mississippi. We should avoid the most impregnable batteries of the enemy which cannot be taken without great danger and great risk of life to our forces, From the fact that our boats, if crippled, would fall a prey to the enemy by being swept by the current to them and away from the relief of our friends. But even should we succeed, still we will only have begun the war, for we shall then have to fight to the country from whence the enemy derives his supplies. Now, to advance up the Tennessee River would avoid all this danger, for if our boats were crippled they would drop badr with the current to their friends and escape ali damages. But an advantage still would be a tendency to cut the enemy's lines in two by reaching the Memphis \& Charleston Railroad, threatening Herwphis, which lies about one hundred and fifty miles due west, and no defensible point between; also Nashville, only ninety miles northeast, and Florence and Tuscumbia, in North Alabana, forty miles cast. I movement in this direction would do more to relieve our friencs in rentucky, and inspire the loyal hearts in East Tennessee than the possession of the whole Mississippi River. If wel I executed it would cause the evacuation of al1 those formidable fortifications on which the rabels ground their hopes of success: and in the event of our fleet attacking Mobile, the presence of our troops in the northern part of that state would be of material benefit to the fleet. Again, the aid our forces would receive from the loyal mer in Tennessee wuld enable then to crush the last eraitor in that region, and the separation of the two extremes would do more than one hundred battles for the Undon cause.

The Tennosse River id crossed by the Memphis \& Louisville Railroad [the Remphis \& ohio] and the Jemphis \& Nashvi110 Railroad [probably the Nashville \& Decatur] at Hamburg, where the river malnes the big berd to the east and touches the northeast corner of Mississippl, entring the northwest corner of Alabama, forming the arc of a circle to the south, nters the State of Temessee at the northeast of Mlabana, and if it does not touch the northwest comer of Georgia comes very near it.

It is but eight wiles from Hamburg to the Memphis \& Charleston Railroad, which roed goes through Tuscumbia, and only two miles from the river, which it crosses at Decatur, thirty adies above, intersecting whth the Nashville \& Chattanooga road at stephenmon. 
Alabama.

The Tennessee River never has less than three feet to Hamburg on the shoalest bar, and during the fall, winter and spring months there is always water for the largest boats that are used on the Mississippi River.

It follows from the above that in making the Mississippi the key of the war in the West, or rather in overlooking the Tennessee River, the ${ }_{1}$ fubject is not understood by the superiors in command.

Carroll read the paper out loud to scott, slowly and carefully. Greatly excited by the brilliant strategy conceived by the lady from Maryland, scott begged her to allow him to take her plan to the President, who had already read her earlier letter and who was eager to see her final draft. If it would be of aid to her country, Carroll would leave it. so assured, she left the plan with colonel scott. ${ }^{11}$

Jincoln emoraced the plan with enthusiasm. He fired Secretary of War simon Cameron because he was too old to carry out this new strategy and brought in the unpopular but young and anergetis Ifwin stanton. stanton sent orders immediately to General Henry Halleck who had tajen command of the Western Department. Ha1.1eck ordered General Ulysses Grant up the Tennessee River to the Confederates' Fort Henxy and, caryyng through Carroll's strategy, continued the Union advance toware the rail Junction of corinth, Mississippl. colonel scott was sent vest by InIncoln to ensure that Falleck and Grant understood the ovarel stretegy and carried ouc the plan fajthisly. 12 


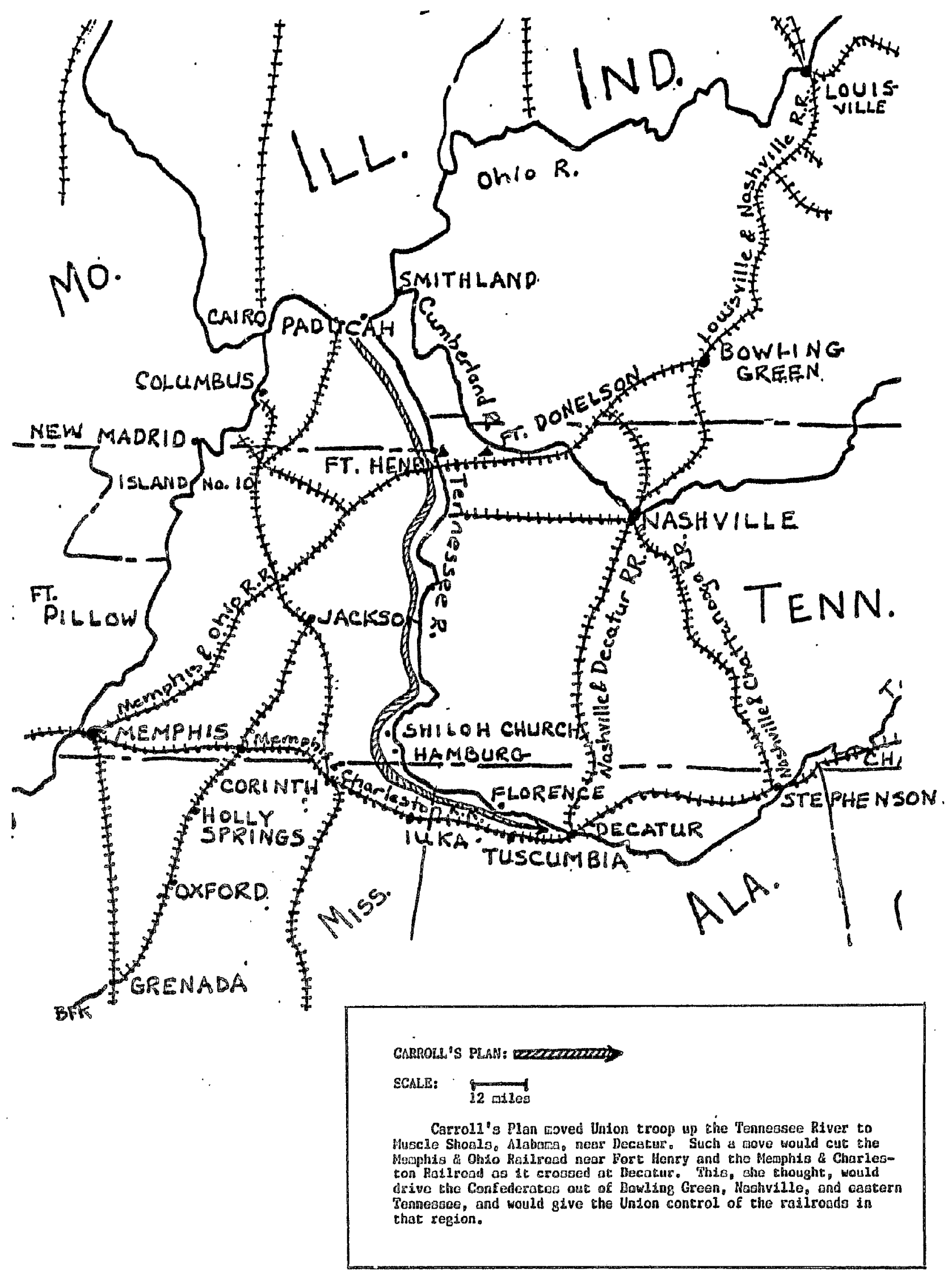


The importance of the successful campaign in Tennessee cannot be overestimated. With an all-encompassing sweep of hindsight, Carroll's supporters claimed that, Because of her plan, the Confederacy was cut in two, Confederate fortifications on the Mississippi were evacuated, the enemy was driven inland from the outer borders of the confederacy, European intervention on behalf of the south was prevented, the Northwest remained in the Union, the national credit was revived, unionist sentiment in the Border states was reinforced, contact was made with the slave population that turned them against the Confederacy and toward support for the Union cause, Missouri. stayed in the Union, Vicksburg was captured, and the union was saved. ${ }^{13}$

Shortly after the fall of Forts Henry and Donelson, legis lator: in both houses of congress sought to reward the brijIIant genera whose strategy had saved the Union. Major General Halleck, Brigadier General Grant, Brigadier General Don Carlos Buel1, and FIag Officer Andrew Foote were all mentioned. Anne Carroll gat in the gallexies, listening to the debates with a secret smile on her face. Iincoln, stanton, scott and Evans all Jnew the secret, as did Benjamin Wade, chaiman of the recenty-iormed comittee on the conduct of the War. But they alI jnew as weII the dangeg of allourng the identity of the anthor of the plan to be knom. As Incoln was poeticaly to have sald, "The 
officers would throw off their epaulets if they knew they were acting on the plan of a civilian; and good God, if they knew it was a woman, the whole army would disband! "14

So silence reigned and those who searched for a hero eventualiy gave up their search and resumed the business at hand. The woman whose wor: had saved the union turned her own hase to other matters, not the lease of which was trying to obtain payment for her pamphlets from the War Department. only years later did carroll reluctantly allow herself to be pulled forth from her feminine obscurity to be presented to the American people as a true hero to be recognized and Iiberal1y rewarded.

Thus had begun the fantastical legend of Anna Ella Carro I1, "Iincoln's Iady strategist," the "Great Unrecognized Hember of Lincoln's Cabinet," "The originator of the Temnesse campaign" and, at its fuldest flight of fancy, "The woman who Saved the Onion." And thus had begur another intance of carroll misperceiving and twisting reality until it suited her purposes. ${ }^{15}$

Against this legend stands the more comonly accepted version of vents that culmineted in the Tennessee River campaign. The Union was in dire straits atter the Battle oI BuI1 Bun in JuIy 1861 and months of inaction by his genera1: had dxiven Iincoln to despair. General in Chief Winfield scott had conceived of an overall strategy at the beginsing of the war that would surgound the confederacy 
with a land army and a naval blockade. With a "powerful movement down the Mississippi to the ocean" to cut off interior trade adied to the external pressure, the "Anaconda Plan" would gradually squeeze the life out of the South. ${ }^{16}$ Control over the Mississippi was essential. It would cut the Confederacy in two, blocking food, supplies and contact from the agricultural states of Tuxas and Arkansas, and block importation of war materiel from the Northwest as vel1. 17 But scottia plan would take far too Iong to work. The political situation demanded a quids end to the war. East of the Mississippi River were the Tennessee and Cumberland Rivers. Part of their courses ran northward through Tenmesse, emptying into the Ohio River. These rivers were the natural highways of the region and the confederates were quich to fortify then. Prinary fortifications were Fort Hempy on the Temasese and Fort Donelson on the cumberiand.

By September 1861, General Grant, under comand of Major Grmeral John Fumont, head of the Western Department, had establisined fis headquarters at cairo, I11irois, on the Missigipioi. He sad seised and reinforced the citieg of Paducah, at the mouth of the Tennessee, and smithland, at the mouth of the Cumberland. ${ }^{28}$ By mid-october. Union gurabots were reportid thirty miles below fort Henry, and the consederatas yere fearisul of a union push up both rivers. The cumberland was "in fine boating order and 
rising quite fast," and would stay deep enoigh for gunboats through the fall and winter. William $w$. Mackall, Assistant-Adjutant General to General Albert sidney Johnston, urged Confederate General Leonidas Polk to hurry and finish reinforcing Fort Donelson: "the necessity of interrupting the cumberland is urgent." If the union forces were to invade Tennessee by water, they would be able to push on to the Memphis and Ohio Railroad which ran fror Memphis to Bowling Green, and eut this important rail comnection. 19

The Union forces under Grant were quite cognizant of the coniederates fear of thair designs. On Hovember 8 , Brigadier Gemeral charles 1 . Smith wrote Grant from Paducah that confederates at Fort Henry had ween under apprehension af atback from here for the papt two weeks." Indeutenant 5. Ledyard Phelps of the Union Navy was Monstanty moving his vessel [the wooden gunbot conestoga] up and dom the

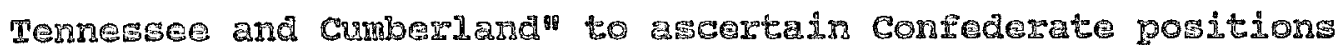
and strengts. On sovember 20, Colonel charles hittlesey of the Corps of Enginears suggested to Halleck that a jolnt land and water move up the Cumberland and Tennessod Rivez: "the most passable route into Tennessee" Confederetes In Colmbur, 10rce Brigadier General simon Bolivar Budkner to rgtrat, and provide a water route halfrgy to Mashvil1e, all of which would serve to drive the conrederetes out of central Tennesser. 20 
If, contrary to Carroll's assertations, the military minds in the West were aware of the strategic importance of the Tennessee and cumberland Rivers; if, contrary to what she reported, preparations were being made to invade the South by these rivers rather than coneentrating Union forces solely on the Mississippi, then why was there no action in the late fall and early winter of 1861 ? Carroll would always believe that it was her letter to the War Department on November 30 that had informed the Western Department of the value of the rivers and that her plan had prodded the Union forces into action-the action that oventually led to the capture of Forts Henry and Donelson in February, 1862. But carrol1, as a civilian and an outsider, did not have the complete picture of the state of affairs in the restern theatre. It was not a lask of intelligence or strategic understanding that gept the union forces immobile. Supply shortage:, batting comanders, a lack of coogeration betweer army and nery, inexperienced troops and sailors, and nominal suport from washington all contributed to the Union's faidure to move repidy on the vesterr rivers. At the time of President Iincoln's proclamation of the naval blockade of the South, the United states Havy consisted of forty-two comissioned veswels. These vere deepwater ships, totally ungited for use on the inland water of the var's western theatre. 21 Navy commander John Rodgers Wag Bat weat in May to establian navad forces on 
the river. First under the command of Major General George B. Ncclellan, head of the Department of the ohio, in July Rodgers fell under General Fremont's command when the the Nestern Department was organized. Rodgers worked hard, purchasing three river steamers in cincinnati and pushing for their conversion into armed gunboats. still, it was August 12 before the alterations resulted in three low-lying vooden gunboat. ${ }^{22}$ These gunboats, though usable, were not amnor-plated. So in August as well, a contract was made with James $B$. Fads of $s t$. Louis to build seven armor-plated gunboats to deliver downriver to cairo. Eads had volunteered his knowledge of the Mississippi, Tennessee, and Cumberland Rivers to the government in ApriI 1861. "Once close them," he wrote,". . and starvation is inevitable in six months."23 The gunboats built by Eadr" company were promised for octobers 10.24

By September, Rodgers had been relleved by captain Ardrew $\mathrm{H}$. Foote for exceeding his authority in buyng the first gunboats ard for being too busy to pay proper obeisance to General Fremont. 25 ceneral Grant, at cairo by Septexber, employed the wooden gunboats provided by Rodgers in taking Paducah and smithland, but it not until october 12 that the finst ironclad was launched and avallable for Union use. 26 Captain Foote was short of money and mpplies for both bre wooden and the ironclad grnboats and pleaded with Secretary of the INavy GIdeos WeIIes, Quartermaster-Genera 
Montgomery Meigs, and secretary of war Cameron for help. "The officers and crews of the three gunboats already in commission are clamorous for their pay." he wrote. Tired of being continually placed "in a most embarrassing position," Foote nevertheless performed miracles, drafting crew members from steamboat men, Great Lakes' sailors, and even the arny, promising payment for supplies, kounding his superiors, 27 and occasionally fighting the confederates with skimishes and raids on their positions along the rivers. 28

one of Captain Foote's problems was his rank. As a captain in the Navy, he was the equivalent of a colonel in the army. He finally requested Fremont to recommend that the Navy Department appoint him Flag Officer of the Western Flotilla, a rank designea to prevent a situation whereby "the gumbats are Iiable to be diverted from the service which I krow you might wish, even by a volunteer colonel of a single regiment, should he happen to be in command in the vicinity of the gumboats." 29 welles gave him the appointment he requested on November 13, 1861; Fremont had been removed and repliced by Genetal Henry Halleck on Noveraber 2.30

since the beginning of the war, there had been three aiferent amy comander, two different naval commanders, a Exantic dash to buy, convert, bulid, eguip, and mas as many gunboats as posalble, all wille dealing with a short-sighted and occasionaly recalcitrant govermenc incapable of paying 
its bills on time. The wonder was not that the Union forces had not moved by late November, when Carroll presented her plan that had supposedly enlightened then as to the "true key to the west." The wonder was that they moved at al1--which they did with decisive vicicories after the gunboats vere available. Grant and Foote both sent messages to Hallecls on January 28,1862 , that they wanted to move upriver to take Fort Henry. Halledk approved their request on January 30. On February 3, Foote led his seven gunboats up the Tennessee, followed by Grant's troops on transport shipg. Fort Henxy fell on February 6. Grant marched overland to Fort Domelson, which fell on February 16. Ironicaily, the gunboats for which the Union forces had waited were almost suparfluous. Fort Henry had been practicaly abandoned by the confecierates, but still, it was so guichly reduced by Foote' ${ }^{\circ}$ fire that Grant's troops wre not needed. Fort Donelson's batteries, on the other hand,

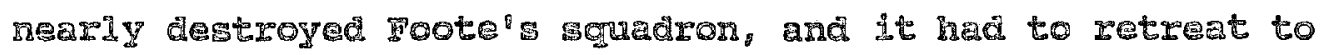
Iet the army nave its day. 31

If the strategy of invading the confederacy by way of the Tennessee and Cumeriand Rivers was well established prior to carrol''s trip to st. Louds if actiong had been delayed due to logisticg instead of strategic incompetence, how did the legend of Carroll as "Iincoln's Searet wempon" begin, and how did It maintain itgelf in what has becowe one

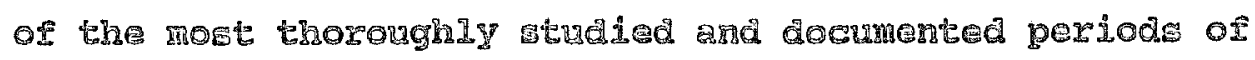




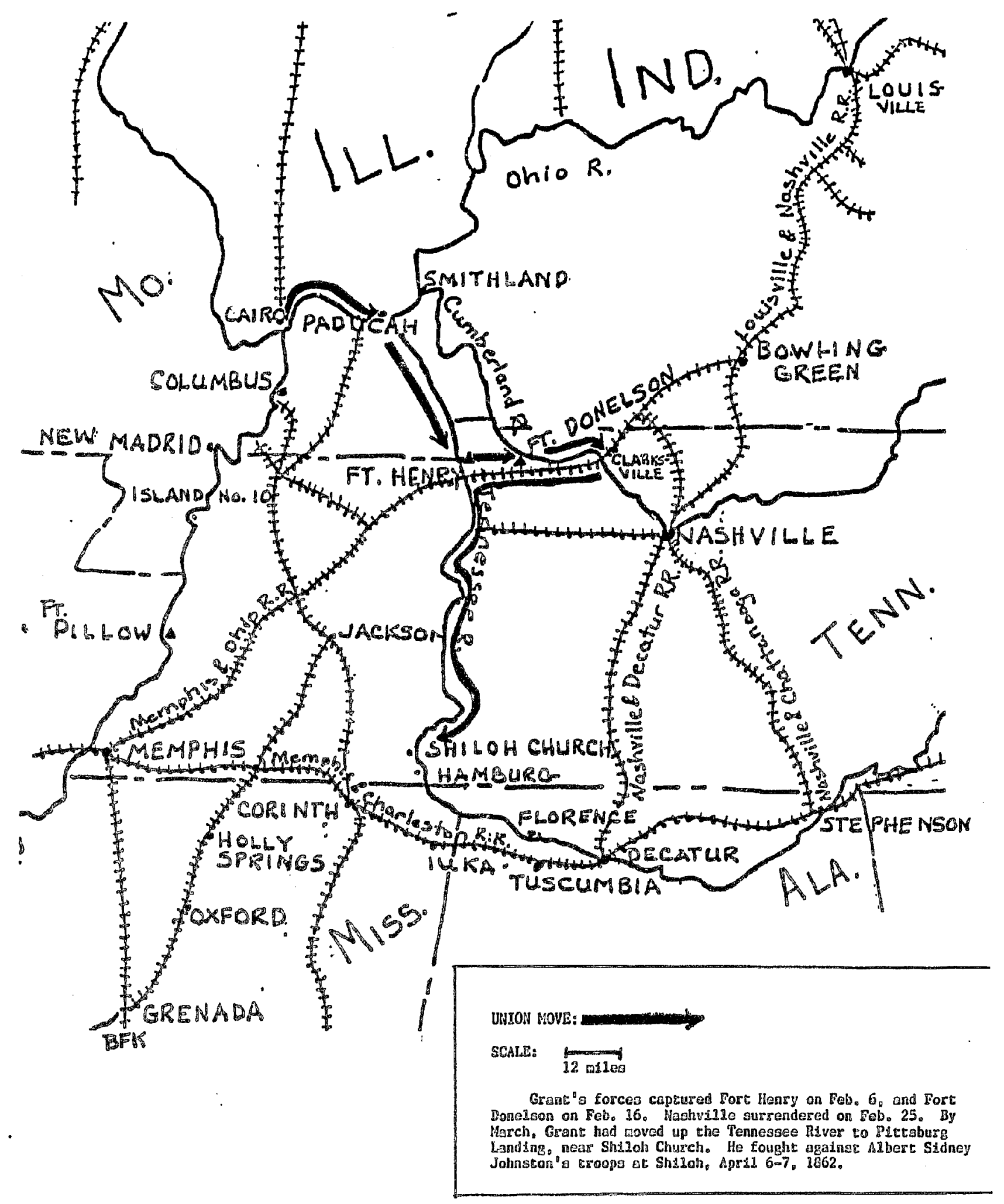


American history? ${ }^{32}$

The legend began with Carroll herself. As always, whenever an event occurred in which she could legitimately claim a small part, Carroll's ego soon enlarged her contributions to monumental proportions. Thus, she wrote Iincoln in the summer of 1862, "I became satisfied that the effort then making to open and hold the Mississippi by an expedition downward could not succeed, and that the true key, was the rennessee river . . . I impressed these views upon military men, wherever I met them, until I returned to this city, the latter part of November, when I gave the result of my observation to the covernment..." As far as carrol. was concerned (and as a civilian untutored in military matter it was not an unreasonable belief on her part), that campaign in Tennessee in the winter of $1861-1862$ had come from her ideas presented on November 30 . "If this espedition was planned . . upon any other suggestions," she wrote, or "if it originated with any one ise, I am not aware of it." Nore important, "if the plan of the Western campaign was based upon the facts, furmished by me, to the secretary of war . . I ought now to have a substantial and Iiberal recognition or this service。 ${ }^{33}$

Herein lay the crux of the matter. As always, Carroll was trying to malse 2 Iiving. The var had provided her with an unprecedented opportunity as a writex, and apparenty her agrement with colonel scott had prompted her 
trip to st. Louis. Since her military strategy had been presented in written form, no doubt Carroll had deciaed that any intellectual labos, particularly one with such monumental results for the Union, would be compensable under her agreement with scott. ${ }^{34}$ In July, 1862 , six months after her second pamphlet supporting the President's policies had been issued, Carroll had not yet been compensated for her work. The handsone scott, whom Postmaster-General Montgomery Blaix had once characterized as a "corrupt lobby-jobber from Philadelphia, "may have overstepped his authority when promising carroll payment for her approved pamphlets. ${ }^{35}$ scott was gallant enough to admit to the oral contract, saying that all his "interviews with Hiss Carroll were in my opideial capacity as Assistant Secretary of war, and in that cepelty I would have allowed, and believed she should be paid, the amount of her bil1. . . ${ }^{36}$ The bill had been partially paid, but that paynent was out of scott' $\mathrm{g}$ ow pocket. 37 "Reply to Breckinridge" nad been circulated at a cost of $\$ 1,250$, which scott had given Carrol1: The war powers and "Reply to Sumner" would cost the government $\$ 5,000$ more. While a bit steep, the bill for the gamphlets was not outrageously so, and, moreover, Carroll had done the work.

What Scott could not have foreseas was the rapid rise of Instation, The war Pohers, Carroll declared to Iincoln, "was destired to Jtand, as Iong as the Declaxation 
of Independence . . ." Accordingly, when she "considered the time and labor the document had cost me . . I thought, fifty thousand dollars a small sum." 38 carroll had mentioned this mind-boggling sum earlier in a letter to Scott replacement in the War Department, Assistant Secretary john pucirer (Scott had been sent west early in 1862 to ascertain the condition of troops and railroads for the new Secretary of War, Edwin stanton). ${ }^{39} \mathrm{BY}$ JuIy, when she met wish Iincoln and read a paper considering her ciaim aloud to hin, she had modifled her bill somewhat by including a proposal that she make a trip to Europe to disseminate union propaganda. IJincoln, whose own salary was but \$25.000 per annum, told her he thought her proposition 1 ithe most outrageous one ever made to any government on earth, "to which carroll had responded stiffly that vthe difference between us, was in ous view, upon the value of intellectue Iabor, in the admingtration of government. The interview was closed, but the mtory got out and Carroll was mortified to hear hex proposition and Iincoln's reply discussed "at a public dimner table in a hashington Hotel - . - It was alear, she thought, that the President hed misunderstood her proposition. The sum was vast, but considering the $\$ 5,000$ already orded her, the cont of journeying to Europe, Einding a place to stay, keeping

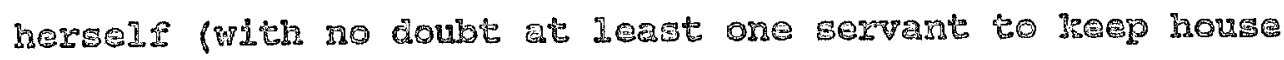
while she wrote) and then argaging for bre publicaton and 
"circulation of my documents among the millions" in Europe, $\$ 50,000$ was "a very reasonable sum." She warned the Fresident, scattering her commas heedlessiy:

". - physical force, alone, however strong it may be, can never bring this war, to a successful termination: unless, you avail yourself, of intellect, to make clear to the popular mind, the issue, about which, the country, is now, at war." There was not any "fair minded man" alive who would call her bill "absurd, or urjust." If it was too high, the error was not hers, "but that of the friends of Yourself, and of the country, who had approved it. But, if he coula not bring himself to admit the value of her noble service to the Union cause, she roula continue with love of country in her heart, "to labor for the salvation of our Iiberties to the pery extent of my ability, as heretofor without any pecuniary reward, or the hope of any" 40 mhere is no indication ir this Ietter to Jincoln that caraol had included in her proposition a bill for her services as a strategigt. In truth, her conscience may have baen nagging at ner, however briefly. For the Tennessee Campign, the most long-lasting alain to fame Anne carroll ever possessed in her constant search for power and recognition, was not solely her idea. While denying Carroll's Glain as a miltary strategist in terms of timeliness has been comon among historian, tew realized that the plan's most salient features were most IIfely 
plagiarized from the work of her contact in St. Louis, Charles M. Scott. 41

Charles scott was a Mississippi riverboat pilot. Unlije the vast majority of his colleagues, scott stayed with the Union in 1861. Fe had fled New orleans at the outbreaje of the war and made it up the Mississippi to Hemphis, where he was captured by Brigadier General Gideon Pillow. Rerusing to swear allegiance to the confederacy, he escaped from custody and made his way to cairo, IIIinois, by June 19. He described the confederate batteries he had seen in the Menphis area to union offichals, then went on to St. Louis to escort his family to onio for safety. 42 scott's version of the events that led to the development of an organized plan to invade the south by using the rennessee and cumberland Rivers differed a bit from Carro11's story. When scott heard crant had been given a command in cairo, he returned to the area in late Sepiember and volumteered his abilities as a pilot. He knew the topograghy of the area weII, having been a leel-boatman on the Iennessee and having hunted in the area around the cumber land as a boy. He had often discussed the usefulness of the rivers as invasion routes with loyalist friends, but did not discuss the strategy with Grant beacuse he thought Grant woud : soon be removed from command. He was, however, willing to share informetion on the river defenses with the General, and had serwed Grant as a pilot of one of the 
transports at the Battle of Belmont on November 7 . His "front seat" at the raid had bothered him enough that, suffering from insomnia, he betook himself to write a letter to his wife, Anna, who had come back to St. Louis to be nearer scott. Anna received the letter November 10 and shared it with the other ladies at the hotel's dining room. one of the ladies present was Anne carrol1. 43

Why carroll was in st. Louis is unclear. She may have gone there, as she claimed, to survey the territory and report back to colonel scott in the war Department. She did have relatives in st. Louis, but clearly was not staying with them (purportedly her sister-in-law's family, who were first cousins of carrol1's, were secessionist). 44 she may have merely come along with Lemuel Evary, who seems to have been on a jegitimate mission for seward. At any rate, Carroll telped to tvang about the letter Mrs. Scott had received, and Evans requested a meeting with the pilot. The co11owing sunday, November 17 , scott met both carroll and Erans:

one conversation led to another, and before long scott was telling Ivans and carroll (after assurances both were "agents of the goverment" 45 , that the "true key to the west" was the Temessee River and that the rissisyippi was too heavily foxtified to allow an invasion domstrem. gvans lunew enough about the topography of the area to understand scott' opinion and know its value. He urged 
scott to communicate it to the authorities, but scott protested that he "was not a good writer anyhow." Carroll, an almost silent partner to the conversation because of her deafness, was leaving the next day "with dispatches" for Washington. Scott, said Evans, could write to her, and she would place his plan before the war Department. 46 Scott wrote to carroll twice, sending the first letter about November 23 , the second about December 15 . By mid-December his opinion of Grant's stayingmpower had improved, and he decided to share the plan with him as well in hopes "It might leac to something, perhaps to a command [by crant] of the expedition."47 By February 4, he wrote his wife that the Union forces were in sight of Fort Henry - - . I think the this nove is the beginning of My

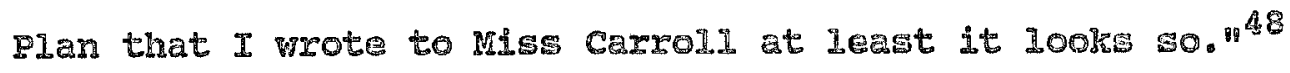
After the fall of Fort Henry on the 6 tir, he was convinged that we will continue on untill [sic] we reach the state of Mis:issipoi when I thing we wid end the Far by talring the Remphj: and Chariestor Rail Roaa. "49 Scot'" optimism was premature, but union forces did continue to move south toward the rainroad center at corinth, mismissippi. Scott continued to write to carroll as well as his wite. Caxall passed along ideas and strategy to stanton. Scott'g brother, E. A. SCOtt, 430 corresponded with Carrol1. Whrough him, she gained acces: to charles's letters to his wife Mnn, with their descriptions of bettes and army 
Iife. 50

Charles scott wrote vividly and well of his

experiences, in spite of what he saw as a "deficiency in grammar, that causes him to smother his writings." 51 His letters portray a man who loved hif country and sought to serve its interests. He sent a detailed account of the navigability of the Illinois River to Representative Frank I. Blair, along with the promise of more information on western waterways if it was needed. But, he wrote Blair, "I wish you to distincty understand that I am not an Applicant for office direct or Indirect but am only Influenced by the hope that I may do some good by giving the facts to you. ${ }^{52}$ In fact, when Carroll proposed she use her influence to get him a position, scott told her he was "unsit by Education for any office in . . Government but that of the Iowest," and he did not want to taire jobs away from those more competent, or from those more needy, such as wounded union soldiers. 53 Fis job as pilot, wile not as lucrative as he could wish, nevertheless provialed him with what he needed.

Scott wrote to Carsoll throughout 1862 , sending her his opinions of military serategy. He thought delaying the Unjon move up the Tennessee to take Fort Donelson had been

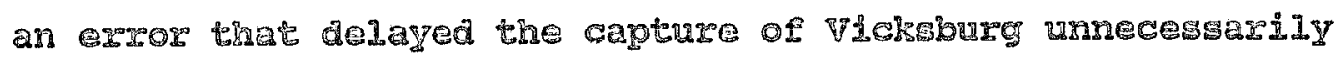
(a Wiew thet feiled to take into account the obvious threat posed to Union forces by Confederate troops from tre fort if 
left unreduced). ${ }^{54}$ He also thought that a union victory in the eastern theatre would send confederates fleeing into Arkansas, Louisiana, Texas, and Eventually Mexico. Gunboats at the mouths of the Red and Arlansas Rivers, and in the Yazoo River would help control the area. 55 carroll passed along his comments to the war Department. sometimes she credited him, as in one letter to stanton in which she praised scott's "incalculable service" and requested stanton to promote him to the surveyorinip of New orleans (a post for which scott may have been gualified but hardly would have wanted. 56 sometimes she did not credit him, as with the Hovember 30 letter that first set out the rennessee Dlan, and in the letters to Iincoln in which she first vrote of her sping as a gtrategise in developing that plan. The cordial zelationship Carroll and scott enjoyed may have been whe grept carroll from pushing herself too strongly as sole author of the plan. While the two letters she wrote to Iincoln in late June and early July 1862 made no mention of scott as the the source of her information, a gafe asamption might also be that Incoln was never read the second hal of the letter wherein carroling clalm as s016 strategist was daid out. A Incoln angry at carrol1's proposition to be pade \$50,000 Lor her literary services was not a man to be given ar additionel bind for wtrategic services rendered. Carroll gutte possibly might have stopped her reading at Iincoln's evaluation of her demand as 
"outrageous" and left his presence. Hot-tempered as she was, she was politically prudent enough to know when to retreat temporarily from an unpopular cause. As for scott, he made no mention of feeling slighted (if he knew of her atterpts and expressed no desire to be pald for his services as a strategist.

Carroll had also written to colonel scott and to John Tucker in the War Department in the spring and summer of 1862 , seelsing payment for her pamphlets, and none of the letters that survive mention her military claim; her demands are for payment "for time, labor and means expended" in producing her pamphlets. 57 Given Iincoln's reaction to hex Iiterary Gaims, Carroll probably simply decided she would be pushing her lucls to demand payment for a plan of military strategy. Being a civilian and woman would guarantee her little support whould she choose to stake such a clain, paticularly without Ifincoln's support, and particularly if she chose to ignore scott's role, since she had already mentioned his wors to the war Dayartment. Thus, in a letter to gtantor in septerber, she made no mention of her strategy of the previous year, but instead concentrated on her pawt pamphlets and on future sales: "I believe in my woris on the war Powers of this government I was the first writer who succeeded in placing the power of the government to majre arrests for politicel offenses and to suspend the mrit or Haban corpus on its true foundation! This claim 
to premiership, carroll argued, not only should be liberally rewarded, but she would be pleased to expand the circulation of The War Powers, or, "better still . . write a new paper, specially on the powers of the Executive to suspend the writ. . . and to arrest political offenders." 58

Colonel scott, responsible for carroll's monetary predicament, was still avolding her in october of 1862 . "If I had known where to find you, "he wrote her after she had tracised him down in Philadelphia, he would have called. He was "gratified" to Learn that her pamphlets had been deemed useful to the cause, and he "sincerely" hoped "that you will be able through $7 \mathrm{~g}$. Tucker to finally arrange your matters with the department. "59 Her financial status had also worsened by this time with the collapse of her coloniation plans with A. C. Burr for the Lincoln Colony in British Honduras. But in spite of her tentative attempt to bill the government for her military strategy, and ins spite of bew straitened finaneas, carrol1 weens to have thought better of making her claim an issue. By the end of the war, in fact, she mrote a letter praiging captain Scott' work, deeming it "a pleasant duty to maks known to the American people how mah they are indebted to captain Charles crowning victory which now thrills with joy every patriot. .

when the histery shal be correctly written it will be obliged to treat the carapagr up the Tennessee River 


\begin{abstract}
as the turning point which decided the triumph of the union over treason and rebellion, and that this campaign was the result of the information herewith submitted [by scott] was fully confirmed

by . - Thomas A. Scott, Assistant secretary of War, to whom the country is incalfulably indebted for inaugurating the movement." 60
\end{abstract}

This letter of Carroll's in the National

Inteligencer not only recognized charles scott's hand in developing the plan, but also (nistakenly) credited Thonas scott with the plan's implementation because of his trip west shortly after she sent the plan to the war Department. A gracious gesture by carrol1, or so it seemed. But in 1876, when Carroll and charles scott faced each other in a Congressional hearing or her claim to be the sole author of the Tennessee Campaign, Carrol':s gracious attempt to give credit where credit was assumed due began to acquire a distinct odor of deviousness. 61

According to his testimony before the House Comittee on Military Affairs in 1876, scott had appeared in washington a day or so before the letter praiging him was printed. Ho had come to asf for help from General Grant or anyone else with influence to help him obtain relief from a 25 pex cent duty on 1,000 bales of cotton. Scott had lost money in the war: he had worlad for a lower malary to serve the Union, and, Finen capturea by Genezal Pillow in the sumer of 1861 . he nel received certidicate of valvation for his steamer that his paxtrers had traded for cotton. If he conda get the cottor through the Iines and se11 it 
duty-free, he decided, that would even things up. 62 He wrote to Carroll and called on her and Lemuel. Evans, two persons who had no doubt given him the impression they had considerable influence with various high-ranking officials in Fashington. There with Carrol1, Evans wrote out a permit, scott testified, that gave him permission to bring In 10,000 bales duty-free. Scott handed it back, but Irvans assured him that "everybody else vas doing it and proposed that I should give him an Interest in it: half of the profit from the extra 9,000 bales would go to Evans-and half of that to carrod. Scott refused the permit "in toto" and left. 63

A few days later, the letter signed by carroll praising scott appeared in the National Intelligencer. The author' motivation might have been the highly noble one of honest praise. More Iirely, though, it was an attempt to bribe scott with recognition in hopes of getting him to return for the 10,000 male permit or, at the least, to keep him Srom dischosing Evans' dishcnesty. Apparenty the article attracted Scott's attention, for the three net again. Carrol1, Scoti aaid, "began to sort soep me," telling him that she and Judge Evans had writter the article so they could garner public support for a cain to congrass. They wonld "engineer it through" in Scott" name, and scot mould divide the proceeds with them. "I told them I had onIy done any duty and all I asked was the privilege of 
bringing in my cotton. . . "64 The "thing dropped right there" and scott returned to the west. His cotton claim was lost in the shuffle of bureaucracy. 65

Carroll's version of the circumstances which had prompted her generous letter was a bit different. She granted that scott had come to washington for help in securing his cotton, worth about $\$ 30,000$. scott, she said, had offered her one-fourth of the $\$ 30,000$ for her help, which consisted of her going to the Treasury Department and sending him the regulations. She then wrote him that "when he complied with them he could get his cotton without tax."66 She asked for nothing and received nothing for her aid. As for the article in the National Intelligencer, Carroll had not even written it: Lemuel Evans had. And scott had paid the paper $\$ 35.00$ to guarantee its

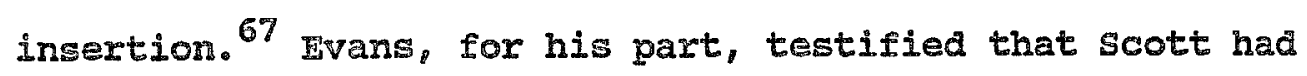
asised him for a permit for the cotton pthis in spite of Carroll's assertion monents earlier that "no papers were dram: none were needed," and in spite of her Ietter to scoti in which she told him she had sent him the "authority" he needed). Evans adimitted that he "may have suggested the form lor his application" but that would have been only to Carrol1 and would be $"$ iss her handwriting." As for the article, it was written "not only to do captain scott justice, but also to give him prominence and standing, as he complained of injustice having been done him." 68 
Scott's sense of injustice had been building for a long time. of 128 st. Louis and New orleans pilots, he had been one of only five Union men. He had had to take a pay cut during the war fron $\$ 300$ to $\$ 250$ per month. ${ }^{69}$ After the war, when he tried to return to work as a pilot, he had had trouble getting work: "a steamboat agent in New orleans told me he would not ship freight on a boat that I was connected with, and would use his best influence to prevent others also.170 He had lost his steamer to the confederates, had lost inis cotton that was the steamer's exchange, and had lost his temper when he discovered in the late 1860 s that Carroll had begun promoting herself as "Claimant for remuneration for originating the Tennessee campaign. 171

By 1872, Carrol1's claim had acquired newspaper support, congressional support, and pamphlet support. Apparently, scott decided to try his luck before congress as we11. Carroll had failed hirm the thanked her for trying to find him a position-she did not succeed), but hit overall motive was not revenge. ${ }^{72} \mathrm{gs}$ their mutul acquaintance I. S. Mecoy wrote CarrolI, Scott was after money. He had "Iittle faith ins the generosity of claim grants," or whether his petition would work, but financial woes and a pushy grother-in-Iaw (a "Mx. Fish") had convinced him to take his claim to the government. Fe "would prefer to have your \& the Judge's [Ivans] cooperation if it can be conveniently 
had," wrote Mccoy, 73 and scott reassured Carroll that "I do not believe that I will injure your claim, but rather strengthen it. . . If you like the idea I think you can make more out of it (nny claim) than you can out of your own, ${ }^{74}$ presumably referring to the three-way split Evans had allegedly offered in 1865 .

scott underestimated Carroll's ability to make something momentous out of something miniscule, however. By 1876, while scott' claim had gone nowhere, Carroll had turned her original $\$ 5,000$ clain into a request for $\$ 250,000$ "es compensation for originating the Tennessee campaign."75 carroll faced an angry and embittered scott in that congressional hearing and won hands down. Both Carroll' ${ }^{\circ}$ and scott' claims to be the authors of the Temessee campaign rest primarily on dircumstantal evidence. While carroll would continue to build on her whaky foundations until her elaborate tale nid Its guestionable core, scott retired from the fray. only in 1889 was he again ariven to mage public his part in the Tennessee campaign, when he published a pamphlet regardino Carroll"g "FraduIent" [sic] clajm. He deemed it his duty, he wrote in his introduction, "to prevent this rald on the Treasury that I an sure is being prepared for during the present administration.176 scott included selected portions of the House Docunent that had been pubished after the 1876 nearing, Ietters of endormement POr his "valuable 
information" from both Gxant and Acting Rear Admiral

S. P. Lee in support of his contention that the strategy was his rather than Carroll's, and a letter in which he had promised carroll that if she did not desist in her claim, he would "take means to explode it."77 To make his position appear as disinterested as posslble, scott even included a petition "gotten up by my steamboat friends" some years earlier that had requested a pension for bim for his invention of a signal system used by passing boats, a "BOIIJER IRON PROTECTOR" he had invented, and for his "valuable information to those in charge of the I'ennessee Campajgr." The pension request had "died a netural death" and scott swore he had had no part in getting it up. Moreover, he had only mentioned it before the hearing "to show the gtanding in which I have been beld.978 In fact, Scott had told the House compttes that wile he had not come before them "expecting pay for doing ryy duty as a loyal man," justice demanded that he should be given credit as the the campaign's originator, "and if your honorable body thinds that any compensation is are the authow, I laim that that compensetion is due to your petitioner. 70

As far as scott, 想vans, Carroll and the cotton claim were concerned, scott printeo only his version of events in his pamphlet, but with cazzoli"s history or selfopuryexy. pretensions to influence and the IIngering arome of con-artistry that survivad from hex days in New Yors, 
Scott's accusations ring true. Given Carroll's constant need of money, if scott's offer of one-fourth the value of the cotton (\$7500) for her help had been made, as she claimed it had, she would have taken it. since she swore she did not, "nor did I ever think it worth while to inguire, "the greedier version of scott's claim that Evans had offered to obtain a tax exemption for him in exchange for a half share of the prosits to split with carroll certainly seems more Iirely. 80

There is no grestion that both scott and carroll had an egual share in developing what they calied their "Tennessee campaign." Scott was an experienced pilot and a strong unionist who took every opgortunity to help the war effort. No doubt he did discuss the western waterways with Grant or other union men. and carroll aid have enough access to colonel Scott in the far Department to present the weI I writter and strategically sound plan she, scott, and Evars had developed, as well as enough initiatige to mrite to Stanton and Incoln to pass along Scott's intormation and tel1 them how to run the war. But as far as elther one of them materdaliy affecting the outcone of the bar by the submission of the "Tensessee campaign Plan" both strateglsts were too late in their actions. General crant made that cleas In a letter to his friend, Representative Eling B. Washburme: 
I see the credit of attacking the enemy by the way of the Tennessee and cumberland is variously attributed! It is little to talk about it being the great wisdom of any cen. that first brought forth this plan of attack.

our gunboats were running up the Ten and cumberland rivers a11 fall and winter watching the progress of the rebels on these worls. Gen. Falleck no doubt thought of this route long ago and $I$ an shure [sic] I aid.

The Union leaders hrew of the importance of the Tennessee and cumberland Rivers. The confederates had built Forts Fenry and Donelson because of the strategie importance of those rivers. The army knew their importance, the navy knew their importance, wen the New Rork Times had printed a letter that not only detalied the importance of the rivers as altemate routes to the mississippi, but mentioned the possibility or cutting the Charleston and remphis Railroad by going up those 31vers. That letter was published berore Gargoll had even returned to pashington in late Novanbar 1861. As for her coments regarding the importance of

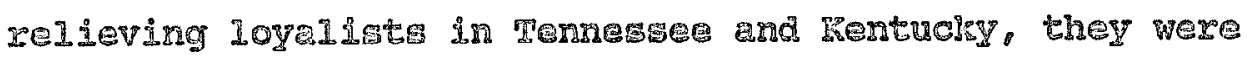
hardy original either. IIncoln was well aware of the Importane of those areas to the Union cause by saptembar 1861. Simply gut, given the time constraints within which Carroll and scott both placed their actons, neither one can be taren sexionsiy by miltary historieng as unsung heroes who had saved the unjon by their brilliant strategy. 32

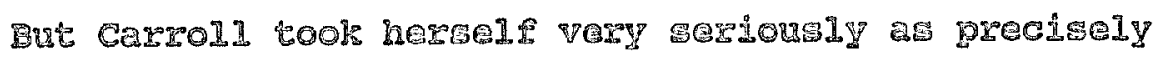
sucin a flguge. ODsEssed with a desire 
payment, once again twisting and turning the truth till it bent to fit her perception of it, Carroll sought the recognition by the world of her claim. From the fall of Forts Henry and Donelson in February 1862 until her death thirty-two years later, carroll's other interests gradually faded away until her desire for recognition became her consuming passion. 


\section{Notes}

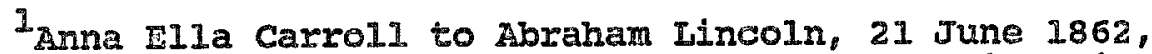
2 July 1862, Anne Illa Carroll Papers, Maryland Iflstorical Society, Baltimore, Maryland. These are drafts of the same letter with two different dates on it. There is no corroborative evidence that carroli and Iincoln net, but since carroll later gruoted Iincoln's remark in a letter, no doubt the meeting took place. see n. 40 below.

${ }^{2}$ Lemuel D. Fvans to willian Fenry seward, 7 september 1861, Carroli Papers.

3anna EII Camroll, "Plan of the Tennssse Campaign," North American Review 42 (April 1886):344.

Ibia., pP. $343-344$ 。

5BId., 8.34 .

6.R. Shattudr, "Anua Ella Carro11: The originator of the remessee campaign " outing 6 (JuIy 2885): A07.

7 Marvir R. Cein, IJncoln's Attomey Ceneral: Edrara Bates of Missouri (Columbia, Missouri: Univexsity of Missouri Press, 1965), po. 137-138.

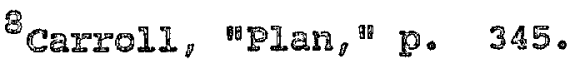

Tbia.

10 Carrol1 was mistaken when she talked or a Memphis \&

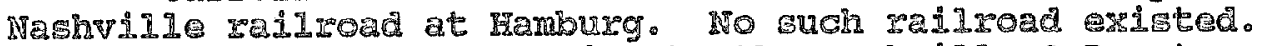
She wes most Iijeely referring to the reshvid1e \& Decatur Railroad, futine to the omst. The original text of Carro11' plan was reprinted a number of times. Each version hes rasnor changes in the text, but they are all virtuliy identical. There is one vezsion, In whet is presumebiy the hand of a professional amanuensis, in

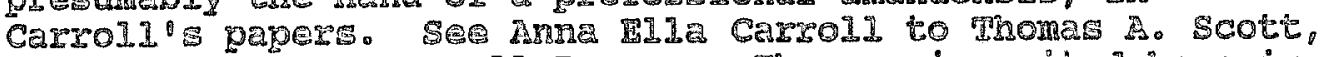
10 Tanuary 1862, carroll Papers. The version aited here is Erom Charlog a scots, The Oxigin of the Tennessee Campaidn,

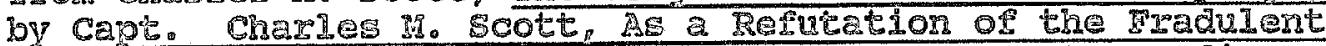
Clein of Miss Amme 21 Ta Carrol1 [sic] (Terre Haute, Indiana: Moore \& Langen, 1889/, $99.12-14$. 
${ }^{11}$ Carroll, "Plan," p. 345.

${ }^{12}$ shattuck, "Anna Ella Carrol1," pp. 406, 407; carroll, "Plan," p. 347.

13 [Lemuel D. Evans], The Material Bearing of the Tennessee Campaign in 1862 upon the Destinies of our Civil War (Washington, DC: W. H. Moore, n.d. [Circa 1872]) lists the effects of the plan's strategy mosi comprehensively. See 2150 shattuck, "Anna Ella Carrol1" and Carrol., "PIan," as we11 as the entry for Carroll in the National Cyclopedia of American Biography 62 vols. (New york: James T. White \& C0., 1893-1984), 5(1984):193.

${ }^{14}$ Shattuck, "Anna Ella Carro11," p. 409. Iincoln's reaction is given in varions words. This is the most dramatic, and was talsen from an interview conducted with Carroll late in her life. since carroll did not meet rith Iincoln regarding the plan, and no direct evidence of Inincoln's reaction survives, all guotations of this kind can be regarded as poetical in nature.

$15^{\prime 2}$ Incoln'G Lady Strategist," Life 25 (26 July 1943):101-102: Marforie Barstow Greenbie, My Dear Lady: The Story of Amna Bla Canrol1 the "Great Unrecognized Member of Iincoin's Cabinet" (J⿸W Pork: McGraw Hill, 19,0).

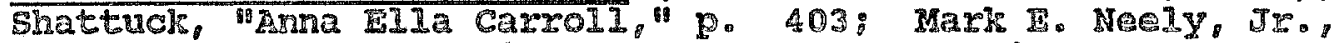

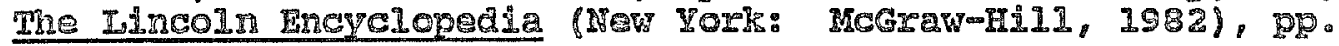
$48-49$.

16 whe war of the RebeIIion: A Compilation of the official Records of the Undon ard Confederate Armices 70

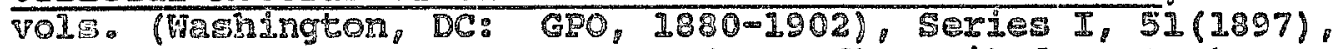
pt. 1, pp. 369-370: 366-387. (Hereafter cited as OR.)

$$
17 \text { Tirgil Carringtor Jones, The Civil war at sea } 3
$$

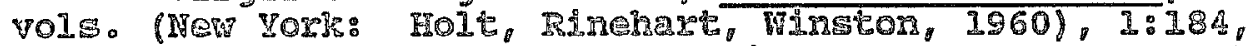

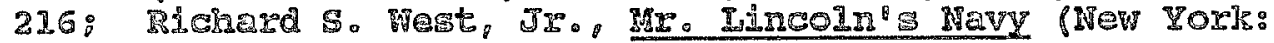
Longmans, Green \& Co., 1257$)$, pP. 158-161.

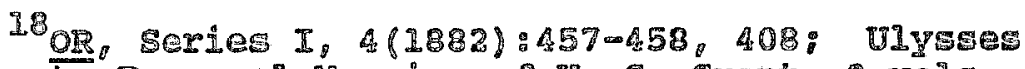

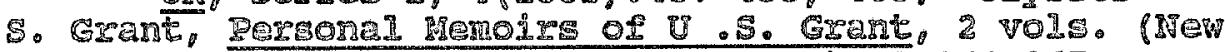

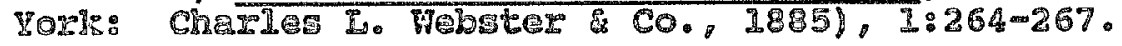

$$
\begin{aligned}
& \text { 19oR, Seztes I, 4:456, 457-A58, 456, 459-462。 } \\
& \text { 20IbIa. Pr. 345-346: Bern Andermon, By Sea and By }
\end{aligned}
$$

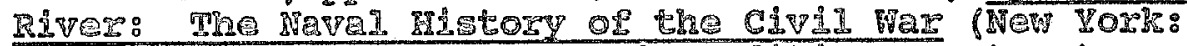


letter to Halleck suggested that a joint land and water move up the cumberland and Tennessee Rivers, "the most passable route into Tennessee," would threaten Confederates at columbus, force Confederate General Buckner to retreat, and provide a water route halfway to Nashville, thus pushing the confederates out of Tennessee. The letter was dated 20 November 1861. OR, Series I, 7:440.

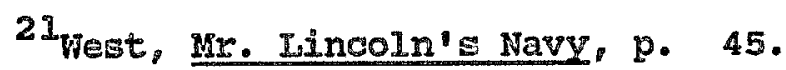

22 Civil War Naval Chronology 1861-1865, compiled by the U. S. Naval Department, Naval History Division

(Washington, DC: GPO, 1971), P. 14; Afred T. Mahan, The Gulf and Inland waters (New Yoxk: Charles Scribnex's sons, 1883 \% po 12. Missouri was added to the Department of the Ohio 6 Jume 1861; the western Department was constituted 3 IuIy 1861, made up of IIIinois and all states west of the Ihississippi River to the Rocly Mountains. See Mary

M. Boatner, III, Civil war Dictionary (New York: Maray Co., 1959), pp. 606, 903.

23 Official Records of the union and Confederate Navies in the War of the Rebellion, 27 vols. (Washington, DC: GPO, 1894-1917), Series I, 22(1908):279. (Hereafter cited as ORY.

24 Maha, GuIf and InIand Waters, p. 13.

25 ORN, Ser1es I, 28:284-205, 195, 277, 307-308.

26 Grant, Mgenoirs, 1:264: Kahan, Gulf and InIand Waters: 9.16 .

27 ORN, SERLำ I, 22:355-356,369,375, 378: Mahan, GuIR and Indand Waters. 2. 16.

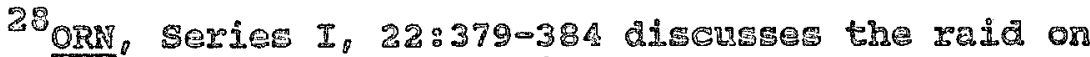
Fdays II on the Cumberiand River, $26-28$ october 1861. The sald or Belmont of Novenber 1861 on the Mississippi River.

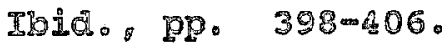

29.10. p. 388-389.

30. G. RandaI1 End David Donald, The Civil Fax and Reconstruction, 2 a ed. (Ierington, Hassachusett: D.C. Heath \& CO. 1969), pp. 371-372.

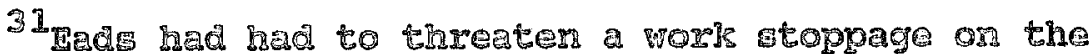
IrOn-G1 Series I, 22:378. E。 B. Long polnted ont the difficulties 
in the Western Department in "Anna Ella Carroll: Exaggerated Heroine?" Civil War Times Illustrated 14 (July 1975):33-35. For correspondence of Grant and Foote with Halleck and the reports on the capture of Fort Henry, see OR, Series $I, 7: 119-416$. See also Bruce catton, Terrible Swift Sword (New York: Doubleday, 1963), pp. 141-142, $146-147$.

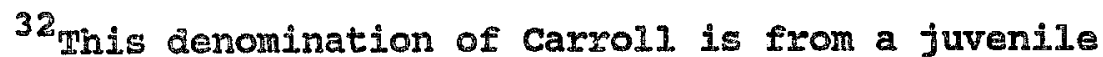
biography: Winifred $\mathrm{F}$. Wise, Lincoln's Secret Weapon (New Yoxk: chilton Co. 1961).

${ }^{33}$ Amna E1la Carroll to Abraham Limcoln, 21 Iune 1862, carroll Papers.

34 See Ama E112 Carro11, Clam against Government, october-November 1861, MDES 3650-176, Carroll papers.

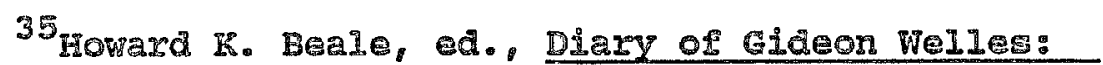
Secretary of the Navy under Lincoln and Johnson, 3 volg. (New York: W. W. Norton, Ino. 1960), 1:127. mile aderyate as an employee in the War Department, scott had alsc continued his position, unpaid, as the vice-President of the Dennsylvania Railroad. The railroad obtained a number of lucrative contracts from the govemment ouring Scott's tenure. See Burton I. Fendrigk. Incoln's War cabinet (Boston: Little, Brown Co.s 1946), pp. 220-221.

36 Thomas 2. Scott, statement dated 28 Ianuary 1863, Gited in Serah Elien Blackwel1, Iffe of a Military Genius:

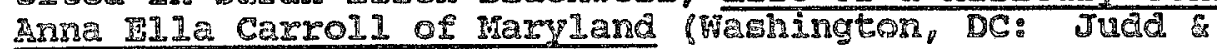

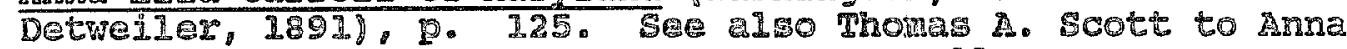
EIla Carrol1 [?], 2-28 January 1863, Carrold Papers.

37. Mna IIA Carro11, Clain against Goverment. 2 January 1863, IRDE 3650-183, Carrol1 Papers.

38 Anna pla Caxro11 to Aoreham Incoln. 21 Jure and 2 JuIy 1862, Carro11. Bapers. The fingts of these two letters is obviously a draft: the second is an incomplete copy of the firgt, but does contain a notation by carroll that $1 t$ was read to Iincoln, presumaly about JuIy 2.

39 Anna FII CarrolI to Tohn Tucker, 26 March $1862_{8}$

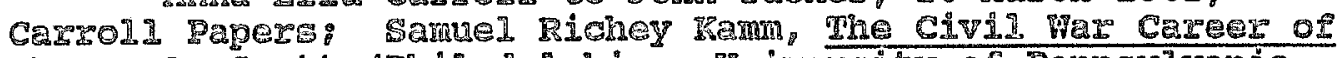
Thomas A. Scott phidadelphie: university of Penseylvania, $19401 \% \mathrm{PD} .35086$.

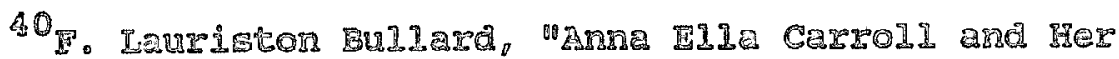

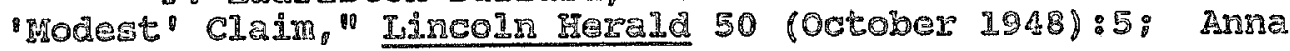


Ella Carroll to Abraham Iincoln, 14 August 1862, Dbraham Iincoln Papers, Library of Congress, Washington, DC (microfilm).

${ }^{41}$ see, for example, Bullard, "Anna Ella Carroll and Her 'Modest' Claim": E .B. Long, "Anna Ella Carroll: Exaggerated Heroine?" Pp. 28-35; Kenneth P. Wililams, "The Tennessee River Campaign and Anna mlla Carrol1," Indiana Magazine of History 46 (September 1950):221-248.

${ }^{42}$ Scott, Origin, pp. $6 \mathrm{~m}$.

${ }^{43} \mathrm{~V}$. S. Grant to Captain Scott, 18 March 1865 and U. S. Grant to Board of Inspectors, 15 Apri1 1862, both cited in scott, origin, D. 29. Neither of these letters appears in crant's papers. See 2150 scott, orioin, p. 7.

44 Elias Jones, Revised History of Dorchester County, Maryland (Baltimore: Read-Taylor Press, 1925), p. 297; Greenbie, My Dear Lady, p. 132.

45 scott, origin, p. 8.

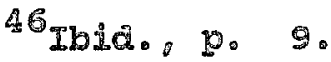

47 Tbid.

${ }^{48}$ Charles M. Scott to Anna Scott, 4 February 1862, Carroll Papers.

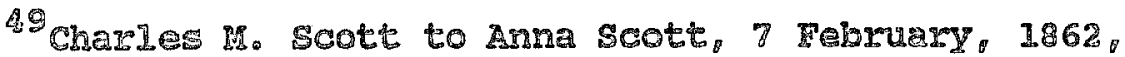
Carzol1 Papers.

50 E. A. Scott to Arma F1Da Carro11, 24 Merch 1862, Carroll Papars.

51. A. Scott to Mnna E11a Carro11, 25 May 1862. Cazroll gapers.

52 Charles M. Scott to Frank I.Blaix, 31 May 1862, Carrol1 Papers.

53 Chardes M. Scote to Anna Ella Carrol1, 9 IuIy 1862, Carrol1 Papers.

54 Charles M. Scott to Ama FII Carroll, 2 May 1862, Carrol1 Papers; williams " "The Terressee River Camaign," P. 245.

55 IbId. See aIso Charieg M. Scote, Extract: 23 
March 1862 through 7 June 1863, MDHS 3650-202, Carroll Papers.

${ }^{56}$ Anna Ella Carroll to Edwin Stanton, 14 May 1862, Carroll Papers and Anna Ella Carroll Papers, Carroll, Craddoek, Jensen Collection, Maryland Historical Society, Baltimore, Maryland. (Hereafter cited as CCJ Collection.)

57 Anna Ella Carroll to Jchn Tucker, 26 March 1862, Caxyoll Papers: Anna Ella Carroll to Thomas A. Seott, 7 June 1862, Carroll Papers: Anna Ella Carroll to John Tucker, 30 June 1862, Carroll Papers.

$58_{\text {Anna }}$ Ella carroll to Edwin stanton, 9 september 1862, Carroll Papers, CCJ collection.

59 Thomas A. scott to Anna File Carrol1, 27 october 1862, Carrol1 Dapers.

60 Anna Ella Carrol1, (Washington) National Intelligencer, 12 Apri1 1865.

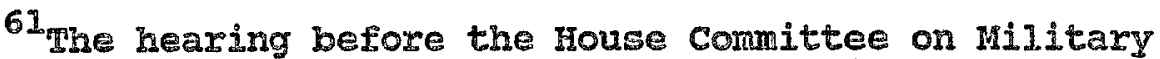
Affairs was held II JuIy 1876. The proceedings were the following August. U.S. Congress, House, committe on Pilitary Affairs, Petition of Anna RIIa carroll for Compensation for services Renderea to the War Departinent during the Late Was, 4 th Cong. Ist sess. 1876. F. Mis. DOC. 179. (Mereafter aited as HR DOC. 179.)

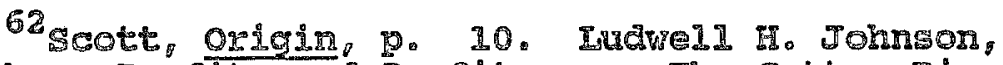
"Mortherg Profits and Profiteers: The cotton Rings of

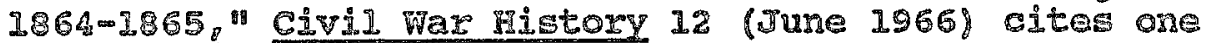
inetance in october 1864 where 1500 bales of cotton was wOrth worth about $\$ 650,000$. Of course the price of cotton, as with ald cormodities, varied greatly year to year. Presuably that figure would be a gross xather than net worth, mithout acconnting for the costs of transportation, taxes and bribary of army and government officials for

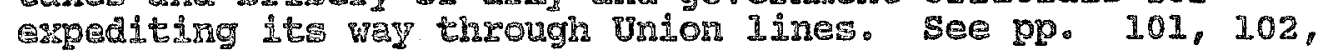
106,1240

63 Scote, ordgin, p. 19.

64 Tia.

65 Scott claimed he Left caxroll:; and found General Grant, who toom him to ses lisscoln on whe very day" of his death. Iningaln took nis papers and promised hin a permit if 
they were in order. Scott had run out of money and had to leave Washington that evening. He heard of the President's death at Harrisburg the next day. His papers were never founa. see scott, origin, pp. 19-20. There is no corroborative evidence for scott's statements. Iincoln did see Grant that day, but there is no mention of scott then, or at any time in the previous few weeks. Farl schenck Hiers, ed. Iincoln Day By Day, E Chronology 1809-1865, 3 vols. Washington, DC: Iincoln Sesquecentennial Commission, 1960), 3:320-330.

$66_{\mathrm{HR}}$ DOC. $179, \mathrm{p} .11$.

67 Ibid. p. 12. Carrold's claim that seott paid to have the lester inserted was probably false. The letter was puinte under the neading "Voluntary communication." Such items were solicited and paid for by the Mational

Inteligencer. See front page, Wational Intelligencer, 12 April 1865 ard any issue.

68 ERR DOC. 279, PP. 11, 30,31.

69 Ibia.. po 115 .

$70_{\text {IB. }}$ ide. $\mathrm{p}$. 17 .

71 Ibia, p. 122 .

"72 [Evans]. Material Bearing: letter to editor cited

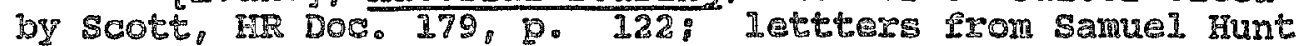
to Anna FIJ Cerrol1 throughout 1871 and 1872 in the carro11 Papera, CG Callection. Scott wished Carroll good luck on her elaim and expressed his gratitude for her patronage search on $\mathrm{sis}$ behalf in Charles Casro11, 1. January 2870, Carro11 Papers.

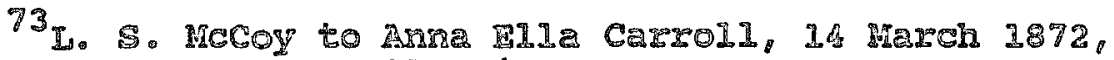
carroll Papers, CCT Collection.

74 Charles Me Sctt to Anna IIIa Carrol1. 14 March 1872, cited III HR DoG. 179, D。 116.

75 Ib1ำ. 2. 221.

76 geott, orioin, p. 3.

77. S. Grant to cantain Scott, 18 harch 1865,

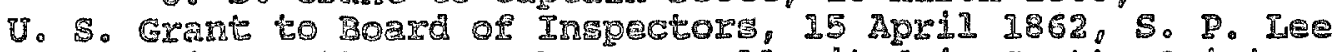

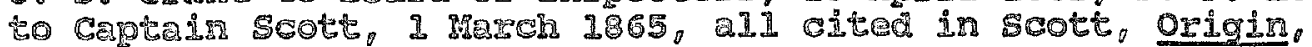
20. $29,30,31$. 
${ }^{78}$ Ibid., p. 37.

${ }^{79}$ HR DOC. 179, p. 122 .

${ }^{80}$ Carroll had warned scott not to breathe a word of his business in cotton, "for the reason that the Treasury Department gives all its instructions secretly and they do this to cut off all illicit trade." Anna Ella carrol1 to Charles 1. Scott, n.d., reprinted in HR Doc. 179, p. 30. see also scott, origin, p. 26.

81. S. Grant to Elinu B. Washburne, 22 March 1862, The Paper: of Ulysses $S$. Grant, 14 vols. (Carbondale, IIIinois: Southerr IIInois University Press, 1967- $)^{\prime}$ A:409: see also Bruce Catton, Grant Moves South (Boston: Ijttle, Brown \& Co. 1960), pg. 123-126.

82 Two letter: in the New Yorj Times detail the same strategic importance of the rivers, including mention of their navigability and their closeness to the Memphis \& Charleston Railsoad. See Correspondence signed "yennessean, Hew Yor] Times, 17 November 1861 [the most complete of the two of the strategy and remarkably similar in information content to Carroll'g planj and 21 December 1861. The author of the axticles reported giving the information to a loyal gentleman of some military experiance in June 1861. For Iincoln's vieve on the importance of relieving Unioniste in the Border states, see Roy P. Bariex, ed. The Collected Wors. of Abraham IIncoln,

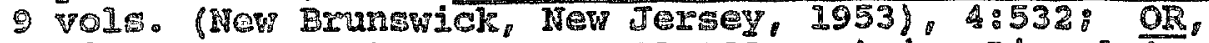
Series $I_{p} 52$ : pt. $I_{\text {, }}$ p. 191-192 contains Iincoln overaIl plin regarding the western Theatre. It is not dated, but was writter p1010 to 5 ostober 1861. See Chapter 7 below for the conclusions of civil was historians such as renneth wiliams and $\mathrm{F}$. B. Long regarding Carroll's claim. 


\section{Chapter 6}

\section{The Search for Vinaication}

Gratified by the success of the federal armies in the western theatre moving in apparent response to her plan, Anne Carroli continued to make suggestions of military strategy to the war Department in the spring of 1862 . On May 2 , whe gave the goverment information charles scott had sent her that slsiffs and canoes were being sent to the Yazoo River. Fearing that confederates would flee down the Yazoo to the mississippi and thence to Texas and sexico, scott suggested the yazoo be watched with federal gunboats. on May IA, Carrold mrote again, reiterating scott'g coments on the necessity of guarding the Yazoo and recommending the occupation of Viclswburg General Henry He1lect was creeping toward Corinth, and the "Impending battle in North Misgissippi" would force the enemy to retreat to vidksburg, she reasoned, so they could cake the railroad froxi there to escape Into Texa: ${ }^{2}$ 
Carroli's continued assumption that the Confederates would be driven west of the Mississippi rather than retreating south from corinth by either the Tombigbee River or the Nobile \& Ohio Railroad, might have been due to the influence of her Texan friend, Lemuel Evans. Evans is an important but shadowy figure in carroll's history. They had met when he took office as an American Party congressmars in 1855: they had travelled together to st. Louis in october 1861. They corresponded frequenty when separated from each other. Unfortunately, only a few of Evans " letters survive in Carroll's papers. Though she remained "Miss Carroll" to nir until his death in 1877, the nineteenth-century formality did not uide the intimacy of their friendship. Whether there vas an adaícional tie is aifficult to judge. CarroI had once told Thumlow weed that she would go to Wexico with Trans if he was appointed Minister. ${ }^{2}$ Her journey with him to st. Louds was apparenty with no other companion or chaperone, but that was not unheard of even in she carly days of the wag. ${ }^{3}$ she travelled with nim to

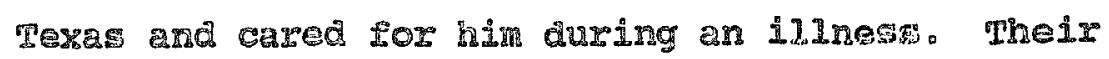
reletionship, although very close, was palic anough for her to discuss him with her ramily, Including her father and for formar senator fron comecticut Trman Smith to tease Evans to "give my love to Nigs carrold if you dare! s" Tither carsoln presumed her age and her kmow polibical activities would protect her from gossip regarding Evan, or 
she did nok care what rwwors flew. She had found a man who shared hex political views, who championed her cause, and who probably helped assuage hex pain at the death of John Causin.

By Ifarch 1862, Evans returned to washington where he remained near carrol I for most of the rest of the war. Fe had discovered that the union had no plans to attack Texas, and being thus "satisfied that I can no longer render adecuate service, "he had resigned his state Department Comission of the provious August. 5 Carroll continued to myite gor the war effort, but hex attempts to contribute were soon rejected. Mithough Evans told the new secretary of war Stanton that an agreenent had existed between Carrol I and the War Department, Fhomas Scott had left Jure 1. 1862. and carroll row aealt with Assistant secretary peter

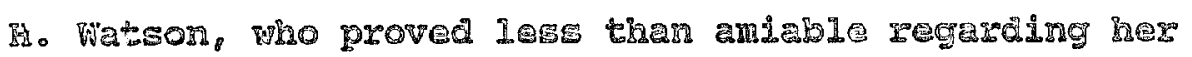
1deas. ${ }^{6}$ In JuIy and August she resubmitced her bII 101 55,000 101 mork anready done: on septenber 9, Hhe sugested another pamplet for the Department's conadderatzon. In January 1863, she झubitted her bill again, this time aajusted ugware. to $\$ 6,250$, notirg that Thonas scott had

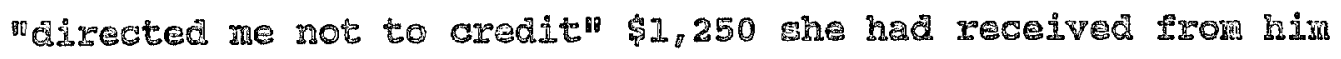
since he had pasd that out of his pocket and when the whole

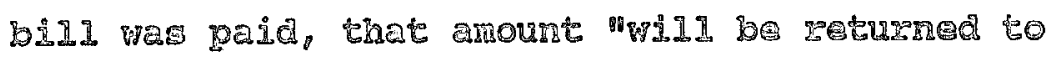
Col. Scott. 1

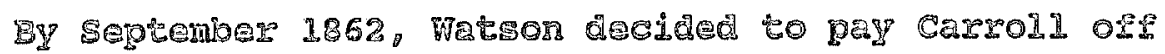


by giving her $\$ 750$ as "reasonable compensation . . for the public service" she had rendered. Carroll took the money and signed receipt as a payment "in full for the above account and of all demands against the United states government." Watson no doubt considered the case closed. but Carrol1, having found a source of incone that enabled ber to purtue her favorite activities of writing and politicing, interpreted watson's payment not as a way to end her importurities but as a confimation that the oral agreement she had made with scott was still in force. Accondingly, when carrol 1 wrote another pamphlet on the rights of bhe sececied states and submitted it to the department, she no doubt erpected a conthuation of the account.

men Carrol I followed up her pamphet with another Ietter thet, handmeIIverad, suggested a papar on emancipation, watwon her had cnongh. While he had been WIIIro to pey at least a part OA Carroll's bi11, she ras * 9 m. employ you to mplte for this Dapartment or to compensate you

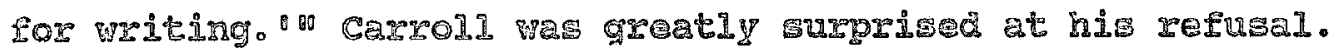
Watson, whe insisted, had asked her to cald. Now, she mpote, if he vould simply do his duty and Lay her Ldess berore Iis. Stanton, "II annot doubt that, conge the

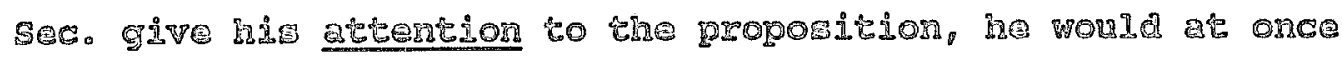

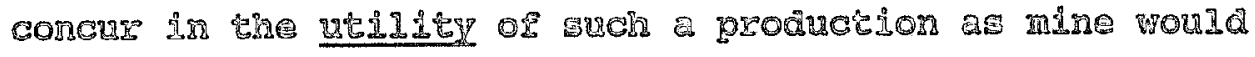


be." 10 In a frigid reply to her request, and "to avoid all misunderstanding and all necessity for further correspondence on this topic," Watson wrote, he was "authorized to state that the Secretary of War has never employed a public miter, on any subjert whatever, and the department accordingly camot avail itself or yours

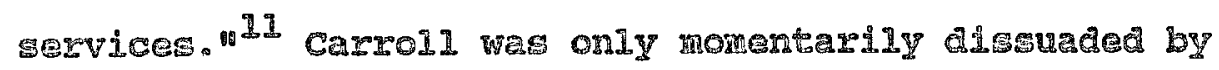
this idy dismissa: she wowld take up her cause again late that year. In the meantine, though, the presidential election captuzed her attention.

Carroll did not care much for Iincoln's polidies as president. His fallure, in her eyes, to follow her counsel regerding mancipation and colomination ma: a partciar sore point. As early as the offyear elections or 1862 she had becone certain thet it had "ever been the purpose of the President and the LeGton, mith wom he acts, to aboligh 5Iavery, in the entire south, and to restore the states upon

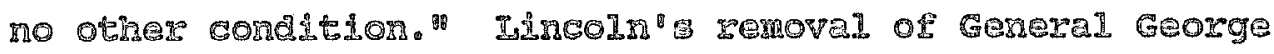
Mcclellan from the command of the tamy or the Botomac in the fall of 1862 , after IoCHellan failed to capitalize on the Undon wictory at Antietam by purawng the confederates, was. according to carral. Inncoln' way oto get the absolute control of the Army, for this express gurposen of exancipation by torce. 12 Although carrol1 hed maintained a cordial reIathonship with Lincon's Attorney General Bates and had included a pipe tor Incoln in a gite of tobacco 
pipes she sent to Bates, by 1864 she was convinced that Iincoln had to be defeated to save the country from a military despotism. 13

In June, Carroll attended the Repubilcan nominating convention in Baltimore: in August she went to the Democratic convention in Chicago. ${ }^{14}$ While whe would later mrite Salmon chase that she believed "an irreparable mistake was committed" when chase was passed over for the Republican nomination, For Carrol1, the Republican party was a 1ost cause regardhess of the nominee. ${ }^{15}$ The President, the Radicals, the momentary candidacy of John charles Fremont. all required the acceptance of the mancipation of slaves. Carroll wes convinced that the Republicans were too intransigent to compromise on the question of slavery. That intransigence would destroy the union if 1 prevaided in the upcoming election. 26

Fven though catro11 loa gexhaps begu to sense the inevitabi1ty of forced mancipation, taling chase mhe had "go gympathy with a dominant race, insolent \& oppressive, who violete ald the conditions ot liberty and then clain to be the authors of Ereearon, it is most 127 ly she wupported Democratic nominee George B. Mcolellan on his platform calling 2or the restoration of the union without regard to slavery. 17 The wasndngton Nationel Intel Iigencer, to which Carroll had contributed orer the years, supported Mcclellan LOr reasons of whlch carroll conla approve. Incoln's 
"despotic assumptions under the specious plea of 'military necessity" made clear Iincoln"s intention "to change the character of the war from the single object of upholding the Government to that of a direct interference with the domestic institutions of the states." Mcclellan, on the other hand, was a candidate "who promised to look with a single eye to the restoration the union under the Constitution, and would not "be jostled from nif purpose by extraneous InfIuences."18

The National Intelligencex reflected carrol 's opinione throughout the civil wax, and in November 2864 she wrote phurlow Weed, Fiward Bates, and Iemue Evans that its editor, colonel m11Lam the editorship of the papor. To Weed she esplained that Seaton woula be corced to shut dom if Inincoln mere re-lected, apparenty because of seaton's opposition to the

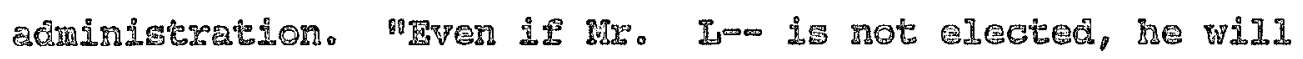
have to sell it all the same... talke part of the paper in a joint stock company to raise the necessary \$100,000 gurchase price. Seaton would give Cartol1 $\$ 20,000$ 02 that "to cary on the paper." "I have no earthIy doubt, "rhe vrote, "about my pover to conduct the editorial department ... I could make it a great lever \& I thing, with due modesty, you wi1 not alssent rmon this OPLIOS.

If พืeed replied, his answer did not murvive, but 
since he owned no part of the paper after seaton left, he obviously turned her down. 20 Edward Bates appreciated her "talents and acquirements" but cautioned that she might not understand "as fuIII as I do, the arduous labor required" to ruts the paper. 21 Evans, on the othex hand, urged carroll to accept. "I have thonght for some time tiat your vocathon is editorial." He wrote from chicago with the election results. Iincoln's remection, he thought, meant a "consolidated centraliged Degpotism," In which Washington City would become lifre the Rome of old. "Henceforth" he warned, "ald success depends on the ability to be . . . a part of the governing power. . or a flatterer of the govanng power " CarrolI could achleve that status more easily. Fvan thought, if she were editor of the Inicel 1igencer. 22

Is is true of many events in carroli' life, there

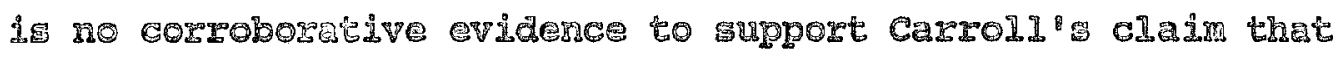

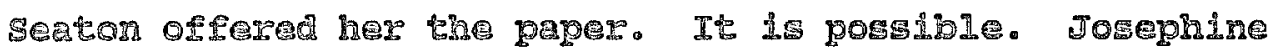
Seaton, the colonel' Eurviving daughter, thought enough of Carrol1": talents as a mriter to consider carefully her offer to rite his biography and to suggest that carroll edit a collection of her father"s letters or "political history or my rather ... or leaders or the Intelligencer, which would no doubt be velwable, and cajse. ${ }^{\text {23 }}$ mhe editorship seems a bit of a far-fetched proposition for Carall to have invented out of thin air. 
But if it was offered to her, it came to naught by December 1864. Seaton retired, a new editor took over, and carroll began to dun the War Department again to pay her claim. ${ }^{24}$ Times were hard for Carroll after the war, and she seratehed around trying to make a living. Keeping constant pressure on the war Department to pay her the rost of the noney she believed it owed her, she cut expenses by moving in with her brother Fenry in Baltimose and searched for other sources of income. She asked secretary of state 5อrard to send her on a tour of the Gouthern states "in some confidential capacity for the covt." in order to ascertain "their feelings, sentiments and aims" as the country moved toward reconcilidtion. 25 she moved back home with her father for a mort tlme and worked on a listory of the war, asting for reports from such primery sources as seward and Secretary of the Navy GIdeon WeIIes. 26 She filed a fomel. CIain with the war Department' ${ }^{-}$Board of Claims, stil making no mention of any work but her pamphlets, ard comvinged Thomas Scott to mârse har thought since "all she asks is but a mall matter. . if ander my contrel I should have no hesitation in allowing it. 27 she brierly 200ked for work as a teacher In New Yor: city and, per aver at the ready, contrined hes prewar aGtjvitdes of seeking patronage position for friends.28

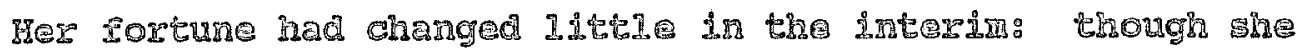

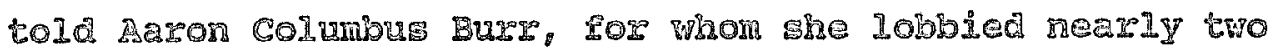


years for a post in Tripoli, that the senator she lobbied would "do anything" for her, "and he has," no appointment was forthcoming. 29 She also continued to write on the political questions of the dey and revised old articles for resale. 30

In the winter of $1868-1869$. Caxroll travelled to Tesag with Lemuel gvans to report on the Texas Constitutional convention, in which Evans tool part. She met the fanous ex-Spy Eelle Boyd on the boat from New OrIeans to Galveston and found her "just the bold forvard creature you may suppose . . aisgrsted every one... tallis of nothing but herselfwwhat great men she met. . acia $^{31}$ she wrote a Iong report on the Texas convention to Prosidento lect Grant, guggesting rexas be divided into several new states to "destroy the power of these old secessionists forever." ${ }^{32}$ Although Carroll Orighnaly planned to come back home as soon as the

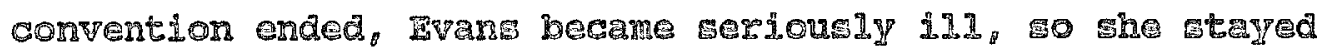
to care LOI him. "when he got alamed, she wrote her sister, "he proposed to turn over all his effects money to me at once" another indication of the irtimacy of their long relationship. Fortunately, Evans recovered. In the meantre, Carpol amused hermit during his recuperation

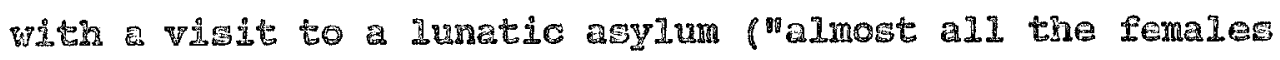

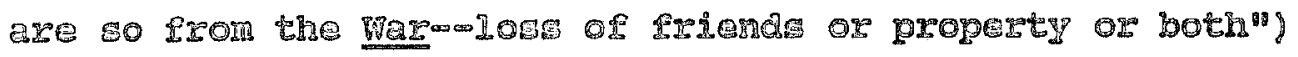
and enjoy 
But always in Carroll's life there was her claim. on May 10, 1869, Carroll withdrew all her papers from the War Department's files. on March 31, 1870, she petitioned the United states senate to award her "compensation cammensurate with the service" she had provided the goverment with her pemphIets which "communicated throughout tho stzuggle important facts and suggeations, and her military obsexvations which induced the government "to adopt the Tennessee River insteaa of the Rississippi... "

There are severel possible reasons why caroll chose to enter the public form with her claim instead of continuing her pleas and petitions to the War Depertment. Edwin Stanton, whom mhe believea had bean hept minformed of her clain and therefore had been mable to aid her, left office In 1868 and dided In Decenber of 1869.35 Recentlyelected Presidert Gart, whom she may have believed worla support her GIa in in order not to appear unchivalrous before his public, wes In position to hiold considerable power in per Bavor. Arad Benjamin Wade, retiring from the Senate to OnIo. hed watten her a letter.

I cannot take leave of publia Iife without ermoessing ny deep sense or your carvices to the country dur.ng the whole perdod of our national troubles. Elthough a citizer of a state almost unanimously disloyal and deeply sympathizing with secession, especially the wealthy cne aristocratich Gass of ner peopleto

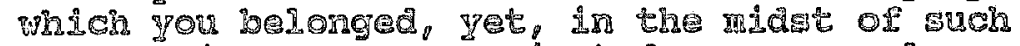
suzroundings, you enancipated your ows slaves at a great sacrifice or parsonet interest, and ris your powerful per derended the cerse of the 
loyalty as ably and effectively as it has ever yet been defended.

From my position on the committee of the conduct of the War I know that some of the most successful expeditions of the war were suggested by you, among which I might instance the expedition up the Tennessee River. . . I also know in what high estimation your services were held by President Iincoln: and I cannot leave this subject without sincerely hoping that the Government may yet confer on you some token of aeknowledgrment for all these services and sacrifices.

Wade would continue to write letters in favor of

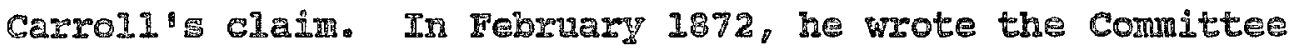
on IIIitary Affairs considering carroll's claim that President Iincoln "informed me that the merit of this plan was due to Miss carroll" and that "both kr. Iincoln and Mr. Stanton - - expressed to me their high appreciation of this : : Goverment would rebard her Idberally for the same - . . ${ }^{37}$ He repeated his praise of carrol $1^{\prime}$ 2ccomplishmets and worth throughout the $1870 \mathrm{~s}$.

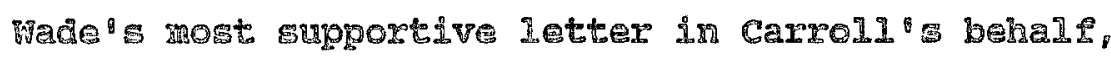
however, was not published until 1881, three years after his death. In that Letter, dated April 4,1876 , Wade claimed credit for convincing Iincoln to use carrol1' plan in spite

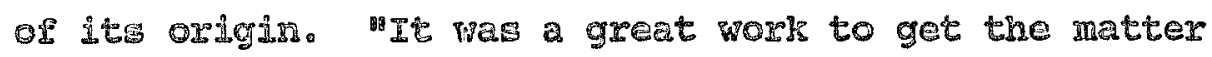
started: you have no laer of it. We almogt fonght for it." The need for "absolute serrecy" at the time had precuded. recogrition of Carroln then, but 4 in ever there was a righreous Glein on eath, you have ore." ${ }^{38}$ 
At first glance, Wade's letters might seem to remove all doubt regarding the legitimacy of carroll's claim. As the chairmar of the committee on the conduct of the war, Wade's approval of her claim would be powerful support. But there is no evidence that the comittee over discussed the movement up the Tennewse River. Momt of their published hearings conceming the Western Theatre duxing the time Gaxrol set her dain (the winter of 1861-1862) dealt with

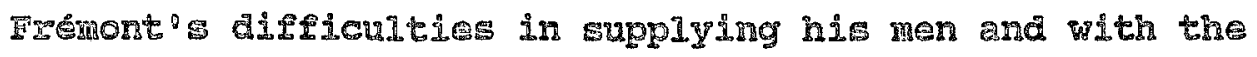
confusion in command at the Battle of Fort Donelson. ${ }^{39}$ No evidence exists to suggest that wade and his condite ever dealt whth the strategy of the Tennessed campaign. Horeover, carolire wade, the senator"s wite, was on slose torms with Carroll. It was through caroline that Anne CarroI corresgonded with Benjamin Wade. Conidering her penchant ror bypassing middiemen, it would hardy seem Iikely she would use intermediry to aproakn Fade on such a vital ratter as establishing her alain. It would seer Iogical, therefor, to assume thet wade had at first simply written a rice letter of thanks to a loyal aitiren who had told his wife and him what she deserped oredit for. And, as the yeas went by, carroll no coubt convinced the aging Senator she deserved more thar thanks for hex work. Wade,

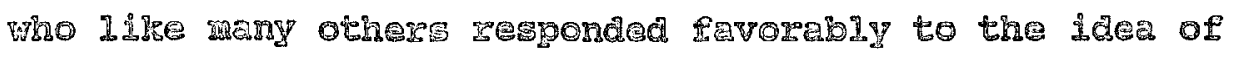
Carroll as a sezolme, Bav in ner alaim a chance to thans all

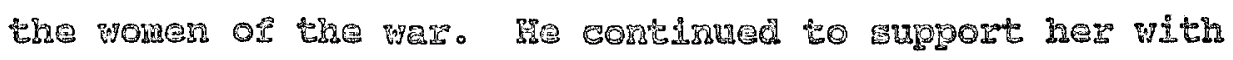


letters of increasing fulsomeness. But the strongest letter, that of 1876, that clajmed he had fought for her plan was almost certainly a forgery. However, Wade's endorsement of her claim in 1869 had clearly, for Anne Carrol1, provided enough evidence to bring her claim to the public forum and pursue it through congress. 40

She began slowly enough, couching her petition for payment with feminine delicacy and in the mildest of tems, and reassuring Republicans such as Robert $G$. Schenck that "in pressing my claim . . I cannot by any possibility detract from our brave and heroic commanders.... "4l As her petition failed to attract notice, she determined to strengthen it with rore favorable testimonies. She wrote to John Tuaber, former Assistant Secretary of War and still associated with Thomas Scott, to see if scott, who was out of town, would support her claim. He was sure the colonel would, Tuels: wrote, and would give nim the papers when her geturned. As for himself, while he was "much obliged for Yous offer of a R. Road charter in Fexas (where Lemal Evang was Chief Justice of the state' suprene conpt and where scott was roping to develop the pexs and Pacific Railroad, it did not suit him, "at this time, to avail of It. ${ }^{80} 2$

suge exongh, when scott returned, he wrote a letter

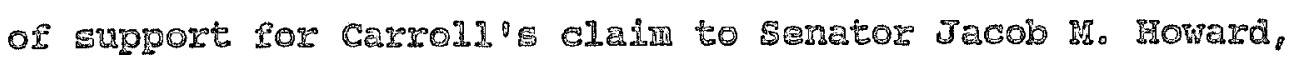
Chairman or the committee on Military Affalm. ${ }^{43}$ But shree 
scott's letter referred only to Carroll's pamphlets, which scott thought "were valuable at that time and served a good purpose," Howard apparently questioned Carroll as to why scott had not mentioned her military strategy. Scott had told her she "had better not," Carroll explained, "because military men vere very tenagious \& jealous." ${ }^{44}$ f few days later, scott wrote a second letter of support, this time, and for the first time, incluaing a specific mention of Carro11's Tennessee Plan, "which plan I submitted to the Secretary of War, and its general ideas were adopted." "Through the adoption of this plan the country had been saved milions, scote wrote, "ond that.. entitled her to the rrind consideration of congress. 145

with additional groof of her service provided by Scott along with the mpport of Ben Wade, carroll thought victory was at hand. "I have wonderful friends, she wrote her Eather from whington in January 1871. "MII my 1abours nere brought me friends." The comitte or military fifairs reported 1avoraby on her claim and recommended she be paid LOr her "righ!y merltorsous services."

mare the matter rested. Read, passed to a secord reading and printed, the bill never moved out of congres: 87 marytand serator ceorge Vickers thought it might be due to Carrol I o anti-Regubljean sentiments. Perhaps if she "had pressed it in 2865 \& 1866 before the Loyalty of some had cooled, he wrote, her "prosgects for 
success would have been greater. "48 Carroll blamed inaction on the bill on senator Henry wilson for failing to "take care of" her in the senate, and on Chairman Howara himself, who had "proved a traitor \& would have done me injustice. . You have no icea how false he played."49 Defeated but momentarily. Carroll worked to gather more letters of support and to increase her visibility as Claimant. She made friends with Samel Iunt, secretary to Henry wilson, the new chairman of the committee on Military Affairs, and did all whe could to curry Hunt's conficence. As an ingider, Hut suggested she nse publicity to help her claim and obtaln as many supportive letters as she could. ${ }^{50}$ Carro11 wrote to Hillard Fillmore, who rememberea thedg meeting in November 1861 on her way back from Tennessee, but conld remember nome of the specifics of the convergation. Besides, he wrote, he was gure that with the Savorable repor: by Howard she would prevail in Congress

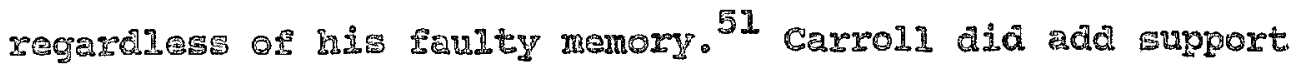
to ner dalm in the form of letters geceived in the 1860 w mhich had complimented her or her pamphlets and justified their price rrom such men as :dward Bates, Fdwara Everet, Reverdy Johnson, and Horace BInney. She Included as woll a statement on the value of the Turresse strategy from chief

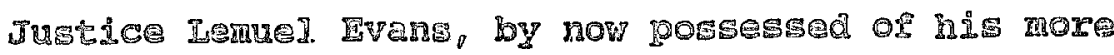
impressive titer. 52

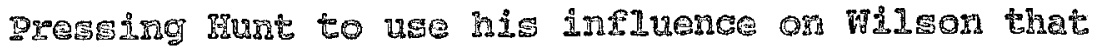


winter, however, Carroll confronted two immovable individuals. Hunt was not willing to jeopardize his future. He had to be cautious, he later wrote carroll, and not appear to be her advocate or his usefulness woulo diminish. wilson would not place the bild on the calendar and would not discuss ift with Hunt at all. Eparanty ne wanted more proof. 53

Hilson received addittonal proof of a sort in the form of a pamphlet published to support carroll's claim. Although issued anorymously, the arthor was Lemuel. Evans. 54 Hiss Carroll, he wrote, "had the genius to grasp the situation and perceive that the fald of Richmond could not destroy the rebellion, and the Mississipoi river could not be opened on irs waters: that the Goverment must seize 2 stretegic position within the cotton states, and 21 a fatad blow could be inflicted, it mut Call there." To Carroll, alone, "therefore, must be given the credit of having olved the problen the military destruction of the - Southerr Contederay. 0055

In kis pampingt, pulolished in the winter of 1871-1872, Evans added an additional lauxel to carrol1's wreath by including a letter which she was said to have written regarding Viclsbourg llater dated in testimony as having been writter in octolsw 1862 ) pointing out that

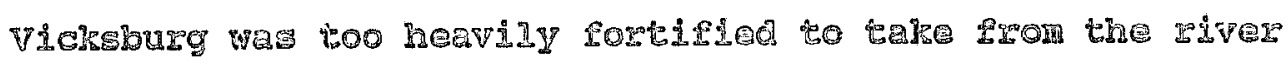
phich the federd? had discovered as carly ac the previons 


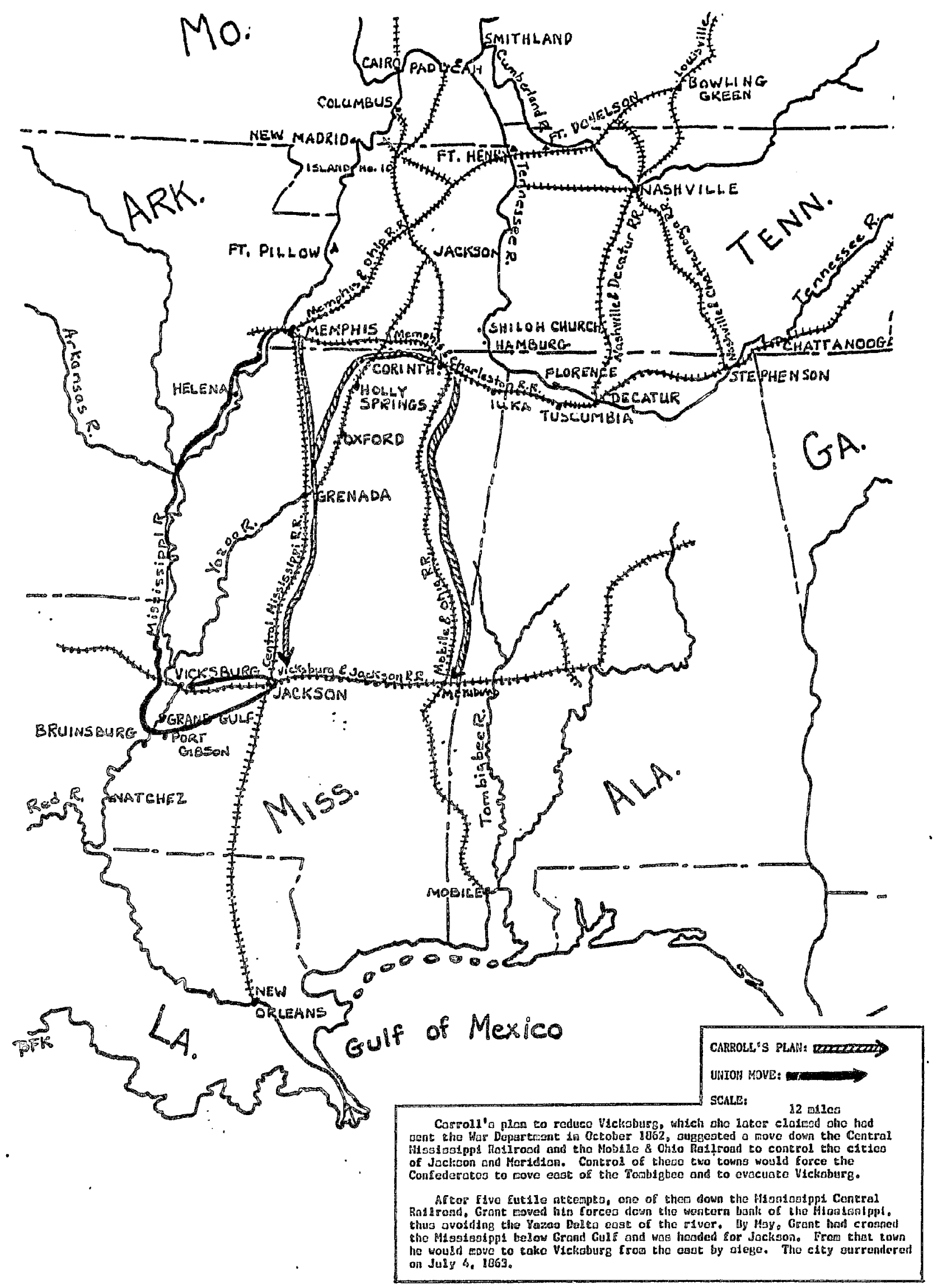


spring when Admiral David G. Farragut had failed to take the town) and recommended that the town be taken by a land route. 56 In her letter, almost certainly a post facto creation since no evidence exists of its fortuitous receipt by anyone connected with the Vicksburg Campaign, Carroll argued for a trip down the pississippi Central Railroad from Memphis to capture Jadrson, Mississippi, and cut off Vichsburg from the east as the most "'econonical" plan. 57 Grant had in fact made such a nove, but was driven back irs December 1862.

Saving the government money had become part of Carrol's claim to fame in this pamphlet. After all, she had saved the government "three thousand millions" of dollars, Ivans estimated, by her work in the war. Surely congress would not begrudge her what he suggested she ask for: "the pay of a Hajor Gene'1 from Hovemier 30 or

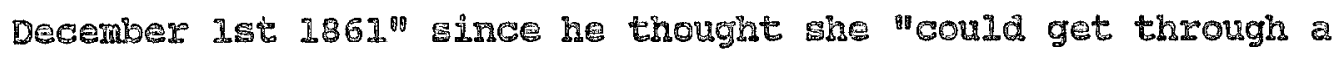
1arge Swr in this form that might be more appeading than a mpecipic doldar amonne would be. 58

funt agreed with Evang' İde. He Later wrote Carroll that se thought her method of asking for money was "rather pretty and practial" and no doubt befitting her womanly nature. Her claim, he thought, was more valuable because she was a "woman" and thus a syabl of al the women or the wer. 59 It was beconing painfully apparant to Garroll, however, that her continued push for recognition 
and payment of her clain was meeting with considerable disapproval, particularly among her female acquaintances. She dismissed it, however, reasoning that "women . . are as a class jealous \& envious of their sex. None are allowed to come around me, except that Miss Munroe who is a great bore I have no doubt would at heart rejoice, if she could have seen me defeated." 60

By May 1872, Carrol1 was convinced once again that she was winning the battle. "My enemies have fought me desperately to defeat me or rather my claim," she wrote her father. "We fought them and contested every inch on the Battie field and the Iord being my Helper in His own good time has given me great extraordinary victory!" But Carroll spolse too soon. The bl11 for her rellef was read and refered to the committee on Miltary Afairs, where it died. "you can't trust a professional politician, carroll told her gister. But she had hope nonetheless. "It is wonderful with what strength \& energy our Father in Heaven exdows us in such peculiax trying times...$^{61}$

By Argust, carroll vas ready to do battle again. She went to New York city to work for the Republicans in the presidential dection, though she was less interested in getting Grant electeo" "so narrow and selftsh his nature" than 1 working for Herry wiIson as his vicempresident, no doubt deciaing wilson's gratitude cor her support would help her cause in cngress. Whe vicempresident, "a respectable 
man," she wrote, "will carry the ticket."62 In November, anxious over a new round of hearings on her claim, she contacted Hunt, who remained with wilson after the election. She asked if he could "think of any one in this city who has more than ordinary influence with wilson? one whom I could approach by an offer of money $\$ 1$ successful. I would allow any per centage at all could I find the party of the right status.. ." With Grant returned to office, carroll trought, the Republicans "can surely now be magnainous - . In conceding my rights" since Grant, after al1, "has never claimed to have done the service to the countigy of planming the Tennessee Campaign. 63

Carroll flnaly appealed to wilson simself, telling him that "president crant as long ago as 67 , advised me to dain the service in history" and "Judge Wade says, that the President desires to see me rewarded and widl stand by me. Give justice now, she pleaded, for "if I am not successfuI non after aId, I mhall not live I fear ever to

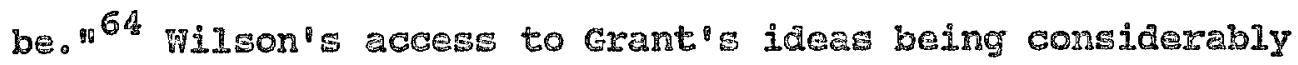
greater than carroll's, certainly had crant desired her to have been recognized, she would have been. But congress adjourned with no action taken on her claim.

Immedately after the new year, Carroll reached out sor public suport again with a new pamphlet which restated her CIaim and added the argument that, since historians conld not agree or whose daea the campaign was (they 
credited Halleck, Grant, Foote, Buell, Mcclellan and Frémont), it was clear that the idea "had no part in the plan of any of our generals and was at the tine Miss Carroll submitted her plan to the Department unknown to the Government. " 65 Ben Wade had written another letter of support for her, telling the committee that Iincoln had informed him "that the merit of this plan was due to Miss Carrol1." secretary stanton had agreed, and "fully recognized" (on his deathbed, according to Wade) "Miss Carroli's service to the Union in the organization of this campaign. "66

Throughout 1873, Carrol1 gatherea letters of support for ner next assault on congress. Cassius $\mathrm{M}$. clay, united States Minister to Russia in 1861, endorsed her claim, telling her he saw "no reason why officers and soldiers who fought in the field shovid be nore entitled to honor and emoluments, than the many cminient women, who showed great patriotism and rendered ssential aid. . . Vieles promised his vote the next time around, but advised her she should condense her claim to maje it easier reading for busy polltialans. 68 carroll, also wrote to civil war historians I. T. Headey and Dr.D. W. Draper, correcting their histories of the war. 69 Irmul Ivans supported her gtill in this new round, warning her to kep her clam above politede it whe could, "by extrene circumspection-memaining whol1y in the bagrground." Get the appopriation first: 
then she could "write or visit or mix in any movement . . . "70

In september, everything stopped for carroll as her beloved father fell ill. He died on october 3. Carroll was devastated. "I have lost the best Father, the most perfect of all the race, not in my judgment only, but in that of alI who had the fortune to know him."71 Her deep grief did not blind her to practicalities, however: shortly after her father's death she questioned his former lawyer in somerset county to see if the sale of her father's home back in the 1830s had been proper or not. If the estate was entailed, for Instance, she might be able th get it back for her brother Henry. No, wrote Isaac Jones, "I have never heard any question of the absolute title in the grantee of your Iather."72 All Carroll would inherit was her father's good name. Her unele comforted her: his brother might have had "the usual caxoll-1nimity of great lack of the faculty of making money," he wrote, but "he had all their nobility of character, kindness of heart and sympathy of nature, "loving "his family and children with almost feminine fonaness....

By 1874, Carroll was back at work. Hex publication of another pamphlet had attracted the notice of charles M. Scott, who defended himself as true athor of the Tennemsee Plan in a letter to the New York Daily mabune. ${ }^{74}$ Questioned once agein by the committee on war 
claims about her lack of contemporaneous proof regarding the official nature of her mission to Tennessee, Carroll had "omitted" any statement in her early claims, she replied, "that to render my services more effective" she had told colonel scott she would visit the west. While she had written to scote when she was there and at his official request, regarding "any thing that I might deem important to the cause," she stated, he had not written to her because he was afraid his letters would not arrive in time and because he lnew whe would be returning to washington soon. ${ }^{75}$ Another pamphlet cane out in Decenber 1874. In that one, Carroll at last responded to the resistance to her miljtary claims and made her literary services a "aistinct and separate claing" from the more controversial military service. 76

CharIes Scott's attack in the press had hed an

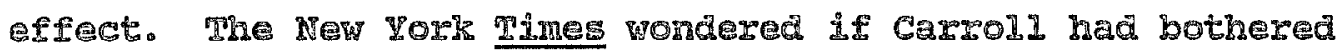
to press her claim while lalleak was still alive, since he wes the obvious author of the plan.77 carroll's defense of her claim and her assertion that she had started her petitions prior to his demise was not printed in the rimes, but she was given the chance to respond in public at Iast. ${ }^{78}$ on a pot JuIy day in 1876, the two clairants faced

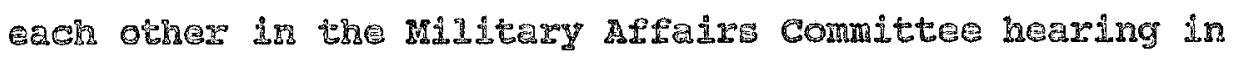
Washington, and carroli, with Evans by her gide, wore dom

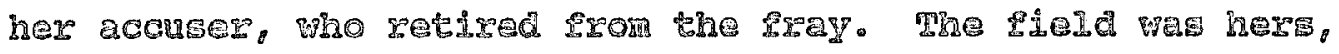


and with scott more or less consigned to the oblivion of the Midwest once again, she renewed her battle. 79 But the battle would soon be hers alone. Iemuel Evans died in Washington July 1, 1877. The Galveston Daily News took note of his passing, surprised that it seemed "to have been an event les: noted by the press of the State than would have been anticipated...." 80 carroll went on without her close frient. Another memorial was introduced in October, shortened to eleven pages and asking for compensation for her work "somewhat in proportion to its value to the country." ${ }^{81}$ In 1878 , a poetical version was filed in the 45th congress that confronted public reluctance to accept the validity of carroll's claim. This massive memoriel, wich reprinted all the petitions, documents, menorials, reports and pamphlets that had previously issued In the case, praised the inteligence and alscernment of the American public and asked congress to put the mater before them. "Iet the people grasp the merits of this case, and understand what results followed the adoption of this plan, by which the unity of the united states stands to-day, and we can trust them to... plate the reward... so as to comect it fairiy with the benefits the nation itself received." A2 Afer all, "1he transfer of the national

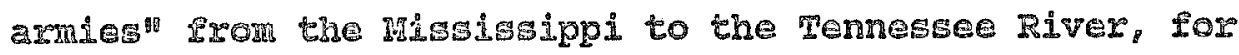
which Carroll was regponsible, "was the greatest military event in the interest of the sunan race known to moden 
ages. It was nothing less than the beginning of $a$ new and higher civilization . . . ${ }^{83}$ Perhaps, but the memorial was still referred to the House Committee on Military Affairs where it languished unto death. 84

At long 1ast, on February 18, 1879, came an answer to a congressional petition. The senate comittee on Miltary Affairs, in reply to Carroli's Memorial of 1877, issued its report. The comittee decided against carrol1. Every congress since the civil war, the committee argued, had had a chance to reward her and none had. "There must have been, "therefore, "some very grave and important reasons underlying the non-action of these congresses in these premises..." She had been paid $\$ 1,250$ by Thomas Scott and another $\$ 750$ by Assjstant Secretary Watson. Two thousand dollars for her pamphlets was plenty. Is for $\mathfrak{h} \in \mathrm{R}$ miltary strategy, all civiliged nation honored the names and deeds of momen Iilse Florence Nightingale and Clara Barton "because they are heroines who have rigked their lives in the cause of humanity" But if they, Iire carroll, applied for a monetary rewazd, why "it would destroy much of the poetry and grandeur of noble deeds" and smacls of

"hueisterism" and barter. carroll should be satisfied with the monies received and, should she want more, whe deficit should be suplied from the large gtore of gratitude which - . republics should bestow upon their c1t1로요. 85 
Carroll must have been crushed or, more likely, infuriated. Perhaps it was the condescending and patronizing tone of the committee that implied womanly deeds ought to be self-sacrificing enough to pay the printer that brought carro11': case to the interest of the woman's 5uffrage movement. Carrol had notified the suffragists Ierself in 2873 , when she sent copies of her early petitions and memorials to Matilda Joslyn Gage at the National voman's Suffrage Association's annuel convention in Washington. She thought, perhaps, it might interest Mrs, Gage, "inasmuch as it: may serve In some degree to furnish evidence in behalf of the cause you so ably represent. 186

Gage book up the cause, about which she published a pamphet with the combative title, "who planmed the Tennessee Canpadgr of 1362 ox Anne FIIa Carrol1

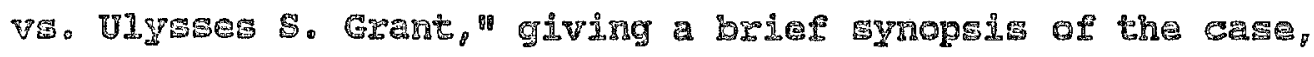
painting carrold"' clain in the dight of injustice of "man toward moman. Carroll, a "young girl of Haryland, full of a patriotic ppirit, "had developed a plan which had saved the union. Wowhere in the world had there ever existed "a person gossessed of the transcendant [Gic] military genius of Anna w11a Carro11." Yet Grant war fêted and honored and remelected, while carroll, the plas"s true athor, "in mrregarded solitude," sought from congress but a mimoIe

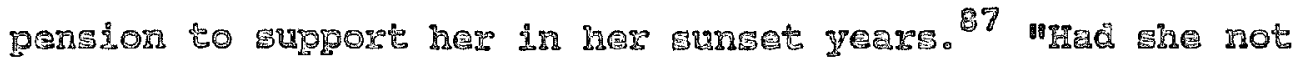

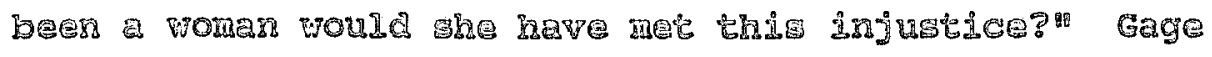


thundered rhetorically. ${ }^{88}$ Actually, if Charles scott's experience were taken into consideration, the answer might well have been yes. But no matter. Here was a cause worth fighting for.

Carrold's choice to seek support from the National woman Suffrage Association instead of the state-based and more conservative American Woman' Suffrage Association made sense considering their respective constituencies. Unfortunately for Carrol1, however, in 1873 the NWSA was stid suffering public censure for the radical free-love ideas publicized by WWsA member victoria Woodhull in 1873 and 1872. The outcry against woodhuII had cost the fourmyear old organization much of ite support and public approva1. It was not an effective organdzation to rnount such a campaign as carroll reguired, especially considering the controversial nature of Carro $11^{\circ} \mathrm{g}$ mintrary claim. ${ }^{89} \mathrm{By}$

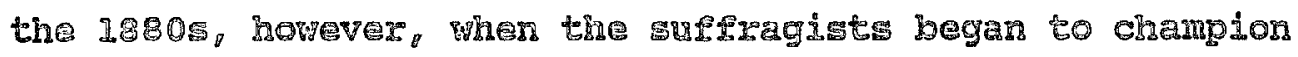
CarroI' ${ }^{\circ}$ cause, members from both the MHSA and the Ams would wite on carroli's behalf. Gage's article was printed first in the national Citigen, the NWSA' morthIy newspaper, and then brought out as a parphin. One nore petition by carzoll to congress sollowed. Carroll asted Thomas scott for help once again. but scott had wuffered a strole two years previously. and though his mind was Glear and he continued his presidency of the Pensylvanda Railroad, he was, hit amsistant rrote 
Carroll, "too broken down by overwork" to be of any help. Ben Wade, her other constant support, had died in 1878.90 Carroll was on her own this time. Called before the committee on Military Affairs in Jamuary, 1881, she was momentarily at a loss when she was asked to tall about her claim rather than read it. But she spolze for an hour and a half. ${ }^{91}$ As had been true throughout her 1jfe, her forceful personality and speech seemed to impress those whom she dealt with much more than did her weter work. on March $3_{6} 1881$, former Union general and Representative Edward s. Bragg, chaiman of the comitte, reported a bill for ser relief, finding that "the evidence - - completely estaolishes that Miss Anne Ella Carroll was the author" of the Pennessee Campaign Plan that gave "mastery of the conilict to the rational arms..." The "thangs of the nation" were due riss Carroll, and it was the recommendation of the committee that she be giver a pension "as a partial measure of recognition for her public service... .92 The pension, Carroll hoped, hould date from November 30,1861 , but whe would "take whatever I can get as thine is important .....93

Time was very important. In 1881, Anne carroll was 66 years old. Hex contemporaries who had supported her were dead and gone. she wes forced to zely on new sources for aupport and those took time to cultivate. She had contacted James Woram Gariela arter his Repubican presidential 
nomination in 1880, offering a manuscript on Maryland's colonial history for his perusal, warning him about an alliance between Democrats and the Pope, and asking for five hundred dollars or so to publish an anti-Catholic pamphlet; in short, repeating all the activities which thirty years previously had established her relationship with Millard Fillmore and the Know-Nothing Party. 94 she congratulated Garfield on his election, finding it ${ }^{\prime \prime g o}$ remarkable that I do not see how any true Christian can doubt that God rules and controls the governments of men." 95 when she came to Washington, she would call on him, she promised, but in the meantime, she enclosed the March 1881 report on hel claim, "sure it will be gratifying to you, that this measure of sนccesฐ has been attained ...." 96

But success was short-Iived. Carield, whose brief, polite answers to carroll'g letters no doubt encouraged her Into considering him a good fyidend and ardent supporter, was assasgirated in the summer of 1881. Carroll suffered a paralytic stroke in early september, and congress adjourned without passing the bill for her rel Ief.97

A voman suffering from injustice at the hands of the male-doninant national government provided the suffragists with a carse. The cause could be made ony more glorious by that woman' Exajty. ilness, and poverty. Matilda Gage

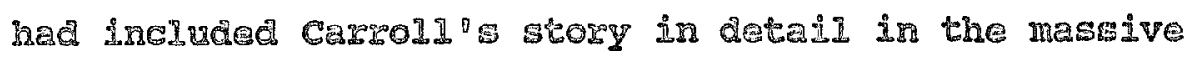

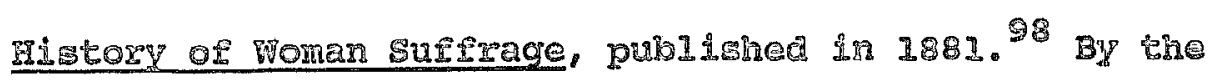


following year, Phoebe Couzins was able to portray a woman "unhonored, unsung and paralyzed," who lay dying "within the shadow of the capitol," where the Military Affairs Committee aid its work, awariing pensions to the far less deserving. The "gilence and selfishness of nen" were permitting Carroll'g great doeds to "pass into oblivion," wrote Couzins.99 xa truth, one man did ween to be all that stood between carroll and her pension, which, if the war Department refused to pay the b111 yor her pamphlets was the least she deserved. Former confederate Brigadier General, now Missouri Democratic senator Francis cockrel1"s "determined opposition" to Carroll"s clain rept the bill fron a final vote. ${ }^{100}$ Added to his opposition, wrote Denocratio Fepresentative Edward s. Bragg, was that of the Wrar Departmat as a whole. It stood firmly against the clain, considering it "aksurd . . that a woman" knowledge of copography and gtrategic lines led the advance of the

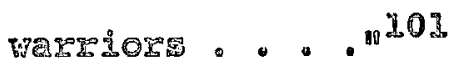

The support frow suffragiste was a double-edged sword. While carroli gained organized and wide-spread publicity, mmbexs of the comittee on Military Affairs manifested "very strong opposition to woran"s rights, suffrage, etc. which was made to prejuaice [the] claim, though having no alract connection with the case, of courge."102 But carroll ${ }^{\circ} \mathrm{g}$ invitation $\ln 1873$ to the suffragists to take us irer cause did fom a connection and. 
for better or worse, she was inextricably linked with the political movement for woman's suffrage. Republican Representative John D. White of Kentucky pointed out the connections in his speech on February 7, 1884, comparing Carroll's claim with that of Fitz John Porter. Undon Major General Porter had been cashiered from the army for disobeying an order in 1863 and had spent many of the ensuing years petitioming congress to clear his name. He had, according to White, suffered wrongs which congress hac taken weeks to consider. Carro11, on the obher hand, had suffered far greater wrongs, but, White argued, "because she is a woman and can not help herself, and because she has no political power to bear... for twenty years her claim has been dishonored." "Does any one doubt for one

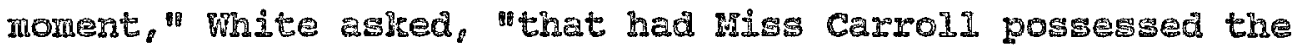
powerfut political influence of Fitz Jom Porter. . she long ago [would have] received every dollar" of her c1.21ำ 203

Mhat was the question asked agein and again by the surfragists. Where Congress had falled. perhaps public opinion could succeed in gaining carroll justice. while the suffragist. prepared the matter for the puble, Carroll morged rithin the sygten one more tine. On January 29, 1885, พ111ำ clain for Carroll in the United states court of clains. 104 Anna E1 La carroll v. The United Staces was decided 
by June 1, 1885. Time was of the essence, her attorney argued, for although carroll's health had improved, she was still ill and had no income save a pension from the "National Woman's Aid Association."105 carroll's sister Mary had placed her in a private boarding home in Baltimore, and expenses were High. ${ }^{106}$ Using his son clifford's position as editor of a newspaper to drum up support for Carroll and thoroughly embarassing her sister and the rest of nex family with the publicity, Warden succeeded in gairing a favorable decision, or so he claimed. "The court of Claim today decided the carroll case in your sister's Eavor, he wrote to Mary. "Receive my congratulations accoraingly. 10107

But carrol1 had not wor. The court decided that chere vas simply no legal evidence to support her claim of miditary arvices. "Intil that fact be shown for it is certainly susceptible of proofy" Justice I. Nott wrote, "no court worla be authorimed in deciding that the strategy was not original with the military authorities who apparently plamed that advarce, and who were morally and officially responsible for lis success."108 As for her claim for Itterary servides, whide the documents she used for proof might "moxelly watisfy the fudgment of the individua, " they were nop evidence "whIGh Gan be received or considered by a

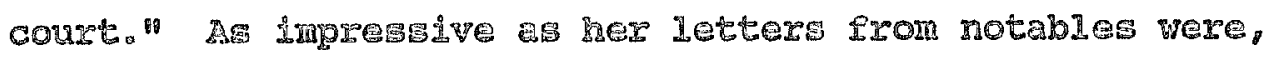
"as a cont we mist pronounce these certiricates as 
valueless as blank paper . . they establish no judicial fact." 109 There was no legal support for Carroll's claim. All the court could do was transmit its opinion as such to the House Committee. The only "victory" of which Warden wrote might be considered the Court's remark that congress Was not circumscribed by legal evidence to justiry its actions. It could, if it desired, base its reward to Carroll on the morality of the clalm. 110 It did not so degire. Another bill would be introduced in 1890 for $\$ 10,000$ for Carroll and once again would meet its fate in a referral to the comitte on Military Afrairs. ${ }^{111}$

As carroll went before the courts, the suffragists continued their literary campaign of support. carroll had recovered enough for a personal interview with journalist Mr. berpectacled, white-haired, short and stout but still animated, impressed shattrek. "Taking both my hands in hers, she held them tightly, while she looked into my eyes with an empression of such Ingenuous truth and honesty, that if I had ever any doubts or her wtory they could exist for me no longer." Untid she began to speak, though, one might suppose she was a "imple old lady" But relating her tale (which had grow grander as the years had passed), he wrote. " whe became the worderful woman to whom some day our country WIII do honor. "12

Carsol1 told her wtory of planning the campaign with 
appropriate gestures and "eyes as bright as stars." 113 She explained how she had talked to Grant after the war: "He was like a child," she said. 'He asked me all about it, and how I came to think of it: and until I described ny plan to him, and showed how success came from its consummation, I am convinced that he had no conception that it was this that brought us victory." Cargol1, wrote Shattuck, "Was cod" agent in the nation's day of peri1." And nov, "because anna Ella Carroll is a woman" she could get no recognition or reward, "arother instance of the ingratitude of repubias. "IId

Shattucle's article was followed a few monthis later by one written by suffregist Mrs. C. C. Hussey, and in 1886, Carrol1 hersele took pon in will-crippled hand to rewrite her story for the North American Review ${ }^{115}$ Mary IVermore included carrol1 ${ }^{\circ} \mathrm{s}$ story in her popular history. Hy story of the war 2 1889. Again, as did the other suffragists, she mphasiged that it was Carpol1's sex, "a fact for which she is not respons.ble ${ }_{\theta}$ " whlch had led men to Ignore her claim. 116 In 1821, the first volume of a short biography appeared, written by suffragist sarah Fllar Blaclurel and titied Ifre of a Military Gengus. 117

Blaclewe1 I had been corresponding with the carrolls

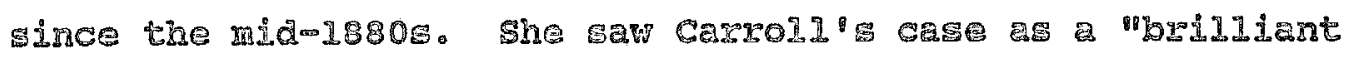
aremplyfication of the treatment of momen all the world

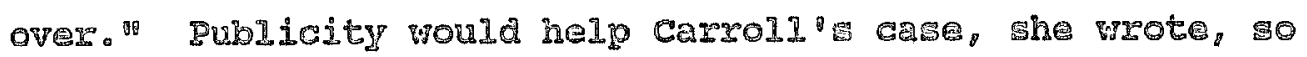


Blackwell placed letters that asked for a subscription drive for Carroll's benefit in the pages of the Woman's Journal, Woman's column, Century Magazine, and other periodicals. She was joined in her letters on behalf of the "Carroll Funä" by Mrs. Kussey, Abble M. Gannett, and Lucy Stone. 118 Susan B. Arthony wrote a rote to Mary Carroll, wrging her to trust the suffragints' support. "No man ever has-Or ever will put heart and soul \& brain into the worle of getting this justice done for Anna, whe told hex, adding, "only an earnest \& true woman can succeed. 1.19

The 1890 bill for $\$ 10,000$ failed beaten by senator cockred1 again. ${ }^{120}$ carroll, cared for in washington by her Youngest wister, rary, was at times nearly destitute, in splte of contributions from the suffragists. Mary had taken an appointment in the Treasury Department In 2836 thang to the interession of President cleveland's sister Rose and. possibly, her sister's letters to the President on her behal. ${ }^{12}$ She surered gey cut in 1888 and again in

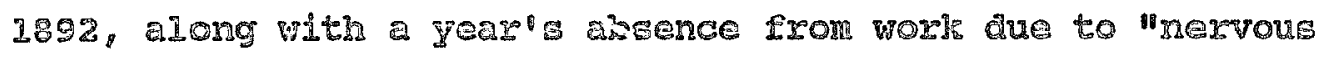
prostration, followed by a dismssal for absenteedsm. Her troubles promgted rrantic letter from Mary to the cleveland on behalf of her om paston and her sister" nesds. "groday I Rave not maxheting for tomorrow, "ine mpote, and, "I have no means even for required nedicine from

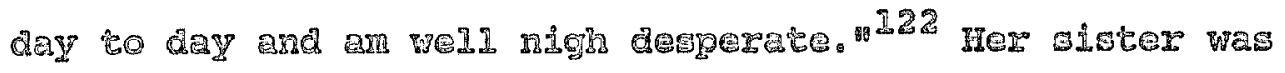
111, her own bealth was foiling, and her ramily was of no 
help. The Catholic Carrolls had long memories and did not forgive Anne for her early anti-Catholic writings; the secessionist Carrolls did not forgive her for her Unionism; the rest of the family were angry at having family matters continually put on publlc display and were too poor to help the sisters even if they had wanted to. ${ }^{123}$ The sisters clung to each other in their small Vashington some on 21 st Street, buoyed by visits from supporters, but financialy "1n great distress." 124

Rallying for a short while after a case of pneumonia and what was probably a second stroke in the sumer of 1893 , Anme Ella Caroll decined gradually in the fall and winter and sinally died on February 19, 1894. Partially paralyzed for thirten years, she had muccumber in the and to old agr and Bright' ${ }^{\circ}$ assease, a fadiure of the kidneys that was probably aue to circulatory problem comon in the chronia1y bedrialen. Har death certificate Iisted her

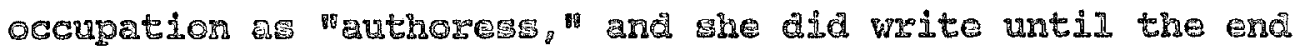
of her life, sGrathing out ouestions and answers when she could not speal, reading her visitor's answers and questons when she could not hear. ${ }^{125}$ fer body mas taren by her sidster to Dorchester County, MaryIand, where she was buried near her beloved father in the old Trinity church yard. Her Stone bear the true inscription, "M womas Raredy Giftedman Aole and Accomplished Writer" Bu below that ingmigtion,

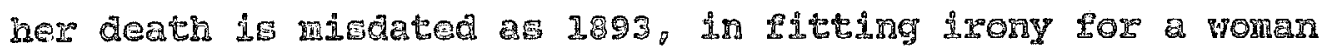


who spent much of her life trying to set her historical record straight. 


\section{Notes}

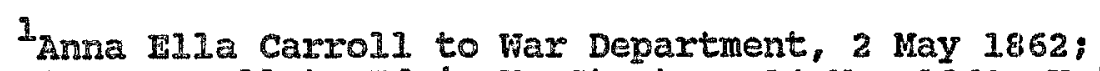
Anna FIla Carroll to Edwin $\mathrm{H}$. Stanton, 14 May 1862 , United states War Department, Record and Fension office, Carroll File, National Archives, Washington, DC.

${ }^{2}$ Anna EIla Carrol1 to Thurlow weed, 17 March 1861, Thur Ion weed Papers, Rus Rhees Iibrary, University of Rochester, Rochester, New York.

${ }^{3}$ Evans grew flustered when questioned about the trip in a congressional committee hearing on carroll's claim, first saying that he had net Carrol1 in St. Louis, then Washington, then Baltimore, eventually admitting that they had travelled to st. Louis together. U.S., Congress, House, Committee on Military Affairs, Petition of Anna Ella Carrold for Compensation for services Rendered to the War Department during the Iate par, 4 th Cong., Ist sess., 1876, H. Mis. DOC. No. 179, p. 15.

Anna Ella Carrol1 to Thonas Ining Carroll, 11 January 1869: Anna Ella Carroll to Mary Carro11, 30 January 1869. Anme Flla carroll Papers, Maryland Historical society, Baltimore, Maryland: Truman Smith to Lemuel D. Evans, 22 March 1874, Carrol1 Papars.

5. Iemul D. Evans to William F. Sewara, 3 March 1862,

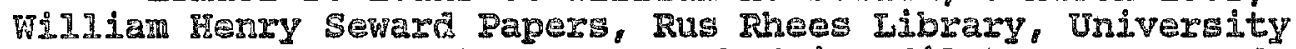
of Rochester, Rochester, New York (microfi.m. No records gurvive in the state Department or war Department that confirm this commission. General John C. Frémont's testimony before the committee on the conduct of the war indicated Evans was on his way to Texas by way of Tampico. Nexico, to flnd out if the Confederates were receiving

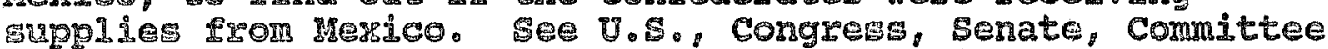
ors the Conduct of the War. Report of the Joint comittee on the conduct of tine war, $37 t$ cong." 3al sess., 1863, Rep. Com. No. 108, 4:120-121。

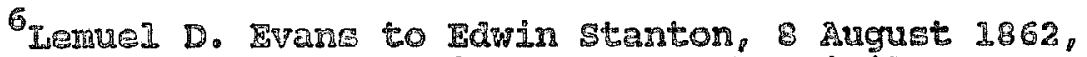
Carroll Papers: Samuel Richey Ramm, The civil War career or Thomas A. Scote (Phildelphia: University of Pennsylvania, 1940). PP. 130.133. 
7 Anna Ella Carroll to War Department, 25 August 1862; Anna Ella Carroll to Edwin Stanton, 9 September 1862, War Department, Carroll File; Anna Ella Carroll, Claim, 2 January 1863, MDHS 3650-183, Carroll Papers.

${ }^{8}$ P. H. Watson to Anna Ella Carroll, 14 September 1862, Carrol]. Papers. Receipt signed by Carroll is attached. The money for this payment, like the payment made by Thomas Scott, may have been personal. No record of any payment to carroll was found in the books of the war Department, the Provost Fund, the Secret Service Fund or by the Disbursing Clerk. See War Department, Carroll File.

Anna Ella Carroll to War Department, 7 October 1863 , War Department, Carroll File. No printed pamphlet appears to have survived, merely a notation on the file that it was received by the War Department. See also Anna rlla Carroll to Colonel Hardie, 7 october 1863 , Carroll Papers.

10 Anna Fila carroli to P. I. Watson, 8 January 1864, as noted os the war Department, Carroll file and guoted in Anna Ella Carroll to P.H. Watson, 11 January 1864, Carrol1 Papers: $P$.H. Watson to Anna Ella Carroll, 11 January 1864, War Department, Carroll File, notation only. The 8 Jamuary letter and the watson to Carrol1, 21 January, letters are summarized on the flle in the war Department but do not otherwise rurvive. Anna 필. Carrol1 to P.H. Watson 11 January 1864, Carrol1 Dapers.

$11_{p}$. Carroll Papers.

12 Anna Ella carroll to Brigadier Ceneral Mayer[?]. 9 November 1862, Carroll Papers.

13 Idward Bates to Anna IIIa Carrol1, 23 September 1863, Cargoll Pagers: Anna Flla Carroil, Essey on Military Govermment, mss draft, c. 1869?, MDHS 3652-425, Carroll Papers.

14 Anna FI12 Carrol] to [Sal1ie] Cradock, 12 May 1864. Carroll Papers: Anna Ella Carrol1. Recollections of Iincoln, undated nss, MDHS 3655-722, Carroll Papers.

15 Anne Fla Carroll to Salnon $P$. Chase, 8 December 1864, GaImon Portland Chase Papers, Iibrary of Congress, Washington, DC.

16 James M. MePherson, Orcieal By Fire: The Civil War and Reconstruction (Mew York: Alfred A. Knopf, 1982), PP. 
440-442; Allan Nevins, The war for the Union: The Organized War to Victory, 1864-1865 (New York: Charles Scribner's Sons, 1971), pp. 98-103, 105-108; T. Harry Williams, Iincoin and the Radicals (Madison, Wisconsin: University of Wisconsin Press, 1969), pp. 306-333.

17 Anna El Ia Carroll to Salmon P. Chase, 5 october 1863, Chase Papers. Carroll may have been referring to the despotism of military rule rather than the despotism of racial slavery. If she was raferring to the need for emencipation, it might have been solely for effect, since she was also attempting to pry funds loose from chase' Treasury Department for her pamphlets at the same time. 1854.

18 National Inteligencer, 18 October 1864, 8 Irovember

19 Anna Ella Carroll to Thurlow weed, 4 November I364, weed Rapers.

20 These is no mention of Cargoll or her offer in wead's biography or in is autobiography.

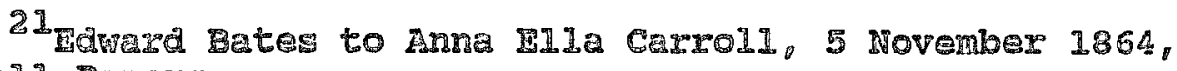
Carro 11 Papers.

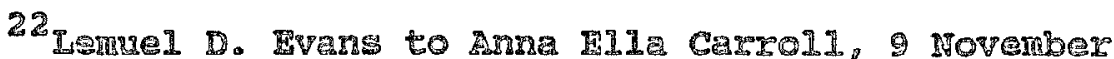
1864. Carroll Dapers. Carrol1 also wrote of Seaton's offer to her old friend and former minister, the IRev. Dr. Rolert Breckinridge, 29 Jovember 1864, Breckinzidge Famiy Raper, Isibrary of Congress, Washington, DC.

23 Josephine Seaton to Ama FII Carroll, I August 1866, and 27 January 2867 . Carroll Papers. Seaton finally wrote a short eulogistic biography of her father which was published anonymous Iy 18 1871. WIIIIan phinston Seaton of the Mational Intelligencer" Boston: James R. Osgood \& Co.0 1271).

24 Pational Intel1igencer, 31 December 1264, I January

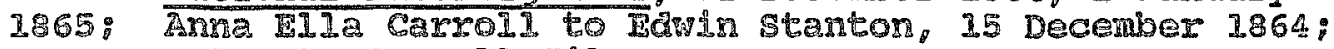
war Dapartment, Cargo1 IIII.

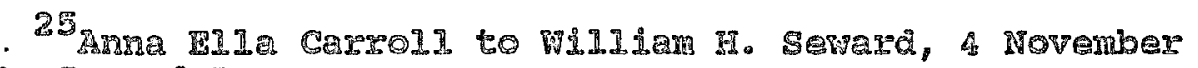
1865, Serazd Papers.

26 Ib Februay 1366, Gideor WeI1es Papers, Libraxy or Congress, Washington, DG. Carad 's history. AMnale of the Civil War was never sindshed probished, wince it was stored in a 
trunk of papers lost when Carroll became ill. Sarah Ellen Blackwell, A Military Genius: Life of Anna Ella Carroll of Maryland (washington: Judd \& Detweiler, 1891), pp. 251-152.

${ }^{27}$ George Gibson, Recorder, Board of Claims, War Department to Anna E1la Carroli, 14 July 1868, Carroll Papers: Anna Ella Carroll to Board of Claims, War Department, 22 July 1868 , Carro11 Papers: Thomas A. Scott to George Gibson, 27 November 1868, Carroll Papers.

28 Branta Mayer to Anna Ella Carrol1, 7 october 1867 , Carroll Papers.

29 Anna Ella carroll to Aaron Columbus Burro, 11 February 1869, Aaron Columbus Burr Papers, Yale University, New Haven, Connecticut. See also letters from Burr to secretary of State Familton Fish. U.S., state Department, "Ietters of Application and Recommendation Duting the Administration of J. S. Grant, 1869-1877," Record Group 59, National Archives, Washington, DC.

30 J. S. Serri11 to Jana Ela Carro11, 12 JuIy 1869, carroll papers, refers to anti-Johnson pamphiets but none has been found publishad under carrol1's name carrol1 was paid $\$ 40.00$ Lox an artlcle in Hanper's Magazine on Marylard hj.story apparentIy never printed. See k. M. Alden to S. E. Carrel1 [Gic], 9 December 1870, Carro11 Papers.

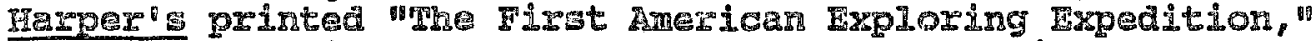
Fazper's Magazine 44 (Decenber 1871):60-64, which Carrol1 rewrote from her essay by the game neme in Ihe Star of the West. Barper' ${ }^{\prime}$ continued to misspell her name in ine table of contents as S. W. GaxrelI.

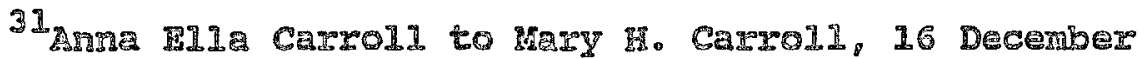
1868, Carroli Parers.

32 Anna IIIa Carroll to General Grant, 28 December 1868, Carrol1 Papers.

33 Anna FII Carroll to Mary H. Carroll. 30 January 1869: Anne WIIa Carroll to brother, 8 December 1868, Carsold Papers.

34.5. Congress, Senate, comattee on Military A3fairs, Pedition of Arna E11a Carroll, Praying compensation for Suggesting Certain Plans of operation for the Armies of the United States During the Late War 4 ist cong. 20 sess.,

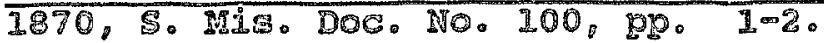


${ }^{35}$ Benjamin P. Thomas and Harold Hyman, Stanton: The Life and Times of Lincoln's Secretary of war (New York: Alfred A. Knopf, 1962, pp. 606-611, 637-638.

${ }^{36}$ Benjamin $F$. Wade to Anna Ella Carroll, 1 March 1869, Carroll papers. The original of this letter, in Wade's hand, survives. It was reprinted first in U.S., Congress, senate, Committee on Military Affairs, Memorial of Anne Ella Carroll Astring for compensation for service Rendered the United states in the war of the Rebelijon, 42 d

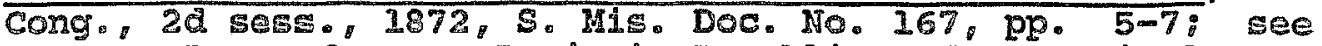
also $\mathrm{H}$. I. Trefousse, Berjamin Frankin Wade: Radical Repulsidcan from ohio (New York: Twayne Publications, 1963), p. 317.

$37 \mathrm{U}$. B. Senate, $42 \mathrm{a}$ Cong., $2 \mathrm{a}$ sess.

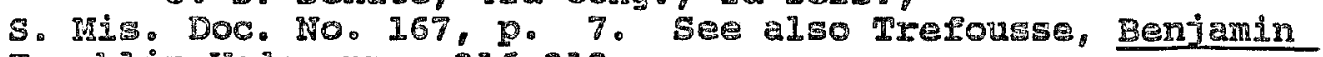
Franjiin wade, pp. 316-318.

${ }^{33}$ U.S., congress, House, comittee on Military Affairs, Anna ElIa Carrol1: Report to Accompany BiII II. .R. F2E5, 46th Cong., 3d sess. 1881, H. Rept. No. 386, pp. 1-3. Trefousse does not mention this letter.

39 Report of the Joint committee, $37 \mathrm{th}$ cong., $3 \mathrm{a}^{\text {, }}$ Rep. Como IYo. 108, VOI. 4.

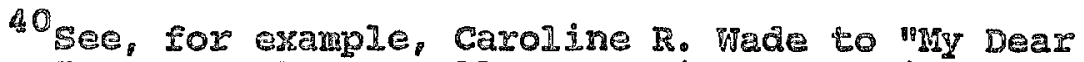
Friend, [Anna Ella Carroll], April, 30 April and 20 November 1869,1 Mazch 2870 Carrold Papers. Wade supported Foman"s suffrage. See Trefousse, Benjamin Franklin Wade, pp. $284-285$.

4I. S. Senate, 4Ist Cong. 2d sess. Mis. Doc. 100, pp. 1-2: Anna RIIa Carroll to Robert G. Schenci, 9 April 1870, Carrol1 Papers.

42 John pucker to Anna Ila carroll. 20 April 1870. Carroll Papers.

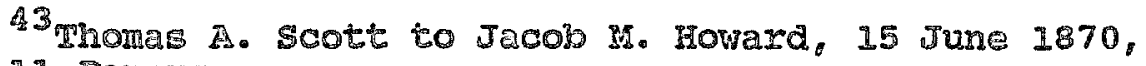
Carrol1 Bapers.

4 Amna FII carroll to senator [Howard?], 17 June 1870, Carrol1 Papers.

$45_{\text {Thomas }}$ A Scott to Jacob M. Howard, 24 Jume 1870 ,

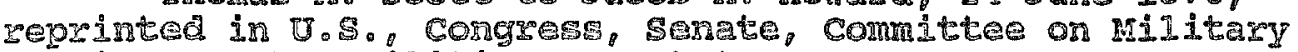
Affairs and the Millti, Report to Accompeny 5.1293 , 41 it

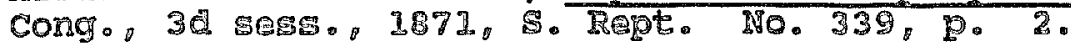


46 Anna Ella Carroll to Thomas King Carroll, 11 January 1871, Carroll Papers; U. S. Senate, 4lst Cong. 3d sess., s. Rept. No. 339, p. 4.

${ }^{47}$ U.S., Congress, Senate, Congressional Globe, 41 st cong., $3 d$ sess., 1871, p. 395 .

48 Ceorge Vickers to Anna Ella Carroll, 2 January 1871, 30 January 1871, Carrol1 Papers. Carroll fought against Republican party leader John Creswe1I in Maryland. See Jean Baker, The Politics of Continuity: Maryland Political Parties from 1858-1870 (Baltimore: Johns Hopking University Press, 1973), P. 187.

49 Anna Ella Carrol1 to [Samuel Funt]. 3 January 1871, Anne Ella Carxoll Papers, Carroll Craddock, Jensen collecition, Maryland Historicel Socjety, Baltinore, Maryland. Hereafter sted as cor collection. Anna Ella Carrol1 to sister, 2 March 1871, Carroll Papers.

50 Sarah Elien Blackwell, Iife and Writings of Anna Ella Carroll (Washingtor, DC: Juda \& Detweilex, 1895), P. 133: Samuel Hunt to Amne F11a Carrol1, 5 June 1871, CCJ Collection.

53 AnMa Fla Caroll to Millara Fillmore, 7 November 18\%1, Mi11ard Fi1Imore to Ama Ella Carroll, 10 November 1871, Mi1laza Fi11mole Papers, Buffalo \& Erie County Historieal society and state university college at oswego, Oswego, Rew IOR?.

52 U.S. Senate. $42 d$ cong. 20 sess., 5. Mis. DOO. Mo. 167, PP. B $-9,4$.

53 Samuel hunt to Anna El12 Carroll, 31 May 1872, 22 December 1871, Carroll Papers, CGI Collection.

$54_{\text {gvans }}$ acmitted authorship of the pamphret in $\mathrm{U} .5$.

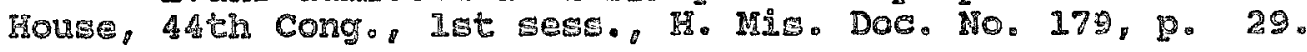

55 [Lemue] D. Evans]. The Materoia] Bearing of the Tennessee Campaign in 1862 upon the Destinies of our Civil War (Waskington, DC: W. Ho Moore, [1871 or 1872]), ?. 10.

56 Farragut had success in June of 2862 to join the Union river flest coming down From Iewphis to attack ViaksBurg. but 200-foot blufis on the river side and swamps north and south of the Gity weant only an eastern assault would EuGGerd. MePherson, ordeal by Fire, pp. 233-23A, 308-309, 312-312。 
57 [Evans], Material Bearing, p. 15. Carroll's suggestion (if in fact she made it, since the war Department file does not list recelpt of the october 1862 letter on its Carrol1 File) neglected to take into account the vulnerabiliti of Grant's supply lines that deep in enemy territory, or the fact that to move back to Memphis would be perceived by the publi.c as a retreat, no matter how strategically sound. She also did not consider the near-impassable swamps of the Yazoo Delta east of the Mississippi as a potential problein in moving ground troops. See rephergon, Graeal By Fire, pp. 311-312: Bruce catton, Never Call Retreat (New York: Doubleday \& Co., 1965), pp. $79-82$

58 [Evans], Materdal Bearang, $\rho_{n}$ 15; Lemuel D. Evans to Anna Ella Carrol1. 5 May 1872, Carroll Papers.

59 Samule1 Hunt to Anna Ella Carrol1, 13 January $18 \% 4$, carroll Papers, CGJ Collection.

${ }^{60}$ Anna EIIa carroll to sister, 22 May 1872, carroll Papers.

6IAna FII Carroli to Thomas King Carroll. $27 \mathrm{May}$ 1872, Carroli Papers: U. S. Serate, $42 \mathrm{~d}$ Cong., $2 \mathrm{~d}$ sess.,

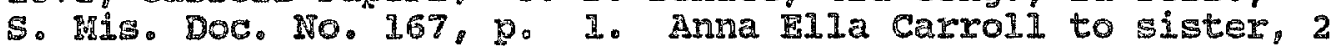
June 1872, Caxroll Fapers.

62 Anna EIIa Carroll, crant's Renomination, mss draft, c. 1872, MDHS 3653-508, Carrol1 Dapers.

$63_{\text {Anna }}$ EIL Carroll to Samel Hunt, 4 Hovember 1872. 6 Noveriber 1872 , Carroll Papers, CCJ Collection.

64 Anma FIla Carroll to senator wilson, 21 Hovember 1872, Carroll Bapers

65 [Anna E11a Carro11]. Miss Carrol1's Clajm Before Congress in connection with the Tennessee

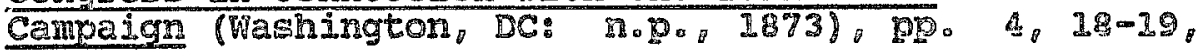
$22-23,36-37$.

$$
\begin{aligned}
& 66 \text { ISIs. P. \&2. }
\end{aligned}
$$

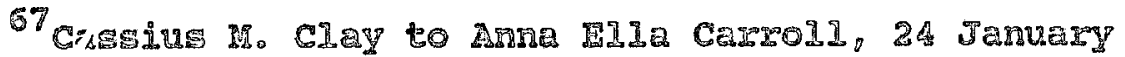
1873, Carold Eapers.

6E George Vicgers to Ama Ella Carroll. 31 January 1873, and 26 August 1873 , Carroll Papers. Cargoll's firet claln was two page: her 2871 memorial was nine: ber 1873 
publication ran to fifty-five pages.

69Anna Ella Carroll to Dr. Draper, 8 March 1873; J. T. Headley to [Anna Ella Carroll], 14 April 1873, Carroll Papers.

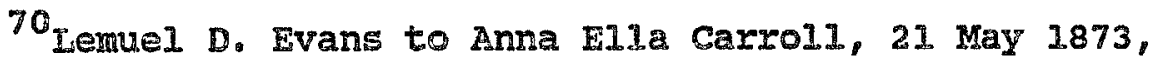
Carro11 Papers.

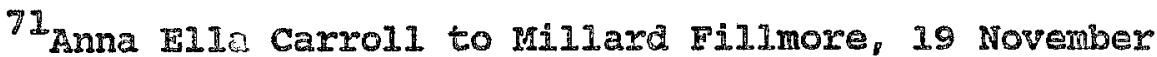
1873 , Fillnore Fapers.

$72_{\text {Isace }}$ D. Jones to Anna Ella Carrol1, 15 November 1873, Carroll Papers. Kingston Hall, purchased in 1837 by Johr Jpsher Dennis at the sherrif's sale of the property for Thomas King Carrol1's debts, still survives. I two-story brick house and litohen comected by a brick colonnade is currentiy being restored.

73 c[harles] C. Carroll to Anna Ella Carroll, 12 December 1873, Carroll Papers.

74 [Anna Ella Carrol1], Miss Carroll's Claim Before Congress Asking compensation for Military and other Services In Connection with the Civil war (n.P.: n.p., 1874). This one vas seventy pages long. A Clipoing of the Daily Tribune letter by Scott ated 24 April 1874 was preserved in a letter, Charles H. Scott to Anna Plla Carroll, 20 March 1865, Carroll Papers, CCT Collection.

75 Anna FIIa Carroll to committe on war Claims, 6 Jurse 1874, CCI Collection.

76 [Amma FIIa Camzol1], Miss Carro11's Iiterary Services to the country During the Civil war stated (n.p.: (1.P., 1874): P. I.

$77_{\text {Hew Yors }}$ Times, 14 Apri1 1874 .

78 pma Fila Carroll to Editor, New York Times, 4 May 157. ghis wes a rough draft of her reply which, if sent, was apparently never published in the paper.

790. S. House, 44th cong., Ist sess. H. Mis. DOG. NO. 279. For the full account of this confrortation see Chapter 5 above.

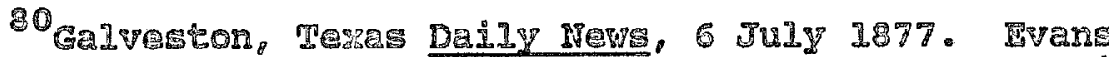
had riser to chlef Jnstice of the Peras supreme court in 1870, and was 1ts pres1atng juage until septombers 1273 . He 
was United States Marshal for the Eastern District of Texas at the time of his death, but died in washington, not Texas. Mentions of Evans in state and legal histories of the period are very brief. For a man whom John $C$. Fremont thought "so well known that it would scarcely be possible for him to reach Texas through Missouri country" because of his Unjonist stance, Evans is surprisingly invisible in the history of the period. Report of the Joint Committee, 37 th Cong. $3 \mathrm{~d}$ sess., Rep. Com. No. 108, 4:120-121. For information on Evans, see J. H. Davenport, The History of the Supreme court of the state of Texas fustin, Texas: Southerr Iaw Boof Publishers, 1917), DP. 95-96; The Handibook of resas, ed. VaIter Prescott Webi, 2 Vols. laustin, Texas: Texas state Historical Association. 1952. 1:576: James D. Iynch, The Bench and Bar of

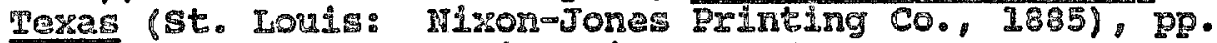
110-113: Comprenensive History of Tezas, 1685-1897, 2 vols., a. Dudiey G. wooten (Dallas: William G. Scafs.

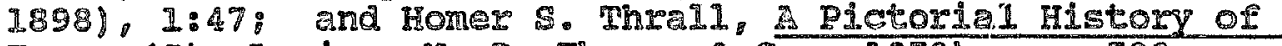
Texas (St. Louis: 3. D. Thomas \& Co., 1879), g. 532.

81. $1_{\text {U. }}$, Congress, Senate, committee on Military Affairs, Memorial of Anne FI1a Carroll of Maryland, Pray Ing Eor compensation for sexviced Rendered to the United States Durging tre Irate Civil War, 5 tin Cong., Ist sess., $187 \%$. S. Mis. DOC. NO. 5 , p. 11.

82. 5. , Congress, House, Commite on Military Affairs, Memorial of Anma Flla Carroli, of Maryland, Prayino Lor Compensation for services Rendered to the united states During the Iate CIVII War 55 th Cong. 28 sess., 1878, H. MIE. DOC. NO. 58, D. 2.

$$
\begin{aligned}
& 83 \text { Ibia. p. } 8 . \\
& \text { 84 Ibid. P. I. }
\end{aligned}
$$

85. S. Congress, Senate, Committer or MIItary Affairs, Report, 45 th Cong., 34 sess., 1879,

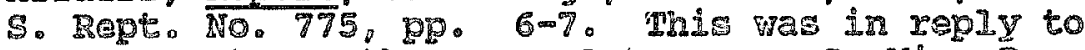
J. S. Senate, 45 th Cong. Ist sess.. S. Mi. Doc. No. 5.

86. Anra TIIa Camroll to Ratida Jos.lyn Gage, I7 January 1873. seprinted in Mt1da JosIyn Gage. Mho Planned the Femressee campaian of 1862 ? or Anna ELIa Carroll

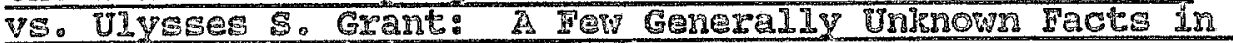
Regard to our cjvil War, National citizen Tract

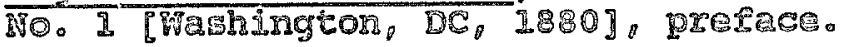

$$
\text { I7) Idog. 2-3. }
$$


${ }^{88}$ Ibid., p. 16.

${ }^{89}$ Nancy Woloch, Women and the American

Experience (New York: Alfred A. Knopf, 1984), pp. 309-324.

90 E. A. Rollins to Anna Ella Carroll, 5 January 1881, Camoll Papers. Phoebe Couzins (see n. 99 below) had interviewed Scott in 1380 at carroll ${ }^{\circ} \mathrm{s}$ request and found $\mathrm{him}$ in feeble enough health to fear he "might die at any roment." Phoebe Couzins, the Military Genius of the War, Ama 괴리 Carroll, author of the Tennessee Campaign (St. Louis: R.p., 1882), p. 4.

9I Ama Plla Carroll to Mary F. Carroll, 30 January 1881, Carrol1 Papers.

${ }^{92}$ U.S., Congress, House, Committee on Military Affairs, Anna Ella Carro11: Report to Accompany Bỉl H.R. 7256,46 th Cong., 3d sess, 1881, F. Rept. Mo. 386, pp. $1-3$.

93 Anna Ella Carroll to Judge [Jeremiah S.] Black, 1 ] February 18a1, Frederick Dreer Collection, The ristorical Society of Pennsylvania, Philadelphia, Pennsylvania.

9:Anna Ella carroll. to James A. Garfield, 15 JuIy 1830, 11 September 1880, 6 August 1880, James Abram Garifield Papers, Isbrary or Congress, Washington, DC.

95 Anne Fla carroll to James A. Garfeld, 3 Novenber 1880, Geifield Papers.

96 Mna rlla Carroll to James A. Garfield, 16 March 1881, Garfiela Papers.

97 Janes A. Garfield to Anna B11a Carrol1, 20 August 1880, Garfield Papers: New Yori Times, 15 September 1881. The story wes, Iiterally, front page news, presumably because of Carrol.' apring victory in the Congressional comittee. The pension was apparently set at fifty dollars a month, but never passed. See courins, The Military Genius, P. 5.

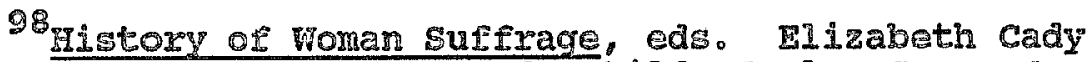
Stanton, Susan B. Anthony and Matilda Joslyn Gage, 6 vols. (Rochester, New york: Susan B. Antrony, Charles Man, $1381-1922), 2(1881): 1-2$.

$$
99 \text { Couzing, The MIItary Genius, 15. 5, } 8 .
$$


${ }^{100}$ Biographical Directory of the American Congress 1774-1971 (Washington, DC: Government Printing Office, 1971), p. 760; William Warden to Mary H. Carroll, 23 February 1884, carroll Papers.

101 Edward S. Bragg to Anna Eila Carro11, 26 April 1881, reprinted in Blackwe11, Life and Writings, pp. $133-134$.

202 William Warden to Mary H. Carroll, 23 February 1884, Carrol1 Bapers.

103 Hon. John D. White, Speech in the House of Representatives, Feloruary 7 , 1884 fiashington, DC: n.p., 18848, pp. 6,10 .

104 Wi111an W. Warden to Hiss Carro11, 29 January 1885, carroli Papers. It is unelear whether carroli, who was recovering from her stroke by 1835 , instigated the lamsuit or if her sister Mary dia. AlI of warden's letters but this one are to Maxy who, idving in Washington, may have simply jeen acting as her sister's agent. Arne did not join Mary in Washington until after Mary had a job. See n. I2I below.

${ }^{105}$ WIDIan W. Warden to Chief Justice Richardson, I3 February 1885, Carroll Papers. Aid in the lorm of subscriptions came from pleas in the press. See no 118 below.

106 william W. Warden to Mary H. Carro11, 27 October 1884, Carrol1 Papers.

107 wiliam 1885, 26 Apri1 1885, 1 June 1885, Carro11 Papers.

${ }^{108}$ Carroll $\%_{0}$ U.S. 20 Court of claims 426 (Court of Gaำ 2835), 429 .

109 IbId。, 430 .

110 IbId., 931 .

111 H. R. BIII 4835, 515s Cong. 2st sess., 13 January 1890, copy of printed bi11 preserved in carrol1 papers.

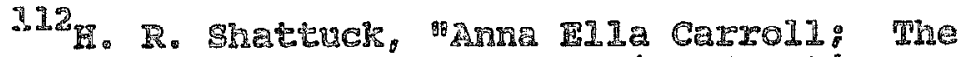
originator of the Trnsessee campaign," outing 6 fJuly 18858: $405-406$. 


\section{Ibid., p. 407. \\ ${ }^{114}$ Ibid., pp. 408-409.}

${ }^{115} \mathrm{c}$. C. Hussey, Miss Anna Ella Carroll, as Author of the Tennessee Campaign, in the Late Civil war (East Orange, New Jersey: Gazette Stean Book Job Brint Co.. 1885): Anna Ella Carroll, "plan of the Tennessee Campaign," North American Review 42 (April 1886):342-347.

116 Mary A. INivermore, Ny Story of the War: A Woman's Naysative of Four Years Personal Experience As Nurse in the Unior Army, and in Relief work at Home, in Hospitals, Camps, and at the Froste, During the War of the Rebellion (Hartford, Consectcut: A. Do Worthington \& Co., 1889), po 175. Iivermore's book sold 60,000 copies. "Mary A. Iivermore," Notable American Women, ed. Edward T. James, 3 voIs. (Cambridge, Massachusetts: Farvard University Press, 1971), 2:410-613.

${ }^{117}$ Blackwe11, Iife of a Military Genius. This volume was available at the offices of the Woman's Suffrage Society in Washington, and at the offices of the Woman's Journal in Boston, a sufîragist magazlne edited by Blaclkwell's mister-in-law, Iucy Stone.

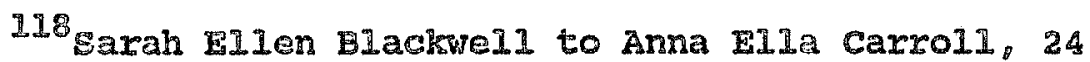
IuIY 1885, Carroll Papers; Sarah Fllen Blackuel1 to Alice stone Blackwe11, 3 January 1891, Blackwell Family Papexs, IDbrary of Congress, Washington, DC. The Woman's Journal has monthIy reports throughout 1885 on carroll and the Carrold Fund: see also Sarah Ellen Blackwe11, "The Anna EIIa Carrol1 Fund," Women's Column 6 (18 January 1888): alipping preserved in Anna Fila Carroll Filo National American Woman suffrage Association Papers, Iibrary of Congress, Washington, DC; Sarah EIIen Blackwell, "The Case of Miss Carro11," Century Magazine 40 (August 1890):638-639; c. C. Hussey to Editor Wonan's Journal 16 (7 Novwbex 1885):356; Abbie M. Gannett to [Mary H. Carro 11. 30 November 1885, Carrol1 Papers, CCJ Collection: Lucy stone, Editor, Woman's Journal 16 (19 December 2885/:404.

119 Susan B. Anthony to hary H. Carroll, 19 December 3889. Carroll Bapers.

120 Representative Gharjes 1 . Menderson to Anna Ela Cerzol1, 9 July 2890, Carroll Papers.

121 Mary H. CaralI to Grover Cleveland, 26 JuIy 185, 
Grover Cleveland Papers, Library of Congress, Washington, DC (microfilm); Mary H. Carroll to Rose Cleveland, 18 November 1885; Appointment given. 15 June 1886, U. s. Department of the Treasury, Personnel Applications, National Archives, Washington, DC.

122 Mary H. Carroll to Grover Cleveland, 27 August 1888 , and 6 september 1893 , Cleveland Papers.

123 Sarah Ellen Blaekweld to Alice stone Blackwe11, 9 February 1891, Blackwell Papers.

124 Isabel Howland to Editor, Inter-ocean, 30 May 1891, reprinted in Blackwe11, tife and writings, pp. 136-139: Mary H. Carrol 1 to Mrs. Frances Cleveland, 1 December 1893, cleveland Papers. A note attached to this letter indicates that President cleveland interested himself enough in Mary's case to examine her record. Her pay was eventuily reinstated. See carroli File, Treasury

Department Personnel Applications.

125 Death Certificate, Vital Records Divisiun, Department of Humar Resources, District of Columbia: Dr. William J. Perry to author, 24 April 1936; Blackwell, Iife \& Writings, pp. 140-142: Arma Ella Carrol1, Gravestone, Old Trinity Churchyard, church Creek, Maryland. 


\section{Chapter 7}

\section{Carroll as cause}

Anna Flla Carroll's story did not and with her" death in Washington in 1894. The suffragists' campaign had portrayed carroll as a woman denled recognition because of her sex. Because of her paralysis and then her death, Carroll's campaign for recognition took on an added poignancy. Her story took on added details. over the next hundred years, the legend grew of the woman who had saved the union through her briliant military strategy. The shahy foundation upon which it rested collapsed only under the force of scholarly investigation of her claim.

In the begimning, it seemed as if the suffragists would win their cause. Carrol'' story did not die, a fact that was by itself remarkable. She was included in the National Cyclopedia of American Biography the year of her death and Itsted as a strategist. President Iincoln was guoted in the entry as supporting her claim, though no 
source for the quotation was given. ${ }^{1}$ a year later, in 1895, former Representative Albert Gallatin Riddle mentioned her case in his Recollections of War Times, again quoting Iincoln as her supporter. Riddle's portrayal of a "short, stout, midale-aged maiden lady, intently listening through an ear trumpet" to debates in congress, continued the suffragist drive to have carroli recognized in spite of her sex. Riddle had been informed of carroli's plight by suffragists, or the "strong-minded" as he jocularly referred to them, but he failad in his attempt to persuade congress to reward her. His interest seems to have been momentary and may have been purely political in spite of his inclusion of carroll's claim in his book; he too misdated her death aะ 1893.2

The "strongminded" continued to fight for carroll. Sarah EIIen Blackwell published her second volume on Carroll in 1895. The small book, which sold for one dollar, contained reprints of Carroll's pamphlets and a torehing rendition of her deathbed scene. Subscriptions to the volume were sold through advertisements in the Woman's Journa 2. The Septembex 1896 issue of Godey's Magazine put Carroll on the cover as "The Woman that saved the Union." Iucinda chandlex retold much of what was included in Blackwe11' blography, but included ant of skulduggery by those determined to block carrol1's claim by disclosing the alleged thet of cagrold' papers twice from the committee 
on Military Affairs." The current Congress, she suggested, could "redeem their sex" from the "amazing cowardice" of preceding Congresses by placing carroll's portrait and a placrue commemorating her deeds in the Capitol. since she was dead, there was little sense in pursuing a monetary reward, but Chandler proposed recognition at the very least. 5

A monetary reward was not considered impossible. though, at least not by those who survived carroll. Someone, most likely hary H. Carroll, persuaded Maryland Senator Arthur P. Gorman to introduce a measure for the relief of the "legal representatives of Miss Anna Ella carro11. deceased" In JuIy 1897. Even with the suffragists" support and the added pathos of her death in poverty, however, carroll's claim continued to be referred to comittees for proper burial. ${ }^{7}$

It was not untiI 1910 that a defense of congressional inaction was published. The suffragists had argued for years that carrold had not been fully recognized because she was a woman operating in the male sphere of politics and war. But Ida M. Tarbell saw the supporters of carrold and her claim as an example of the unreasonable demands of suffragists. In an article on how American women were changed by the civil war, Taxbell argued that carroll's work had been duly recognized by the $\$ 2,000$ payment she had received for her pamplets and by the notice congress had 
taken of her military claims. The failure to compensate Carroll for her role as strategist, a role which Tarbell accepted unquestioningly, was due to the plan having come from a civilian instead of a military person. carroll's sex had nothing to do with it. Her claim had never passed simply because those things happened, Tarbell stated. carroll was recognized "emphatically and generously" for her military labors: she was just never paid. 8

Tarbell sought to prove that the suffragists were incorrect in their basic assumption that carrol1's sex excluded her from proper recognition. Further, because surfragists demanded recognition for carroll rather than accepting the decision of Congress ar appropriate, they were treading where they dia not belong. Tarbeli then extended that reasoning to argue that because the suffragists denanded voting rights, rather than accepting the decision of congress and other institutions as appropriate, they were roomed never to recelve those rights. Candoll had been amply rewarded, at least in Tarbell's eyes, and nothing would ever core of any further demands. SO, too, had women been amply recompensed for theix lack of woting rights by the special comission, provided by God, of matemity and the rule over the roman's gphere.

In Tarbel" had overmooled the "one ctrmal fact that argument and agitation mould never accomplisin their goals. Too 
aggressive and too bitter, the suffragists had adopted the "dangerous practice" of espousing causes and supporting candidates that would benefit their cause and condemning all who opposed their cause, segardless of individual merit. Suffragists had failed to consider history, she wrote. Individual responsibility had always been of the utmost importance to women, but that responsibility was to be defined in morel terms. Most women dia not want and would never demand the Individual political responsibility of the vote as a right. Tarbell did not see the vote as a right, but as a privilege, and one which women would seek and obtain as they had other privileges: only "when they need it to accomplish some good for which they feel themselves responsible. "9

Tarbe11' I reactionary view that attempted to re-estiblish women in a separate wphere reflected the growing fight against woman affrage in the decades prior to the constitutional amendment enfranchising women. While she was perfectly willing to admit that the civil war, as was true of all wars, had "by necessity" changed the place of women in American society, Tarbell was not willing to let the transformation continue into the field of politics. Duty in the forn of necessity had moved women into the woriplace during the war. Their actions had been on the whole collective and properly motivated. It was wrong to cIaln the franchise because of one unusual individual who 
had been discriminated against even though she had acted with the same motivation. It was just as wrong to claim it because women's public roles had expanded and they could no longer be portrayed as being interested solely in domestic matters. Tarbel1's argument against carroll's attempt to demand recognition for her work outside her appointed sphexe, even if duty had led her there, was an example of the separate-but-equal repudiation of natural rights which was comnon among anti-suffragists. 10

Carrol.'s story faded gradualdy from public view. She was mentioned in a county history as "the most distinguished and brilliant woman Maryland ever produced. ${ }^{\text {II }}$ In 1925 , ehe Baltimore Sun ran an articie on hex, comparing her work with the supposed traliblazing incerest in business and politics of the "modern woman." In that article, Blackwel's book and Chandir:'s ariclo rere cleary the Bources used. Iemuel Fvans role in the drama was de-emphasized, and Iincoln was said to have gone to gi. Louis to implement carrol1's plan, an invention that would presumably lend needed credibility to her claim. 12 2n unconsciously patronizing article followed in 1934 by Dr. Milton shutes who deferded Carroil"s trespass on the ${ }^{\text {verboten" }}$ pain of military work "that has always been jealously reserved for the brilliant male! "13 "Somewhere a Iittle monument is missing" argued shutas, because carmoll

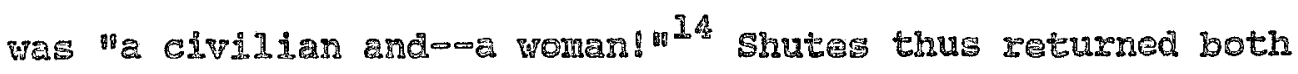


to carroll's argument that the military were too jealous to let her have her claim and to the suffragists' argument that held her sex responsible.

In 1940, Anne Carroll's story finally appeared in the popular press. Woman's Fome Companion, with a circulation of over three million readers, published a two-part serialization of Carrol1's career as a strategist. 15 The story of the "uninonored general of the civil war'l again accepted the validity of carroll's tale, again misdated her death, and again argued that her sex was the reason her work had not been properly rewarded. ${ }^{16}$ The piece, based on research by Marjorie Barstow Greenbie, added a twist to the last argument. Four years after the publication of the popular Civil war novel, Gone with the Wind, Greenbie reasoned that had carsoll been a romantic feminine figure who had deried Southern soldiers at the door, spied for the Jnion in the dead or night, or been a

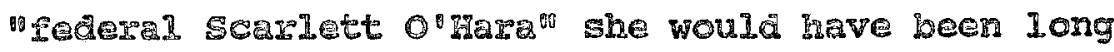
remembered and greatIy honored. But "hers was a man's role throughout." Because carroll wrote for the Union, advised President Isincoln and his cabinet, and designed military strategy, she did not fit into the acceptable romantic portrayal of women's mork auring the civil war. ${ }^{\circ}$ Her work wes too cerebral, her rigure too corpulant, her age too advanced to pexmit men to allow ber to becone a national bezoine. 
Marjorie Greenbie's research for the article went beyond the repetition of the congressional documents, Blackwell's biography, and the other suffragists' writings that earlier defenders had relied upon. She had found a treasure on the Eastern Shore of Maryland in one of Anne Carro1.' ${ }^{\prime}$ nieces, Nellie calvert Carroll, who remembered her "Aunt amne." In Pikesville, Maryland, she had found Ifatherine Cradock, another niece, who had kept her aunt's papers in her attic. Greenbie had persuaded her to place them in the reeping of the Maryland Historical society. Shortly after the magarine series was released, Greenbie's book on Carro11, My Dear Lady, was published. Although she had had time to use only a few of the documents she had discovered in her book, harjorie Greenbie would be joined by her husband sydney twelve years later in a second biography of carroll that promised to use all the documents. The two Grenbies would form team detemined to put theix version of carroll's story into the appropriate place in the history boofs ot america. 28

The Greenbies were not historians. Marjorie had a doctorel degree in philology from Yale: Syaney was what might be euphemistically termed a "popular" writer, author of ธuch bools: as Furs to Furrows: An Epie of Rugged Individualism, a defensive apology of manitest destiny as a positive good and a non-imperialist method of spreading Mmexican Givinimation. He also wrote a mble maries of 
travelogues on South and Central America as the "sister republics" of the United States. His works were panned by historical critics as stylish but insubstantial. ${ }^{19}$ The writing styles of both Greenbies were similar, not only to each other, but to Carroll's work as well. Hyperbole, exclamation points, and paranoia abound. "Could it be," Marjorie Greenbie began in My Dear Lady, "that there was a body of fact about the civil war, fact intimately concerning . . Iincoln and General Grant, which had been deliberately concealed? could it be that much of the history of the civil War is, in effect, untrue . . and has been allowed to remain so?" 20

Greenbie had begun her research in 1937 for her first book on Carrol1, after discovering Blackwe11's blography. A movie short called strange Glory which nentioned carroll she viewed as a sign "that the long silence about Anne carrold in witten history was bound soon to be broken." 21 creenble murriedly finished her book and published it in 1940 .

Py Dear Lady suffered from its guich completion. It is replete with errors: incorrect dates, names (Carroll's pamphlet Inion of the states is mistitled The Mmerican Union), and events. wen the epigraph taken from carroli's The Great American Battle was misgroted. Greenbie gave

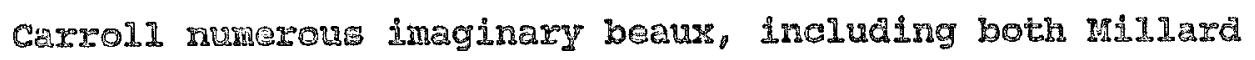
Findmore and James Buchanan. Family Iegend had mentioned 
both, in spite of Carroll's regard for Fillmore as a father figure. As for Buchanan, Carroll's political antipathy toward the Democrats would tend to preclude any romantic attachment. 22

Carroll was also given an access to Lincoln undreaned of by any of her previous biographers. Iivermore had written in My story of the War that Carroll saw Iincoln easily and that he had kept a "special file for her communications," but few biographers were willing to suggest that carroll could simply walk in and see Lincoln as she wished. His papers, in fact, contain an angry letter from Carroll demanding either an appointment or a reply after she had been kept waiting to see him for over a month. Greenbie, in contrast to earlier biographers, portrayed carroll as obtaining instant access at all times. 23 Iemuel Evans was marxied off by Greenbie, though there is no evidence he ever marriad. He became carroll's military attache to prevent ary hints of scandal or impropriecy on Carroli's part. 24 Greenbie stressed Caxsoll's femininity again and again in the text, though it proved dificult for her to comply with Nellie calvert's regrest that the biography be written in such a way as to "remove the false serse of strongmindedness conveyed by her works." carroli was to be feminine, sociabie, lady-like. Any cuggestion of carroll emerging from her proper sphere without the protective shiela of the jmage of the southem 
lady was inconceivable to her genteel niece. ${ }^{25}$ Faced with the contradiction between Calvert's demands and Carroll's work and personality, Greenbie began nobly, but soon gave up trying to assert her subject's femininity in hopes of convincing the reader of carroll's overall worth in spite of her inperious and independent nature.

She succeeded to a degree. Reviews of My Dear Lady carefully noted that carrold's intelligence and hard work for the Union had not interfered with her femininity. As was true in the nineteenth century, however, those who heard carrol's claim had a difficult time accepting it. They reviewed the work cautiously, granting its readability but awating mode conclusive evidence before accepting the validity of the claim. 26

Greenbie had no such hesitation. She believed the Carrol1 story completely. Hurrying into print with My Dear Iady, she had not used many of caxroll's papers she had retrieved from her niece's attic. She wanted more time for research and promisec her public that a closely-documented, les: speculative work would follow that would prove Carrol'"s Gaim beyond any doubt. world wax II intervened after 1500 copies of My Dear Lady had been run, and the book guicisly disappeared from print. 27 The story, however, did not aisappear. A radio play based on Grenble "s bouk was broedsast in June 1941, staring Agnes noorhead as Anne Carro11. Movile offers came from several studjos. 28 
Greenbie, off in the South Pacific with her husband sydney for the durati on of the war, left the story behind and returned to it about 1946.29

At the same time the Greenbies began their work on a more substantial biography, newspaper reporter Hollister Noble was writing a novel based on the life of Anne carroll. Entitled Woman with a Sword, it was published by Doubleday in 1948.30 Noble's novel, which shaved fifteen years and twenty pouncis off carrol1, incorporated the romantic ideas the Woman's Home Companion article had found lacking in Carroll's story. Carroll became a secret agent paid by the War Department and under the direct supervision of Iincoln, Stanton, and Benjamin Wade, chairman of the Comittee on the Contuct of the War. Lemuel Fvans became Carroli's fian'ce whom she would never marry because of what Noble delicately referred to as her "psychological problen" Noble"s apinion that carroll never found a man who could measure up to her fEther was a reasonable interpretation of her single state. He added, bowever, that career demands also Iimited Carrol1'G Ereedom of action. Those demands were not confined to simple personal fulfillment, but included the more important demands of duty to God and country. 31

Moble's novel was romantic and dashing and fairly well-written. It was also listorial Bamasy of the best-selling sort, with just anough sex ma wolence to malse it interesting without being o.fensive. Book revieners 
praised the portrait of the "petite, lovely and completely charming lady," whose "ingenious and brilliant mind" had saved the Union from annihilation. 32 Iife magazine told her story, calling carroll "Lincoln's Lady strategist" and only briefly mentioning that the work was fiction. 33 Adaptations of Noble's novel were performed on Cavalcade of America, and on the playhouse 25 broadcast of the Armed Forces Radio Network. ${ }^{34}$ The more times the story was told, the greater carroll became: a spy, a major-general, a "gecret war tactician." ${ }^{35}$ She met with Iincoln and stanton often to wastermind the strategical plans of the war. ${ }^{36}$ She deserved the country's thanks, but she had nobly kept her secret, so as not to denigrate the country's heroes. She died in penury (with dates as various as April, February, the 19th, the 18th, the 16th, 1893, 1894), an unsung heroine foiled by an ungrateful congress and sexist historians, and all that had happened to her was important and agstructive and romantic because bhe was a woman. The romantic appeal of a lone woman, fighting the military and political leaders of the time for recognition anc payment for her work, yet managing to rekain her attractive feminity throughout the battle, had enormous appeal for the gublic. Anne carroll would have been thrilled. At last her version of her story had been told. Granted, some of the biographers ambelisments were inaccurate la point whlch would nave concermed her not at 
a11), but all accepted unquestioningly the central issue: Anna Flla Carroll had designed and presented the Tennessee campaign plan to the United states government during the civil war and that plan had been directly responible for the winning of the war and the salvation of the Union. After the first flush of literary excitement at such a discovery in Amarican history died down, however, critical reviews and articles began to appear. F. Iauriston Bullard, Who had reviewed My Deax Iady favorably but reservedly in 1940,37 published a critical analysis of carroli's congressional claims. ${ }^{38} \mathrm{~A}$ contributing editor to the Iincoln Herald, Bullard argued that claims made by and for carroll were so incredible and so excessive that they demanded dippassionate ane scholarly investigation. Bullard concentrated on the inconsistencies and changes in text found in Carrol.1' congressional documents, the fortuitous additions, ano the credit that casroll had willingly given to scott in 1865, but had cried to belittle in her 1876 memorial to Congress. In the end Bullard accepted carroli as the one who had brought the Temnessee Plan to the attertion of military authorities in Washington, but argued that charles M. Scott, "an able and honest man" was its true author. 39

2 few months later, Caxrold's civil war pamphlets carne under scrutiny by lawyer Walter Himstrong. He found them to be the "מost and most persuesive contemporary 
rationalization of the theory upon which Lincoln acted." As for the military plan, while Armatrong did not deny tie validity of carroli's claim outright, he pointed out that Lincoln's dismissal of Carroll's propaganda proposal made it clear that he probably would have been unsympathetic to carrol1's military claims. 40

It was not until 1950 that a scholarly appraisal of Carroll's militar: claim was written. Kenneth P. Williams, working on a multi-volume history of the war, considered the claim in both his history and in a journal article. Carroli's claim, which willams thought "seemingly settled" by congressional inaction and her death, had been revived by Greenbie and Noble to such an extent that willians was determined to rule on its veracity once and for all. His interest was not entirely academic: williams, whom sydney Greenbie later referred to as "the bull in General Grant's pasture," was a great fan of ceneral Grant, and any attacl. or the general's abilities and accomplishments was automatically suspect. 41

Wlliams used the official records of the war to trace the actions in the western theatre to disprove Greenbie and Moble's versions of carroll's claim. Greenbie had not consulted the military records and had mistakenly credited CarrolI, Thomas A. Scott, and Iincoln with informing Grant of the plan in February as Gramal Halack ordered Grant up the Tempssae. Noble had explained the 
same event with a secret order from Iinvoln to Buell and Hal.leck. In fact, that move upritrer was suggested by Grant and Foote to Filleck. ${ }^{42}$ The official records did not: support Carrol1's alaim, Williams argued. As for her defenders, warie and scott, both were partisan politflians and inconsistent in their statements on her behalf. 43 since ingratitude was certainly uncharacteristic of Iincoln, Williams wrote, the fact that Iincoln turned down her propaganda proposal with such vigor further showed that she could not have been the author of a successful campaign undertaken such a short time prior to her proposa1. 44 . In the end, williams was not even willing to grant that Carrol1 had presented the same November 30 plan to Scott as had been printed in her congressional clains because the original document had never been found. ${ }^{4}$ In the 1lght of his analysis of the inaccuracies of bo:h Greenbie and Hoble, his caution was reasonable. He did not, however, exsmine carroll"g papers for the plan, merely the War Department records. since carroll claimed to have read the paper out loud to scott, it would not have been in the register of letters received anyway. Be that as it may, there was and $i s$ still no proof that the copy of the plan extant in carroll's papers today was the one she claimed she had presented to scott on November 30.46

WL1Lams a'd an excellent job of analyzing Carroll's cleim to prove the erraney of her assumptions regarding the 
effert of her plan. He also did an excellent job of provoking sydney and Marjorie Greenbie, who had been hard at works on a follow-up biography of Carroll. Anna Ella Carroll and Abraham Lincoln was due to be published in 1952, and a friend of Williams wrote to the University of Tampa Press for a pre-publication copy for williams. At that time, the press was run by sydney Greenble, and the carroll biography was its first publication. Williams' attack on Hy Dear Iady had roused Greenbie's wrath, and the polite request for a copy of the new biography was met with a childish refusal. "we don't give a whoot [sic] what Mr. Williams says or whether he sees it," Greenbie wrote, angry that Williams had accused his wife of inaccuracies. "In due course we will still take him on and show him a thing or two."47 This was the first shot in a series of nasty exchanges between Williams and the Geenbies on the valiaity of carrol1's claim and on the scholarly eredentials of her biographers. while the Greenies' second volume did make use of Carroll's papers and ajd benefit from interviews with family memberts who remembered her, their extravagant and unsupported claims detracted from carroll's reputation as a legitimate historical figure. ${ }^{43}$ The Greenbies were convinced that carroli's help was essential to Incoln. They accepted her pamphlets and petitions as prima facie evidence to assert that their interpretation of carrol1 was correct, that she had been denjed recognition solely because 
she was a woman, and that "wicked and malicious historians" were conspiratorially determined to negate her importance to the conduct of the war and to history 49

The Greenbies' book was painfully defensive in tone. It portrayed a fantastical version of events: Carroll supporting Iincoln as early as Iincoln's cooper union speech in February 1860, which the Greenbies claimed she attended as a member of the committee that selected lecturers for the platform; 50 Iincoln, stanton, wade, and carroll meeting together nightly in the War Department's telegraph office to plot strategy: ${ }^{51}$ Carroll so close to Jincoin and so much a part of his cabinet that the mpty chair in Francis B. Carpenter's painting of the cabinet at the time of the Emancipetion Proclamation was for her. ${ }^{52}$ Aside from these wholly imaginary and unsupposted conjectures, the book contained an inattention to isistorical detail that was characteristic of the Greenisies' work and that provided a field day for reviewers. Secretary of Wax simon Cameron was Simeon cameron tinroughout the text; photographer Mathew Brady was William F. Brady. President Andrew Jackson's famous toast at the Jefferson Day dinner in 1830 was mischoted, as was Samuel Morse's Biblical telegraph message that inaugurated the use of his invention. Not only was historical detail badiy damaged, but even literary nuances suffered fron the Greenbies' inaccuracies as magnolia trees burst "into wasy bloow" in March in washington, three months 
prior to their normal blossoming. 53

Most damaging of all to the Greenbies' text and to their version of Carroll's claim was the inventive terminology within their footnotes. Practically every controversial claim the Greenbies made had a footnote. But practically every one of those footnotes included the phrase: "This scene is synthetic." Where evidence was missing, the Greenbies argued, "psychology must step in and, with sleuth-1ike determination, re-establish the facts. 154 The Greenbies met criticism of their book in the Journal of Southern History, which was the only major historical journal that reviewed Anna Ella Carroll and Abraham IIncoln, with accusations that the reviewer was exaggerating and distorting the fow errors that existed "for his own ends."55 But sydney Greenbie saved his most acidulous replies for the criticism Kenneth Williams presented in the Iincoin Herald. For the Greenbies fat least for Sydney, since Marjorie tended to let her husband fight her battles), carroll and her claim had by now become less a symbol of man's inhumanity to woman than the failure of "distinguished egg-heads," "subterreanean" pundits, and "academic gauleiters" to appreciate the work of outsiders in the academic provinces. 56 As carroll had been an outsider in the nineteenth century, striving for recognition and legitimizetion by those in power, so the Greenbies fought for the recognition of thelr work by legitimate scholars. 
In large part, that resognition was denied. James G. Randall mentioned Carroll and the Greenbies' work favorably; ${ }^{57}$ Allan Nevins mentioned Carroll's claim as well, but pointed out the additional evidence that she was not the first nor the only one to concelve of the Tennessee River campaign. 58 Roy P. Basler included a letter from Iincoln to carroll praising her "address to Maryland" in his sine-volume edition of Lincoln's papers. 59 But by and large, the academic community found williams' condemnation of carroll's claim convincing and substantially suppozted by the official Records. Even williams' additional, somewhat specious, argument was accepted: it vas unnecessary to give Carroll credit for the Tennessee Plan because even if she had thought of it, it was so obvious it had doubtless occurred to every military mind. 60

Resigning themselves momentarily to the lack of scholarly appreciation, the Greenbies returned their attention to the popular press, where praise for Noble's work was still strong. Hallmark Hall of Fame television production, based on Noble' novel and starring Iayne Meadows, had been broadcast in February 1952. Noble had also made a distribution agreement with sears and Roebuck. They had sold thousands of copdes of Woman with a sword through the1r People's Book Club. ${ }^{61}$ If the Greenbies could not obtain :cholarIy regard, they were determined to protect thein story of Anne Cartoll firom pirates such as Noble who 
were making a fortune. On July 21, 1954, the Greenbies filed a copyright infringement suit against Noble, his publisher Doubleday, Sears ard Roebuck, and against those Who had sponsored the shows based on Noble's book: Dupont, the National Broadcasting Company (NBC), Hallmark Cards, Cavalcade of America: Batten, Barton, Dunstine \& Osbozne, who luad produced a 1949 radio show; and Foote, cone and Belding, producers of the Hallmark Hall of Fame version. 62 The civil case was before the courts for nearly three years and produced over 1000 pages of testimony. Noble comitted suicide just prior to the suit's filing, and eventually onIy his publisher and Sears and Roebuck remained as defendants. The judge ruled against Marjorie Greenbie, finding that Carroll's story was "derived from comon sources and nacerials avaidais to to al1."63 since listorical racts contained in govemment publications were not subject to copyright: and since Greenbie had failed to prove that Noble had copiad from her book rather than using the original source material avallable on carxol1, no copyright infringement existed. ${ }^{64}$ Furthermore, since Greanie's first book had not been a commercial success and had been out of print for six years before Nobie published the novel, Greenbie had not been harmed financialiy, and could recover no danages. As for Noble" "parallel language, incidents, ideas and justaposition of words and

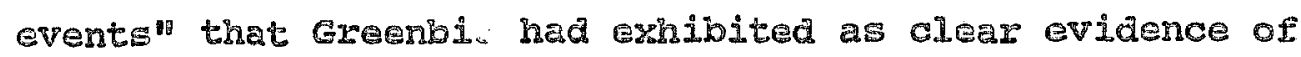


Noble's plagiarism, the judge ruled that "similarity of phraseology" did not amount to a copyright infringement. 65 "Against this Janus-faced decision" the Greenbies appealed, but withdrew after a settlement offer, citing the cost of pursuing an appeal. 66 Infuriated by the 1oss, sydney Grenbie wrote a book about the writing and the plagiarizing of the story of Anna Flla carroll. The book was valuable for additional information on carroli's Iife as it recounted the interviews held with her family. Greenbie was more interested, however, in revealing that Noble's "sole original contribution to the life of a very great person was to falsify hex position and hex Mmerican ideals by making her and her distinguished associate, Judge Evans, into commo dsts.

MobIe's bools, ranted Greenbie, was a collaboration by comuniste at Doubleday to "propagandize "old man Mary" and to make money. 68 Fvidence of the second was a giver.

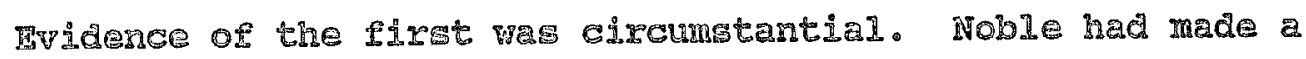
jarring reference to Carroli reading Marg"s civil war sssay, and he had persisted in referring to the Radical Repulicans as the "Ied Republicens."69 He had also included a scenc wherein Bvans called for restructuring of Fsoeican capitalist soclety away from the "feudal strangle" os Sorthern planters that hat rested on the "exploitation of man by man in bise torn of ragial slavery. ${ }^{70}$ But such mnor incidents of mexyigte ghilosophy tended to be burded by 
the sweeping romance of Noble's novelization. The book was not, as Greenbie preferred to view it, "a case of cultural adultery. . . the rape of one of the great stories of Americas history by communists for communist onds." 71 Such Ilbelous vituperation kept any publisher from bringing out Greenbie's manuscript, and in the end he had it privately printed. But the Greenbies' championship of Carrol's cause might have had some effect on the scholariy world, for even though williams had pretty well destroyed thes version of hes claim, her story did not disappear from view entirely. She appearea again, tale intact, in a history of women in the war and in a juvenile biography. ${ }^{72}$ One of bex Civil War pamphlets was reprinted in a scholarly collection of much publications and she was listed in the giogrephical airectory, Notable American womer. 73 In the 1.9705, as women' history began to achjeve momentum and notice as a legitimate field of historical incuiry, her entire career was given scholarly attention, fres from the partisanship and Iiterary vindictiveness that had characterized earlier worls.

Chaxles Mc6001 snyder discovered approximately fifty letters between carrold and Millard Filmore and, in 1973, presented his findings about Carroli's career in the 1850s, characterifing her accurately as a political strategist, but

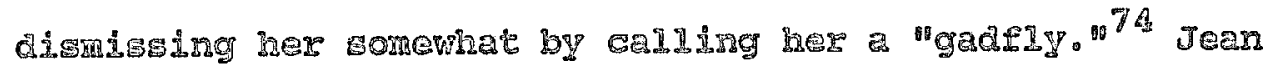
Baber, historian of Rarylanc politice 1 s the nineternth 
century, analyzed carroll's writings in two of her texts, including a quantitative textual analysis of Carroll's The Great American Battle as a prime example of Know-Nothing Iiterature. 75

E. B. Iong, research director for civil war historian Bruce Catton in the 1950s and 1960s, took on Carroll's military clain once again, but with a less condescending and hostile attitude than Renneth williams had evinced. He iully expected his attempt would "undoubtedly arouse the same acrimonious controversy that has surrounded this maryland 1ady for over a century," but was willing to take his chances. ${ }^{76}$ Iong granter that carroll had written the Plan in her papers that WiIIiams had dismissed, and that she had presented the plan to the war Department. He also pointed out that those "with political and social axes to grind" had used carrol1's story for their own purposes. 77 Iong reasoned, as had willims, that the design of the plan was so obvioug that giving any one person credit was a bit absura. The validity of her claim aside, Iong did not thing Carrol1 was a "malielously hidaen" figure in history, but merely a "competent, capable woman," a "minor figure with a fascination all hex own, but with slim importance."78

whis last assessment of Carro11 must be reconsidered, however, in the light of her worle outside her GIdis of widitary strategy. Carroll had used her sicill as a writer to do the work she wanted in a field she loved. As 
a woman, her options in politics were limited. So, in the beginning of her career, Carroll had developed a compromise methodology to fulfill her goal of participating in political activity. Writing was one of the very few socially acceptable activities outside the home for upper-class women, particularly southern women. Even that activity was Iimited by the image of the "Southern lady." The pervasiveness of that image meant that to achieve social acceptability for any activities outside the norm, the woman working had to do so within the cultural framework that existed. Carroll accepted the validity of the dominant assumptions of her culture at first: the importance of poljtios both professional and personal, of ambition and achievement, and of the idea of the womanly sphere. Her writing: reflected those assumptions. And because her work reflected those assumptions rather than doing battle against them, Carroli achieved one of her major goals: to have her work read and taken seriously by politicians. 79

At the arme time, the cultural imperative of the Southern lady demanded that whe prosent her work in a very specific manner. For Carroll, the image"s cultural denand of selflessness would not take the usual and expected form of volcelessness amd I lstering to those who had something to Say worth Iistering to fi.e. white male politicians and preachergy. Caxrol1's selflessness began as anonymity. Her un?mom voice cowld present ideas important to her in a 
designedly non-threatening manner. 80 Carroll's method as she began her career did not threaten to challenge the male-dominant power structure and try to change it. Nor did it threaten her own sense of feminine self. She was very aware that she was a female operating in a male sphere. But with duty as her motivation and anonymity or, later, self-effacement and apology part of her by-line, she reassured her readers. Perhaps carroll knew claiming a right to participate fully in politics would raise a backlash that could shut her out completely. 81

carroll commicated her ideas through print and personal contact, through petitioning rather than confrontation. Thess three characteristics of hex style are typical of what historlan IInda Kerbex has labeled "prepolitical" behavior: the acknowledgment of inferiority (the apology, the rhetoric of humility (the assurance that only duty had drawn carroll into political matters and away from her more appropriate rolel, and the individual nature of the act of petitioning parroll wrote alone, even when the ideas she presented reze shared by many. 82 But for Carrol, her actions as writer, lobbyist, cxitic, hostess, travel1er, saleswoman, or strategist, were unquestionably political acts with politicel goals in mind, be they publication, patronage positions, or simple acceptance of the value of her opdinton and Intelligence.

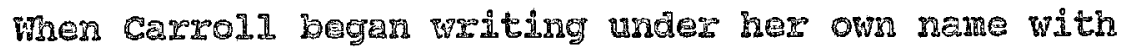


no apology, however, and when she filed for her claim and entered the public arena, her methodology had changed. Filing her claim and gathering support from suffragists represented more than a desire for money and for recognition for something she thought she had done. They were also acts that forever broke her Iink with the role of a proper Southern Lady. Because she was no Ionger anonymous, she was no Ionger voiceless. By entering the pubilic sphere, carroil confronted the institutions and cultural imperatives that bad groved so unaccepting of her desire for recognition. To place carroll into a historical category that is not a southern lady is difficult because of the Individualistic natro of her work. She was not a reformer. an abolitionist or a proto-feminist of the type identifiable fron 1830 to 1860 . She did not join voluntary associations. She was not a suffragist, although she did not hesitate to use their strengths to support her cause. She vas not an upper or middI - CIass famiy-oriented woman preserving the hearth sor a hard-wolging husband and embracing the cult of dowesticity. Mor was mhe an unarried daugher working until she was married and thu proparly taken care of. 83

If categorized at al1, Carroll was a bit of a VI.ctorian bluestocking, albeit a sociable one, but enraptured by books and educetion. A prescriptive writew. her woris: reflected the assumption that universaI noraI principles could be conceptualized, understood, and acted 
upon in the same manner as physics or chemistry. Feeling free to write on all sorts of subjects, Carroll exemplified the lettered women and men of the victorian era in America who were anateur experts and believed learning and scholarship were inclusive rather than exclusive, and should be shared with others, whether as commentary or advice. ${ }^{84}$ The fact that carroll never married was surprising. She was an attractive and vivacious woman of a distinguished family. But she never semed inclined to give up the relative freedom a single woman had over a marrided one in nineteenth-century America. Her work as a writer help support her through much of her life and enabled her to care for her father, a "congenial presence [which] seemed to be a11-sufficient for her." 35 by caring for her father, she could fulfill the domestic role which society demanded of her, whie retaining her independence. She was not without men in her 2ife, but her works was her passion. Her surviving letters to politicians and family alife contain Iitt 1 of the domestiolty that was the usual lot and focum of nost women during this period, when the proper sphere of womanly activity became the cult of domesticity. Instead, her letters and those she received were full of political news and gossip, of reports and opinions, of rumors and plans, of artides and editorials. She was treated by the vast majorlty of minor politicians who wrote to her as a woman with a great deal of political and legal acumen and a 
certain amount of influence. The former was evidenced in her published work as well; the latter was a less tangible and certainly overestimated quality. Defining carroll's historical importance has been Iimited to one-sided stands taken in support of or in opposition to her claim to authorship of the Tennessee campaign. Fortunately, historians in the last twenty years have become aware that the past is very complex. Within that complexity, Carroll begins to assume her place nore clearly. she becomes, not a simplistic figure of downtrodden womanhood that historians have either conspired to consign to oblivion or to save from obscurity, but rather a woman of active political involvement, laboring for causes she belleved in, using the methods available to her. 86 as an historical persona, carroll has becowe what she called for in The Great American Battie: not a Joan of Arc, but a faithrul and true woman, neither neroine nor fool, but an Anerican woman who could stand in her ow shoes. 87 Those shoes wight be a different size than she had plamed, a different style, planted in a diferent place, but they are at dast her own. 


\section{Notes}

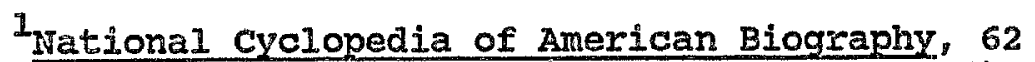
vols. (New York: James T. White \& Co., 1893-1984), $5(1894): 193$.

${ }^{2}$ Albert Gallatin Ridale, Recollections of War Times: Reminiscences of Hen and Events in Washington 1860-1865 (New Yorj: G. P. Putnam's Sons, 1895), P. 190, 193.

${ }^{3}$ Sarah EIIen BIackwe11, Iife and Writings of Anna E11a Carrol1 (Washington, DC: Judd \& Detweiler, 1895): Woran's Journal 26 (19 January 1895):21. "The pamphlets form a valuable contribution - . and an able dissertation on the principles of the constitution. As such re recommend it for study by the equal suffrage olubs and clubs for political study."

4ucindia B. Chandler, Mnna Flla Carrol1: The Great Unrecognizel Geniug of the War of the Rebeliton, "Godey's Magazine i33 (September 1896):255.

5.Ibic., p. 257

Congressional Record, 55 th congress, 1st session, $1897,2896$.

${ }^{7}$ Sarah ELlen Blackwell, Iife of a Miltary Genius: Anma Ella Carrol1 of Mary Iand (Juda \& Detveiler, 1891), pp. 150-163 gives some 1der of the rumbers of wonen that wrote on behalf of camoli'g cause. see also articles, letters and even poetry in issues of the Woman's Journa? fron 1885 through 1896. Carroll's story was also puls ished in Americen Momen, ed. Frances E. WIIlard and Mary A. IIVerrorer.2 volw. (New York: rast, Crowell \& Irixlpatrids, $1897:$ reprint ed. Detroit, Michigan: cale Research Co., 1973), 1:1.53-154。

Ida M. Tarbe11, MThe Anerican Foman: How She Het

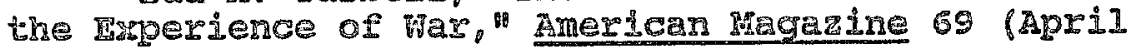
1920):81.

TH1d. 9p. 801-802,814.

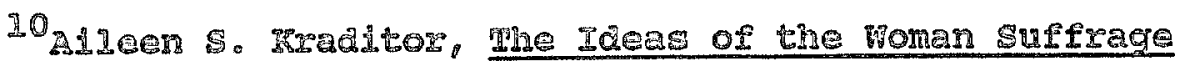


Movement 1890-1920 (New York: Anchor Books, 1971), pp. 16-17, 21-22; Nancy Woloch, Women and the American Experience (New York: Alfred A. Knopf, 1984), pp. 337-343; "Ida M. Tarbe11," Notable American Women, ed. Edward T. James, 3 vols. (Cambridge, Massachusetts: Harvard University press, 1971), 3:430.

${ }^{1 I_{\text {Elias }}}$ Jones, Revised History of Dorchester County, Maryland (Baltimore: Read-Taylor Press, 1925), p. 298.

${ }^{12} \mathrm{May}$ Irene Copinger, Maryland Woman Influenced 0. S. Destiny," Baltimore sun, 11 october 1925. Carroll's death was misdated as 21 February in this article, which also credits her with a biography of General Joseph Warren.

${ }^{13}$ Dr. Milton H. Shutes, "Meet an Unheralded Hexoine," Nationa I Republic Hagazine 22 (November 1934):3-4.

${ }^{14}$ Ibid., p. 34.

15 "MY Dear Lady" "Woman's Home Companion, February and March 1940 issues [see note 16 below]. Woman's Home Companion, edited by Gertrude $B$. Iane, was the number one women's magazine in the United states in 1937. See

"Gertrude B. Irne," Notable American Women, 2:363-365.

$16_{\text {MY Dear Lady }}$ " Woman ${ }^{\circ} \mathrm{s}$ Home Companion

67 (February 1940):13.

17 Ibid. p. 14 .

18 Marjorie Barstow Greanbie. My Dear Lady: The Story of Anne Ella carroll, the "Great unrecognized Hember of Iincolri's Cabinet" (New York: McGraw-Hill, 1940): Sydrey and Harjorie Barstow Greanbie, Anna rlla Carrol1 and Abrenam Iincoln (Manchester, Maine: University of Tampa Press in cooperation with Faimouth Pubilshing House, 1952!, p. vili.

19 See reviews of Greenbies wort in the American Fistorical Review 32 (October 1926):172-173: and American Historical Review 45 (July 1940): 972, wherein the reviewer of surs to Furrows remained "completely baffled as to why the bools mas ever written."

20 Greerble, ry Dear Lady, pr. Vi-vii.

2IIbid.,p. svi. Strange Glory was released by Metro-Goldmy whay in 1938. The director was Jaccrues Tourneurs, the historieal compilations were made by Charles

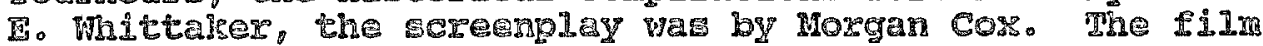


does not appear to have survived to the present. Any Turin [Archivist, National center for Film and Video Preservation, American Film Institute, Washington, DC] to author, 17 March 1986.

22 Robext J. Scarry, Millard Fillmore: The 13th President of the Inited states (Moravia, New York: Robert J. Scarry, 1982), p. 5 .

${ }^{23}$ Mary Livermore, My story of the War (Hartford, Connecticut: A. D. Worthington, 1889/, po 174 ; Greenbie, My Dear Laciy, passim, especially pp. 260-261: anna Ella

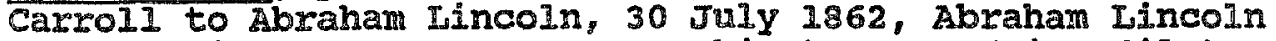
Papers, Iibrary of Congress, Washington, DC (microfilm).

${ }^{24}$ Greenbie, My Dear Lady, $p .111$.

25 Ibia., PR. Kii, 39.

26. Iauriston Bullard, "Anna Ella Carroll Career Persuasively, Eloquenty Told, Boston Herald, 19 october 1940: Iyman Beecher stowe, "In Iincoin's Ititchen cabinet, " New York Times Book Review, 8 December 1940: RaIph

Thompson, "Boolss of the Times, New Yor] Times, [n.d.]: all clippings preserved in the Anna Ella Carroll pile, National American Woman Suffrage Association Papers, Iibrary of Congress, Washington, DC.

27 Sydney Greenbie, suit with Red Iining Penobscot. Maine: Traversity Press, $1958 /, \mathrm{p}, 47$.

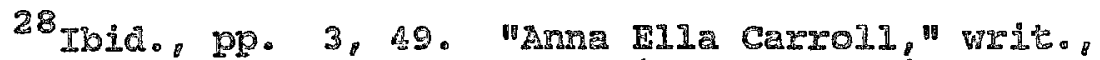
Robert Tallman, Cavaleade of MmerLea, MBC Radio, 2 June 1941.

29 Gaenbie, Sujt, p. 56 .

30 HOIIIEter Moble, Woman with a Sword (New Yoris: Doubleday, 2948), pp. 3-5. Doubleday issued a separate pamohlet which reprinted Noble's bibliography and sources. apparenty for distribution to bookstores.

3I Ibid. p. 408.

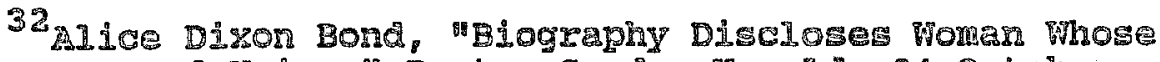
Strategy saved Union, "Boston Sureay Herald, 24 0ctober 1948, olipging is Carroll Fide, IFAWSE Papers.

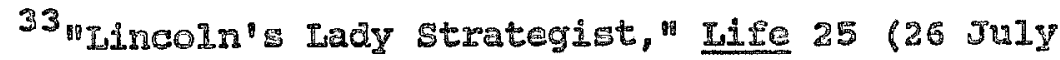
$1948): 101-102$. 
34"woman with a Sword," writ., Hollister Noble, Playhouse 25, Armed Forces Radio and Television Services, n.d. [1974 rebroadcast]; "Woman with a Sword," writ., Hollister Noble, Cavalcade of America, adapt., virginia Radcliffe, NBC Radio, 23 May 1949.

${ }^{35}$ Herbert Allen, "New Light on Lincoln's 'Secret' War Tactician, "Boston Herald, 2 February 1949, clipping in Carroll File, NAWSA Papers.

36 H. F. Heal, "Secret Heroine of the Civil War," coronet 26 (May 1949):148-152.

${ }^{37}$ see Bullard, "Anna Ella Carroll Career," note 26 above.

${ }^{38}$. Lauriston Bullard, "Anna Ella Carroll and Her "Modest' Claim," Lincoln Herald 50 (October 1948):2-10, 47.

39 Ibid., p. 10.

40 Walter P. Armstrong, "The Story of Anna Ella Carro11: Politician, Lawyer and secret Agent, "American Bar Association Journal 35 (March 1949):199.

$4 I_{\text {Kenneth P. Williams, "The Tennessee River Campaign }}$ and Anna Ella Carrol1. Indiana Magazine of

History 46 (September 1950): 223 ; Greenbile, suit, p. 60.

42 williams, "Tennessee Campaign," pp. 230-234. See Chapter 5 above.

$$
\begin{aligned}
& 43 \text { Ibid., pp. } 235 \times-237 . \\
& { }^{44} \text { Ibid., p. } 247 . \\
& { }^{45} \text { Ibid. pa } 248 . \\
& 46 \text { Anna Ella Carroll to Thomas } \mathrm{A}_{\text {. Scott, } 10 \text { January }}
\end{aligned}
$$
1862, Anna Ella Carroll Papers, Maryland Historical Society, Baltimore, Maryland. This document contains the Hovemoer 30 plan and an appended letter reiterating her advice, dated 10 January 1862 , that carroll persistently misclated in her petitions and memorials as 5 January 1862 .

47 sydney Greenbie to Monroe F. Cockrell, n.d., reply mitten on letter, Monsoe 7 . Cockrel I to University of Tampa Press, January 1852, Honroe Fo Cockrel1 Papers, William R. Pexkins Ijbrary, Duge University, Durham, North Carolina. cockre11, a friend of williams, was a businessman whose 
avocation was Civil War history.

${ }^{48}$ Avery Craven, "Review," New York Herald Tribune Book Review, 26 October 1952.

${ }^{49}$ Greenbies, Anna Ella Carroll and Abraham Iincoln,

p. 505. Hereafter cited as AEC \& AL.

50 Ibid., p. 193.

5I Ibia., pp. 366-375。

52 Ibia., pp. 400-404.

53 Ibia., pp. 140, 91, 233.

${ }^{54}$ Ibid., P. 505.

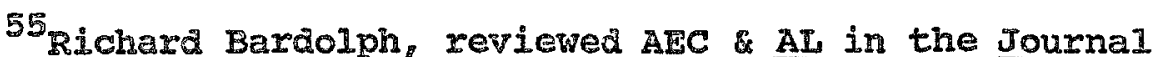
of Southern History 18 (November 1952):511-513. See also Syaney Greenbie to Editor and Richard Bardolph to Editor, Joumal of Southern History 19 (November 1953):549-551.

56 M[arjorie] B. G[reebie], "The Making of a Best seller "epigraph to Sydney Greenbie, suit: Greenbie, Suit, pp. $124-125$.

57J. G. RandaII, Iincoln the President, 4 vols. (New York: Dodd, Mead, 1945-1955): 2(1945):66-67.

58 Allan Nevins. The War for the Union: war Becomes Revolution, $1862-1863$ (New Vork: Charles Scribner's Sons, 1960). PP. 15-16.

59 Abraham Iincoln to Anne Ella Carroll, 19 August 1862, in The Collected Worlse of Abraham Lincoln, ea. Roy P. Bas Ier, Vols. (New Brunsvigh, New Jersey: Rutgers Univer:gity Press, 1953/, 5:381-382, This letter, mritten a fer days after Carroll's angry reply to lincoln's refusal of her propagande proposition, was cited by the creenbies to prove that Lincoln' refusal was caused by ill temper and that Incoln and carroll guiakly returned to their close companionship. The letter is not an original, but a copy which Carroll enclosed in a letter introducing herself to

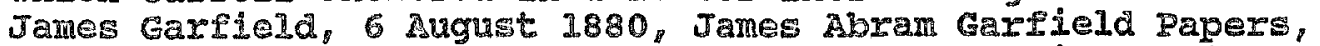
Hibrary of congress, wasnington, DC. The copy is not in her hand, wilch makes diss authenticity less suspect, but it is really just a polite note to a citizen who had done worls for the behalf of the Inion. Iuncoln, Basler suggested, was simply trying ter sootine carrolig anger at being refused. 
After all, her constitutional pamphlets had supported Lincoln and had been distributed by the administration. Iincoln's action was simple courtesy, no more. Carl Sandburg also mentioned Carroll's pamphlets briefly in Abraham Iincoln: The War Years, 4 vols. (New York: Harcourt Brace \& CO., 1939), 1:410-411.

60 Kenneth P. Williams, Iincoln Finds a General, 5 vols. (New vork: Macmillan, 1949-1959), 3(1952):456; see a.lso vol. $4(1956): 455-457$.

61"Woman with a Sword, writ., Hollister Noble, Hallmark Hall of Fame, NBC Television, 10 February 1952. A copy of this performance, which featured Jayne Meadows as Anna tila Carroll, survives on kinescope at Radio and Television Archives, University of California at Los Angeles, Los Angeles, California. Greenbie, Suit, P. 121.

62 Ibid. p. 138: Greenbie v. Noble, et al, united States District court, Southern District of New York, Civil 94-300, National Archives, New York Branch, Bayonne, New Jexsey.

63 Ibid. The Honorable Richard Levet, "Opinion," p. 44: Greenbie, Suit, p. 138 .

64 Levet, "Opinion," Pp. 45-48.

65Ibia., P. 54.

${ }^{66}$ Greenbie, Suit, p. 219.

67 Ibid., pp. 220-221.

63 IDid. PP. 224-225

69 HobIe, Woman with a Swora, pp. 291, 332.

70 Ibid., pp. 333-334.

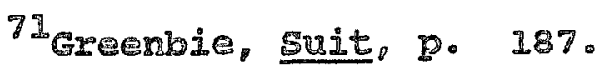

72 Agath Young, The Women and the crisis: Women of the North in the Givil War (New Yorlz: MoDowell, oblensky"

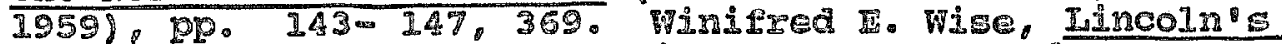
Secret weapon (Nev York: chilton Co., 3961) drops a number of years from carroly ${ }^{\circ}$ age as Noble had, and tries rad damely to distinguish between the Mmeriean Party asz the more pejoratively denominated Know-hothings as two entireIy saparie organdevtions. An earider juvenile article nes 
Kenneth M. Gould, "Iincoln's Unknown Soldier," Senior

Scholastic 69 (9 February 1956):16. Carroll's tale was also told in otto Fisenschiml, The Hidden Face of the Civil war (New York: Bobbs-Merri11, 1961), pp. 74-82. isenschiml's conspiratorial approach to the history of the civil War would no doubt have appealed to the creenbies.

${ }^{73}$ Anna FIla Carroll, "The Relation of the National Government to Revolted Citizens Defined," in Union Pamphlets of the Civil war 1861-1865, ed. Frant Ireidel, 2

Vols. (Cambridge, Massachusetts: Belknap Press of Harvard

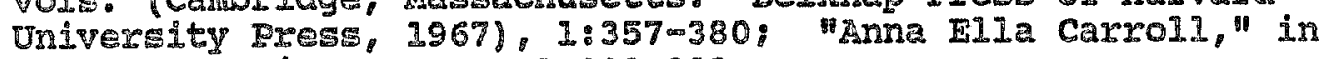
Notable American Women, 1:289-292.

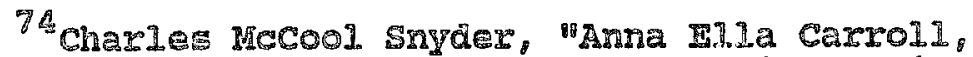
Political Strategist and Gadfy to President Filimore," Maryland Historical Magadine 68 (Spring 1973):36-63.

75 Jear Pa. Bajar, The Politios of Continuity: Maryland Political Parties from 1858 to 1870 (Baltimore: Johns Hopkits University Press, 1973), p. 187: Jean H. Baker, Ambivalent Americans: The Rnow-Nothing Party in Maryland (Baltimore: Johns Eopking University Press, 1977), pp. $35-36,156-357$.

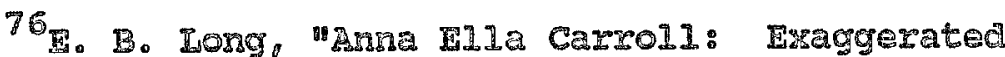
Heroine?" Clvil War Fimes IIIustreted 14 (JuIy 1975):29.

77 Idid. P. 33. Long was no dombt referring to the Grensie lawguit, an whion he was called in aw an expert on Lincoin and Lincolnaria, Greenie had umkind1y charawterized him as a "Bonga Thrower for the lords of the Lincoln industry " poet laureate of african chiefs whose task was to whisper praise in the ohete ear thase times a dey and to find a way to praise aII his netions, even those that had failed. Greensole, suit, p. 192.

$78_{\text {Long, "Anne EIIa Cario1," }}$. 35.

79 Anne Firor Scott, whe Southern Iady: From Pedestal so Politios, 1830-1930 (chicago: Univergity of Chicago

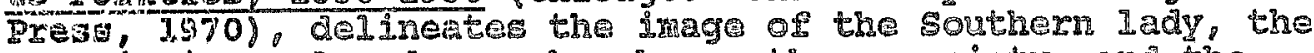
restrictions placed upon ner by wouthern society and the ways 1 whish momer were politically aotive whide still working within that restrictive tramework. See also Anse Goodwy Jones, "Gouhnern It terary women as Ghroniclers of Southern Life, "in Sar, Race and the ROLe of Women in the

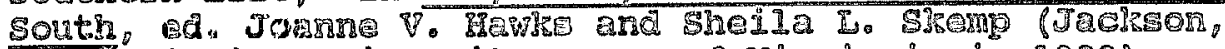

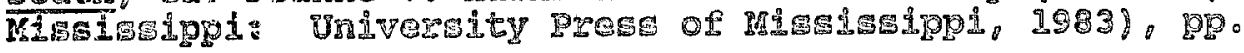


$84-85,81,92$. Jones uses Mary Boykin Chesnut as one example in her study of the restrictions, both social and psychological, under which southern literary women worked.

${ }^{80}$ Jones, "Southern Literary Women," p. 92.

${ }^{81}$ Anna E1Ie Carro11, Review of Pierce's

Administration: Showing Its Only Popular Measures to Have originated with the Executive of Millard Filimore (Boston: James French and Co., 1856), pp. iili-iv.

82 Ifinda IFerber, Women of the Republic: Intellect and Ideology in Revolutionary America Chapel Hill, Worth Carolina: The Institute for Early American History and Culture by the University of Jorth Carolina Press, 1980), chapter 9, exaulnes women's political methodology prior to enfranchisement. See also Mary Eeth norton, Liberty's Daughters: The Revolutionary Experiance of American Women, 1750-1800 (Boston: Iittle, Brown \& Co., 1980), chapter 6 .

${ }^{3}$ Scott, The Southern Lady: Gerda Lerner, The Grimke Sisters from south Carolina: Pioneers for women's Rights and Abolition (New York: Sahochen Books, 1967); FIIen Carol Dubo:s, Feminism and Suffrace: The Fmergence of an Independent women's Movement in America, $1848-1868$ (Ttnaca. New Yorr: Cornell University Press, 1978)。 Anre Firor Scott, frasino the InviejbIe woman VISible (Uimane, ILILnois:

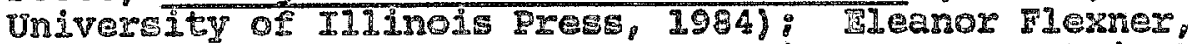
Century of gtrugge: The Woman's Rights Movement in the United States (New York: Atheneum, 1973). One reason Carroli ald not join a voluntary association may have been lack of opportunity. Religious reform societies, wuch as the Areroican Home IRIssionary society that would have appealed to carroll were neariy monmeristent in Marylana. Sae James S. Van Hes:, "EConomic Development, Sostai and CuIture I hange: $1800-1850$, ol in Haryland: A History,

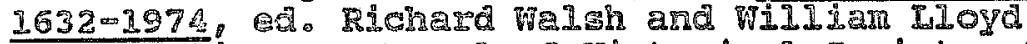
FOR (BeItImore: Rarylard Higtorical Society 1974),p.

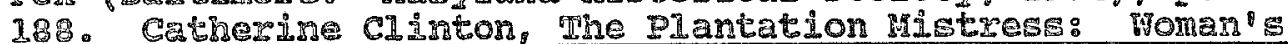
World in the 01a South (Hew Yorls: Pantheon Boolps, 1982 ) and Mary P. Ryan, Crade of the Hadle class: The Family in oneida County, hrev Tork, $1790-1865$ (Cambridge: Cambriage Universt:y Press, 1981) both aiscuss the status symbolically genereted by a leisured wife wino could create anctuan at

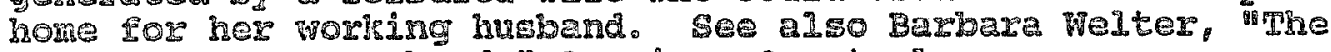
Cult of True Tomankood, ${ }^{\text {g9 }}$ Merdean Quarterly

18 (1966):151-174, Eor a delineation of the culs $s$ prescrivive cherateristios. Thomas Dublin discusses the

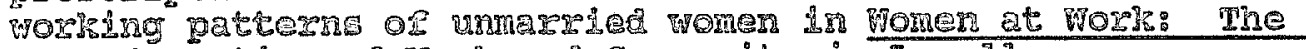

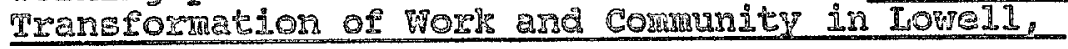


Massachusetts, 1826-1860 (New York: Columbia University Press, 1979).

${ }^{84}$ Daniel Walker Howe, "Victorian Culture in America," in Victorian America, ed. Daniel Valker Howe (Philadelphia: University of Pennsyivania Press, 1976), pp. 21-23, 14 .

${ }^{85}$ Blackwell, Iife, I:22。

86 Jean Gould pales, "co-laborers in the cause': Women in the Ante-belium Nativist Hovement" civil War Fistory 25 (June 1979): 119-138.

67 anna Flla Carrol1, The Great Anerican Battle: or, the contest Between Christianity and Political Romanisin (New York: Mi1101, Orton \& MuIIigan, 1856/, p. 28. 


\section{BIBIIOGRPPHY}

Notes on sources: The sources listed in the Bibliography are primarily those cited in the text. Additional sources which were used extensively but not cited directly are also included carroll's works and worls on her life have been 1 isted separately.

\section{Manuscript Collections}

Baltimore, Maryland, The Maryland Historical Society. Mnna Tila Carroll Papers. Anna EIla Carrol. Papers: Carrol1, Cradock, Jensen collection. Thomas Holiday Hidrs Rapers.

Cleveland, Orio. Western Reserve InIstorical sociecy. Elisha whittlesey Papers.

Duriam, Morth Carolina. william R. Perkins Iibrary, Duse University. Monroe F. Cockrell Papers.

Fouston, Teras. Rice University。 Jefferson Davi: Papers.

New Haver, Connecticut. Xale university. Aaron Columbus Burer Pagers.

New Yorjs, New York. Public Iribrary. Anthony Autograph Collect2on.

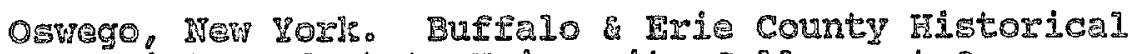
society and State University Collage at Oswego. 


\section{Millard Fillmore Papers.}

Philadelphia, Pennsylvania. The Historical society of Pennsylvania. Frederick Dreer collection.

The University of Pennsylvania Archives. Biographical Folders collection.

Richmord, Virginia. Virginia Historicel Bociety. Mason Family Papers.

Rocheste: Few York. Rus Rhees Library, University of Rochester.

Viliam Henry Seward Papers

Thurlow heed Papers.

Syracuse, New York. The George Arents Researeh Iibrary, syracuse University。

Gerrit Smith Collection.

Washington, DC. Tibrary of Congress.

Blackwe11 Family Papers.

Brecliniage Family papers.

Carroll Family Papers.

Salmon Portland chase Papers.

John H. Clayton Papars.

Grover Cleveland Papers.

Thomas Corwin Papers.

Hamilton Fish Papers.

James Abram Garfeld Pagers.

Abrahan Lincoln Papers.

Wi11 Iar Learned Narcy gapers.

Wational American Woman Suffrage Association Papers. Gideon welles Dapers.

Thurlow Weed Rapezs.

Washington, DC. National Archives.

U. S. Department of the Intertor. Record Group 48. "regords of the office of the secretary of the terjor Relating to the suppression of the African \$lave Trade and Negro Colonizeton, 1854-72."

U.5. Department of State. Recora Group 59. "Desa patches From United States Ininister to Honduras, $1861-1873.97$

0.5. Departnent os Stete. Record Grovp 59. "Irtters of Apolication and Recomendation Duxing the Administration of 0.9. Grant, 2869-1877." 
U.S. Department of the Treasury. Personnel Applications.

U.S. War Department. Anna Ella Carroll File, Record and Pension office.

\section{Govermment Documents}

Amnapolis, Maryland. Mary dand state Archives, Hall of Records. Dorchester County Probate Records. Governor: ${ }^{\circ}$ Letter Bools. Droceding of the Governor. Somerset County Chancery Court Records. somerset County Deed Book.

Congressional Globe, $1861-1873$

Congresing Ron Record, $2874-2897$

U.5. Congress. House. Committee on Military Affairs. Anna HIla Carroll: Report to Accompany Bill F.R. 7256. 46th Cong., 3a sess. H. Rept. 386. พ⿴囗十ำington, DC: GPO, 1881.

U.S. Congrews. House. Commtte on militay Affairs. Memorial of Mma TIII Carroll, of Maryland, Praying Sor Compensation Lor Services Rendered to the United States During the Late Civil War. 45th Cong. 2a sess, H. Mis, Doc. 58. Washington, DG: GPO, 1878.

U.S. Congrass. House. Committee on Military Affairs. Petitjon of Anma Ella Carrol I for Compensation for Services Rendered to the Mar Departanent during the Late War. 4tth Cong. 2st sess. Ho MIs. Doc. 179. WashingLO, DC: GPO, 1876 .

U.S. Congress. Senate. Comittee on the conduct of the Wax. Report of the Joint Committer on the Conduct of the War. 37 tir Cong. 3 d sess. Rep. Com. No. 108. Washingtor, DC: GPO, 1863.

U.S. Congress. Senate commitee on midtary Artairs.

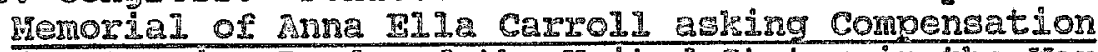
POr Service Rencered the United states in the War of the Rebelinon. 2 a cong. 2 d sess. Sen. Mis. DOC. 167. Washington, DC: GPO, 1872. 
U.s. Congress. Senate. Committee on Military Affairs. Memorial of Anna Ella Carroll of Maryland, Praying for Compensation for Services Rendered to the United states during the late Civil war. 45 th cong., Ist sess. S. Mis. DOC. 5. Washington, DC: GPO, 1877.

U.S. Congress. Senate. Committee on Military Affairs. Fetition of anna El la Carroll, praying Compensation for Suggesting Certain plans of operation for the Armies of the Unjted states During the Late War. 4Ist Cong., 2d sess. 5. Mis. Doc. 100. Washington, DC: GFO, 1870 .

U.S. Congress. Senate. Committee on Military Affairs. Report. 45th Cong. 3d sess. So Rept. 775. Washington, DC: GPO, 1879 .

U.S. Congress. Senate. Committee on Hiltary Affairs and the Miditia. Report to Accompany 3.1293. 4.st Cong., 3d sess. So Rept. 339. Washington, DC: GPO, 187I.

3. Newspapers and Periodicals

LOuisvi11e [Tentre]ry] JournaI

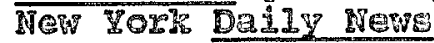

Mew York Espress

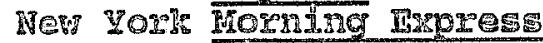

NeW YOR Times

Waspington National Republican

Whasington Daily National Inte11. Igencer

Woman $\mathrm{g}$ Touzmel

4. Reference Worrs

Americar Directories Phyough 1860. Mer Haven, Comnectucut: Research Publishers, 1969. MLicofiche.

Apo Leton's Cyclopedia of American Blograpin. 6 vols. Fdited by James Grant wilgon and Jonn Fisle. New Yors: D. Appleton \& Company, 1886-1891.

A Blograplical Dictionary of the Maryland Iegislature. 2 vols. Rasted by Raward C. Papenfuse. Alan I. Day. David w. Joran, and Gregory Ro Stiverson. Baltimore: Fohrs Fophins University Pres, 1979-1985.

A Bographical Qirectory or the American Congress. 
1774-1971. Washington, DC: GPO, 1971.

Biographical Dixectory of the Governors of the United States, 1798-1978. 4 vols. Edited by Robert Sobel and John Raimo. Westport, Connecticut: Meckler Books, 1978.

Boatner, Mark M. III. Civil War DLctionary. New York: Davia Makay Co., 1959.

Congressional Quarter1Y. Guide to 0.5. Rlections. Washington, DC: Congressional Quarterly, Inc., 1975.

Dictionary of American Biography. 12 vols. Edited by Allen Johnson. New York: Charles Scribner's Sons, $1964=1973$.

1800 Census Index. Eds. Ronald $\mathrm{V}$. Jackson, et al. Bountiful, Utah: Accelerated Indexing systems, Inc., I976。

The zandbook of Texas. 2 vols. Edited by Walter Prescott Webb. Austin, Texas: Texas State Historical Association, 1952 .

Hartis, Renneth c. The Historical Atras of United States Congressional Districts, 1789-1983. New Torts: Free Press, 1982.

National Gyelopedia of American Blography. 62 vols.

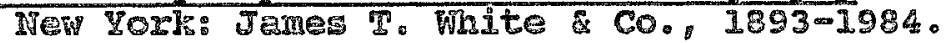

National Register of Historic Places. Washington, DC: U.S. Department of Interjor, 1976.

Notable American momen, $160 \%$ - 1950. 3 volw. IEdted by Echara T. James. Cambroge, Massachusetts: Rarvard Univeresity Press, 1971.

imerican women. 2 vols. Edited by Frances E. Willard Mary A. IIvermore. New Yor\}: Mast, Crome1.1 \& Kirlepatrick, 1897: reprint ed., Detroit: Gale Research Co., 1973.

\section{MOrgse by Carrol}

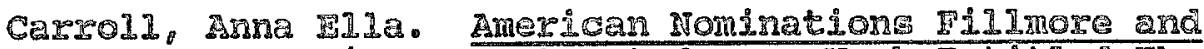
Donelson: Belng an Frteract from a rorg Entritled rae Great American Dattle: or The Conisest between 
Christianity and Political Romanism. New York: Miller, Orton \& Mulligan, 1856.

-..-... "Calhoun and His Nullification Doctrine." Living Age 70 (17 August 1861):444-446.

- The constitutional Power of the President to Make Arrests and Suspend the Writ of Habeas Corpus Examined. Maryland: n.p., 1861.

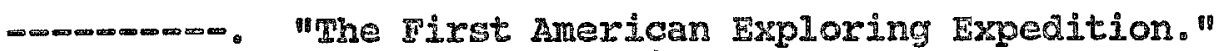
Harper's Hew Monthly Magazine 4A (December 1871): $60-64$.

-m-n-m. The Great American Battle: Or, the Contest Between Christianity and Political Romanism. drew Yorr: Miller, Ortor \& Mulligan, 1856.

man-mman. Miss Carroll's Claim Before Congress Asping compensation for Military and other services in connection with the Civil way. [Washington, DC, 1874 ]

-mman-m. Miss Carrol1's Claim Before Congress in connection with the Tennessee campaign. Washington. DC: n. . . 1873.

Country During the Civil War stated. [Wrshington, $\mathbb{D C}_{8}$ C. 2874$]$

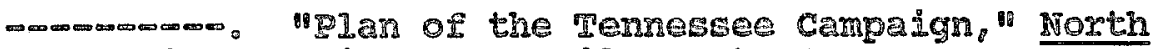
American Revien 42 (Apr: 1386 ):342-347.

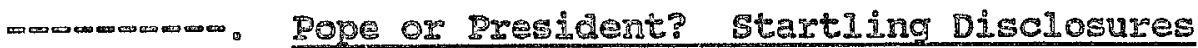
QI Roman

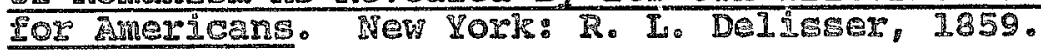

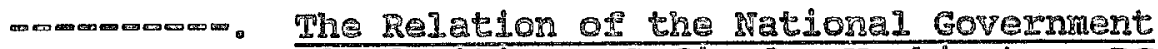
to the Revolted Citiens Defined. Washington, DC: Wenry Rolsinhorn, [1862].

- manmman. Reply to the Speech of Hon. J. Co Brechinridge, Delivered in the UnLted States Senate, July 14, 186I and, In Derence of the Dresident' $\mathrm{g}$ War Measures. Waskington, DC: Henry Polkinhorn, 1861.

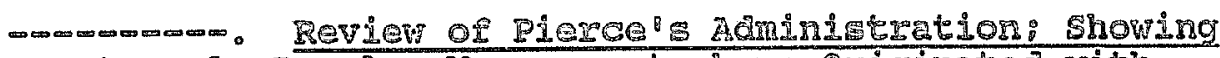
Tts onIy popular measuzes to have Originated with the parecutive of phIIard Fillnore. Boston: James 
French and company, 1856.

-n-.-. The Star of the West; or, National Men and National Measures. 3d ed. Boston: James French and Company, 1857.

-

- The Union of the States. Boston: James

French and Company, 1856.

- War Powers of the General Government.

Washington, DC: Fenry Polkinhorn, 1861.

-m-mich? Plilmore or Buchanan! Boston:

James French and Company, 1856.

- Who Shall Be President? An Appeal to the

Peop 2e. Boston: James French and Company. 1856.

\section{Works on Carroll}

Articles

Armstrong, Walter P. MTe story of Anna Ella Carro11: Politician, Lawyer and Secret Agent." American Bar Association Journal 35 (March 1949): $198-200$.

Blackwel1, S. E1len. "The Anna Fla Carroll Fund." Woman's Column 5 (28 January 1888): n.p.

BHakwe11.5. E. "The Case of Miss Carrol1." Century Magazine 40 (August 1890):638-639.

Brad1ey, Sylviณ. "Anna Ela Carro11, $1815-1894:$ Miditary strategist-political Propaganaist. In Watable harylana Women. Ed. Minifred G. Helms. Cambridge, Maryland: Tidewater Publishers, 1977. pp. $62=70$.

Buldare, F. Lauriston. "Arna FIla Carroll and Her "Hodest claim. Iincoln Herald 50 (October $1948): 2-10$.

Chandiez, Lucinda B. "Anna FIla Carrol1: The Great Unrecognized centus of the war of the Rebelilon." Godey S Marazine 133 (September 1896):250-267.

Copinger, mey Irene, "yaryland women Influenced U. S. Destiny. Gr Baltimore Sun, II Oetober 
1925.

Gould, Kenneth M. "Lincoln's Unknown Soldier." Senior Scholastic 68 (9 February 1956): 16.

"Iincoln's Lady Strategist." Iife, $26 \mathrm{July} \mathrm{1948,}$ pp. 101-102.

Long, E. B. "Anna IIla Carro11: Exaggerated Heroine?" Civil War Times Illustrated 14 (July $1975: 28-35$.

"My Dear Iad" " Moman's Home Companion 67 (February 1940): 13-14: 67 (March 1940):26.

Weal. H. W. "Secret Heroine of the Civil War." Coronet 26 (May 1949):148-152.

Shattucls, H. R. "Anna IIII Carrol1: The Originator or the Tenressee Cempaign." Outing 6 IJuIY $1885): \triangle 03-409$.

Shutes, Dr. MiIton H. "Heet an Unheralded Heroine." National Republic ragazine 22 (Novenber 1934): 3004.

Snyder, Charles McCool. MAna Ella Carrol, Political strategist and Gadfly to president Filmore." Maryland Hiscorical Hagazine 68 (spring 1973): $36-63$.

Farbe11, Ida M. "The American Woman: How She Ret the Esperience of Wra." American Magarine 69 Apg1 1910):801-814.

Fi111aws, Kenneth $D$. "rohe Tennessee Campaign and Anna Ansa Ella Carroli." Indiana ragagine of History 46 (september 1950 ) : $221=248$.

Boogs

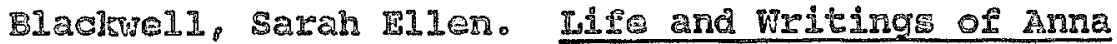

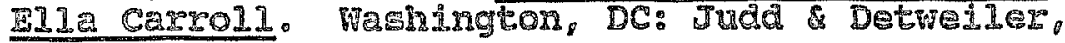
1895.

$-\infty-\infty-\infty-\infty \circ$ I Cerpol1 of Maryland. Washingtor, DC: Judd \& Detwe119R, 1891. 
Greenbie, Marjorie. My Dear Lady: The story of Anna Ella Carroll, the "Great Unrecognized Member of Iincoln's Cabinet". New York: McGraw Hill, 1940.

Greenbie, Sydney. Suit with Red Lining. Penobscot, Maine: Traversity Press, 1958.

Greenbie, sydney and Marjorie Barstow. Anna Flla Carroll and Abraham Iincoln: A Biography. Manchester, Maine: University of Tampa Press in cooperation with Falmouth publishing House, Inc., 1952.

Noble, Hollister. Woman with a Sword. Hew York: Doubleday, 1948 .

Wise, Winifred $\mathrm{t}$. Iincoin's Secret Weapon. New Pork: Chilton CO., 1961.

Pamphiets

Courins, Phoebe W. The Military Genius of the War. Anna Flla Carroll, Author of the Tennessee Campaign. St. Lou's: N.P., 1882 .

[Evans, Ienuel D.] The Matexial Bearing of the Tennessee Campajan in 1862 upon the Destinies of Our Civil War. Washington, DC: W. H. HoOre, [1871?].

Gage, Matilda JosIyn. Who Plamed the Tennessee Campalgr of 1862: Or Ama EII Ca Caroll VS. U. S. Grant: A Few Cenerally Unirrown Facts in Regard to our Civil War. Nat donal Citizen pract No. I. Washingtong $D$ : 1880 J

Fussey, C. C. Mids anna Ella Carrol1, as Author of the Tenressee Campaign in the Late civil War. Rast orange, New Jersey: Gazette steam Book \& Job Radne 1885.

Noble, Follister. "The Facts about Anne Carroll and the story behind Woman with a Sword. "New York: DOubI. Aay \& CO. 1948.

5cott: Gegt. Charles IR. The OrIgin of the Tennessee Campajan by capt. Charies H. Scott, as a RefutaEion of the Fradulent [sje] Clahn of Miss Anna

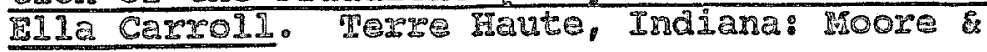


Langen, 1889.

White, Hon. John D. Speech in House of Representatives, February 7,1884 . Washington, DC: n.p., 1884 .

Lawsuits

Anna Ella Carroll v. United States. 20 court of clains 426 (Court of claims 1885).

Marjorie Barstow Greenbie v. Hollister Noble, Doubleday and Company, Inc. Sears, Roebuck and Company, Rational Broadcasting Company. Inc., Batten, Barton, Duxstine \& osborne, Inc., E. I. Dupont Memours \& Co., (Inc.), Foote, cone \& BeldIng, Ine, and Fallmarje Cards. United states Distriet Court, Southern District of New York, Civil 94-300. Bayonne, Nev Jersey: National Archives, New York Branch.

\section{Book Reviews}

Alen, Herbert. "New Iight on Linco In's 'Serret" war Tactieian "Revo of woman with a swora, by Hollister Noble. Boston Herald, 2 February 1949 .

Bardolph, Richard. "Mrna FIla Carroll and Lbraham Iincolno Revo of Ann FII Carroll and Abraham Iincoln: A Biography, by Sydney and Marjorie Barstow Greenoi. Journel of Southern History 18 (November 1952):511-513.

Bond, Alice Dison. "Biography Discloses woman Whose Strategy Saved Union." Rev. of homan with a Sword. Boston Sunday Herald, 24 October 1948.

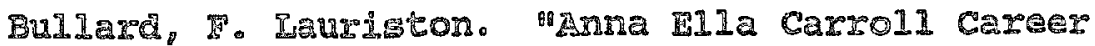
Persuasively, Ploguent I Told." Rev. of Myy Dear Lady, by Marjorie Barstow Grenisie. Boston Hera 1d, 9 october 1940.

Craven, Avery. MReview ${ }^{\circ}$ Rev. of Anna Rla Carroll and Abrahan Lincoln, by Syaney and parjorie Barstow Grenbie. New YOrh Herald Mribune Book Revien, 26 october 1952. 

Greenbie, Sydney. "Reply to Kenneth Williams." Rev. of "Anna Ella Carroll and Abraham Iincoln" review by Renneth Williams. Iincoln Herald 55 (Spring 1953) : 37-41.

Stowe, Iyman Beecher. "In IJincoln's Kitchen Cabinet." Rev. of My Dear Iady, by Marjorie Barstow Greenbie. New Yor] Times Book Review, 8 December 1940.

Thompson, Ralph. "Books of the Times." ReV. of My Dear Lady, by Maxjorie Barstow Greenbie. New York Times, December 1940.

Wi11 DIIa Carroll and Abraham Iincoln." ReV of Anna ElIe Carroll and Abranam Iincoln: Biography by Sydney and Marjorie Barstow Greenbie. Iincoln Herald 54 (Summer 1952): 54-57.

\section{Media Productions:}

"Anma Flla Carrol1." Wroit. Robert Tallman. Cavalo cade of Anerica. $\mathrm{NBC}$ Radio, 2 June 194I.

Grenbie, Sydney ar Was a Iady. T.S. Theatre Collections. Nery Yorg Public Libraxy, New York, New York.

Strange Glox. Dix. Jacgues Tourneur. Metro-GoldWy-Mayar, 1938 .

"Woman with a Sword. Writ. Hollister NobIe. Cavalade of Americe. Adagt. VIrginda Radeliffe. IVBG Radio, 23 MaY 1949.

"Woman with a Sword." writ. Hollister Noble. Hallo mare Hall of Fame. Dir. Willigra Corrigas. NBC Television, I0 Tebruary 1952.

"Woman with a Sword." Writ. Hollister Noble. Play house 25 Broadcast. Armed Forces Rmdio \& TV Services, n.ä.: Rebroadcast, 42d Meelk, 1974.

7. Primary Sources

Adam, Henry ahe Great Secession Finter 04 1350-61 
and Other Essays. Ed. George Hochfield. New York: Sagamore Press, 1958.

African Repository, and Colonial Journal. 68 vols. n.p.: Kraus Reprint Corporation, 1967.

[Anspach, Frederich]. The sons of the sires. Philadelphia: Lippincott, Grambo \& Co., 1885.

Anti-Catholiaism in America, 1841-1851: Three Sermone n.p, n.d.: reprint ea., Hew York: Armo Pres, 1977.

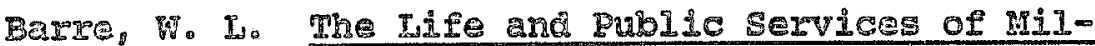
Iard Fillmore. N.p.: $\mathrm{n.p} \cdot \mathrm{g}$ 1856: reprint ed.

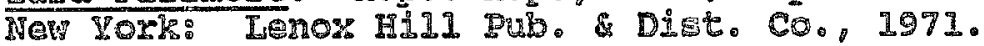

Bamler, Roy $D_{0}$, ed. The Collected Forjs of Abraham Lincoln. 9 volv. New Brunswids, New Sorsey, $1953=1955$.

Beale, Howard $K_{\text {, }}$ ed. Diary of Gideon Welles: Secretany of the Mavy Under IIncoln and John son. Nev Yos?: W. W. Norton, 2960.

Birmey, Horace. "Mhe PrIvidege or the writ of Habeas Corpus under the Constatution. In Union Pamphlets of the civil var. ge. Frans Fre1de1. 2 volg. Canoridge, Masmachusetts: The BeImap Press of Harvard Undvergity Pues: $196 \%$

Botts, Jom Minor. Lue Great Rebeln Ion: Its secret Hidtory, Rise, progress, and DLSastrour Faiduge. Jew Yorm: Harper \& Brothers, 1866.

Carhoun Iohn c. m Discourse on the constitution and the Govermment of the United states. ${ }^{\text {m }}$ In The

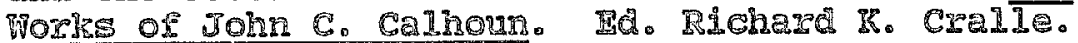

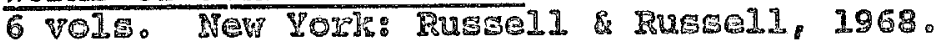

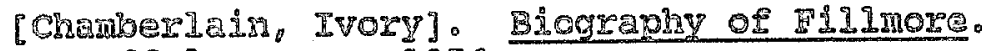
Buffa10: $8 . \%$, 1856.

Chittendan, I. I. A Report of the Debates and Pro ceedings in the Secret Sescisons of the conference Convention for proposino Amendrents to the Constituiton of the United States. Hald at Washo ington, D.G. in Felaruarg, A.D. 186I. NEW Yor?: D.APIETON CO. 186a. 
Grant, Ulysses s. The Papers of Ulysses $\mathbf{s}$. Grant. Ed. John Y. Simon. 14 vols. Carbondale, IIIInois: Southern Illinois Press, 1967-1985.

Grant, Ulysses $S$. Personal Memoirs of U. .S. Grant. 2 vols. New York: Charles L. Webster \& Co., 1885 .

Greeley, Horace and John F. Cleveland. A Political Testbook for 1860: Comprising a Bries View of Presidential Nominatons and alections: InciudIng 211 the Pational Platforms Fver Yet Aciopted: Also A History of tre struggle respecting SIavery in the Territories, and of the Action of congress As to the Freedom of the Public Lands, with the post rotahle speeches and Letters of Messmo Lin coln, Douglas, Boll, Cass, Seward, Jverett, Breclsinridge. H. V. Johnson, etc. ete. Pouching the Questions of the Day: and Returns of all Presiden

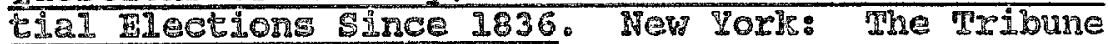
Astociation, 1860.

Ha Istead, Hurat, Caucuses of 1860. Columbus, Onjo: Follet, Foster CO., 1860.

resseltine, wiIIan B. and Rey Go Fisherg, eds. Trimmers, Trualers and Tempordzers: Notes of Murat Halstead from the Political conventions of 1.856. Madigong 7isGongin: The state mistorical Society of wisconsin, 1961.

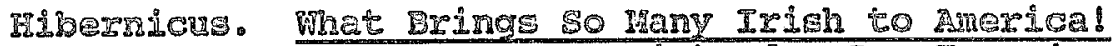

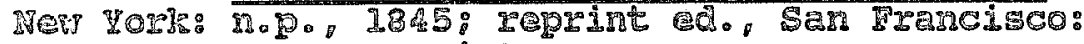
R \& R Research Associates, 1972.

Marsh, Fphreim. Nortin Anerican Documents. Letters Hrom Geore Iaw, Ephraim Marsh and Chauncey

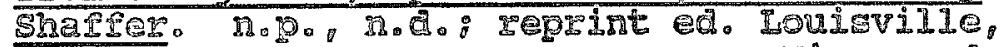
Ifrtucky: Lost Gave Rress, 1962. Microcara.

Moore, Frans, ad. The Rebellion Record: A Diary of Mnerican Events, with Documentis, Nazagtives, IlIustrative Incidents. Poetrye etc. II vols. Jew Yors: G. P. Putnan \& Char 1es T. Trans, 28611863: Wew Yor?: D. Van NOStrase, 1864-1868.

Jozse, Samuel F. B. Imuinent Dascers to the Tree Instiburions of the Unjted states through Foreion

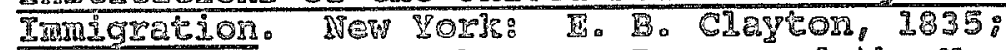

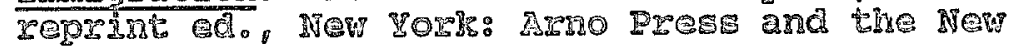


York Times, 1969.

Official Records of the Union and Confederate Navies in the War of the Rebellion. 27 vols. Washington, DC: GPO, 1894-1917.

Dopulation schedules of the Third census of the United states, 1810 . Washington, DC: Wational Archives and Records Service, 1959. Microfilm.

Population schedules of the Fourth census of the United states, 1820. Washington, DC: National. Archives and Records Service, 1959. Microfilm.

Proceedings of the Fingt mree Republicar National conventions. Inimeapolis: Charles W. Johnson, 1893.

Ridhardson, James D. ed. A Compilation of the ressages and Paperes of the Pres iaents, 1798-1902. 10 Vol. Washington, DC: Bareau of Nationel Iiterature and Art, 1905.

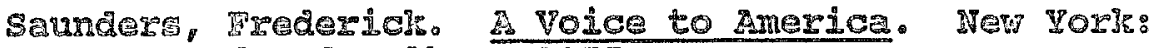
York: Tdward Waliser, 1855.

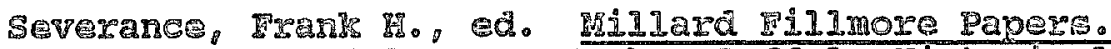
2 vols. Buffalo, Mew york: BuffeIo IIStordcel Societr: 1907.

The war of the Rebellion: Is Complation of the oficicial Records of the undon and Confederate Armies, 70 VOLs, Washington, DG: GPO, 1880m 1902 .

Whitney, Thomas $B_{0}$ D Detense or the Amezicass Policy, Hew Yorm: Dewitt \& Davenport, 1856: Eeprint ed., n.9.: Jerome S. Ozer, 1971.

meed, "rhus Iov, Iffe of Mhurlow weed. ed. Harriet

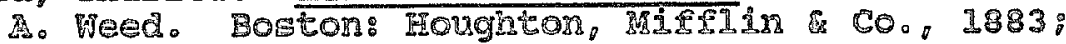
Ieprint ed. JVer York: Da Capo REess, 1970.

WaIsez, General willian。 The War in NICaragua.

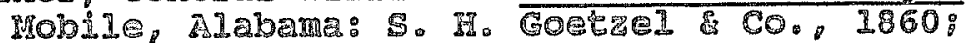
reprint ed., Detroit: Blaine rinxidge-Bools, 1971.

8. Secondagy Sources 


\section{Articles}

Brewer, James H. Fitzgerald. "The Democratization of Maryland, 1800-1837." In The 01d Line State: A History of Maryland. Ed. Morris I. Racoff. Annapolis: Hall of Records Commission, 1971.

Brewer, W. W. "Iincoin and the Border States." Journal of Negre History 34 (January 1949): $46-72$.

Brown, Richara D. MSodenization: A Victorian Cimax. "In Viatorian America. Ea. Daniel walkar Howe. Philadelphia: Jniversity of Pennsylvania Press, 1976. pp. 29-44.

Carman, Hary J. and Ifichard I. Iuthin. "Some Aspects of the know-Nothing Hovement Reconslaered. South Atlantic Quarteriy 39 $(1940): 213-234$.

Claxp, Chex"les B. "Suppression and control of Maryland, 1861-1865; A study of Federal-state Relations During Civil Coniliet. Maryland Ristorical Magazine 54 (September 1959):24I271.

Crenshaw, ollinger "The speakerghip contest of 1859-1860。 Beviev 29 (December 1942):323-338.

Gorts, Danied Giner and Iincoln Gabinet. Civil War HAdstory 24 (Septenber 1978):225-249.

Davi๋, Davia Brion. "Some Ideologicel Functions of of Prejualce In Ante-Bellun America." Anexican Quarterly 60 (Summer 1963): 115-125.

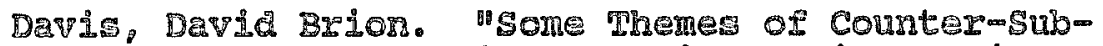
version: An Analysis of Anti wasonic, Areim Catholic, and Anti-Romon IIterature. ${ }^{8}$ MissisSLPol VaIIey HIStorLCaI Review 47 (5eptember $19601: 205-224$.

Duscan, Bichard R. "The Era of the Civil war" In IPaxy 1and: A History, 1632 to 1974 Ed. RIChard Walsh and William Iloyd Fos: Baltimore: 
Maryland Fistorical Society, 1974.

Fehrenbacher, Don $\mathrm{E}$. "The Origins and Purpose of Iincoln's 'House-Divided' Speech." Mississippi Valley Historical Review 46 (March 1960):615-643.

Frasure, Carl M. "Union sentiment in Maryland, 1859-1861." Maryland Historical Magazine $2 \%$ (September 1929):210-224.

Camett, James Mercer. "John Francis Mercer, Governor of Maryland, 1801-1803." Haryland Historical Magazine 2 (September 1907):191-213.

GIenapp, Wilian I. Mativism and the creation of a Republican Majority in the rorth Before the the Civil War" "Joumal of American History 72 (December 1985):529-559.

Hales, Jean coula. "Co-laborers In the Gause: Fomen in the Ante-bel Iurn Nativist Movenent." Civil War History 25 (June 1979):119-135.

Faller, Mark Darey in mary dand, 1820-1329." Jourral of Southern History28 (August 1962$): 307-326$.

PHicks, John D. "ghe Thixd Party Traditgos ir

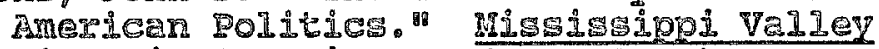
Historicai Revien 20 (June 1933):3-23.

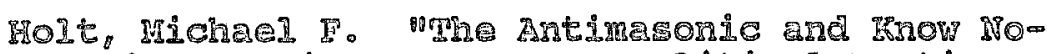
thing Parties In O.S. Political Parties. IA. Arthur Yors: Cheleea House Publishor: in assoctation

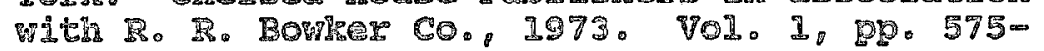
740 .

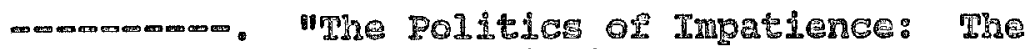
OrIgins of Inow Nothing can Hastory 60 (Segtember 1973$): 309-331$.

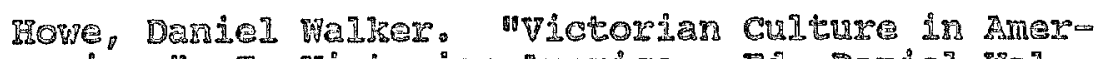
lce." In victorian Americe. Ed. Dandel waI-

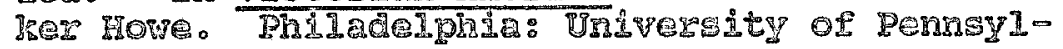
varie Press. 2976 , p9. $3=28$.

Jackson, Donald DaIe. "Around the world with

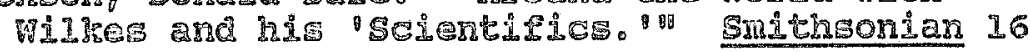


(November 1985):48-63.

Janes, Henry I. "The Black Warrior Affair." American Historical Review 12 (January 1907): $280-298$.

Johnson, Ludwe11 $\mathrm{F}$. "Contraband Trade During the Itast Year of the Civil War." Mississipoi VaIIey Fistorical Review 49 (Mareh 1963):635-652.

$-\infty m-\infty-\infty-\infty$. "Whe Confederagy: That Was It?

A View Irom Ele Federed Courts." Civil War

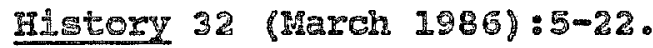

monnm-nom. Myortherr Profits and Profiteers: The Cotton Hisage of $1364-1865$. CIVi1 War History12 (June 1966):101-115.

Sones, anne Goodnyn. "Southers Iitenary Women As

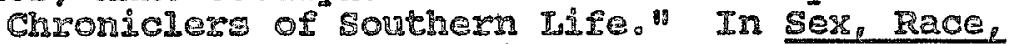
and the Role of Women in the South. Ed. Joanne $V$. Hawrs and Shejla Lo Stremp. Jackson,

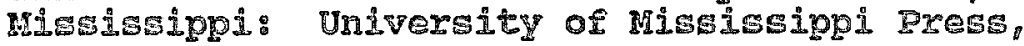
1983.

Re11y, Jo Reaney. "Cedar Park, Its People and Its Iistory 58 March 963$) \longdiv { 3 0 - 5 3 }$.

Mad:ㄱish, Stephen I and tre Crjsis of the Union: The Inownothing

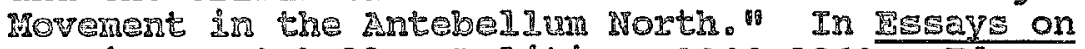

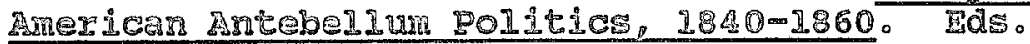
Stephen R. Majulish and John J. Rushma college Station, Fexas: Unjversity of Texas at Arling ton by Tespas An University Press, 1982. 190. $166-198$.

Sinth, Donnal T. "The Influence of the Foreign Bors of the Northwest in the Election of 2860."

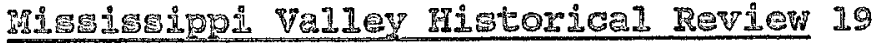
(5eptemiar 1932$): 192-204$.

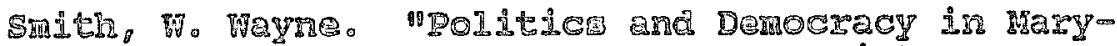

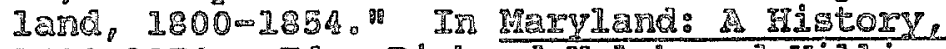

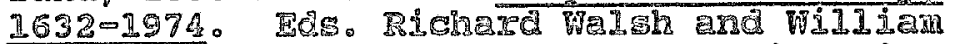

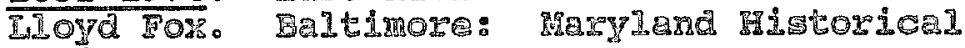
Sochety; $197 \%$.

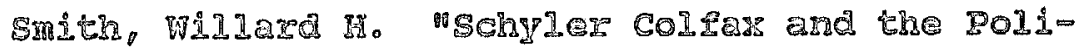


tical Upheaval of 1854-1855." Mississippi Valley Historical Review 28 (Deceriber 1941):383-398.

Smith-Rosenberg, Carroll and Charles Rosenberg. "The Female Animal: Medical and Biological Views of Woman and Hex Role in Hineteenth-century America." Journal of American History 60 (September 1973):332-356.

Stephenson, George Mo "Wativism in the Forties and Fifties, with special Reference to the Mississippi Valley." Mississippi Valley Histor ¿Cal Review 9 (December 1922):185-202.

Tuska, Benjamin, "Inow-Nothingisn in Baltimore, 1854-1860. Cathol IC Historical Review 5 (JuIy 1925):217-25I.

Van Hess, James . "Mgonomic Development, Soclal and Culturel Changes: 1800-1850." In Maryland: A 17ibtory, 1632-1974. Fas. Richard WaIsh ene Wiliam IIoyd Fo\%. Baltimore: Maryland Historical Society, 1974 .

PeVier, Charles, "American Continentalism: An Idea of Expansion, 1845-1910," American Histor ica1 Review 65 (January 1960):323-335.

webster, chyde C. Monn Minor Botts, Antimsecesriorist." Richmond College Historical Papers 1 (Jนทอ 1915):9-37.

Helter, Barbara. "The cult of True womanood." Amezican Quarterlyz 18 (1966): 151-174。

Wi1son, Charles R. "The Ordglnal chase Organima

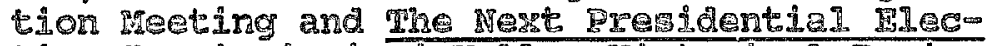
tion." Missission I Valley HIStorical Revier \&3 (Tu⿰ 1236):61-79.

DOORE

Anderson, Bern. By Sea and By RIVEr: The Naval Pastorr of the Civil Wer. NeW Yorlt: 2lfred A. Rnopf, 1962: reprint ed., wastoport, connecticut: Greenwood Press, 1977.

galsex, Jear H. Mmbivalent Amezicans: Whe Rnow- 
Nothing Party in Maryland. Baltimore: Johns Hopkins University Press, 1977.

-n-me politics of Continuity: Maryland Political Prties from 1858 to 1870 . Baltimore: John: Fopkins University Press, 1973.

Bea1:, Carleton. Brass-Krucle Crusade: The Great Imow-Nothing Conspiracy, 1820-1860. New York: Hastinga House Publichers, 1960.

Bidington, Ray Alen. The Origins of Nativism in the United States, $1800-1844$. Dissertation, Fervard oniversity, 1933. New Yor]: Arno Press, 1974.

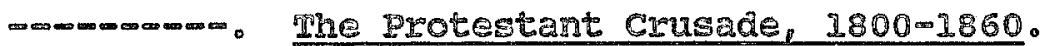
New York: Sinehart \& Co., 1938; reissue ed., 1952.

Birmingham, Stephen. The Grande Dames. Hew Yorj: SImon \& Schuster, 1982.

Blue, Frederiak I. The Fee-soilers whird Party Politios, 1848-1854, Urbana, I111nois: University of IIInois Press. 1973.

Burnham, Dean, Presidential Ballots, 18361892. Baltimore: Johns moplins University 19ess, 1955.

Can, Marvin Ro Incoln's Atorney General: Bawara Bates of missourí Colvmbie, Rissouri:

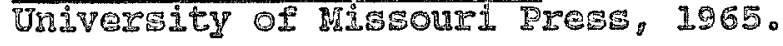

Campiond. Penelope. Maryland in Arrica: The Mary 2 and state colonization Society $1832-1857$.

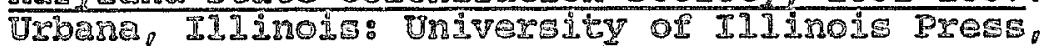
1972

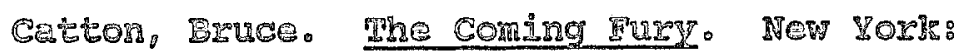
Doubleday。 196:。

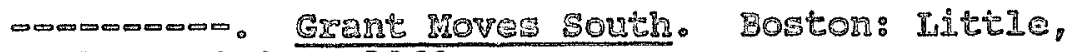
Brom \& $\mathrm{CO}$. 1960 .

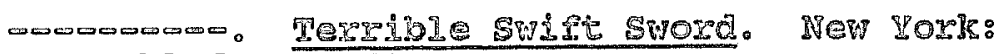
Dovis 1042y, 1963.

Givil Wax Neval Chronology, 1865-1865. Compined 
by U. S. Naval Department, Naval History

Division. Washington: GPO, 1971.

Clegern, Wayne M. British Honduras: Colonial Dead End, 1859-1900. Eaton Rouge, Louisiana: Louisiana state University Press, 1967.

Clinton, Catherine. The Plantation Mistress: Woman's World in the ola South. hew York: Dantheon Books, 1982 .

A Comprehensive History of Texas, 1685-1897. Fd. Dudley $G$. Wooten. Dallas: William $G$. Scarff, 1898.

Cox, Ir Wancla Inincoln and BLach Freedom: A stuay in Prestdential Ieadership. Columbia, South Carolina: Injversity of South carolina Eress, 198 .

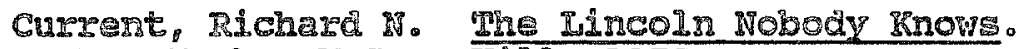
New Yorg: HeGraß- Hid, 2958.

Cuthbert, Norma. Inincoln and the Baltimore PIot. San marino, Califoria: Huntington library. 1949.

Davenport, T. H. The History of the supreme conrt or the state of Tessas. Austing Texes: 5Outhern Law Bools Publishers; 1917.

Davi๋, Devid Brion, ed, The Fear of Conspiracy: Images of Un-AMerican Subversion From the ReVOIngion to the present. Ithaca Hew Yoz"J: Correly Undversity Press, 2971.

Dubin, Thomas. Women at Work: Whe pransforma bion of Worl and Community in Lowell, Massa" chusett, 1826-1860. Nev Yorts: Columbia UniVergity Press, 1979.

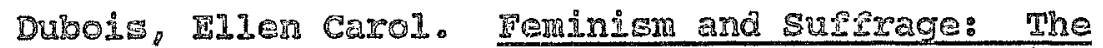
meronee of an Independent Women 's Movement In Americe, $1848-2869$. Ithaca, New York: Cornell University Press, 2978.

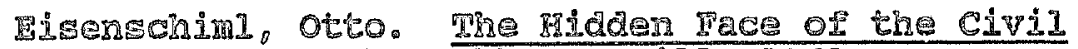
War. NeW Yor?: Bebbs-Imerzil1, 2961 .

Thtinger, Mmos Aschbach. The misgion to Spain of 
Pierre Soule, 1853-1855. New Haven, Connecticut: Yale University Press, 1932.

Evitts, William J. A Matter of Allegiances: Maryland From 1850 to 1861 . Baltimore: Johns Hopkins University Press, 1974.

Pe11. Sister Marie Leonore. The Foundations of Nativism in American Textbooks, 1783-1860. Washington, DC: The Catholic University of Anerica Press, 1941 .

Fite, Emerson David. The Presidential Campaion of 1860. New York: Macmillan CO., 1911.

Flesner, Fleanor. Century of struggle: The women's Rights Movement in the United States. New York: Atheneum, 1973.

Foner, Fric. Free Soli, Free Labor, Free Mer: The Ideology of the Republican Party Befose the civil War. New York: Oxpord University Press, 1970.

Frankin, John Hope. From SIaverg to Freedom: A ristory of regro americens. 3a gition. New York: Vintage Bools, 1969.

Freided, Framp ed. Urion PamphIets of the civil War, 1861-1.655.2 Vols. Cambrage, Massachu

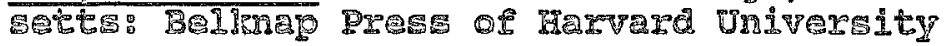
Pres: 1967 .

Friedrsid, Otto. Clover. New Lork: Simon and SChuster, 1972 .

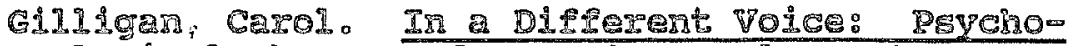
logical Theory and Women's Development.

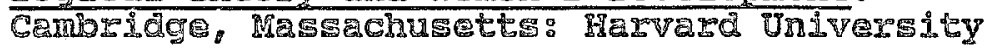
Press: 1982 .

Gosne11, F. A12n. Gurs on Western Waters. Baton Rouge, Louigiana: Louisiana State University Pres:, 1989.

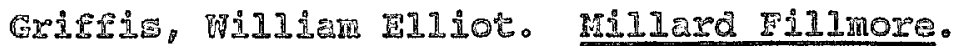
Ithece, Hew IOrle: Andrus \& Chureh, 1915.

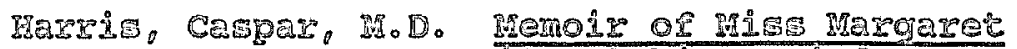
mercer. ad ed. PhILadohia: IIndeay 
\& Blakiston, 1848 .

Hendrick, Burton J. Iincoln's War Cabinet. Boston: Iittle, Brown \& Co., 1946.

Higham, John. Send These To Me. New York: Atheneum, 1975.

- Strangers in the Iand. New Yorts: Atheneun, 1971.

Hof:sadter, Richard, The Paranoid Style In Anerican Pol ties and other Essays. HeV For\%: Dlfred A. Kropf, 1966.

Rolts manael F. Forging a Majority: the Fonmation of the Republican Party in Pittsburan 1848-1860. MeV Haven, Comecticut: YaLe UทIVer.

mammman. The Political Crisis of trie 18509. New TORE: John Wiley \& Sons 1978.

Howe, Dandel HaIker. The Political Culture of the American migre chisago: Unjversity of Chicago Prese, 1979.

Janมings, Thelme. The Hashvile Convention: Southern Movenene for Unjtz: $1848-1851$. Mempin Tennesses: Memphis state Undversity Press: 1980 .

Jensen, Gary Demis. Joseph Sabin and His MDiCo tonary or Books Relating to Amenica" Ams

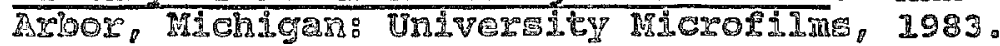

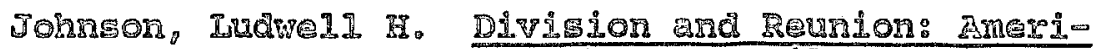

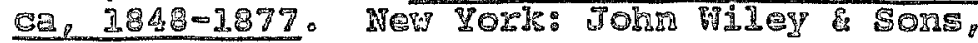
2978.

Jones, Elias. Revised IIItory of Dorchester County, Mary Iand. Baltimore: Read Taylor Exess, 1925 .

Jones, Firgid carrington. The Civil war at Sea.

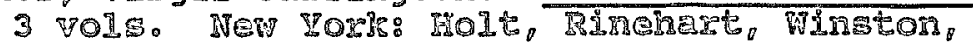
1960.

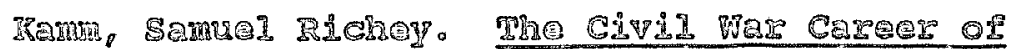

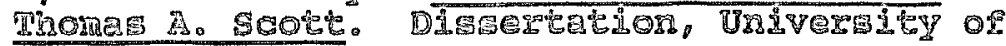


Pennsylvania, 1940. Philadelphia: University of Pennsylvania Press, 1940.

Karnes, Thomas I. The Failure of Union: Central America, 1824-1975. Tempe, Arizona: Arizona state University Press, 1976.

Kexber, Iinda $T_{\text {. W }}$ Women of the Republic: Intellect and Ideology in Revolutionary America. Chapel Hill, North Carolina: Institute for Early american Higtory and culture by university of North Carolina Bress, 1980.

Traditor, Aileen 5. The Ideas of the woman Suffrgege Hovement, $1890-1920$. Hew York: Anchor Books, 1981.

Lexner, Gerda. The crimlé sisters from South Caroline: Pioneers for Woman's Rights and Abolition. New Yorls: Schocken Books, 1967.

$-\infty-\infty-\infty-\infty$. The Hajority Finds Its Past: Placing Woner in History. New York: Oxford University Press, 1979.

Liverwore, Wary A. MY story of the War: A Wom man $^{\circ}$ : Rarrative of Four Years Personal Exper ience as Nurse in the Union prmy and in Relief Worls at Home, in Hospitals, Camps, and at the Front, During the War af the Rebelilon. rarteford, Connecticut: A. D. Worthington, 1889.

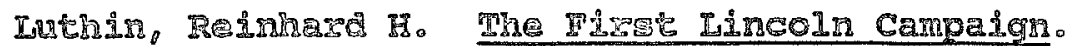
CIoncester, Jussachusts: Petar Smith, $2964:$ reprint ed., Canbridge, Hassachusetts: Harvard

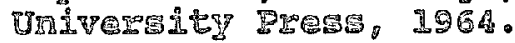

Iyser. James D. The Bench and Bar of rexas. St. Loul: Nixon-Jones Printing Co., 1835.

ILhan, Alfred T. The Gulf and Inland waters. Nev York: CharIes Scribner's Sons, 2883.

Hanalze, Harold R. Maryland in the Civit way. Baltimore: Maryland Hi.

Ray, mobert r. The Southern Drean or a Caribbean IMpire, I854-1861. Baton Rouge, Loulsiana: Iovisiane State Universisy Press, 1973. 
Miers, Earl schenck, ed. Lincoln Day By Day, A Chronology, 1809-1865. 3 vols. Washington, DC: Lincoln Sesquecentennial Commission, 1960.

Mckee, Thomas Hudson. The National Conventions and Platforms of All Political Parties, 1789 1905. Baltimore: The Friedenwald Company, 1096 .

McPherson, James M. Ordeal By Fire: The Civil War and Reconstruction. New York: Alfred Knopf, 1982.

Neely, Mart E., Jr. The Iincoln Encyclopedia. New York: McGraw-Hi11, 1982 .

Nevins, Allan. The Emergence of Iincoln: Prom logue to civi 1 War, $1859-1861$. New York: Charles Scribner'g sons, 1950.

$-\infty m-m \infty$ Oraleal of the Union: A House DividIng, 1852-1857. New York: Charles Scribner's Sons, 1947.

w-m-m-m. The Wax for the Union: The Organized war to Vietory, 1864-1865. New Yorle: Charles Seribnex's Sons, 1971.

-m-m-m. The War for the Union: War Becones Revolutdor, 1862-1863. New Fork: Char1es Seribrest's Sons, 1960 .

NiGhols, Roy Franklin. Franielin Plexe: Young Hijory of the Cranite FinIIs. Philadelphia: University of Penasy lvanie Press, 1969.

Norton, Mary Beth. Iiberty's Daughters: The Revolutionary Experience of American women. 1750-1800. Boston: Iittle, Brom \& Co., 1980.

Overdyke, W. Darre11. The Inow-Nothing Party in the South. Baton Rouge, Louisiana: Louisiana state unjversity Press, 1950.

Paulin, Charles Oscar。 Paullin's History of Maval Administration, 2755-1911. Innapolis, Maryland U. S. Naval Institute. 1968.

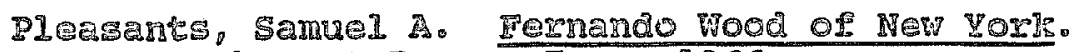
New York: Rus Press, InC. 1966. 
Potter, David $\mathrm{M}$. The Impending crisis. Ed. Don E. Fehrenbacher. New York: Harper \& Row, 1976.

-n.m. Incoln and His Party in the secession crisis. New Haven, connecticut: Yale University. 1942 .

Radaliffe, G. II. .D. Govenor Hicks of Maryland and the civil war. Jolnns Hopkins University Series in Fistorical and Dolitical science. Ed. Irerbert B. Adam. Sertes vol. 19. Baltimore: Johns Hopking Unj.versity Press, 1901.

Randa11, J. Go Constitutional problens Under Iincoln. Gloucester, Massachusetts: Peter smith, 1965.

mammen-m. IshncoIn the President. 4 vol. Hev York: Doda. Mead CO. 1945-1255.

BandaI1, I. G. and Davia Donala. The Civil war and Reconstruction. 2d ed. Lexington, Massachusetts: D. C. Heath \& CO.g 1.969.

Raybacls, Robert I. Rillard Fillmore: Biography of a President. Buffalo: Buftalo fistorical Society. 1959.

Richardson, mester Dorsey. Sidelights on harym

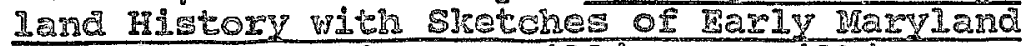

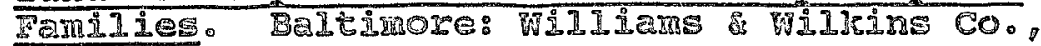
1913.

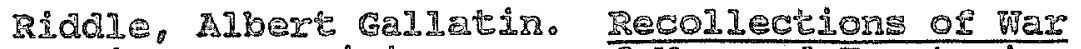

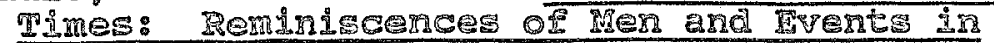

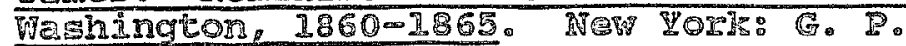
Petrina's SORE, 1395.

Ryan, Mary P. Crade or the MIddIe Class: The Tranily in onejoa County, Hew Yor? $1790-1865$. cambridge: Cambrage Univergity ses, 1981.

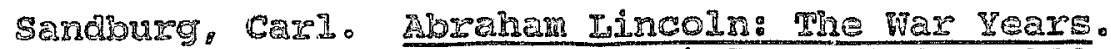
4 Vol:

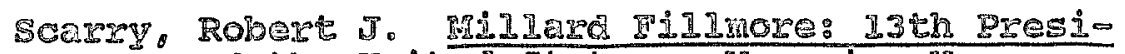
dent or the unitea States. Moravia, New

\$orT!: Robert J. Seary. 1282. 
Schmectulevier, Laurence $F$. History of the KnowNothing Party in Maryland. Johns Hopkins University series in Historical and Political Science. Ed. Herbert B. Adams. Series vol. 17. Baltimore: Johns Hopkins University Press: 1899 .

Schuckers, J. W. The Life and Public Services of Salmon portiand Chase, United states Senator and Governor of Ohio: Secretary of the Treasury, and Cnlas-Justies of the United States. New York: D. Appleton \& CO. 1874.

Scott, mne Firow. Making the Invisible woman Visible. Jabana, IIIInois: University of

TIIrrois DEass, 1984.

-n-m-m-m. The Southern Iady: From Pedestal to Politics, 1830-1930. Chicago: University of Chicago Press, 1970.

Scroggs, Filliam 0 . Filibusters and Financiers: The story of William Wralker and gis Associates. New York: Hacmillas CO. 1916.

Sears, Stephen W. Tandscape Turned Red: The Battle of Ancietam. New Haven, Connecticut:

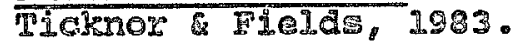

[Seaton, Josephine]. Wi1]iam Winston Seaton of the "National Intel Iigencer" Boston: James R. Osgood and company $187 \%$.

Setrescon, wiliam David. Formerly British HondGures: 2 Propla of the Mew Nation or Belize.

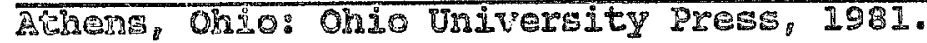

ShaIIsoge, Robert E. Sterling Erice: Portrait of a Southerner, Colubia, Missouri: University Of MISEOUY' Press, 1971.

SIIbeyp Joel H. The Partisan Immperative: The Dyrnamics of American politics Before the civil Wa: New Yoris: Oxford Undversity Press, i985.

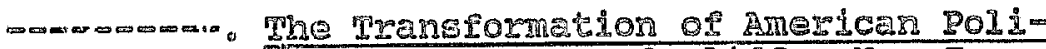
tics, $1940-1260$. Englemood Giffi, Nek Jersey: preatica-Ha11, 1967. 
Sklar, Kathryn Kish. Catherine Beecher: A Study in American Domesticity. New Haven, Connecticut: Yale University Press, 1973.

Staudenraus, $P$. J. The African colonization Movement, 1816-1865. New York: Columbia University press, 1961.

Stanton, Elizabeth C., Susan B. Anthony, and Hatilda JosIyn Gage, eds. History of Womars Suffrage. 6 vols. Rochester, New York: Susan B. Anthony, charles Mann, 1881-1922.

Steinex, Eernard Co Isife of Reverdy Johnson. Baltimore: Norman, Remington Co., 1914.

Stern, Madeline 圆, ed. Publishers for Mass Fntertaiment in Nineteenth Century America. Bostor: G. K. Hall \& CO., 1980.

stillwell, Lucille. John Cabell Brecirinridge. caldwe11, Idaho: the Caxtor Printers, 1936.

Tercentenary History of Haryland. Comp. Henry Fletcher Powell. 4 VOIs. Baltimore: S. I. clarke, 1925.

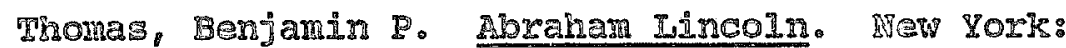
A1red Anope, 1952 .

Thomas, Berjamin $P$. and Harold Hyman. Stanton: The Ifie and Tines of Incoln's Secretary of

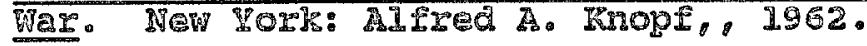

Thrall, Foner S. A Plctoriel mistory of Fesas. St. Louis: No D. Thomas \& Co., 1879.

Tretousse, H. T. Benjomin Franlah Wade: Radical Republican From Onio. IVew Yoxls: Trayne Publishers, 1963.

Pan Densen, GIyndon G. Thurnow Weed: Wizard of the Iobby. Boston: Little, Brom \& Co., 1947.

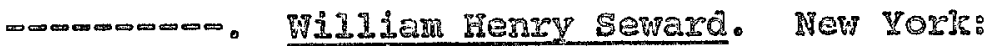
oxford บnมี

Fanger, Thomes Folmes. One runcired years of Hism cory, 1802-2002: A Reistory or the Secona Pres. 
byterian Church. Baltimore: n.p., 1902 .

West, Richard s., Jr. Mr. Lincoln's Navy. New York: Longmans, Green \& Co., 1957.

Wheaton, Henry. Elements of International Law:

The Literal Reproduction of the Edition of 1866 by Rahard Henry Dana, Jr. Ed. George Grafton Wilson. Oxford: Clarendon Press, 1936.

White, Franks If. The Governors of Maryland, 17771970. Annapolis: The Hall of Records Commission, 1970.

Whiting, william. The war powers under the constitution of the United States. Boston: 1.p. 1871: reprint ea., New York: Da Capo Press, 1972.

Williams, Kennetir B. Juncoln Finds a General. 5 vols. New Yorlx: Macmilian, 1949-1959.

Williams, T. Harry. Iincoln and the Radicals. Madison, wisconsin: University of wisconsin PLegs $_{\theta} 1962$.

WoLogn, Wancy. Women and the American gryperiance. New Yorts: Alfred Knopt, 1984.

Woodward, Ralph Le, I2. Central America: A Nation Divided. Hew Yors: Oxfora University Fress, 1976.

Wright, William cools. The Secession Movenent in the ridale atlantic States. Cranbury New Jersey: Associated UnIVersizy Presses, Inc, 1973.

Yowng, Fgatha. The Women and the crisis: Women of the North in the civil war. New Hork: MCDOwe11, Oblenstsy, 1959.

\section{Dissertation and Theses}

ramon, Judd Scott. "Suppress and Protact: The United states Navy, The Arrican SIave Trade, axd Marithe Comerce $1794-1862 . "$ Disserta tion, college of william and rary in virginia, 2978. 
Smith, Wilbur wayne. "The Whig Party in Maryland, 1826-1856." Ann Arbor, Michigan: University Microfilms, 1967.

Spencer, Jayme Ruth. "Abraham Iincoln and Negro Colonization: The Ile A'Vache, Hayti Experience, 1862-1864." Thesis, College of william and Mary in Virginia, 1971. 


\section{Curriculum vitae}

Janet Lee Coryel1. Born 12 October 1955 in Brolken Arrow, Olilahoma. B.A., State university college at cortland, Mev Yor\%, 1977. M.A., University of Dalaware, 1590. Frtered College of W11jan and rary, August 1982. Acmitted to Ph.D. candidacy. Hay 1934.

Ro. Coxyell has been a Lecturer at Butler county Community College, El Dorado, lnansas, and at Christopher Nerport College, Newport Newp, Vixgnia, She is ar Assistant Prosessor of ristory at the University of Dayton, Dayton, Ohio.

Publighed worlas:

"Robert E. Mey, John A. Quitnan, old South Crusader, in Southern Historian 7 (Spring 1986):58-59.

"Duty with Delicacy: Ama rila Carroll or Maryland, Forthcoming in Women and American roreign Policy: Lobbyists, Critics, and Insiders, edited by Edward D. Crapol (Greenwood Dress, spising 2937 publication). 